\title{
JUSTICE AND HUMAN RIGHTS IN THE \\ AFRICAN IMAGINATION
}

WE, TOO, ARE HUMANS

Chielozona Eze 
There is nobody more qualified to do justice to the imbrications of literature and ethical commitment in Africa than Chielozona Eze. With this well-accomplished and erudite book, Eze consolidates his position as the leading scholar of African ethics in literary contexts. Students and scholars of culture and philosophy will find this book an invaluable model for their own work.

- Cajetan Iheka, Yale University, author of Naturalizing Africa: Ecological Violence, Agency, and Postcolonial

Resistance in African Literature

Justice is often associated with an ideal state of affairs. Although this is an important way to approach the question of justice, realizing justice requires more than thinking about ideals. We must consider the aspect of what happens in situations where injustice is enthroned. This means to think about the damage done to individuals and social and political institutions due to the prolonged experience of injustice. Chielozona Eze offers in this book an outstanding study of these issues. He takes the reader on a journey that culminates in a clear understanding of the connection between political organization and the contexts of justice. Anyone interested in original ideas about justice, based on re-imagination of African conceptual resources, should read this book.

- Uchenna Okeja, PhD. Professor of philosophy, Rhodes University 

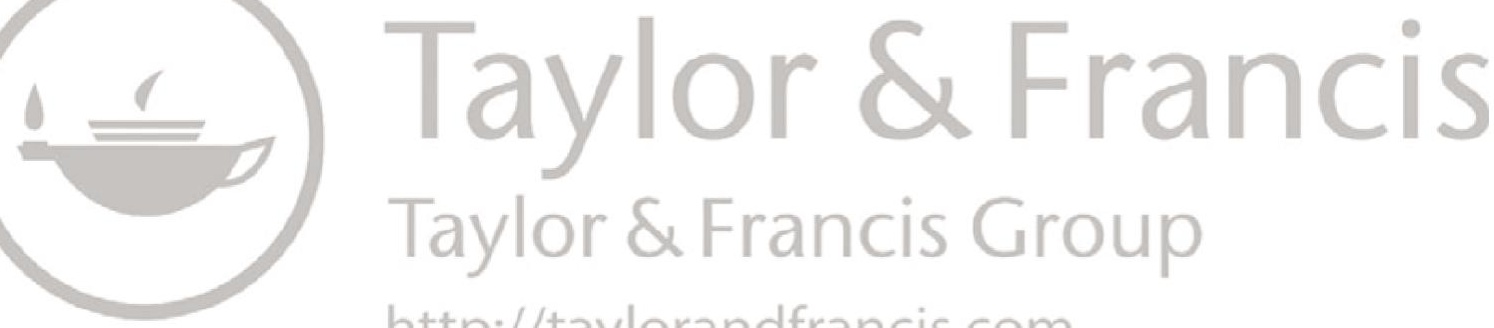

http://taylorandfrancis.com 


\section{Justice and Human Rights in the African Imagination}

Justice and Human Rights in the African Imagination is an interdisciplinary reading of justice in literary texts and memoirs, films, and social anthropological texts in postcolonial Africa.

Inspired by Nelson Mandela and South Africa's robust achievements in human rights, this book argues that the notion of restorative justice is integral to the proper functioning of participatory democracy and belongs to the moral architecture of any decent society. Focusing on the efforts by African writers, scholars, artists, and activists to build flourishing communities, the author discusses various quest for justice such as environmental justice, social justice, intimate justice, and restorative justice. It discusses in particular ecological violence, human rights abuses such as witchcraft accusations, the plight of people affected by disability, homophobia, misogyny, and sex trafficking, and forgiveness.

This book will be of interest to scholars of African literature and films, literature and human rights, and literature and the environment.

Chielozona Eze is a professor of African and African Diaspora Studies at Northeastern Illinois University, where he is Bernard J. Brommel Distinguished Research Professor. He is also Extraordinary Professor of English at Stellenbosch University, South Africa. He is the author of Race, Decolonization, and Global Citizenship in South Africa. 


\section{Routledge Contemporary Africa}

Higher Education and Policy for Creative Economies in Africa

Developing Creative Economies

Edited by Roberta Comunian, Brian J. Hracs and Lauren England

Decolonisation of Higher Education in Africa

Perspectives from Hybrid Knowledge Production

Edited by Emnet Tadesse Woldegiorgis, Irina Turner and Abraham Brahima

Everyday Crisis-Living in Contemporary Zimbabwe

Kirk Helliker, Sandra Bhatasara and Manase Kudzai Chiweshe

Media, Conflict and Peacebuilding in Africa

Conceptual and Empirical Considerations

Edited by Jacinta Mwende Maweu and Admire Mare

Gendered Violence and Human Rights in Black World Literature and Film Edited by Naomi Nkealah \& Obioma Nnaemeka

Justice and Human Rights in the African Imagination

We, Too, Are Humans

Chielozona Eze

The Literature and Arts of the Niger Delta

Edited by Tanure Ojaide and Enajite Eseoghene Ojaruega

Identification and Citizenship in Africa

Biometrics, the Documentary State and Bureaucratic Writings of the Self Edited by Séverine Awenengo Dalberto and Richard Banégas

For more information about this series, please visit: https://www.routledge.com/ Routledge-Contemporary-Africa/book-series/RCAFR 


\section{Justice and Human Rights in the African Imagination}

We, Too, Are Humans

Chielozona Eze 
First published 2021

by Routledge

2 Park Square, Milton Park, Abingdon, Oxon OX14 4RN

and by Routledge

52 Vanderbilt Avenue, New York, NY 10017

Routledge is an imprint of the Taylor \& Francis Group, an informa business

(C) 2021 Chielozona Eze

The right of Chielozona Eze to be identified as author of this work has been asserted by him in accordance with sections 77 and 78 of the Copyright, Designs and Patents Act 1988.

The Open Access version of this book, available at www.taylorfrancis.com, has been made available under a Creative Commons Attribution-Non Commercial-No Derivatives 4.0 license.

Trademark notice: Product or corporate names may be trademarks or registered trademarks, and are used only for identification and explanation without intent to infringe.

British Library Cataloguing-in-Publication Data

A catalogue record for this book is available from the British Library

Library of Congress Cataloging-in-Publication Data

A catalog record has been requested for this book

ISBN: 978-0-367-70854-2 (hbk)

ISBN: 978-0-367-70857-3 (pbk)

ISBN: 978-1-003-14827-2 (ebk)

Typeset in Times New Roman by codeMantra 


\section{Contents}

Acknowledgments $\quad$ ix

Preface xi

Introduction 1

1 Narratives and the common good 15

2 Ecological violence and the quest for justice 37

3 Mythic consciousness, witchcraft, and human rights abuses 63

4 Barriers to being: albinism, disability, and recognition 89

5 Intimate justice: homophobia and human dignity 109

6 Dignity of woman: from misogyny to sex-trafficking 136

Conclusion: politics of love and the common good 155

Index 165 

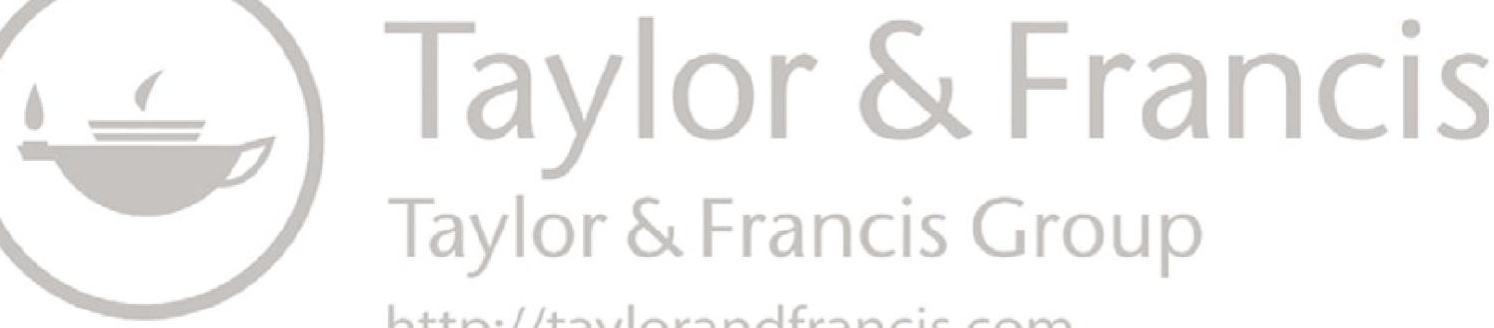

http://taylorandfrancis.com 


\section{Acknowledgments}

This book benefitted from my six-month residence at Stellenbosch Institute for Advanced Studies (STIAS) from July to December 2018. I have also profited from the discussions with friends and colleagues: Cajetan Iheka, Uchenna Okeja, Amatoritsero Ede, Paul Ugor, Uche Umezurike, Sister Mary Okolie, Dike Okoro, and Maik Nwosu. I am grateful to my fellow members of Northeastern Illinois University Genocide and Human Rights Research Group: Jeanine Ntihirageza, Alfred Frankowski, and Cris Tofolo. The congenial atmosphere in the English department and the friendship of my colleagues were enabling factors for the birth of this and other works. I am immensely grateful to my dear friend, Sangmin Bae, who first introduced me to some of the most important literature on human rights.

Northeastern Illinois University granted me a yearlong sabbatical leave to work on a different project. The first two months of the leave were devoted to this very work, and I am sincerely grateful to the President Gloria J. Gibson and the board of trustees. 

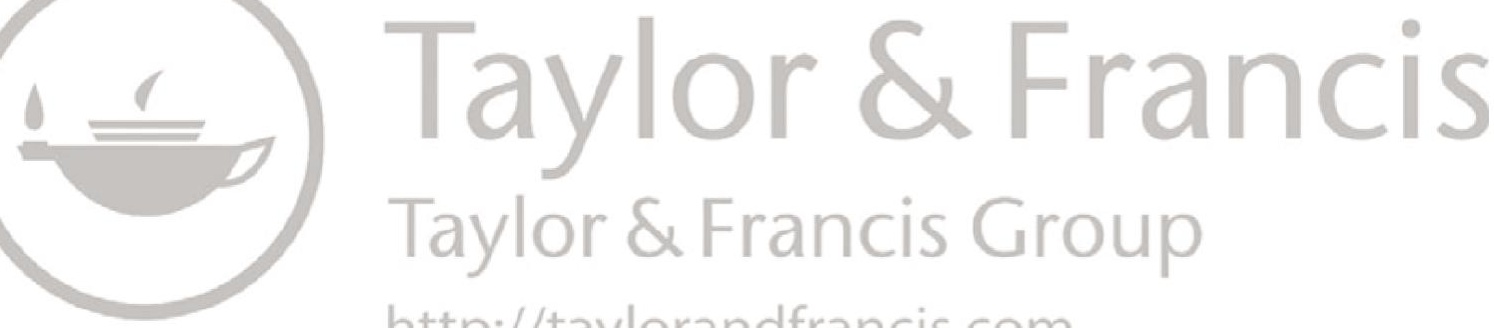

http://taylorandfrancis.com 


\section{Preface}

\section{What we talk about when we talk about justice}

To help me think through the notion of justice, I present two hypothetical situations, one of which is paraphrased from John Rawls's "Original Position."

First Situation: On the playground are five children-three boys and two girls - playing. A mother to one of them comes around, hands them five oranges, and tells them the oranges are for all of them. There are many scenarios that can ensue: They will share the oranges among themselves. I imagine the children holding a small conversation in which they establish the condition for sharing the oranges: "Everyone gets one orange each," the leader among them would say. "Yes, one person one orange," another would support. That would be the just thing to do. It would be fair. Another scenario is that one of them, perhaps a boy, could seek to have two oranges, claiming that he is hungrier than the others. What if he gives three of them one orange each and the fourth one gets nothing? Will the three speak up against the situation? What language would they use? What if the boys gang up and deny the girls their oranges because they are, well, girls? The girls object and ask: Why? The boys answer: You are girls, and, according to the bible, sin came into the world through women. Therefore, you must pay for your sins.

Second Situation: If, as embryos in the womb - ignorant of the conditions of our future lives, though capable of making decisions about the world-we were asked to imagine a society in which we all would be born, we would, for example, consider the situation in which we are born poor or with disability, or perhaps one in which we are born into wealth. But because we do not know the situation that awaits us, we would most likely strike a middle ground. Faced with a situation in which we are allowed to create an ideal society, we would most likely opt for a society of fair-minded people free of bias, because we might be in disadvantaged positions.

One of the things I take from Rawls's hypothetical situation is the power of the imagination in the dispensing of justice. If we are able for a while to put ourselves in the position of a person denied his or her due, and if we can 
see reality from that perspective even for a while, we might be compelled to rethink our attitude. Of course, the reality is that either most people are incapable of imagining reality from other people's perspectives or they refuse to do so, perhaps because their minds had already been conditioned by some narratives about the other. For example, racists refuse to imagine the racialized as deserving equal consideration as humans largely owing to the stories they have heard about these racialized others. The same applies to sexists. It is easy for a man to justify maltreating a woman because of the ancient tradition that drummed it into him that women are meant to occupy inferior positions in the family and in society.

The second part of the title of this book, We, Too, Are Humans, seeks to capture the voice of those who feel that they have not been treated the way humans ought to be treated: fairly. I imagine that if any of the children is denied an orange, he or she would ask: Why? Am I not a human being? The question, of course, assumes that every person deserves fairness on the ground of being human. My discussions in this book issue from this standpoint, from the perspective of those who perceived that their humanity had not been acknowledged by others, and their simple demand that they be treated like other humans are. It does not make any difference whether this demand is on the village playing ground, among five hungry children, or in the family among siblings regarding their parents' estates, or even between spouses, or between parties, villages, countries, tribes, ethnicities, and races. Every individual or group wants the same recognition accorded to others. The quest to be treated with fairness for the simple fact that we are humans constitutes the core of justice.

Most people associate the term justice with legal practices in the court of law and government ministerial positions like in the Department of Justice. I too have always done that by instinct. Without ignoring its legal ramifications, I approach the notion of justice from the bottom-up, from the perspective of being fair in our relations to others; fair in the distribution of respect, recognition, and material and intangible goods. A major concern in this book, therefore, is care about the pain we inflict on one another by the absence of fairness in our cultural, social, and political institutions, and in interpersonal relationships. Human rights abuses stem from the absence of care and a sense of fairness in our relation to others. I confine my discussions of human rights to the institutions closer to everyday people than to government apparatuses. In that regard, therefore, human rights is being fair in our quotidian interactions and in the social and cultural institutions that regulate them.

This book is conceived in part as an introduction to the conception of justice and human rights, and in part as a more nuanced discussion of issues that hinder human flourishing in Africa. I do not set out to provide a comprehensive theory of justice and human rights in Africa; rather, relying on a general understanding, I seek to make these concepts and issues obvious aspects of African discourse both in the academy and in society. 


\section{Introduction}

South Africa surprised the world not only with the relatively peaceful transition from apartheid to democracy but also with the choice not to follow the Nuremberg-type trial that would have rightly put behind bars those guilty of apartheid crimes. Some critics of the South African Truth and Reconciliation Commission (TRC) claimed that no justice was served. Archbishop Desmond Tutu, the chair of the TRC, however, proffered a vigorous defense of the commission's approach, arguing that it was indeed justice. It was just not the typical retributive model practiced in the West; it was restorative justice that is closer to the African reality. Restorative justice does not seek to punish the offenders; rather, it seeks to rehabilitate and reconcile them with the community. I share Archbishop Tutu's conviction that restorative justice is essentially African and essentially universal; justice is meant to restore the bond between individuals on the one hand, and on the other, between the individual and community. This view provides a prism through which to engage contemporary African reality.

It is fair to argue that the TRC was an extension of the philosophy and the moral character of Nelson Mandela who made ordinary virtues of love, forgiveness, generosity, empathy, and so on the guiding principles of his politics. Only they could restore South African people's appreciation of one another's humanity and therefore create a moral ecology that enables political success. I have argued elsewhere that Mandela tapped into the riches of empathy and other boundary-transcending virtues as a way to hold together and nourish the nascent multiethnic and multicultural society (Eze 2012). Indeed, Mandela understood that good politics and human flourishing are the two sides of any civic society that the post-apartheid society was aspiring to be. Only restorative justice, one that engages society from bottom-up, not the legalistic formulation characterized by retribution, can sustain such a society.

This book argues for the understanding of human rights from the perspective of restorative justice and well-being in Africa. To that end, I examine particular ways in which a new appreciation of human dignity, justice, fairness, empathy, and caring for others are hindered in the polis and how their calculated promotion could enhance human well-being. 


\section{Introduction}

One of the ways they could be promoted is through narratives understood as the construction of others in all forms of mythmaking and transmission of knowledge. More particularly, in this work, I focus on how these ideas are transmitted in African works of the imagination: fiction, poetry, and films. I pursue simple questions that I believe go to the heart of what it means to be human: What is the ethical content of the stories we tell about ourselves and others? How can a recalibration of those stories enhance life in society?

Many African scholars have grappled with the lingering effects of colonialism in Africa. Perhaps more still needs to be done in that regard. Thankfully, though, there has been an observable turn to a much-needed engagement with the African condition beyond the gaze of the West, a turn that engages with the many other issues besetting Africa, such as ecological violence, sex trafficking, homophobia, and attitudes toward people with disabilities. For example, Cajetan Iheka's (2018) celebrated book Naturalizing Africa: Ecological Violence, Agency, and Postcolonial Resistance in African Literature has opened a new vista for engaging the environment in Africa, especially in its emphasis on the bond between humans and the unknown. Humans are not the center of reality. Ato Quayson's (2007) Aesthetic Nervousness pays some attention to the issue of disability in Africa. There are now numerous articles that examine other issues that occupy the attention of Africans outside the gaze of the West, issues such as witchcraft accusations, ritual human sacrifice, neo-slavery, and women's right to their bodies. This development no doubt underscores the truth of Frantz Fanon's saying that each generation must, out of relative obscurity, discover its mission, fulfill it, or betray it. Thus, we admit that whereas the Chinua Achebe generation of African intellectuals rightly interrogated the image of Africa in the West, that is, how the West treated Africa, contemporary African intellectuals must interrogate the image of Africa in Africa. Rather than addressing an imaginary white man, they must focus on human well-being in Africa and how Africans can make it possible. Drawing attention to these issues and other human rights abuses and inspiring debate about them is not merely an academic exercise; discussing these issues, in my understanding, has life-and-death consequence. They are integral to our conception of the nature of society we want to live in and politics and democracy.

\section{Justice and human rights are about human lives}

Two unrelated incidents compelled me to start thinking about this book. First, in 2008, Tanzanian BBC journalist Vicky Ntetema exposed the outbreak of killings of people with albinism in Tanzania, the Democratic Republic of Congo, Burundi, and Rwanda (Ntetema 2008). The body parts of these people were harvested and used to prepare potions thought to bring good luck and wealth. Each time I thought about the condition of people living with albinism in Africa, I recalled Frantz Fanon's (2008) famous 
exclamations: “Maman, look, a Negro; I'm scared!” (91). Fanon’s words capture his feelings of being a black man, a stranger in Europe, in the early part of the twentieth century.

The second incident was in 2015 when Anja Ringgren Lovén, a Danish aid worker, saved a two-year-old Nigerian boy whose mother had left him on the street to die "because his family thought he was a witch" (Osborn 2016). This second incident needs more context to be fully appreciated. In 1876, Mary Slessor (1848-1915), a Scottish missionary, arrived in Calabar (Nigeria) for her missionary work. She was horrified by many aspects of the people's traditions, which included the killing or abandoning of twins because they were considered "children of the devil." The mothers of the twins were consequently ostracized. Slessor began to rescue and adopt the abandoned twins, help their ostracized mothers, and also enlighten the people in matters of the inviolability of human life and, by extension, of human rights. Coincidentally, Lovén saved the so-called witch boy in the part of Nigeria in which Slessor worked and died a century ago. Some troubling questions arise in the mind: What exactly has changed in the people's conception of human life and the dignity of the individual from 1876 to 2015? What have Nigerians failed to do regarding the inviolability of human dignity? Sadly, in some of these cases and others (discussed in Chapter 3), politicians and government officials are implicated in the belief system that breeds the abuse.

These two incidents are indisputable cases of abuse of human rights and dignity, some of which still find wide acceptance in many sectors of African societies. They raise questions of far-reaching implications for conceptions of justice in Africa. What is the value of human life in Africa? What are Africans to one another? If it is true that there is no meaning outside of narratives, or rather that we make sense of our lives by telling them, then what kind of stories do Africans tell themselves about themselves? What kind of society do Africans want? What do Africans owe one another in terms of human relationship? What are the criteria for determining what is right or wrong, who deserves respect or not, who gets what resources or enjoys what rights? These are the typical questions that concern justice in general.

Justice is obviously a legal and political term in liberal societies. Its best formulation is found in the American Declaration of Independence: All men are created equal and are endowed with certain unalienable rights, which include life, liberty, and pursuit of happiness. I am drawn to John Rawls's (1999) accessible explanation of justice. Two principles guide his notion of justice:

First: each person is to have an equal right to the most extensive scheme of equal basic liberties compatible with a similar scheme of liberties for others. Second: social and economic inequalities are to be arranged so that they are both (a) reasonably expected to be to everyone's advantage, and (b) attached to positions and offices open to all. 


\section{Introduction}

At the core of his theory of justice is the notion that justice is fairness, an idea he demonstrates with a thought experiment, called the "original position," and which I have sketched in the preface. This is a condition in which people are free, equal, and are able to make without bias choices about the principles that would guide their lives. For my purpose in this book, I rely on the notion of human dignity or the worthiness of individuals as the basis for justice. It states simply that every human deserves fairness because of their intrinsic dignity as humans.

Enlightenment philosopher Immanuel Kant states that "humanity itself is a dignity; for a human being cannot be used merely as a means by any other human being [...] but must always be used at the same time as an end" (Sensen 2011:174). As Oliver Sensen (2011) explains, Kant's theory about dignity does not state that "someone should be respected because he has dignity, but he has dignity because he should be respected" (74). The issue then is that being human alone earns every individual dignity and the right to be treated fairly. This right is anchored in our nature. This definition of dignity is also the origin of the thoughts about human rights, strictly understood as the concretization of justice.

There are certain levels of expectations of how we ought to relate and treat one another as members of human species. There might be variances across cultures and ages, but all people understand that being a human already grants you immunity from being eaten by other humans. It also presupposes that you be treated with some respect. Thus, when we say "We, too, are humans," we are referring to the implicit understanding that humans deserve to be regarded and treated in a certain way - at least better than animals and that this has obviously not been the case. The expression means that the above (Kantian) condition is not met, that others have either maltreated us or failed to accord us respect. By justice, therefore, I refer to the umbrella term that captures instances of the application of human dignity in our relation with one another. ${ }^{1}$

When we tell stories of people who have been treated unfairly by society, we do so to draw attention to the fact that they, too, are humans and therefore deserve better. We appeal to the common frame of being, to our dignity as members of the common specie. Yet, despite the noble position that we have granted to the dignity of all humans, we must admit that it is often a contentious issue in many societies that do not believe in the notion of the basic equality of all derived from Western thought. One might raise some questions, if only to play the devil's advocate: But must I treat others with respect? Must I exhibit fairness in my relation to others? Aren't we living in a competitive world in which the fittest survive? The answers to these questions are not obvious. I will address them in my discussion of the importance of the sense of the common good in Chapter 1. For now, though, it suffices to keep in mind the interplay between dignity, justice, human rights, and being human. 
Perhaps inspired by the Western notion of human dignity and the basic equality of all, most contemporary African writers are now more boldly questioning the cultural norms and the traditional narratives that control their lives, and they do so from the standpoint that we owe one another respect and fundamental fairness as humans. In the recent past, they have engaged with some of these issues, which had been somewhat ignored in the decades of anticolonial writings because of the perceived greater urgency of addressing imperialism and its manifestations in Africa. For example, whereas the first two generations of African writers and scholars might have defended African polygamy or female circumcision as part of African culture, contemporary African women authors write boldly about the psychological and physical pain of polygamy, spousal abuse, female genital mutilation, and so on. Some members of the contemporary African generation of writers tell about their alternative sexuality and the shame and pain their societies subject them to because of that; they write about the humiliating experiences of people living with albinism and so on. Indeed, they expose some cultural norms and ancient institutions as apparatuses through which injustice and unfairness are perpetuated in society. I interpret their writings as seeking to create moral frameworks within which human flourishing can be achieved in Africa.

Nigerian legal scholar Oche Onazi (2013) explains human rights in Africa as being basic to the community, a type of community that is itself constituted by expressions of love and empathy and forms of solidarity, cooperation, and collaboration. Bonny Ibhawoh (2018) demonstrates in his rich history of human rights in Africa that thoughts about justice and human dignity have been an important part of African history. Ernest N. Emenyonu's edited Politics \& Social Justice: African Literature Today (2014) provides a notable intervention in the conception of justice in African literature. Joseph R. Slaughter's Human Rights, Inc. (2007) and Elizabeth S. Anker's Fictions of Dignity (2012) are trailblazing in regard to the relationship between human rights and literature. Slaughter's discussion of the Bildungsroman makes a persuasive argument for the power of narrative to script human rights. James Dawes's The Novel of Human Rights (2018) focuses exclusively on the literature of the United States. Given their scope (global literature), these works understandably failed to pay adequate attention to the African contexts and other sources of knowledge production, especially regarding the contemporary African condition. ${ }^{2}$ Slaughter's and Anker's works emphasize the interplay between human rights discourse and law. My thinking about justice and human rights differs from the above in its exclusive emphasis on the moral implications of African narratives and cultural practices.

This book begins with the premise that all humans are endowed with immutable rights and shows how discussing specific African conditions can help drive home the necessity for comprehending justice and human rights 


\section{Introduction}

as not only universal but also beneficial for the mental and physical health of every individual. ${ }^{3}$ It also shows how the stories we tell can work against human rights and dignity. In all these, I approach justice and human rights from bottom-up, not the other way around. I mean that the issue of justice and human rights is placed in the hands of ordinary people, who through the activation of the virtues of empathy, tolerance, care, and solidarity create moral and legal frameworks designed to protect vulnerable members of society. In particular, I read the selected literary texts essentially as works of imagination that urge their readers to engage the known world and consequently begin the task of creating or heralding a world that is yet unknown. However, I do this in idioms familiar to philosophers, environmentalists, anthropologists, and human rights activists. This book, therefore, straddles literature, philosophy, film studies, and social and cultural anthropology.

\section{Justice, human rights, and the power of the ordinary virtues}

One of the reasons most Africans are reluctant to adopt the Universal Declaration of Human Rights (UDHR) is because the language of human rights is wrapped in legalisms, and its vocabularies have not yet shed their Eurocentric biases. Human rights is presented as sets of laws that are often imposed from above or ways of life promoted by NGOs, which are often cynically described as mercy-industrial complexes. The risk of this topdown rather than community-based approach to justice and human rights in Africa is that the notion of human rights remains alien to most African communities, even though respect for human lives has always been present in their midst. The top-down approach focuses almost exclusively on laws and governmental apparatuses and less on individuals, communities, and cultural institutions. On the contrary, the bottom-up approach, exploring the riches of intersubjective interaction and restorative justice, centers on basic moral assumptions of human rights and also raises people's awareness of the gratuitous pain that other people's words, actions, decisions, and cultural or religious practices can inflict on others. Additionally, the community approach to human rights sharpens awareness of the humanity of others and highlights the riches of mutual trust and affirmation and seeks to make individuals aware of their responsibility in the proper functioning of their community.

Michael Ignatieff argues that the UDHR is a juridical revolution that has touched nearly every part of the world. He acknowledges Eleanor Roosevelt's immense contribution to that, especially in her belief that the place for the realization of the revolution is "in small places, close to home-so close and so small that they cannot be seen on any maps of the world" (Horton 2007). Thanks to the Declaration, people now have more ways to articulate their voices when they feel that they have been denied justice. Ignatieff argues that "the privileges that were once attached to race, gender, and religion may not be gone, but their moral authority is contested at every turn. 
This is the great achievement of Mrs. Roosevelt's revolution" (Ignatieff 2017a:6). In many instances, though, human rights discourse seems to have become fixated on the easily measurable external metrics of progress. These metrics include whether many states have ratified the Declaration and whether instances of gross human rights abuse have decreased. It has also become part of the assumption that human rights conventions, once adopted and ratified, "have some influence on the 'ordinary virtues' - that is, the common practices of trust and tolerance, forgiveness and reconciliation that are the essence of private moral behavior" (2017a:4). Indeed, many people believe "that human rights remains an 'elite discourse,' a language spoken by lawyers, advocates, victims' groups, and bureaucrats - not by a wider public at large." Yet what they truly respond to, Ignatieff argues, is the language of the ordinary virtues rather than that assumed by the Universal Declaration. To be sure, Mrs. Roosevelt did not deny the necessity of the universal language of the Declaration and the activism that helps keep it alive. The metrics of its success, as Ignatieff suggests, should not be defined exclusively in terms of activism or the political sector of the human rights revolution.

Ignatieff finds a chasm between the language of the Universal Declaration and the ordinary virtues, between local and universal, the citizen and the stranger. He states:

Human rights enjoins us to be tolerant, to recognize the universal equality in all human beings. From an ordinary-virtue perspective, on the other hand, human beings do not appear clothed in what Marx called "species being." Ordinary virtue accepts no general obligation to tolerate anyone. Its motto is "Take people one at a time."

(Ignatieff 2017b:212)

In his apparent dismissal of the universal claim of the UDHR, Ignatieff seems to propose a narrow sympathy, implying that we care only about those we know and that the locals do not care about universals or about what happens to others not related to them. ${ }^{4}$ This may not paint the entire picture of humans as essentially moral beings.

It is true that we care primarily about those we know and that we cannot enforce human rights the way a state enforces its laws, but it is also true that humans care about the fate of others they do not know, provided that they are made adequately aware of that fate and the people. We cannot care about those we do not know, but that is also why we tell stories, as narratives bring us closer to strangers. Because of their nature as moral beings, and thanks to the virtues of narratives, humans are also wired toward the pursuit of the common good. ${ }^{5}$

We can abandon neither the universal aspiration of the UDHR nor the activism that helps drive it to the farthest reaches of the earth, and nor can we ignore the roots of the Declaration in ordinary virtues and the common 


\section{Introduction}

good. I suggest that narratives provide a model for bridging the gap between the universality of human rights aspiration and the concreteness of ordinary virtues. Thus, narratability becomes a test of the universal nature of concrete rights. ${ }^{6}$ Elizabeth Swanson Goldberg and Alexandra Schultheis Moore (2012:2) argue that stories "render intelligible the philosophies, laws, and practices of human rights from multiple, shifting cultural perspectives." Expressed in simpler terms, to know whether any aspect of the UDHR or justice in general can be grasped by those to whom ordinary virtues mean something, we ask: Can it be told in stories? Stories connect the man in a Nigerian village not only with another man or woman in the same or the next village but also with another man or woman thousands of miles apart on a different continent and of a different race. Narratives link ordinary virtues and our interdependence on one another and therefore underline the absolute necessity of universal moral frameworks such as respect for other lives and caring for the vulnerable. ${ }^{7}$

It must be noted that narratives can be double-edged swords. Although they can elevate the dignity of the others, they can also be used to render the same others as strangers; this aspect will be discussed further in Chapter 3. So, we must establish the kind of narrative that leads to awareness and promotion of justice and human rights (Chapter 1). Mencius, a great moral teacher who is best known for giving Confucianism its most profound philosophical grounding, is said to have narrated an incident about a child who was about to fall into a well. Mencius states, "Suppose a man were, all of a sudden, to see a young child on the verge of falling into a well. He would certainly be moved to compassion" (Mencius 1970:82). Why did he tell this anecdote? Why did Jesus Christ tell the parable of the Good Samaritan? Why does a writer tell the story of a person living with albinism in Africa and who feels shame and insecurity because of his "whiteness" in a land of black people?

I understand that the above anecdotes are read in religious or purely philosophical contexts and may thus not count as typically literary in the same way as contemporary African novels do. Whereas the reasons for Jesus's and Mencius's anecdotes are well known, I think the writer of modern literary fiction that addresses the human condition, or anthropologists who conduct research and relate their observations, engage in no less a morally noble task, albeit in a much more complex format that inspires a more expansive examination of reality. Admittedly, literary fiction is more of an inquiry than are parables. Above all, literary fiction, focusing on the human condition, leads to the appreciation of the everyday practice of ordinary life and thus of the richness of ordinary virtue. Ultimately, the issue I pursue here is how African narratives, including works in social and cultural anthropology, testimonies, and cultural texts, bring about a rethinking of what the South African philosopher and literary scholar Njabulo Ndebele (1986:156) characterizes as the rediscovery of the ordinary - that is, the fundamental interpersonal relationship. I examine the way Africans live and relate to one 
another and how African stories enable this relationship and engender or hamper human rights, happiness, and well-being in African communities.

Well-being is understood as the state of doing well or being happy. It is generally understood as an extension of the Greek notion of eudaimoniahuman flourishing or prosperity. It occupies a central place in Aristotle's (1999) philosophy and refers to the highest human virtue, a condition for living a life of enduring happiness and fulfillment. Human flourishing also refers to the condition in which every individual achieves optimal welfare in freedom; it is also a condition of belonging to communities, helping others, and benefiting from them in ways that are also captured by the southern African concept of ubuntu. More precisely defined, it concerns the condition in which all people live in dignity, equality, freedom, and respect for bodies as they are. In this book, therefore, I use well-being and human flourishing interchangeably to denote the condition of a good life marked by happiness and self-fulfillment, guided by the awareness and the pursuit of the common good. Expressed in the spirit of human rights, it is a condition in which society respects every individual's dignity and moral sphere. ${ }^{8}$

Narratives do not automatically become moral inquiry or create moral frameworks because they tell moral tales. One thing is certain, though: They make the abstract notions of right or wrong concrete. As Jean-Paul Sartre (1988:27) puts it, they disclose a world and make it easier for us to engage with it and make a decision. For instance, if a story tells us how a European multinational company dumped highly toxic waste in some corners of Africa after the waste had been rejected in Europe, the reader of this account might feel that something is not right. If the story then goes on to show in detail how, for example, a woman gave birth to a malformed child, the reader's judgment is further enhanced. The story does not need to make a judgment. The reader does. ${ }^{9}$

Literature is not interested in engaging in the abstract notion of good and evil the way philosophy does; it shows the reader an aspect of people's choices, especially in relation to other people's lives. In this regard, narrative allows us to view the features of human actions through a microscope and urges us to ask questions about our humanity and the moral frameworks that guide it. ${ }^{10}$ Sartre puts it well when he states that "although literature is one thing and morality a quite different one, at the heart of the aesthetic imperative we discern the moral imperative" (67). To write about the human condition is to make human lives available for judgment.

For African literature to be read as an inquiry or as capable of highlighting the riches of ordinary virtues, therefore, it must take the African body seriously, and it must believe in African moral agency. It must engage with questions such as: what is the African body to another African? What are Africans to one another $?^{11}$ Any story that arises out of these conditions, therefore, challenges all to respond - that is, to take a position either for or against the life and dignity of persons involved. Every decision is further weighed on the scales of right and wrong, acceptable and not acceptable. 


\section{Method and structure}

Given the interdisciplinary nature of this book, I have strived to pay equal attention to philosophical, literary, and socio-anthropological texts. As a philosopher and literary scholar, however, I find my discussions filtered heavily through philosophical prism. I can only hope that the reader grants me this indulgence. The literary works discussed here are not representative of the immense range of the corpus of African literature. I have discussed many of them in Ethics and Human Rights in Contemporary Anglophone Women's Literature, with emphasis on feminist issues. The justice and human rights arguments I map out here-that is, my emphasis on the notions of dignity, the common good, and human flourishing - can with some nuance apply to most works not represented here. Of acute importance for me is the content and quality of a society's relation to its individuals and individuals' relationship to one another.

The decisive factor in my choice of literature is the degree to which these works underline the importance of reading African texts that show a new understanding of justice and global issues such as ecological violence, gender violence, prejudice against those with albinism, and homophobia. My interest in films here is restricted to those produced in Nigeria over the past twenty years and which go by the evocative name "Nollywood." Some of these films have been identified as promoting the abuse of human rights through their glorification of witcheraft and human ritual sacrifices. Watching these films raises important questions about the relationship between ethics and aesthetics, especially regarding human rights. The films achieve the exact opposite of what the other texts do, and that draws critical attention to their role in shaping society's moral sentiments. I compare the Nollywood films with one of the aesthetically and ethically more satisfying films, namely I Am Not a Witch, also on the same topic.

This book is divided into two thematic sections: (a) justice and the environment and (b) mythic consciousness and the (de)construction of difference, and intimate justice. The first is fairly straightforward. The second is broad and more complex, and in it, I explore the moral implications of the attitudes toward various markers of difference in African societies, such as color (albinism), gender, ethnicity, "child witches," and homophobia. I examine in particular how the narratives around these markers of difference shape people's relationships with other humans to whom these markers apply and their implication for social and intimate justice.

The chapters are arranged to make the linear argument that the concern for our environment leads to concern for oneself, for the other, and finally for the well-being of community and society. Chapters 1 and 2 center on the environment of human rights, conceived in physical and moral terms. Chapters 3 and 4 center on social justice and examine the structure and implications of mythic consciousness on human rights. Chapters 5 and 6 focus 
on intimate justice and are concerned with the violence of normativity. They consider in particular the violence of categorization in regard to heterosexuality and its implications within a given patriarchal order.

The central goal of Chapter 1 is twofold: First, it establishes the need for a strong moral framework and the pursuit of the common good in society and that justice forms the centerpiece of that. The second purpose is to show that narratives help us establish the idea of the common good. Narratives appeal to an imagined community that abides by universal frameworks. Furthermore, this chapter breaks down the language of human rights in idioms that can bring their universal ideas closer to the African reality.

Chapter 2 presents the argument that awareness of the fragility of our environment and human life are the two sides of the same coin of the human condition. The argument of this chapter is structured in three steps: (a) I discuss the environment as an integral part of the common good and a moral responsibility for all; (b) I analyze the sociocultural philosophy of Wangari Maathai, Africa's preeminent environmentalist and Nobel Peace Prize winner. I discuss her conception of the environment as a vital part of the common good; and, finally (c) I trace the colonial mindset that guides the relationship between developed and developing nations concerning ecological violence. Against the backdrop of the above issues, this chapter analyzes how African writers position ecological violence as a human rights issue. I focus in particular on how Nigerian writers and activists such as Gabriel Okara, Tanure Ojaide, Ogaga Ifowodo, Nnimmo Bassey, and Helon Habila responded to the ecological catastrophe caused by multinational oil companies in the Niger Delta.

Chapter 3 establishes how mythic consciousness creates the phenomenon of witchcraft in Africa and how the phenomenon hampers awareness and promotion of human rights. The goal of this chapter is to show how stories (myths) can be abused, that is, used to block people's portals of empathy. I work from the premise that the respect people have for one another and for strangers is correlated to the image of the human person in their stories.

Chapter 4 enhances the notion of mythic consciousness and discusses the major humanistic challenge that people with albinism face: barriers to being. In most countries in sub-Saharan Africa, people with albinism are viewed as not just different; in some cases, they are murdered, and their body parts harvested for ritual purposes. Very few narratives have engaged this issue. With the support of ample anthropological evidence, I discuss three fictional narratives: Jenny Robson's Because Pula Means Rain, Tara Sullivan's Golden Boy, and Petina Gappah's The Book of Memory. I analyze the African world from the perspectives of characters with albinism and employ Frantz Fanon's postcolonial theory to shed light on this condition.

The central concern of Chapter 5 is how the African body is seen as the theater of religious and cultural politics, thus rendering it easy to violate people's intimate space. I focus specifically on the bodies of the members of the LGBTQ community. For instance, in many African countries, gays and 


\section{Introduction}

lesbians are seen as imitating a decadent Western lifestyle and are therefore corrupting Africa. They are thus subjected to different forms of humiliation, including corrective rape and murder. Countries such as Uganda and Nigeria have enacted laws banning "homosexual activities." Since then there have been numerous cases of violence against gays and lesbians. This chapter analyzes selected poetry from the LGBTQ community, the documentary film Call Me Kuchu, and Chinelo Okparanta's novel Under the Udala Tree.

In many instances, women are seen only through the prism of utility, all in the name of tradition or maintaining the community's survival. Chapter 6 discusses the attitudes toward women that see them as means to society's ends and how these attitudes often morph into outright enslavement of women. It discusses three novels: Adeyemi Adebayo's Stay with Me, Buchi Emecheta's The Joys of Motherhood, and Mariama Bâ's So Long a Letter.

The conclusion is a meditation on forgiveness as a fundamental aspect of restorative justice. Focusing on Pumla Gobodo-Madikizela's memoir, $A$ Human Being Died That Night, I discuss how the testimonies deposed before the TRC provide good examples for our understanding of the power of narratives to demonstrate the imbrication of justice, ordinary virtues, and the common good.

\section{Notes}

1 I shall be using the terms human rights and social justice as concrete manifestation of the more abstract term, justice.

2 To be sure, Anker's discussion of J. M. Coetzee and Nawal El Saadawi is as African as it gets.

3 It also admits that despite the claim to the universality of human rights, not all cultures or societies subscribe to its assumptions. For example, in their Charter on Human and People's Rights, African nations sought to temper the universality of the UDHR and its focus on the individual with their emphasis on people's rights. See African Commission on Human and Peoples' Rights, "African Charter on Human and Peoples' Rights," http://www.achpr.org/instruments/ achpr/\#a29.

4 I address Ignatieff's rich but controversial opinion further in Chapter 1.

5 This also underscores the moral assumptions of the South African TRC, which highlighted the importance of personal and community testimonies. These testimonies did not rely on the force of law but on the possibility of rediscovering people's common humanity by narrating their experiences for ready ears.

6 By narratability, I mean the ability to put in credible story form relevant values or ideas about the human condition.

7 I will explore this in greater detail in Chapter 1.

8 I understand that the notion of happiness has been tainted by the American understanding, which seems to suggest greed and rugged individualism. My uses of the concept are far from this. Indeed, it might even be seen as its opposite. I take into consideration the individual's awareness of the common good and the consequence of one's actions on others and the community. It also implies that community must not stand in the way of an individual's moral space.

9 I admit that the judgement is not a given. Readers do not react in the same way to particular stories. 
10 For literature to be read as moral inquiry or as capable of creating moral frameworks, instances of right or wrong have to be signaled; narratives have to relate to an issue in the public consciousness and therefore urge people to respond. There are many ways a narrative can thrust issues into the public consciousness, one of which is what a character does, says, or wishes; it is simply the experience of a character. Once an issue is suggested by attention to the character's experience, there has to be complex interpretation, which includes attention to language, style, and other techniques employed in literary production. I will flesh out this thinking in Chapter 1.

11 These are, of course, the universal questions that underwrite every ethical inquiry.

\section{References}

Anker, Elizabeth S. 2012. Fictions of Dignity: Embodying Human Rights in World Literature. Ithaca, NY: Cornell University Press.

Aristotle. 1999. Nicomachean Ethics. Translated by Terence Irwin. Indianapolis, IN: Hackett Publishing Co.

Dawes, James. 2018. The Novel of Human Rights. Cambridge, MA: Harvard University Press.

Emenyonu, Ernest N. ed. 2014. Politics \& Social Justice: African Literature, vol. 32. Rochester, NY: Boydell \& Brewer Inc.

Eze, Chielozona. 2012. "Nelson Mandela and the Politics of Empathy: Reflections on the Moral Conditions for Conflict Resolutions in Africa." African Conflict \& Peacebuilding Review 2 (1): 122-135.

Fanon, Frantz. 2008. Black Skin, White Masks. Translated by Richard Philcox. New York: Grove Press.

Goldberg, Elizabeth Swanson and Alexandra Schultheis Moore. 2012. Theoretical Perspectives on Human Rights and Literature. New York: Routledge Press.

Horton, Scott. 2007. "Roosevelt on Human Rights in Small Places.” Harper's Magazine. https://harpers.org/blog/2007/12/roosevelt-on-human-rights-in-the-smallplaces/ (Accessed September 12, 2020).

Ibhawoh, Bonny. 2018. Human Rights in Africa: New Approaches to African History. New York: Cambridge University Press.

Ignatieff, Michael. 2017a. "Human Rights, Global Ethics, and the Ordinary Virtues." Ethics \& International Affairs 31 (1): 3-16.

Ignatieff, Michael. 2017b. The Ordinary Virtues: Moral Order in a Divided World. Cambridge, MA: Harvard University Press.

Iheka, Cajetan. 2018. Naturalizing Africa: Ecological Violence, Agency, and Postcolonial Resistance in African Literature. Cambridge: Cambridge University Press.

Mencius. 1970. Translated by D. C. Lau. London: Penguin Classics.

Ndebele, Njabulo S. 1986. "The Rediscovery of the Ordinary: Some New Writings in South Africa.” Journal of Southern African Studies 12 (2): 143-157.

Ntetema, V. 2008. "In Hiding for Exposing Tanzania Witchdoctors." BBC News, July 24. http://news.bbc.co.uk/2/hi/africa/7523796.stm (Accessed September 12, 2010).

Onazi, Oche. 2013. Human Rights from Community: A Rights-Based Approach to Development. Edinburgh: Edinburgh University Press.

Osborne, Samuel. 2016. "Two-year-old Nigerian Boy Accused of Being a Witch Rescued by Aid Workers." Independent, February 15. http://www.independent.co.uk/ 


\section{Introduction}

news/world/africa/two-year-old-nigerian-boy-accused-of-being-a-witch-rescuedby-aid-workers-a6875706.html (Accessed July 10, 2018).

Quayson, Ato. 2007. Aesthetic Nervousness: Disability and the Crisis of Representation. New York: Columbia University Press.

Rawls, John. 1999. A Theory of Justice. Cambridge, MA: The Belknap Press of Harvard University.

Sartre, Jean-Paul. 1988. What is Literature? And Other Essays. Cambridge, MA: Harvard University Press.

Sensen, Oliver. 2011. Kant on Human Dignity. Berlin: Walter de Gruyter.

Slaughter, Joseph, R. 2007. Human Rights Inc.: The World Novel, Narrative Form and International Law. New York: Fordham University Press. 


\section{Narratives and the common good}

The fact that the notion of human rights is abstract and in many cases contentious is very much known. Different cultures and societies conceive of it in different ways. For example, most Africans associate it with Western moral imperialism and specifically with nongovernmental organizations headquartered in New York, London, or Paris. Human rights, they believe, is not original to Africa. Yet when confronted with the granular details of the contents of the Universal Declaration of Human Rights (UDHR), they admit that human rights is as African as African people's respect for their elders and neighbors. What, then, accounts for the apparent disconnect between the noble aspirations of the UDHR and their instantiations in people's lives?

Africans are not alone in this apparent mistrust of aspects of the human condition. Cynicism toward human rights is widespread in the West. Former leader of the Liberal Party of Canada Michael Ignatieff (2017a:4) does not believe in the universal claims of the Declaration either; rather, he proposes ordinary virtues as a better alternative, and, for him, ordinary virtues mean "the common practices of trust and tolerance, forgiveness and reconciliation that are the essence of private moral behavior." In June 2013, he led a small team of moral inquirers on a journey of discovery, which took them to four continents, specifically to villages, shantytowns, favelas, and poor neighborhoods, where they interviewed citizens and dwellers about their views of the world and human rights. He states that the most outstanding feature in the expression of morality among the people he interviewed is how little the people used the universal principles of any kind to justify their relationship to their fellow humans. On the contrary, "they reasoned in terms of the local, the contingent, the here and now" (Ignatieff 2017b:208). Rather than organize their moral life according to abstract principles of justice, or imagining "the human race beyond the veil of ignorance [...they imagined] themselves: their own reflection in the mirror" (208). It is as difficult to disprove this observation as it is to believe that humans do not care much about other humans outside their immediate circle.

In light of the above, I wonder whether we can truly manage our increasingly complex world without recourse to some idioms that transcend the 
idols of the tribe, idioms rooted in universality. I duly acknowledge the African (and postcolonial) mistrust of the discourse of universality because of its provenance in Western modernity. However, I argue that we also need universals, even while holding on to the virtues rooted in the world we know. How then can we bridge the gap between the grandiose language of justice and human rights and its practical relevance to people's lives? How do we explain to an average African that accusing his or her neighbor of witcheraft is unjust and a gross abuse of the other's human rights and that this other deserves those rights because he or she has intrinsic dignity as a human being, a universal property?

I think it is safe to say that any proper understanding of universal human rights must take into account its origins in the ordinary virtues of co-feeling, care, tolerance, and so on. This much is obvious in the many versions of the history of human rights in Europe. For example, Lynn Hunt (2007:34-39) argues that eighteenth-century European sentimental novels such as JeanJacques Rousseau's Julie or the New Hélö̈se and Samuel Richardson's Pamela (1740) and Clarissa (1747-1748) provoked a "torrent of emotions" and co-feeling in their readers because of the way they shed light on the pains of their protagonists and so contributed to the thoughts captured in the proclamation of "the rights of man." Ultimately the notion of empathy, this most basic of the ordinary virtues, was an integral part in the thinking about universal human rights. As Hunt states,

novels made the point that all people are fundamentally similar because of their inner feelings, and many novels showcased in particular the desire for autonomy. In this way, reading novels created a sense of equality and empathy through passionate involvement in the narrative.

Even before the eighteenth century, stories have always been a reliable means to appeal to people's sense of solidarity, as I have already implied in my references to Mencius and Jesus. It is therefore worth posing the question: What can thoughts about justice and human rights in Africa learn from narratives about African lives?

I seek to achieve two main things in this chapter: First, establish the absolute importance of universal moral frameworks for the existence of decent societies and participatory democracy in Africa, and second, show how narratives can bring us closer to those moral frameworks, part of which is the notion of human rights. UDHR and all the subsequent Conventions and Covenants gesture toward universal moral frameworks that imagine all nations (indeed, all societies) as parts of a community. When people describe their conditions as threatened, they appeal to that community in the knowledge or assumption that all are bound by the frameworks that make us what we truly are as humans. As Kay Schaffer and Sidone Smith (2004:3) argue about life narratives in the context of human rights, "In the specific locales 
of rights violations and in the larger court of public opinion, life narrative becomes essential to affect recourse, mobilize action, forge communities of interest, and enable social change." What they recognize as the larger court of public opinion, I call universal moral frameworks and which I understand further down within the context of the common good. In pursuit of these goals, I break down human rights in the idioms of ordinary virtues that are an essential part of African people's lives, as surely they are a part of lives elsewhere.

\section{Stories, values, and the community}

James Dawes, the founding director of Human Rights and Humanitarianism at Macalester College, has observed that literature and human rights have increasingly gained attention in world literature. Much of that attention had been devoted to "ideology critique and moral normativization. Critics have framed texts by way of ethical paradoxes inherent to the broader human rights movement itself" (2018:4). I think such critiques are in order when dealing with developed societies of the West, which have some degree of ethical and legal standards. ${ }^{1}$ The human rights situation in Africa and, perhaps increasingly in the West, given the growing coarseness of society, requires a return to the basis of society's moral framework. After the end of apartheid, South Africa was faced with the colossal but fundamental and delicate task of demonstrating the humanity of all, despite the horrors of the past. The task was all the more complex because the colonial and apartheid systems had never granted black people that basic affirmation. On the other hand, it appears to be impossible to expect black people to extend equal humanity to those who had brutally oppressed them for centuries.

It is perhaps part of Nelson Mandela's ingenuity and boundary-defying legacy that his government came up with a simple idea of people telling one another their stories of suffering in the now famous Truth and Reconciliation Commission (TRC). The goal of the TRC was to provide a new context for understanding justice; it was to create a condition for restorative rather than retributive justice. It was to restore the humanity of all, the oppressors and the oppressed. As Dawes (2009:395) has observed, "The TRC was arguably one of the most visible acts of collective storytelling in the history of human rights endeavors... It was quite self-consciously an exercise in narration and healing." The TRC did not bring about a perfect peace or economic progress or the acceptance of the humanity of all South Africans. Its greatest achievement, though, was the creation of moral frameworks that would make the pursuance of those goals worthwhile and credible.

In his justification of the modalities of the TRC, Archbishop Desmond Tutu (1999:26) states: "Since we were exhorted by our enabling legislation to rehabilitate the human and civil dignity of victims, we allowed those who came to testify mainly to tell their stories in their own words." Archbishop 
Tutu alludes to the special atmosphere surrounding the ritual of testimonies. The TRC created special context and condition that gave the victims the feeling of being taken seriously. The victims felt readmitted into the universal humanity. Of importance is Tutu's interpretation of the humanistic reach of the mandate given to them. He underlines what he believes has been one of the immediate results of such an exercise when he relays the testimony provided by one of those who had told about their ordeals during apartheid. According to Tutu, the man said:

Archbishop, we have told our story to many on several occasions, to newspapers and to the TV. This is the first time though that after telling it we feel as if a heavy load has been removed from our shoulders.

I read the man's metaphor of a heavy load being removed from his shoulders as a feeling of not only relief but also of becoming whole and being a member of the human community. I think it is fair to suggest that the man felt that justice has been served. ${ }^{2}$

Based on Archbishop Tutu's testimony, it does appear that the ordinary act of narration links one's humanity to that of others in society. It makes people, ordinary people, feel their mutual reliance on one another. Their dependence is not economic, social, or political; it is moral and to the degree that it helps people to appreciate their own dignity and that of others. We note in the man's testimony the special context in which a heavy load has been removed from his shoulders. The context is the gathering of the community as distinct from an audience of one journalist. The gathering of the community recalls the origins of storytelling in the caves and small groups in the tribe, situations in which people told stories in order to live, as Joan Didion (2006) suggests. Every story assumes a community so that there is a special bond between the individual (the narrator) and the community (the listener). Commenting on Desmond Tutu's reading of the testimonies of the TRC, Eleni Coundouriotis (2006) argues that how one understands dignity affects how one perceives political struggle and social and political power. It does appear, therefore, that Tutu interprets dignity first and foremost as being fully integrated into the human community. His whole political struggle has been the creation of a rainbow community.

What is communicated in the narrative act is the awareness of the moral presence of the others in our lives; that is, with the stories come the virtues of compassion, care, a common search for truth, and some shared sense of justice. Tutu makes a rigorous distinction between the type of justice that is communicated through the TRC, which is restorative, and the conventional Western understanding of the same, which is retributive. Dignity is integral to our understanding of human rights and belongs squarely in the sphere of restorative justice. What is restored is precisely what had been denied: the sense of worth. This understanding of dignity, highlighted in the preamble 
to the United Nations' Universal Declaration of Human Rights (UDHR), is enhanced when approached from the South African notion of $u b u n t u$, which I discuss in the later part of this chapter.

As much as every society needs legal frameworks to assure that people's dignity and rights are not trampled upon, laws cannot initiate or sustain these virtues in people; they must be initiated in interpersonal relationships outside the reach of laws. As Eleanor Roosevelt states, human rights and dignity must be sought "in small places, close to home" (Horton 2007). Human rights are therefore approached from the bottom up, not the other way around. Its approach emphasizes ordinary virtues, and it is in light of the ethical and human rights impulses of the TRC that this book examines the role of narrative in the promotion of justice and human rights in Africa. It asks: What is the relationship between the stories we tell about ourselves and others and the dignity we accord humans? What is the image of the human person in the stories we tell?

Literature is about the stories we tell. We do so for many reasons, some of which include entertainment, keeping ourselves company, and imparting lessons that could be religious, moral, or mundane. Sociologist Arthur W. Frank (2010:46) argues: "Stories teach people what to look for and what can be ignored; they teach what to value and what to hold in contempt." Frank's claim is true based alone on the material we select for our stories; every choice of material reveals the value system of the person who makes that choice. Also, the way a story is arranged-what is highlighted and what is suppressed-says much about what is important and what is less so. Through a subtle and often complex system of figures, signs, and symbols, stories thus shape our values and display our moral dispositions to the world.

Walter Fisher (1984:6) argues that regardless of the form our stories take, the primary thing in storytelling is "to establish a meaningful life-world." There will be differences in character, conflicts, and so on, "but each mode of recounting and accounting for is but a way of relating a 'truth' about the human condition." What is at stake here is the human community. Who deserves to stay in? Who is to be excluded? A person who tells about his pain wants that experience to be taken seriously. He or she wants others to feel what he or she has felt, if only vicariously. The assumption of co-feeling suggests the desire of the narrator to be welcomed into a world, out of which his or her experience of pain had forced him or her. He or she wants to know that he or she, too, is human.

At the most obvious and perhaps more immediately and ethically rewarding level, stories provide us with characters whose mere existence excites our curiosity and, when translated into everyday encounters, reads like the questions we might pose to a stranger: Who are you? What is your name? Where are you from? What is your value or belief system? These questions are, of course, implicit in our curiosity about the characters and signify our readiness to encounter the world of the other; this encounter inevitably 
forces us to engage that world and to interrogate some of our settled biases. The encounter between texts and readers becomes truly moral when a relationship is initiated in the form of identification with characters, worldviews, or events, or rejection of the same. Either way, judgment is involved; every judgment implies responsibility, which is already a moral exercise but one whose nature is yet unknown.

The relationship between literature and ethics is as old as humanity's effort to understand the universe. As Martha Nussbaum (1999:15) explains, ancient Greek dramatists have always seen literature as a form of ethical inquiry. Dramatic poetry was no more than "ways of pursuing, a single and general question: namely, how human beings should live." Aristotle (1996:10) identifies the moral importance of narratives when he defined tragedy as

an imitation of an action that is admirable, complete and possesses magnitude; in language made pleasurable, each of its species separated in different parts, performed by actors, not through narration; effecting through pity and fear the purification of such emotions.

Tragedy is thus a way of re-presenting some painful aspects of human life that are deemed important, especially for the purpose of underlining them.

Aristotle is proposing the most basic co-feeling produced in the audience by the tragic condition being performed on the stage. Stephen Halliwell (1998:175) states that pity and fear should be understood as the "capacity to sympathize with the sufferer." Thus, what is performed on the stage are those aspects of the human condition whose goal, among other things, is to bring the audience emotionally closer to the figures on the stage. He emphasizes that "Aristotle does not derive this sympathy from an undifferentiated sense of humanity: instead, he takes it to be rooted in a felt or perceived affinity between the subject and the object of the emotion." In that regard, tragic characters "have to be within the reach of an audience's compassion" (175-179). Halliwell's use of the word compassion goes beyond the limited scope of sympathy and seems to be closer to what true stories do in our lives; they help us develop empathy, as David Swanger (1993) suggests. What is important, therefore, is the fact that the piece of representation, whether performed on the stage or read in the pages of a book, unleashes a torrent of emotions in the audience.

\section{The ordinary virtues and their limits: the need for stories}

As I have sought to establish in the introductory part of this chapter, Michael Ignatieff has aptly articulated the growing skepticism associated with the notion of universal human rights. For him, human rights and the ordinary virtues are in tension, and he privileges the latter. Indeed, for him,

Human rights enjoins citizens to be morally consistent and universalistic in their perspective toward strangers in danger, but ordinary virtue 
will always pull them toward favoring citizens close to home. The meeting point between the language of rights and the ordinary virtues is actually the language of compassion, pity, and generosity.

(2017b:214)

The core of the tension between human rights and the ordinary virtues, as Ignatieff argues, lies in the fact that the human rights activist or the global ethicist is concerned only with the vulnerable universal human being while ignoring human differences such as race, class, or situation, and regarding "the distinction, for example, between a citizen and a stranger as morally irrelevant"; the person informed by ordinary virtues on the other hand, "the citizen-stranger, the us-versus-them distinction, was the first consideration, the starting point for decision making. The universal human being was rarely if ever the object of ultimate concern" (2017b:207-208).

Ignatieff is correct to highlight the basic, individualistic instinct in all ethical concerns. We care most about those we know. Yet, when he states that majority of those he and his team interviewed rather imagined their "own reflection in the mirror" (2017b:208) while justifying their behavior, he seems to see them as mere narcissists, denying them the power of imagination to put themselves in the position of peoples elsewhere and to respond to their humanity (2017b:208). He seems to paint a particularly bleak picture of the human person. There is, in any case, some truth in the suggestion that humans are largely ruled by tribal instincts. The other side of that truth is that when they get to know other people, they also get to care about them. To know is to care. Given that both the universal ethicist and the local ordinary virtue practitioner care about humans, what seems to be at stake here is the language in which that care is couched on the one hand, and on the other the degree of affinity, that is, the problem associated with knowing others. This is indeed the case, unless Ignatieff is implying that the local person is essentially xenophobic.

Perhaps a few questions that the practitioner of ordinary virtues must answer include: Do we have the obligation to save a drowning person, regardless of the gender or the color of the person's skin? What does saving or not saving him or her say about our conception of the common good or moral frameworks as humans? ${ }^{3}$ Do we have the obligation to care about civilians in war zones or strangers in our midst? Essentially, the difference between universal human rights and the ordinary virtues is this: The ordinary virtues urge us to respect somebody because we know him or her. UDHR tells us to do the same because he or she is a human being. My sympathy lies with the latter, and this does not deny my right to love my relatives more because of my obligation to them. But that leaves us with the question of how to bridge the gap between the two, the tension between universal human rights and the ordinary virtues, without delimiting their impact or making them seem to necessarily exclude each other. 
It is true that to care is necessarily to care about the people one knows. But we also live in a world that is increasingly shrinking due to globalization and mass migration. Our world is becoming a global village, despite the rise of tribal sentiments. This calls for putting the ordinary virtues "on steroids," to use Carl Pope's (2010:294) expression regarding the environment. It calls for increasing the circle of people we know, or specifically, to keep our horizon open for the yet to be known. So, the question is how to reduce the "difference and otherness" (Ignatieff 2017b:210) that dominate the world of ordinary virtues and possibly increase the awareness of the togetherness of our common humanity.

Thus far, we have established that a narrative achieves at least two things: (1) It delivers the world of others to us and makes it understandable, thus making it easier for us to relate to them (Palumbo-Liu 2012:3-9), and (2) it provokes some degree of affective identification or rejection of what has been delivered to us; it conveys values. In both cases, we encounter a new world, and this encounter has a lot in common with those we have in real life. It differs significantly, though, in terms of its composition. In real life, we meet people fairly as they are, not always in neatly packaged formats. Stories are neatly structured, and the materials that make up their composition are meticulously selected. As Wolfgang Iser (1980) argues, the act of selecting materials for a story heavily affects the manner of its reception. The storytellers select materials they believe will achieve the most dramatic effect. They plot carefully.

To explain the ethical content of Aristotle's definition of tragedy, Paul Ricoeur (1991:21) introduces the notion of emplotment. For him, "the plot serves to make one story out of the multiple incidents or, if you prefer, transforms the many incidents into one story." Even when we narrate the stories of our lives, as was the case with the South African TRC, we select only materials we believe would make the most impact and arrange them in a way that would be most coherent; we hope that our stories would make us less strange to our listeners - that is, make it easier for them to apply ordinary virtues to us. Through emplotment, the disparate incidents in a particular life are organized into a distinct meaning-making narrative. Interpretation is not confined to reading; every act of telling is an interpretation that is also an appeal to the reader. Stated simply, the story says: Can you feel what I feel? Do you understand me? It is the narrator's ardent wish not to remain anonymous or a stranger.

Stories have, indeed, been the most effective ways of teaching lessons about life and the dignity of every human. For instance, consider the parable of the Good Samaritan. When a legal scholar posed a question to Jesus about the love of God and the nature of our neighbor, Jesus did not engage in abstract legalism; he told the story of the Good Samaritan. In this story, a certain Jewish trader traveling from Jerusalem to Jericho is robbed, severely beaten, and left for dead. A priest passes by, but pays the man no attention. A Levite does the same. Only a Samaritan stops and helps the man (Luke 10:25-37). What 
is of interest in the parable is the choice of characters: a priest, a Levite, and a Samaritan. The scholar recognized that the assaulted man's true neighbor is neither the priest nor the Levite, who are Jews, but rather the Samaritan, who is not ethnically related to the assaulted man. The story forced the scholar to make a moral judgment. Essentially, then, narration is not a blind act. It is designed to achieve some effects - in this case, to drive home a moral lesson about the universal nature of love. Thus, in the Samaritan and the business man, the abstract notion of love of all humans meet the concreteness of care. In light of Aristotle's notion of tragedy, narration is a moral act, for the writer also reveals his or her biases in the act of selection. As I suggested in the introduction, a writer who writes about an issue such as toxic waste disposed in some part of Africa is already assuming that the reader will be moved to make a judgment; he or she wants us to care about the people we do not know. But the writer can never be sure of the reader's response, and that is why works of fiction are an appeal, albeit a structured and calculated one.

I am drawn to Jean-Paul Sartre's (1988:54) timeless observation that "all literary work is an appeal. To write is to make an appeal to the reader that he lead into objective existence the revelation which I have undertaken by means of language." I understand this appeal in terms of the demands of the ordinary virtues, the demand to imagine these otherwise strange persons presented to us in stories as if they were our neighbors. Taking this leap of imagination is not an easy task, but there lies the seed of the universality of human rights. What makes the difference here is whether we are relating to a person because he or she is our tribesperson or we are relating to him or her simply because he or she is a human being.

As in the parable, to become engaged in the narrated details of a human life is an ethical act, crossing the bridge of foreignness and reaching out to the other in a gesture that binds both to the same humanity. This is an act that at the least de-exoticizes the stranger. Only when a story presents important details without forcing itself on the reader does the narrator evoke a sympathetic understanding, which takes into account various aspects of the lives of individuals as parts of a comprehensive whole. Meaningful links between different and often contradictory events are formed in ways that lead to insight. It becomes obvious, therefore, that we cannot fully understand a particular incident in a person's life without knowing many other details. This is a special domain of the hermeneutic circle that states that "we must understand the whole from the individual and the individual from the whole" (Gadamer 1988:68-78). The understanding provided by a narrative in this way is rooted in our imaginative reconstruction of people's experiences. In this reconstruction, we literally become these otherwise strange "others." We live their lives. It is in this regard that Mark Johnson (1993:x) argues that moral reasoning is basically an imaginative activity because it "requires imagination to discern what is morally relevant in situations, to understand, empathetically, how others experience things, and to envision the full range of possibilities open to us in a particular case." 
Following Johnson's definition of moral reasoning, understanding others' experiences gives us the added advantage of creating a more humane, less legalistic community. To be sure, we can never fully understand the other's experience; we can only approximate it by a leap of imagination. We cannot do away with legal frameworks either. Stories help us in that regard. Following Johnson's suggestion, morality is always about our actual concrete relations to others, and these relations can be enhanced by stories. Thus, stories help us become moral agents. In the context of the world presented to us by stories, what really counts is the fact that these others are humans. Given that stories have stripped them of their strangeness, we are then more able to relate to them in ways we would want to be related to if we were in their position. From this perspective, therefore, the UDHR no longer appears as abstract as it sounds, and nor do concepts such as autonomy, dignity, and justice. To apply them to the people we know as to those we had not known, therefore, becomes a matter of stretching our imagination.

\section{We tell stories for the sake of the common good}

From the foregoing we can infer that the relationship between narrative and morality is indirect - that is, literature affects moral consciousness indirectly by initiating a thought process or identification with a world and for the sake of the common good. Donald Morrison (2013:182) differentiates between the common good and the public good. The public good, as understood by economists, "is a good that is equally available to others, and no one can be effectively excluded from use of the good." The public good is essential to the pursuit of the common good, which is moral, universal, and permanent.

The notion of the common good can be traced back to Aristotle's conception of the city-state. Every community, he argues, is established with a view of some good. And since every community is "formed for the sake of some good" it is clear that "the community that has the most control of all, and encompasses all the others, aims both at the good that has the most control of all and does so to the highest degree" (Aristotle 2017:2). It is instructive that community is central in this assertion; it can be assumed that whatever good comes from the act of establishing a community must serve those who established it and for whom it is established: all those who live in it. Good is then understood as what serves all. ${ }^{4}$ Aristotle further explains that the community comes together "for the sake of living, but it exists for the sake of living well" (2017:3).

What does it mean to live well, for Aristotle? What is the good life for which the community exists? For that, we turn to his ethics, specifically to the concept of eudaimonia - human flourishing or prosperity, which I have already referred to in the introduction. To add to my discussion in this chapter, human flourishing refers to a condition in which every free individual achieves optimal well-being, a condition in which individuals feel integrated 
and respected in their community. This cannot come about without a framework, that is, a standard of acceptable ways of relating to others. There is therefore a link between the feeling of dignity and the community. Conversely, the community exists to create a space in which individuals achieve their highest happiness or fulfillment. The "common good" is the enabling condition for individuals to achieve eudaimonia. It is important to note the emphasis laid on the individual. Happiness takes place only in the individual, but it cannot be realized through excluding others. So the community exists for all, and all are ethically obliged to ensure its survival. At this stage, regarding our discussion of narratives and human rights, we can provide a preliminary standard for judging a story: Does it help or hamper the realization of the common good? Does it increase or limit the freedom of individuals? Does it help to bring the other closer to us, familiarize him or her to us so that we can relate to him or her as we would like to be related to if we were in his or her situation?

Dorothea Frede (2013:14-15) argues that the core of Aristotle's ethics is political and that "ethics is part of politics because the life of an entire community is a higher aim than the life of an individual, has a deeper background." Perhaps one might add that in Aristotle's thinking, the life of a community is higher than that of the individual if and only if the community truly lives in tune with its calling as a space that assures individual freedom and well-being. ${ }^{5}$

\section{Ubuntu as an act of storytelling}

To narrate is to situate oneself or at least fictional characters phenomenologically in the manner of "This is me. Here I am." This is an acknowledgment of oneself as an embodied being. In stories, we articulate a particular sense of ourselves. We also get a sense of other selves and the kind of world they want to live in; we present ourselves to the other, and we do so in all our vulnerability. Stories provide the answer to the questions implicit in the act of reading, such as "Who are you?" and "Where are you from?" In a story, the narrator says: This is who I am.

In stories, we aim to achieve the ethical premise of $u b u n t u$ articulated in the now-famous phrase embodying the African traditional conception of community: "I am because you are." The dialogical relationship captured in that expression reflects that which exists between texts and readers. I have discussed ubuntu elsewhere (Eze 2017), but I think it merits more attention, especially in light of the philosophical contexts of narratives and justice in Africa. The core of this ethical attitude is captured in the expression "Ubuntu ngumuntu ngabantu," or "A person is a person through other persons." Desmond Tutu (1999:31) states that ubuntu "speaks of the very essence of being human. [It implies] ... My humanity is caught up, is inextricably bound up, in yours." We belong in a bundle of life." Ubuntu can be seen in this light as a common search for meaning. Revealingly enough, at least in the context of the critique 
of the abstract nature of human rights, Archbishop Tutu contrasts ubuntu with the Western notion of the individual. "It is not, 'I think therefore I am.' It says rather, 'I am human because I belong. I participate. I share" (31).

Stories present us with a world that draws us into the context of "I participate. I share." We participate or share in other people's lives and let ours open to be shared. As the Nigerian human rights scholar Bonny Ibhawoh (2018:32) argues:

from the standpoint of Ubuntu, there can be no human rights without community. What makes Ubuntu as an African moral principle so significant for human rights is that it helps us see individuals not as isolated entities, but as linked in a web of social relationships founded on empathy and compassion.

Ibhawo anchors the notion of human rights in the African traditional moral world and in the long history of African liberation struggles, which culminated with Nelson Mandela. The South African philosopher Thaddeus Metz (2011:537) argues that the expression "A person is a person through other persons" captures

a normative account of what we ought to most value in life. Personhood, selfhood and humanness ... are value-laden concepts. That is, one can be more or less of a person, self or human being, where the more one is, the better. One's ultimate goal in life should be to become a (complete) person, a (true) self or a (genuine) human being.

I fully agree with this interpretation of the moral agency implicit in that expression, especially in light of Metz's conclusion, that "One becomes a moral person insofar as one honours communal relationships" (2011:547). His emphasis on the development of moral personhood can also be understood within the context of the UDHR as a call to all to provide an enabling ambience in which every individual can flourish and in which people relate to one another in the spirit of brotherhood and sisterhood. In this way, moral personhood begins the moment an individual becomes aware of the degree to which he or she contributes to the affirmation of others because, according to the expression "I am because you are," it holds that this other cannot be who he or she is without oneself. This expression can also be taken to mean that our values attain meaning or justification only within our agreed framework. We are therefore bound to the common good. Within the context of ubuntu, therefore, the body is always embedded in the community. ${ }^{6}$ The expression "I am because you are" places the condition of the existence of my body in that of the other. The you refers to both the singular and plural forms of the second person. Human flourishing implies the flourishing of the individual in the company of others. Narratives take all the above conditions as given. 
Every story depends on a reader to make sense of it. Somehow, the story begs the reader to bring it into full existence. In the same way, the storyteller appeals to the listening world. Even in the act of telling, the reader is present, if only by implication. In reading, the storyteller is also present. At any rate, there is a meeting of two worlds, and the nature of this meeting is uncertain and fragile. One thing is certain, though: Dialogue exists between these two, however tenuous, and there is a meeting and melding of horizons. Within the hermeneutic parameters of "I am because you are," one is impelled to grant the other recognition by the grace of their shared human condition. In this regard, a moral framework or the common good is the space in which we acknowledge the fundamental importance of the other presented to us in a story and the necessity of our accommodating the other.

To narrate oneself is to consider oneself seriously enough to be heard as much as it is to consider the other seriously enough to listen to oneself. Narrative speaks to that common moral ecosystem shared by the narrator and the audience. We need morality to live, just as we need stories. We have to make sense of our lives. Ubuntu is storytelling insofar as the narrator cannot function and the narrated world cannot make sense without the listener/ reader. It is a process of making meaning together.

\section{Justice as an element of the common good}

My concern in the foregoing sections is to establish the framework within which the moral assumptions of human rights can best be approached and to argue that narrative can help us achieve it. In this section, I provide a more detailed discussion of human rights - an instantiation of justice - especially in relation to Africa. I discuss universal human rights as an important aspect of the moral framework of any decent society. My proposition is simple: Whoever believes in decent societies and that ordinary virtues are nonnegotiable must believe in human rights. Human rights are merely ordinary virtues amplified to the community level.

Africa has seen a growing interest in human rights and more scholarly discussions of the topic. Most of them explore either its cultural or legal aspects. Sylvia Tamale's (2008) "The Right to Culture and the Culture of Rights" and Abdullahi Ahmed An-Na'im's (1990) Human Rights in Africa: Cross-cultural Perspectives examine the cultural aspects of human rights in Africa. As I have already pointed out, Bonny Ibhawoh provides a rich historical analysis of human rights thought and movements in African postcolonial history. Rachel Murray's (2004) Human Rights in Africa: From the $O A U$ to the African Union examines how the Organization of African Unity has dealt with human rights since its inception.

I take my understanding of human rights as those enshrined in the Universal Declaration of Human Rights (UDHR) in 1948 by the United Nations. More fundamentally, they are those rights that humans have by the mere fact of being human, as Jack Donnelly (2003) has exhaustively explained. 
It is comparable to the rights one enjoys in the family into which one is born. A member of a family automatically carries the family name and lives in the house that belongs to the family by merely being born into it. According to James Nickel (2017),

Human rights are norms that help to protect all people everywhere from severe political, legal, and social abuses. Examples of human rights are the right to freedom of religion, the right to a fair trial when charged with a crime, the right not to be tortured, and the right to engage in political activity. These rights exist in morality and in law at the national and international levels.

Important in this definition is the notion that the norms and the rights they protect exist in both morality and law. Whereas some laws could be arbitrary, morality, as is implied in the UDHR, is as timeless as humanity itself. My interest lies in this latter aspect of human rights, and my discussion of human rights here is based on Article 1 of the UDHR: "All human beings are born free and equal in dignity and rights. They are endowed with reason and conscience and should act towards one another in a spirit of brotherhood" (United Nations). The Declaration is undoubtedly a legal document. For the purposes of my discussion, especially in light of the conception of the common good as an ethical property, I restrict myself to the moral aspect of human rights. To that effect, the concepts of dignity, conscience, and spirit of brotherhood (and sisterhood) take a prominent place in my discussions of the narratives or incidents that add to our appreciation of human rights.

The preamble of the Declaration addresses human dignity in the very first lines of the document: "recognition of the inherent dignity and of the equal and inalienable rights of all members of the human family is the foundation of freedom, justice and peace in the world" (United Nations). The Council of Europe's manual for educating young people about human rights brings this idea home in its claim that "Human rights are moral entitlements that every individual in the world possesses simply by virtue of the fact that he or she is a human being" (Council of Europe). It is instructive that human rights is described as a "moral entitlement" and that we understand it as a claim that an individual can make upon others. Perhaps the reason it is a claim has to do with what we have already identified as the common good. As with being born into a family, occupying the same moral framework as others - a quality that differentiates humans from brutes - is the justification for demanding honor and respect. So, respect is not a privilege, but rather a thing every individual must claim in every decent society.

The Council of Europe explains further that this moral claim is what individuals make on their government and on their fellow humans; they tell their governments "You cannot do that, because it is a violation of my moral sphere and my personal dignity. No one-no individual, no governmentcan ever take away our human rights" (Council of Europe). Their linking of 
moral sphere and personal dignity is related to another important concept in Article 1 of the Declaration: conscience. A moral sphere refers to the quality or condition in which a person is deemed capable of making decisions about his or her life. Being a member of the human race already qualifies one as possessing a moral sphere, regardless of the state the person is - that is, whether the person is a child, mentally challenged, in a coma, or an adult in full possession of his or her faculties. It means acting as a moral agent, which all humans are by the grace of being human.

As sentient beings, only individuals know what they feel and are thus the only persons who can know what is good or bad for them; that is, they are the only ones to justify those feelings. If every individual has the right to decide what is good for him or her, it implies that his or her moral/individual space is inviolable. No one, no state, and no agency can take over the individual agency, except when the individual is incapacitated or is deemed dangerous to the state, in which case the law takes care of that person. The profound implication here is that the abuse of human rights begins on the microcosmic and most basic ethical level when people violate other people's moral spheres and make decisions that adversely affect other people's lives without consulting them. The spirit of brotherhood is the fundamental imperative that directs all humans to act in a way that upholds the framework outside of which one's life has no meaning. Without this moral force, the UDHR's claim to universality would be arbitrary. The spirit of brotherhood is the backdrop against which ordinary virtues make sense.

It is customary to think of human rights abuses only when heinous crimes are committed against a person or a group of people. I think it is more fruitful to emphasize the microcosmic level of human rights abuse or its appreciation, the level that ultimately leads to the large-scale abuses that often attract the public's attention. I do this in the belief that all the wellknown cases of abuse of human rights, all forms of atrocities in history, did not start with spontaneous, explosive outbreak of violence. They all started with some form of gradual disregard for the other, and this disregard is nurtured in narratives until it is baked into beliefs and ideology and become a widely accepted form of prejudice.

Not all cultures or parts of the world accept the logic that human rights holds universally. This is due to some problems inherent in its conception and execution. As Lora Wildenthal (2012) has observed, human rights language is abstract and ahistorical because of the original intention of the advocates of human rights to capture the universality of its underlining ideas. For her, the abstract universality of human rights discourse is a problem for historians, who seek to understand language in a particular time and place.

The abstract nature of the language of human rights is a problem not only for historians; it is much more so for cultures outside the logocentric Western world - that is, one that is centered on the primacy of reason over all human faculties. Indeed, the second sentence of the Declaration underlines that aspect of Western thought; it refers to humans as "endowed with reason 
and conscience." It implicitly downplays any conception of the human that would highlight feeling, since feeling was thought to belong to lower animals. Elizabeth S. Anker traces the problems associated with this aspect of human rights' origins in the European liberal tradition, which privileged logos over the body. She argues that even though the notions of human dignity on which the UDHR is based are useful, they are ultimately fictions because of the "contradictory status of the body within" that liberal tradition, which

posits a dangerously purified subject, one purged of the body's assumedly anarchic appetencies: its needs and desires, its vulnerabilities and decay. And when the body cannot be thus ignored, the liberal tradition generally treats it as an entity that must be repressed, quarantined, or otherwise mastered by reason.

(Anker 2012:4)

The notion of human rights resting on reason was therefore a product of an abstract conception of the human that is traceable to Plato's ideal world via Christian theology via Descartes's cogito, and this world notoriously considers the body to be inferior to the mind.

Highlighting some of the issues associated with the Western origins of human rights, Professor Lynn Hunt, one of the eminent historians of human rights, suggests that one of the origins of human rights as entrenched in the 1948 Declaration can be traced back to the American Declaration of Independence. Hunt points out the obvious contradiction in the idea of human rights and its implementation in practice. Those who claimed that rights were universal were not inclusive in their treatment of their fellow humans, as women and black people were not part of the equation in Europe and America at the time. Thomas Jefferson, one of the pioneers of this universal idea, was at the same time a slaveholder and a strong proponent of the notion that black people were not equal to whites.

Opponents of the UDHR seize upon some of these ideas to claim that the notion of human rights is a European cultural construct and cannot be applied to all cultures (Howard-Hassmann 1995). Some contend that the ideas behind the documents cannot be universal because they are deeply rooted in a Western liberal conception of the world, especially its prioritizing of the individual over the community (Ramcharan 1998; Tharoor 1999/2000). Some people even propose a postcolonial argument to the effect that human rights are parts of a Western ploy to impose itself on the rest of the world and therefore cannot be universal (O'Sullivan 2000). Some of these critics rely on cultural relativism to counter human rights' claim to universalism (Donnelly 1984:400-419).

Nigerian human rights lawyer Chidi Anselm Odinkalu (1999) has observed that Africans "do not describe their problems in human rights terms. Many communities and groups involved in social justice movements and initiatives in Africa are reluctant to make the Universal Declaration, or 
language inspired by it, their mascot or medium." As most African scholars of human rights argue, Africa is not averse to the spirit of the UDHR. They, however, point to African conceptions of human rights are codified in the African Commission on Human and Peoples' Rights, also known as the Banjul Charter (African Commission). There are, however, disagreements as to the specificities derived from its genealogy.

It seems to me to amount to a purely academic exercise to debate the proper designation of the struggles for African people to attain dignity. It is not the goal of this book to judge the adequacy of terms. It is, however, fair to state that the Banjul Charter highlights some of the general criticisms leveled against UDHR but does not disagree with its moral assumptions. Both declarations have one thing in common: the quest for justice, pursuit of human dignity, and the common good.

\section{Making human rights palpable in Africa}

The abovementioned weaknesses of the conception of human rights notwithstanding, an important strain in the evolution of human rights in the West stands out, and when examined closely, can enhance the appreciation of human rights in general. It is the role of fellow feeling. As Lynn Hunt (2007:29) argues, human rights becomes self-evident in the cultural practices that recognize that "others feel and think as we do, that our inner feelings are alike in some fundamental fashion." Hunt argues further that "autonomy and empathy did not materialize out of thin air in the eighteenth century; they had deep roots" in the maturation of European culture over time. Part of that maturation is what she calls "imagined empathy," by which she means "the sense that empathy requires a leap of faith, of imagining that someone else is like you" (32).

Against the backdrop of the abovementioned difficulties associated with the universal notion of human rights, I return to a central aspect of this book: How do we make the universality and abstractness of the notion of justice or human rights as formulated in the UDHR palpable to Africa? How can I get an African, who sees a person living with albinism as exotic and therefore deserving of no empathy, to admit that the albino has inherent dignity? How do I convince a traditional African man that his wife and his daughters deserve the same dignity and right as he and his sons do? Can I convince most Africans that persons with alternative sexualities have the basic right to be left alone to live their lives? How do we make respect for every individual take a prominent place in our moral framework? In the introductory chapter, I stated that narratability is a litmus test of the universal nature of concrete rights. The test is this: Can it be explained in a story format? Stories widen our moral horizons by making space for others in our lives.

We must keep telling stories; we must tell the story of how people with albinism feel when being bullied or even hunted down for their body parts. We must hear the words of a lonely elderly woman accused of witchcraft in an 
African village. Whatever can get people to imagine the pain of these people is welcome. Stories cut across the chatter and abstractions of arguments; they present us humans as we are in our embodiedness and vulnerabilities and can help us imagine that these others are like us. Stories are vectors of values, and telling stories about other people imbues all concerned with dignity.

The question of whether an issue can be put in story formats assumes a few things, one of which is that telling a story necessarily makes humans feel the humanity of others and thus respect their human rights. This is not always the case. It is worth noting that human rights are also hampered by stories, the negative stories we tell about others. The Nazis told stories about Jews, characterizing them as vermin. Indeed, stories have been misused in the history of humanity even before Hitler. Stories have always been vectors of truth and untruth. However, some details make some fundamental differences between stories that make the abstract notion of human rights concrete and others that work against human rights. In other words, there are differences between stories that arise from the human condition and those designed to further an agenda. The former makes sure that humans are presented as living, breathing entities possessing the many dimensions of being human; the latter rests on generalizations and one-dimensional portraits of otherwise complex characters. Humans are neither angels nor demons; stories arising from this awareness do no more than further an understanding of the human. They do not promote specific agendas. To that effect, I follow South African scholar Njabulo Ndebele's conception of an ideal African literature, one capable of initiating appreciation of the other and convivial living.

In "The Rediscovery of the Ordinary," Ndebele (1986:144) critiques the apartheid-era South African writers who adopted protest literature as a way to confront apartheid. His concern was not with the goal of the writers, which was the liberation of the oppressed black population; rather, he was much more interested in their method as literary artists. He argues that their approach has two main flaws: (1) It does not enhance the understanding of literature as a work of art, capable of highlighting the human condition, and (2) it does not contribute to the creation of moral frameworks. Protest writing was bound to fail because not only did it fail to change the system it was challenging, it also replicated in a less obvious manner the system's spectacles, which notoriously objectivized humans. Ndebele calls the writers' approach "spectacle" because they produced "spectacular representations of reality." Like the spectacular, their writing preferred "the larger issues of society in our minds, obliterating the details.... It is the literature of the powerless identifying the key factor responsible for their powerlessness" (149-150).

We note Ndebele's observation about the powerless identifying the key factor responsible for their powerlessness. Important here is the object of attention - namely, the source of their oppression — not their condition as 
humans whose state of life includes being oppressed. Part of Ndebele's contention is that narratives that mimic an oppressive machinery ultimately fail to create a moral framework for a better society.

A spectacle is whatever captures the immediate short-term imagination of the spectator, such as wrestling matches or the gladiator fights in amphitheaters in ancient Rome. It is what is designed to please an immediate emotional need, a jolt of adrenalin; it does nothing for the spiritual side of the human, nothing that provokes introspection or leads to thoughts about the human condition. Ndebele states that some of the major characteristics of the spectacular are that "it provokes identification through recognition and feeling rather than through observation and analytical thought; it calls for emotion rather than conviction; it establishes a vast sense of presence without offering intimate knowledge" (49). Ndebele does not dismiss feeling or identification as a product of reading; what he is against is the condition in which a story is produced, and precisely for defined goals. He falls short of calling those stories propaganda. Any story's first goal should be to explore the human condition and present it to the other as an appeal. Anything that offers $a$ vast sense of presence or knowledge without offering intimate knowledge is nothing short of ideology or propaganda. It is abstract and ultimately ignores the moral sphere or dignity of the individual. It fails our test of narratability.

By narratability, therefore, I mean the ability of the storyteller/writer to use the ordinary details of a life to divest that life of all ideological abstractions and to present it to people, enjoining them with the strength of its narrative gestures to consider that life as if it were theirs. This hypothetical condition is truthful in a work of fiction to the degree that it invites the use of the imagination. The leap of empathy is precisely what narratability seeks to achieve; it makes the life of the other relatable. In this way, narratability makes concrete the universal and universalizes the concrete. In sum, therefore, the conditions of narratability are (1) the story must arise from the human condition, (2) it must be relatable, and (3) it must be based on the practice of the ordinary. In light of the notion of narratability, I propose that all human rights discourses in Africa begin with the body-the body that feels pain and pleasure, the body that must not be violated, and the body that must be respected as if it were one's own.

One of the discourse modalities for engaging human rights at the grassroots level is to emphasize the condition of those who suffer pain due to no fault of their own. What we owe others reflects what they owe us, should we find ourselves in their shoes. If the language of human rights is abstract and if the practice of human rights is being imposed from above, only stories can make their noble ideals and aspirations palpable to people. Narratives therefore make the abstract language of human rights concrete and provide us with functional vocabularies to engage reality more fruitfully. The goal of human rights advocacy in this regard is to make the issue primarily about people's individual responses to fellow human beings. ${ }^{7}$ It is to place the responsibility 
of caring for our common moral framework squarely in the laps of individuals. It is not the duty of the government to ensure that we love our neighbors and respect one another as humans; it is the duty of the individual in the community. This duty is just an integral part of our being human.

I stated above that people are accustomed to read human rights violations only as egregious forms of violence such as torture, disappearance, and genocide; human rights violations can unfold in subtler, insidious ways over time. They also begin the very moment we consider another person disposable and relate to them accordingly, either verbally or in our actions. These attitudes invariably begin with the stories we tell about them. Some of the incidents of human rights abuses in the selected texts and films are rather obvious, while many others are less so. When I analyze texts in relation to human rights, I shall be looking for situations in which humans are considered inferior or undeserving of dignity, especially in the myths or seen as means to ends rather than as ends in themselves. I shall be asking, explicitly or implicitly, whether an individual's or group's dignity or moral sphere has been respected or violated, and whether people relate to one another "in the spirit of brotherhood." Above all, my interest in the explication of the texts lies in their effectiveness in making palpable the otherwise abstract notion of justice. I shall be asking the questions implicit in the lives of the characters: Aren't we, too, humans?

\section{Notes}

1 It is anyhow becoming increasingly difficult to hold to such critiques even in the West, especially in the aftermath of poststructuralism and in times like ours in which people look for moral clarity in sociopolitical life.

2 I grant that many people might disagree with the man. For now, though, we must accept his version of justice which seems to suggest his satisfaction at having been restored to the community by the mere act of being listened to. To be sure, the past cannot be undone, and neither can punishing those who inflicted harm on him.

3 To be sure, the human rights of a drowning person or a person experiencing unmerited pain is not rooted in the perception of the person as a victim; the person has the right to be relieved of the unbearable condition and helped to reach a different condition in which he or she can exercise his or her autonomy. The goal therefore is creating a condition in which people can flourish by exercising their moral agency.

4 The question, though, is who chooses to be part of that community? We know that the city-state Aristotle was addressing did not consider slaves worthy of the virtues accorded to others. Nor did the American Constitution consider women and slaves as equal members of the union.

5 Of course, we know that the notion of community could become tyrannical. It could become so when it is used to suppress individual freedom and well-being.

6 This, of course, does not do away with rationality or the need to aim for universality. It is also important to note that the body is not defined by specific characteristics such as white/black/brown, but rather as a human body that feels pain and pleasure.

7 The need for laws that bind people to the agreed frameworks will surely arise from their understanding. 


\section{References}

Abdullahi, An-Na'im and Francis M. Deng, eds. 1990. Human Rights in Africa: Cross-Cultural Perspectives. Washington, DC: The Brookings Institute.

African Commission on Human and Peoples' Rights. No date. "African Charter on Human and Peoples' Rights." http://www.achpr.org/instruments/achpr/\#a29 (Accessed December 12, 2019).

Anker, Elizabeth S. 2012. Fictions of Dignity: Embodying Human Rights in World Literature. Ithaca, NY: Cornell University Press.

Aristotle. 1996. Poetics. Translated by Malcolm Heath. London: Penguin Books.

Aristotle. 2017. Politics. Translated by C. D. C. Reeve. Indianapolis, IN: Hackett Publishing.

Council of Europe. No date. "Compass: Manual for Human Rights Education with Young People." https://www.coe.int/en/web/compass/questions-and-answersabout-human-rights.

Coundouriotis, Eleni. 2006. "The Dignity of the 'Unfittest': Victims' Stories in South Africa." Human Rights Quarterly 28 (4): 842-867.

Dawes, James. 2009. "Human Rights in Literary Studies.” Human Rights Quarterly 31(2): 394-409.

Dawes, James. 2018. The Novel of Human Rights. Cambridge, MA: Harvard University Press.

Didion, Joan. 2006. We Tell Ourselves Stories in Oder to Live: Collected Nonfiction. New York: Alfred Knopf.

Donnelly, Jack. 1984. "Cultural Relativism and Universal Human Rights." Human Rights Quarterly 6 (4): 400-419.

Donnelly, Jack. 2003. Universal Human Rights in Theory and Practice (2nd Edition). Ithaca, NY: Cornel University Press.

Eze, Chielozona. 2017. "Empathetic Cosmopolitanism: South Africa and the Quest for Global Citizenship.” Strategic Review for Southern Africa 39 (1): 236-255.

Fisher, Walter R. 1984. "Narration as a Human Communication Paradigm: The Case of Public Moral Argument." Communication Monographs 51 (1): 1-22.

Frank, Arthur W. 2010. Letting Stories Breathe. Chicago, IL: The University of Chicago Press.

Frede, Dorothea. 2013. "The Political Character of Aristotle's Ethics," pp. 14-37 in The Cambridge Companion to Aristotle's Politics, edited by Marguerite Deslauriers and Pierre Destrée. New York: Cambridge University Press.

Gadamer, Hans Georg. 1988. "On the Circle of Understanding," pp. 68-78 in Hermeneutics versus Science? Three German Views, edited by J. M. Connolly and T. Keutner. Notre Dame, IN: University of Notre Dame Press.

Halliwell, Stephen. 1998. Aristotle's Poetics. Chicago, IL: University of Chicago Press.

Horton, Scott. 2007. "Roosevelt on Human Rights in Small Places.” Harper's Magazine. https://harpers.org/blog/2007/12/roosevelt-on-human-rights-in-the-smallplaces/ (Accessed September 12, 2020).

Howard-Hassmann, Rhoda E. 1995. Human Rights and the Search for Community. Boulder, CO: Westview Press.

Hunt, Lynn. 2007. Inventing Human Rights: A History. New York: W. W. Norton \& Company.

Ibhawoh, Bonny. 2018. Human Rights in Africa: New Approaches to African History. New York: Cambridge University Press. 
Ignatieff, Michael. 2017a. "Human Rights, Global Ethics, and the Ordinary Virtues.” Ethics \& International Affairs 31 (1): 3-16.

Ignatieff, Michael. 2017b. The Ordinary Virtues: Moral Order in a Divided World. Cambridge, MA: Harvard University Press.

Iser, Wolfgang. 1980. The Act of Reading: A Theory of Aesthetic Response. Baltimore, MD: Johns Hopkins University Press.

Johnson, Mark. 1993. Moral Imagination. Chicago, IL: The University of Chicago Press.

Metz, Thaddeus. 2011. "Ubuntu as a Moral Theory and Human Rights in South Africa." African Human Rights Law Journal 11 (2): 532-599.

Morrison, Donald. 2013. "The Common Good," pp. 176-198 in The Cambridge Companion to Aristotle's Politics, edited by Marguerite Deslauriers and Pierre Destrée. New York: Cambridge University Press.

Murray, Rachel. 2004. Human Rights in Africa: From the OAU to the African Union. Cambridge: Cambridge University Press.

Ndebele, Njabulo S. 1986. "The Rediscovery of the Ordinary: Some New Writings in South Africa." Journal of Southern African Studies 12 (2): 143-157.

Nickel, James. 2017. "Human Rights," The Stanford Encyclopedia of Philosophy, edited by Edward N. Zalta, https://plato.stanford.edu/archives/spr2017/entries/ rights-human/ (Accessed March 12, 2018).

Nussbaum, Martha C. 1999. Love's Knowledge: Essays on Philosophy and Literature. New York: Oxford University Press.

Odinkalu, Chidi Anselm. 1999. "Why More Africans Don't Use Human Rights Language." Human Rights Dialogue, Series 2, Number 1.

Palumbo-Liu, David. 2012. The Deliverance of Others: Reading Literature in a Global Age. Durham, NC: Duke University Press.

Pope, Carl. 2010. "Ethics as If Tomorrow Mattered," pp. 3-9 in Moral Ground: Ethical Action for a Planet in Peril, edited by Kathleen Dean Moore and Michael P. Nelson. San Antonio, TX: Trinity University Press.

Ramcharan, B. G. 1998. "How Universal Are Human Rights?” http://library.fes.de/ pdf-files/ipg/ipg-1998-4/debate.pdf (Accessed February 24, 2018).

Ricoeur, Paul. 1991. "Life in Quest of Narrative," pp. 20-33 in On Paul Ricoeur: Narrative and Interpretation, edited by David Wood. London: Routledge.

Sartre, Jean-Paul. 1988. What is Literature? And Other Essays. Cambridge, MA: Harvard University Press.

Schaffer, Kay and Sidone Smith. 2004. Human Rights and Narrated Lives: The Ethics of Recognition. New York: Palgrave Macmillan.

Swanger, David. 1993. "The Arts, Empathy, and Aristotle." The Journal of Aesthetic Education, 27 (1): 41-49.

Tamale, Sylvia. 2008. "The Right to Culture and the Culture of Rights: A Critical Perspective on Women's Sexual Rights in Africa.” Feminist Legal Studies 16 (1): 47-69.

Tharoor, Shashi. 1999/2000. “Are Human Rights Universal?” World Policy Journal - World Policy Institute. XVI (4). http://www.worldpolicy.org/tharoor. html (Accessed February 24, 2018).

Tutu, Desmond. 1999. No Future without Forgiveness. New York: Image Doubleday. United Nations. No Date. "Universal Declaration of Human Rights." https://www. un.org/en/universal-declaration-human-rights/.

Wildenthal, Lora. 2012. The Language of Human Rights in West Germany. Philadelphia: University of Pennsylvania Press. 


\section{Ecological violence and the quest for justice}

The United Nations acknowledges the inexorable role that the care for the environment plays in human flourishing. It situates the environment as a necessary condition for human rights and thus imbues the struggle for the environment with a moral and existential character (UN Environment Programme). It is fair to say that, because all lives take place in a given space at a given time, that is, to be alive is to do so in a given environment, life and environment are the two sides of the same coin of the human condition. $\mathrm{He}$ or she who threatens my environment threatens my moral and existential space; he or she threatens me.

The main cause of the environmental degradation is the exploitation of the land occupied by indigenous people, largely in developing nations such as in Africa and Latin America, and in parts of the developed nations occupied by minorities such as in the United States. The relationship between humans and the environment is therefore not a thing of transient value; it is an issue of life and death consequence and, therefore, of urgent moral concern. Barbara Johnston (2016) rightly ties environmentalism to social justice.

The 1972 United Nations Conference on the Human Environment, or Stockholm Declaration, acknowledged that "the protection and improvement of the human environment is a major issue which affects the well-being of peoples and economic development throughout the world" (Stockholm 1972). The conference sharpened the moral urgency of the relationship between humans and the environment in the first principle of their resolution, which states that humans have the fundamental right to conditions that allow for a quality life. This implies living "in an environment of a quality that permits a life of dignity and well-being, [and humans bear] a solemn responsibility to protect and improve the environment for present and future generations" (Stockholm 1972). It is therefore the right to live, to live a decent life.

The Roman Catholic Church is unquestionably one of the most important international bodies that boast of the same moral authority the United Nations enjoys, if not more. In his encyclical, Laudato Si: On Care for Our Common Home, Pope Francis calls on all, especially his immediate audience, Catholics around the world, to evince a measure of responsibility in conserving the earth (Pope Francis 2015; Iheka 2017). To some degree, this is 
a remarkable turn in the teachings of the Catholic Church, especially given that the Church is one of the most conservative institutions where, as many feminists would claim, patriarchy is preserved in its primordial form. From the African perspective, the Catholic Church is still a colonial institution, one that actually sanctified the European conquest of the rest of the world. For example, the papal bull of 1452, Dum Diversas, authorized the kings of Spain and Portugal to invade and subjugate Saracens, pagans, and enemies of Christ and to "reduce their persons into perpetual slavery" (Hayes 2003). This is why the current pope's anti-colonialist, anti-capitalist sentiments are positively surprising and very welcome. I am personally heartened by the fact that the pope casts environmental issues in moral idioms. He states that climate change is caused largely by human activities, such as deforestation and industrial pollution, and directly affects animals and humans, especially the poor. Pollution and changes in climate affect "the livelihood of the poor, who are then forced to leave their homes, with great uncertainty for their future and that of their children" (Pope Francis 2015:20-21).

The pope seems to be echoing literary scholar and Princeton Professor Rob Nixon's notion of slow violence, especially the displacement of the poor whose land has been poisoned by the exploiting institutions of the West. The pope states,

as part of the universe, called into being by one Father, all of us are linked by unseen bonds and together form a kind of universal family, a sublime communion which fills us with a sacred, affectionate and humble respect.

The pope's appeal, understandably framed in religious language, goes straight to the heart of the moral framework that we all, as humans, must be conscious of and maintain. Preserving others from harm and taking our environment and our common home seriously is a way of taking ourselves seriously. The pope's position as the spiritual and moral leader of at least 1.2 billion people lends him immense power in matters of the environment. He therefore becomes, ipso facto, a leader in this moral issue.

In their introduction to a collection of essays on climate change and the moral challenges facing humans, Kathleen Dean Moore and Michael P. Nelson state that there is enormous scientific information about the dangers of climate change brought about by humans, and humans know that we are approaching a tipping point where climate change will cause irreversible changes in the conditions under which we all live. In their judgment, therefore, "What is missing is the moral imperative, the conviction that assuring our own comfort at terrible cost to the future is not worthy of us as moral beings" (Moore and Nelson 2010:xvi). I share their premise about environmentalism, which is that humans "have a moral obligation to avert harms to the future, so as to leave a world as rich in life and possibility as the world we inherited" (xviii). I read their concern through the prism of justice. 
Carl Pope, the executive director of the Sierra Club, is also of the opinion that the concern for the environment is now a moral imperative. He argues that whoever takes the religious and ethical injunctions seriously must also apply them to the environment. Even though the great ethical injunctions were conceived and applied locally, now that we have a truly global challenge in climate change, their values must be put to the test to determine their true universal import. It helps in this regard to pose some questions: How does environmentalism help us to fully live the moral principles of our religions and cultures, which are essentially local and form the basis of our societies' or groups' moral frameworks? Should we care if our local habits and lifestyles have consequences for lives thousands of miles and many decades removed from us? For Carl Pope (2010:294), "'[g]lobal warming means we must put our ethics on steroids - and that makes them much more challenging, threatening, and, yes, subversive and newly controversial." In other words, the nature of the global challenges of environmentalism should make us aware of the global consequences of our local ethics. We thus become aware of the consequences of our lifestyles on others, far and wide. For example, the neighbor in the injunction to "love thy neighbor" becomes any human being anywhere who is threatened by the consequences of environmental pollution. This is because we all live in the same village in matters of global climate change; this realization is the consequence of local ethical injunction writ large.

This chapter works from the premise that ecological violence is a manifestation of injustice and constitutes an abuse of human rights and human dignity. It conceives the environment as an integral part of the common good. To achieve this, I develop my argument thus: (a) I discuss the Nobel Peace Prize winner Wangari Maathai's sociocultural and political philosophy of the environment, specifically the interconnection between moral responsibility for the environment and political consciousness; (b) I analyze the neocolonial/neoliberal mindset that governs the industrialized nations' relations with developing nations regarding the environment; and (c) I discuss the writers' response to ecological violence in the oil-producing Niger Delta, Nigeria, as a quest for justice.

\section{Wangari Maathai and the cultural philosophy of the environment}

Wangari Maathai, the Nobel Prize-winning environmental activist and founder of the Greenbelt Movement, believes that the question of ecological violence is that of justice. ${ }^{1}$ In her Nobel Peace Prize address (Maathai 2005:200), she states:

In the course of history, there comes a time when humanity is called to shift to a new level of consciousness, to reach a higher moral ground. A time when we have to shed our fear and give hope to each other. This time is now ... there can be no development without sustainable management of the environment in a democratic and peaceful space. 
Maathai speaks specifically of the moral responsibility of the present generation to leave a clean environment behind for the benefit of the coming generations. She speaks of streams that have dried up and that the challenge of the present generation, therefore, "is to restore the home of the tadpoles and give back to our children a world of beauty and wonder" (201). It is the question of the present generation treating the environment in such a way that the next generation would be left with a place to flourish. Doing the opposite would be unfair, an unjust act.

I consider it important that Maathai frames her injunction about people's relationship to the environment in the positive, that is, in terms of what ought to be done rather than what others have done wrong. She underscores the individual's personal responsibility to the next generation, as if that generation were already here and now. In so doing, she treats the environment as an extension of the other, implying that anything we do to the environment is done directly to this other. She then brings the care for the environment closer to the notion of human rights and precisely because it is an issue of dignified life. In many instances, it is even a life and death issue. In her memoir, Unbowed (2007), she lays out the contexts and support for her world-famous movement, the Greenbelt Movement; it has attracted considerable scholarly attention (de Beer 2015). For this chapter, though, I focus on her book of essays, The Challenge for Africa, and more specifically on Chapter 8, "Culture: The Missing Link?"

I situate Maathai's moral capital and importance in African cosmology in her agentic conception of culture. In her book of essays, The Challenge for Africa, she makes a strong case for the importance of cultural renaissance for Africa's realignment with its environment. It is important to state from the outset that the phrase "cultural renaissance" has been abused in African discourse. It has been variously appropriated by politicians and ideologues to pursue their conservative political agenda. As Maathai (2009:164), observes, "In many communities in Africa and other regions, women are discriminated against, exploited, and controlled through prevailing cultures, which demand that they act a certain way." Such conception of culture is to be dismissed immediately. The rediscovery of Africa's cultural values is far from this. Indeed, in Maathai's uses, culture is a liberating force that empowers individuals to care about themselves, others, and the environment. The virtue of care forms the basis for my meditation on Maathai as an icon of moral responsibility toward the environment and as a promoter of enabling environment for justice and human rights. In The Challenge for Africa, Maathai states:

Culture gives a people self-identity and character. It allows them to be in harmony with their physical and spiritual environment, to form the basis for their sense of self-fulfillment and personal peace. It enhances their ability to guide themselves, make their own decisions, and protect their interests ... without culture, a community loses self-awareness and 
guidance, and grows weak and vulnerable. It disintegrates from within as it suffers a lack of identity, dignity, self-respect, and a sense of destiny.

I interpret the operative words and phrases here, "harmony with the environment" and "character," in the tradition of virtue ethics as traits necessary for a moral attitude toward the community. I reframe the tenor of her argument to imply that regaining pride in one's culture forms the basis of the protection of one's environment. Ideally, one protects what one appreciates. Culture, which gives us the means to relate to our world, therefore, becomes a legitimating force for the imperative to protect and preservevirtues that are essential for a proper conception of human rights.

Character is very important in virtue ethics and in our understanding of ordinary virtues. In Maathai's understanding, character is a constant attitude of caring engendered by culture; it allows the individual to be in harmony with the environment. For her then, culture means being grounded, which in turn means establishing an affinity with the world that one inhabits. To be sure, her notion of culture differs from the nineteenth-century conception influenced by Gottfried Herder, one which saw a people's culture as essentially defining that people as autochthonous in their space. The secret of Maathai's notion of culture lies in the Latin root word cultura, meaning "to cultivate." Above all, we cultivate character and our relationship to the other, which the environment most symbolizes.

Another operative word in Maathai's notion of culture is "self-respect"; it is the basis for integrity and moral consciousness. It is, as Harry Frankfurt (2006) explained, taking oneself seriously, which is tantamount to taking others seriously, and taking others seriously inevitably leads to taking the environment seriously. The environment is the visible common framework, strictly speaking, the first thing we have in common with others. We thus return to the argument, which is that concern for our environment leads to concern for our fellow humans and finally to the well-being of all.

Maathai grew up in a cashless economy, which prized the exchange of livestock as payment for services. She argues that the cash economy is the basis of ruthless profiteering. Even at that, people never reach any level of satisfaction because the love of having increases by having. Unlike in the pre-industrial African culture in which Maathai grew up, which did not depend on having - even though the culture was not against it — value was not placed on things but on the relationship between people. Her search for that original African culture led her to consider what she has in common not only with other Africans alive today but also with the yet-to-be born, the future generation. In this search and the discovery, Maathai suggests that the present cannot be understood in isolation of the past and especially the future generation. To live is to do so in relation to others. We are all linked up by a common destiny whose survival depends on the degree of dignity we accord ourselves; we are all connected and must therefore always 
be guided by a thinking that takes the presence of others as a given, if not as the starting point of our activities. This attitude which is fundamental to our understanding of human rights is, I think, borne of a thinking rooted in the ordinary virtues, of ubuntu, I am because you are.

Informed by the relationship between culture and care, Maathai (2009:164165) "began to listen to rural women speak of their difficulties in obtaining firewood to cook nutritious food and providing clean drinking water and fodder for their animals." Their interaction gave birth to the Green Belt Movement. The contact with these local women showed her "the linkages between poverty and environmental degradation and the loss of culture" (165), and she understood that the recognition of culture was something political and social and, ultimately, environmental. We understand politics, in both partisan uses and in the form expounded by Hannah Arendt, as the exercise of speech in the polis. If politics is the act of speech, which presupposes freedom and the awareness of right, then reclaiming ownership of one's culture, in Maathai's thinking, does no more than give the individual the courage to claim his or her voice, to speak and to assert his or her right. The absence of that courage has consequences for both humanity and the environment. For example,

[w]hen communities were told that their culture was demonic and primitive, they lost their sense of collective power and responsibility and succumbed, not to the god of love and compassion they knew, but to the gods of commercialism, materialism, and individualism.

Maathai was shocked to see the link between being culturally uprooted and the destruction of the environment; people who were uprooted culturally began to uproot trees. The next natural step after uprooting trees would be to uproot humans. This destructive attitude comes about because the person's sense of care has been destroyed. Thus, the destruction of the environment brought about by being culturally uprooted ultimately leads her to wonder why people were "disinheriting their own people and future generations" (166). This is where I locate the core of Maathai's cultural philosophy of the environment and its implication for our conception of justice and human rights. She turns the vicious circle of cultural rootlessness-lack of care for oneself and the environment-into a virtuous circle of care for the same. She writes:

Through the analysis of the intersections of culture, the degradation of the environment, and political corruption, I realized it was necessary to enlarge the Green Belt Movement's conception of conservation to include a recognition of cultural heritage and the consequences of its loss.

Now, with the knowledge that there is a logical connection between being culturally uprooted and disinheriting future generations, Maathai established 
seminars that "allow individuals to deepen their sense of self-knowledge and realize that to care for the environment is to take care of themselves and their children - that in healing the earth they are healing themselves" (Maathai 2009:170). She introduced a concept, kwimenya, "which means being responsible oneself" (170). But responsibility for oneself must be coupled with the readiness to hold "leaders responsible as well - in other words, not only protecting the soil on your own land and conserving nearby forests, but also demanding that the government protect the country's soil and forests from degradation and exploitation" (170-171). In Maathai, therefore, meaning is like a circle that runs from culture to personal care, care for the other/society, and care for the next generation. I call it a hermeneutic circle of care that teaches us that responsibility for oneself must be tied to the environment and our fellow humans in order for it to be truly meaningful. The reverse is obviously the case. These three - the self, the other/society, and the environment - are all tied together in what I identify as Maathai's environmental political philosophy. Maathai's notion of care helps us to interpret her reading of justice and human rights. Human rights is better protected when we encourage people's dignity by proactively caring about and for them. Humans hardly abuse what they care about. In Maathai, the ordinary virtues, especially care for others, blossom into a thick conception of rights of (wo) man, and finally into a political act, a quest for justice.

It is befitting to conclude this meditation with the words and ideas of the Dalai Lama and Desmond Tutu; I do so in the belief that their ideas, especially about the environment, form a persuasive moral argument for environmental protection and human rights. For the Dalai Lama (2010:16), humans have strayed and have failed to see the essential common relationship of all things. For this, the earth is showing us indications that we have erred. To counter the practices that constituted the error, therefore:

[W] can teach ourselves to be more aware of our own mutual dependence. Every sentient being wants happiness instead of pain. So we share a common basic feeling. We can develop right action to help the Earth and teach others based on a better motivation. Therefore, I always speak of the importance of developing a genuine sense of universal responsibility.

I equate the Dalai Lama's notion of universal responsibility with Maathai's hermeneutic circle of care. Like Maathai, the Dalai Lama emphasizes the moral obligation of the present generation to relate to the next generation as if it were already present. He states:

Furthermore, as people alive today, we must consider future generations: a clean environment is a human right like any other. It is therefore part of our responsibility toward others to ensure that the world we pass on is as healthy as when we found it, if not healthier. 
In the same line of thinking, Desmond Tutu (2010:xiv) states that "[i]n matters of climate change, as in all aspects of our lives, our obligation is clear: we must do unto others as we would wish them to do unto us." It is instructive that Tutu locates care for the environment at the center of what has been universally accepted as the standard of all morality: the Golden Rule, versions of which are found in all cultures.

Maathai, the Dalai Lama, and Tutu, three of the better-known moral icons of our times, present us with a planetary moral consciousness, the central idea of which is also traceable to the UDHR; they make us aware of the global nature of our local ethics. This enhances the argument that environmentalism is a moral issue that sits at the core of humanity's moral framework. To care for the environment is a universal act that is, at the same time, patently individualistic. It is the best example of a fundamental moral act because it is intrinsically good, universal, and particular at the same time.

\section{The environmentalism of the colonized}

My interest in the environment as a human right issue centers on Rob Nixon's apt formulation of the relationship between industrialized nations and less developed nations in regard to the environment. Nixon calls the impact of the industrialized world's reckless exploitation of the less developed nations "slow violence" because the pollution that arises therefrom subjects the people in the less developed nations to a form of death that is barely noticed because it lacks spectacle. But the reckless exploitation reveals more than mere greed; it exposes a gross abuse of human rights that borders on mass murder. I consider two fairly well-known cases.

First, in 1991, the chief economist of the World Bank, Lawrence Summers, issued a memo in which he proposed that the industrialized nations should send their dirty industries to the less developed nations. He produced justifications based on pure reason, or the so-called rational choice argument. For him, the industrialized nations had too much pollution, whereas the less developed nations had too little of it; the West has a high life expectancy, whereas the less developed nations had low life expectancy. Given that the Third World has low life expectancy, sending them dirty industries would not make much (economic) difference, but it would cost much to care for lives in the West given their high life expectancy. He states: "Dirty" Industries: Just between you and me, shouldn't the World Bank be encouraging MORE migration of the dirty industries to the LDCs [Less Developed Countries]?" (The Whirled Bank Group 1991). Being the efficient economics professor he is known to be, he dismisses the anticipated, largely moral argument against his proposal thus:

The problem with the arguments against all of these proposals for more pollution in LDCs (intrinsic rights to certain goods, moral reasons, social concerns, lack of adequate markets, etc.) could be turned around and used more or less effectively against every Bank proposal for liberalization.

(The Whirled Bank Group) 
It is remarkable that Summers, ostensibly a liberal thinker, who served in both the Clinton and Obama administrations, dismissed what many consider to be some of the registers of humanity's moral frameworks such as intrinsic rights to certain goods, social rights, and moral reasons. But perhaps when it comes to the relationship between the West and the rest of us, the difference between conservatives and liberals in the West diminishes to a minimal level. Summers' memo is one case of the West having little regard for the well-being and human rights of the people in developing countries, their erstwhile colonies.

The second case is even more sinister. In 2006, a multinational company, Trafigura, dumped highly toxic waste in eleven unsecured sites in Abidjan City, Ivory Coast. In the following days and weeks, thousands of people exhibited signs of poisoning. According to Amnesty International, about 100,000 people were exposed to varying degrees of health hazards (Amnesty International). It is tragic enough that toxic waste is dumped anywhere in the world; it is more so when the waste in question had been rejected by Europe and any other part of the world the company had wanted to use to properly dispose of it (Lewis 2012). Why then did it have to be dumped in Africa, without taking care to protect the population? What does that say about how others see African humanity and how Africans, who accepted the waste, view their own lives?

The Brazilian minister of the environment, José Lutzenberger, highlights the problem in Lawrence Summers' thinking thus:

Your reasoning is perfectly logical but totally insane.... Your thoughts [provide] a concrete example of the unbelievable alienation, reductionist thinking, social ruthlessness and the arrogant ignorance of many conventional "economists" concerning the nature of the world we live in.

(The Whirled Bank Group)

I am drawn to two important issues in Lutzenberger's critique. One is that Summers' thinking is perfectly logical; the other is that it is reductionist and socially ruthless and indicates arrogance toward the nature of the world we live in-both of which are intertwined. By the phrase, "the nature of the world we live in," Lutzenberger is reasoning from the standpoint that we as humans cannot function without some kind of moral framework. We are essentially rational beings, and morality is part of our nature as rational beings. Of course, it is one thing not to have compassion for others; it is quite another to propose an action that would actively lead to their death. I think that Summers' thinking goes far beyond a simple lack of compassion for a people he did not know.

Judging from Summers' revelation of the knowledge of the consequences of his proposal, it is safe to say that any harmful consequence resulting from the decisions to send toxic waste or dirty industries to a defenseless group of people is premeditated. It is therefore a direct assault on not only the 
people's human rights but also their ultimate right to exist. To appreciate the moral magnitude of this situation, we consider the concept of "slow violence" a bit more closely. By slow violence, Nixon (2011:2) means:

a violence that occurs gradually and out of sight, a violence of delayed destruction that is dispersed across time and space, an attritional violence that is typically not viewed as violence at all. Violence is customarily conceived as an event or action that is immediate in time, explosive and spectacular in space, and as erupting into instant sensational visibility.

Violence does not have to be physical; it can also be psychological or verbal. In this regard, anything that intentionally hampers the normal course of a life is violent. We must recognize the importance of Nixon's admission that environmental pollution-especially that resulting from the thinking and vision of the powerful, such as that of Summers - is violence, albeit one that unfolds over time and is far removed from people's immediate attention. But the result is nonetheless the same. People experience gratuitous pain, and, in many cases, many people's lives are permanently disfigured. People die, through no fault of their own. People are displaced. Indeed, the more egregious aspect of that violence is in the thinking that considers some lives less valuable than others and therefore disposable. And this thinking is rational, which, of course, does not mean that it is moral.

Nixon's notion of slow violence allows us to see no difference between killing a people in an explosive, spectacular format and doing so in a subtle, sneaky way that unfolds over time. What counts is the premeditation, that is, the knowledge that one's action or decision will lead to the death of some people somewhere. He also speaks of displacement brought about by environmental pollution. But this displacement, in keeping with its nature as slow violence, is also not spectacular. This sort of displacement,

instead of referring solely to the movement of people from their places of belonging, refers rather to the loss of the land and resources beneath them, a loss that leaves communities stranded in a place stripped of the very characteristics that made it inhabitable.

Essentially, then, the local poor are dispossessed of their lands and are subjected to death by attrition. As I hope to make clear in the next section, this is precisely one of the situations in the Niger Delta region of Nigeria, a place in which all forms of violence converged to make the people the perfect example of the "wretched of the earth" (Fanon 1967).

The person, who is aware that sending dirty industries or toxic waste to the less developed nations, specifically to Africa, will diminish the people's lives even if it does not lead to death does not consider African lives to be 
valuable, to have dignity. This person considers such lives disposable. Neither does the African who receives such waste consider African life worthy of preservation. He or she lacks self-esteem, a requisite condition for dignity. The core of the moral issue with programmed environmental pollution is also the troubling colonial shadow of the thought process. The issue is that persons "A" do not consider persons "B" worthy of sufficient respect as to have a common moral framework with them. Neither do persons " $B$ " conceive of their world in the same moral framework. Perhaps the true source of the violence is in the fact that Summers failed to acknowledge the dignity of those to whom he wants to send dirty industries.

Summers' colonialist mindset is dangerous not only because it might produce death somewhere, but precisely because it is designed to do so and, therefore, goes to the heart of humanity's moral framework. It is unjust and immoral because it considers people in the Third World the way Nazi Germany considered Jews in the early part of the twentieth century: disposable. It is inevitable that this mindset be exposed and contested, for in it lies the origin of all forms of injustice in the world and abuses of humanity and others.

\section{The Niger Delta: writers and justice}

Environmental criticism has evolved from its initial focus on nature writing to questions of urgent existential import, questions that touch on whether a people survive or whether they are wiped out by another people's willful pollution of their living spaces. This shift in focus is generally understood as the second wave of environmental criticism in literature, and it preoccupies itself with ecological justice, bringing elements of postcolonial theory and race studies to bear on its self-understanding (Buell 2005). Literary discourse in Africa is gradually catching up with global development in this regard. Ogaga Okuyade's (2013) edited volume, Eco-critical Literature: Regreening African Landscapes, is a trailblazer, engaging critical perspectives on the importance of sustaining a symbiotic relationship between humans and their environment. Other works include Farieda Khan (2002) and Chinyere Nwahunanya (2011). Byron Caminero-Santangelo's Different Shades of Green: African Literature, Environmental Justice, and Political Ecology discusses social conflict, environmental change, and imperialism in Africa (Caminero-Santangelo 2014). As I have already pointed out, Cajetan Iheka's (2018) Naturalizing Africa: Ecological Violence, Agency, and Postcolonial Resistance in African Literature provides an enhanced discussion in this field, emphasizing the relationship between humans and the nonhuman world.

In discussing the selected works of African writers on environmentalism, I focus especially on the writers' perception of Africans as deserving of decent environment in which human flourishing is possible. It is therefore the question of justice in the form of restoration of the dignity of Africans in 
those spaces. Rob Nixon $(2011,14)$ believes that literature has a role to play in the condition of moral consciousness in regard to the environmental violence directed at the poor. He shares Aldo Leopold's belief that "we can be ethical only toward what we can see."

Nixon's ideas are in line with our interpretation of Aristotle's notion of tragedy (Chapter 1) as evincing pity and fear, that is, the capacity to extend our empathy to people in adverse situations they did not cause. "In a world permeated by insidious, yet unseen or imperceptible violence," Nixon argues, "imaginative writing can help make the unapparent appear, making it accessible and tangible by humanizing drawn-out threats inaccessible to the immediate senses" (15). Nixon argues that writers who witness the manifestations of slow violence have a moral obligation to bear testimony; they must uncover the degree of violence that the modern economy in its insidious ways has chosen to cover. As I sought to make clear in Chapter 1, narratives bring others closer to us and urge us to respond to the people's condition. In regard to those affected by ecological violence, it places them within the sphere of our empathy so that they are no longer an undifferentiated, amorphous group; rather, they become those who feel pain and pleasure just as we do. This special function of presenting the otherwise distant others to us is precisely where Njabulo Ndebele's notion of the ordinary plays a vital role. In order for any writing to imitate the kind of moral consciousness of which we speak and provoke a demand for justice, the writer must focus on the ordinary, that is, the practice of everyday life. Any attempt at polemic or protest writing surely fails to expose the ordinary life of people and with it the effects of other people's decisions on their fellow humans.

In Remnants of Auschwitz: The Witness and the Archive, Giorgio Agamben (1999:156) argues that it is a moral obligation for those who have a voice to speak for the voiceless. Describing the bodies of the Jews in Auschwitz who were so debilitated by hunger and sickness that they resembled the living dead, "the overcomatose person and the neomort attached to lifesupport systems today," Agamben notes that they could not bear witness to the horrors that were visited on them. Most of them ended in the gas chamber, anyway. Even though they were the perfect witnesses of the evils of the Holocaust, the only way they can speak is through the survivor, whose authority "consists in his capacity to speak solely in the name of an incapacity to speak - that is, in his or her being a subject" (156). Bearing witness is a moral obligation because it restores dignity to those who have been denied such. Agamben argues that

it is because there is testimony only where there is an impossibility of speaking, because there is a witness only where there has been desubjectification, that the Muselmann is the complete witness and that the survivor and the Muselmann cannot be split apart. 
In regard to the victims of violence such as in the Niger Delta, those who perished speak through those who write about them. Those who write about them, on the other hand, do so because of their belief in our common humanity. They write to call the attention of all to the moral frameworks that make us what we are: rational, vulnerable beings; they write not only to expose the horror of the violence slowly unfolding in their world but also to restore the dignity of the dead and the dying.

Nigeria is one of the ten largest producers of crude oil in the world and surely the largest in Africa. It is estimated that up to $70 \%$ of the crude oil produced by Nigeria comes from the Niger Delta, which is also one of the most environmentally degraded areas in the world. Crude oil was discovered in 1956 in Oloibiri, and with its production came the inevitable negative effects on the environment: pollution. Given the small mass area and the closeness of villages to oil deposits, most oil wells are located close to communities, and gas flaring and dredged spoils are close to people's homes. Oil spills are also common.

Ken Saro-Wiwa is one of the most renowned names in the Niger Delta people's struggle for survival, and he is one of the first people to speak out against such pollution. In the early 1990s, he became one of the founding members of the Movement for the Survival of the Ogoni People (MOSOP), which advocated for the basic human rights of the Ogoni people. Not long after that, in 1994, he was arrested, imprisoned, and put to death by the then military Head of State, Sani Abacha. His book (Saro-Wiwa 1996), A Month and a Day: A Detention Diary, documents his activism and occupies an important place in the literature on the ecological violence in the Niger Delta. Numerous works have been devoted to Ken Saro-Wiwa, including Rob Nixon's groundbreaking book and others (Campbell 2002). There are a handful of novels of varying degrees of literary strength by writers from the Niger Delta devoted to exploring the ravages of oil exploration in the Niger Delta. These include Tanure Ojaide's The Activist (2006), Isidore Okpewho's Tides (1993), and Kaine Agary's Yellow-Yellow (2006). These narratives have received some scholarly attention. I am, however, going to discuss the poetry of some of these writers, especially given the paltry attention they have received so far. They include Gabriel Okara, Tanure Ojaide, Ogaga Ifowodo, and Nnimmo Bassey. My approach is to show the original condition and beauty of the environment, its devastation, and the poets' reaction to it. I conclude with a discussion of Helon Habila's novel, Oil on Water.

Gabriel Okara was born on April 21, 1921, in Bumodi (Ijaw ethnicity), in present-day Bayelsa State in the Niger Delta, Nigeria. Okara's poem, "The Call of the River Nun," was published in 1953, three years before oil was discovered in the Niger Delta. ${ }^{3}$ The first stanza, comprising three lines, holds the key to a magical longing that the poem orchestrates: "I hear your call! / I hear it far away; / I hear it break the circle of these crouching hills" (Wonyogi Blog 2009). The speaker obviously has a special bond with the river, so much so that he or she hears the river's voice break through the bending hills. We 
assume that the river is serene and must have provided the speaker immense pleasure. The speaker's joy and admiration seem to have gained another dimension because of the river's location between the hills. We have a picture of an awe-inspiring part of the beauty of that world, a world whose dignity is intact. The last line of the second stanza adds a new dimension to nature: "I hear it coming through; invoking the ghost of a child listening, where river birds hail your / silver-surfaced flow." Thus, we now know that the speaker had been a child who had had a close affinity with the river.

The last stanza connects the river's call with the call of the seabird. In what seems to be an exclamation of the speaker's smallness in the face of nature, the speaker declares, as if overwhelmed by the experience of the sublime, "O incomprehensible God!" Thus far, the poem presents nature as a living organism; it is to be assumed that there is a symbiotic relationship between it and the speaker, who is in awe of its magnificence, nature. We have, therefore, a river, hills, a child, and birds, all together in a relationship that evokes the legendary Garden of Eden, a place untouched by sin and greed. Okara shares a common attitude with the nineteenth-century European Romantic poets: awe and respect for nature. Like Wordsworth, he sings in praise of nature that restores his imagination and provides him tranquility. Indeed, as Emmanuel Egya Sule (2016:4) observes, "The connection of childhood to the river, very primal, organic and spiritual, is symbolic of the connection between humans and their environments, between culture and nature, between present and future."

Okara's poem gives us an idea of what will soon be lost in the Niger Delta when the harmonious relationship that exists between the individual and nature is disturbed by "man's dominion," to quote another Romantic poet, Robert Burns. In an interview granted to Sumaila Isah Umaisha, Okara stated that "[his recent poem] River Nun (III) is all about the rivers, but there are some changes to reflect the present realities" (Umaisha). By present realities, Okara means, among other things, the fact that Shell is dredging the river for oil. To fully understand the details of the present realities, we shall turn to another poet from that region: Tanure Ojaide.

Ojaide was born in 1948 to Urhobo parents in Agbon Kingdom of Delta State. He has won several national and international poetry awards, including the Commonwealth Poetry Prize for the Africa region in 1987. As if providing an adequate response to Okara's poem, he paints the new, presentday picture of the otherwise serene and awe-inspiring river of Okara's childhood, several decades after the publication of "The Call of the River Nun." The title of the poem, "Can I Still Call from the River Nun?" signals the acerbic mood of the speaker (Ojaide 2015:114). ${ }^{4}$ The rhetorical question is sarcastic and raises doubts about the condition of the river. Whereas the river is the protagonist in the original Okara poem, one that beckons to the child that used to play or work in it, in "Can I Still Call from the River Nun?" the protagonist is disillusioned by dramatic changes in the river. The first couplet, "Can I still call from the River Nun to the sea maids / lounging 
in the Atlantic to come to me for a party" establishes a link between the river - contained within a locality in the first poem - and the sea/the Atlantic Ocean, signifying the larger world. The speaker's reference to the ocean evokes the role of global trade, including that of humans. The speaker is duly aware that his or her world is no longer that pristine environment reserved for the indigenous people there. Globalization has affected it, and negatively too.

The doubt, or better, the sarcasm introduced in the title permeates the rest of the poem. The dubious persona extends the same question to the birds that sang in "The Call of the River Nun": "Can the river bird be heard and summoned / to perch and dance on the reed in the tide." The question extends to humans, flora, and fauna surrounding the River Nun. These include the fisherman who goes to work with songs, the iroko, mahogany, the warthog, the porcupine, "the fish population fondly called children of the gods." The speaker knows that the symbiotic relationship that used to exist between these things is gone. We are given clues as to what has unbalanced their ecosystem and has disturbed their agency. It is "the vagabond flares of raging gas" and "the black clouds of fumes blanketing the sky." These, of course, refer to the oil drilling taking place in and around the River Nun.

Human rights instantiates itself in the full exercise of agency; it is the recognition and appreciation of a person's moral sphere. In Okara's poem we saw nature as a living organism with agency, to the degree that it is in a symbiotic relationship with humans. In presenting the break in the harmonious relationship between man and nature, Ojaide suggests the abuse of dignity and moral sphere of the region; he therefore establishes a condition for our understanding of the abuse of human rights in the region. The penultimate stanza rounds off with a long question that evokes the one introduced in the title of the poem: "can the remnant population of the abused land still / live meaningful lives after the death of companions?" The question is not answered, which allows the reader to provide an answer. But it is important to note the words and phrases that seem to highlight the writer's concerns: "abused," "meaningful lives," and "death of companions." This is one of the ethical moments in the poem, the moment in which, as Sartre says in regard to the responsibility of the reader, the reader is asked to animate the injustices presented to him or her with indignation. Although it is never sure how readers will answer, the tenor suggests that the question will activate the readers' responsibility. Although the last stanza addresses the defenders of their homeland, the long question, however, is for the world invoked by the reference to the Atlantic. He raises questions about what the world has done to the inhabitants or why the world has turned a deaf ear to the people there. Can the whole world look on while humans, flora, and fauna surrounding the beautiful River Nun perish at the hands of oil explorers? The poet challenges the conscience of the world. He turns "The Call of the River Nun" into a clarion call for the River Nun and therefore bears testimony to the dying world. 
In another poem, "In the Omoja River," (Ojaide 2015:117) Ojaide completes the circle of dialogue he began with his response to Okara's "The Call of the River Nun." In this poem, the speaker reminds the reader of what had been before the oil exploration began in the region and what has been lost to pollution. The first two stanzas paint the same natural scene as Okara's poem. In the river, they washed their bodies and tools. In the river, they "listened to murmuring water / before taking tracks into the forest to pick fruits." The next five stanzas, all couplets, are a list of accusations against those who destroyed the environment - those who "pissed and pissed barrels of arsenic into the current" and those who "stripped and stripped the forest naked." The repetition of the verbs "piss" and "strip" underscores the premeditated violence unleashed on the virgin land. In the combination of these verbs, the poet alludes to the rape of his land, the abuse of the rights of the environment and of the people.

The last stanza captures the intensity of the anger that has fueled the whole poem. Sadly, this anger threatens to block the emergence of the reader's moral affinity. The anger draws attention to itself rather than the condition that caused it. Perhaps the poem could have gained more if it had concentrated on the details of what was lost rather than cursing those responsible. It would be the moral obligation of the reader to do or not do the cursing. Rather than be moved to seek to protect the vulnerable, the reader already feels that the forceful language of the poem does that. But this does not detract from the force of testimony that this preeminent poet of the Niger Delta bears on behalf of his silent and slowly dying world.

The next important poet of the Niger Delta, Ogaga Ifowodo, was born in 1966 in Oleh. Before becoming a poet, he had worked for eight years as a lawyer with the Civil Liberties Organization, Nigeria's premier human rights group. He was held under preventive detention for close to a year by the then military regime of General Sani Abacha because of his human rights activism.

The cover art of Ifowodo's poetry collection, Oil on Lamp, is eloquent in regard to the environmental pollution in the Niger Delta. In the background is a row of four pipelines, at the end of which a huge ball of yellow fire dances into the atmosphere. On the pipelines are clumps of white substances, obviously tapioca or other local foodstuff, spread in wide baskets. By the left-hand side of the pipelines are three women, two of whom are stooped toward the tapioca, seemingly turning it so it can dry. The picture is blood-curdling for several reasons, one of which is the gas flare that sends out poisonous gases into the air, close to the people's villages. The other is that the village women spread their foodstuff to be dried by the heat of the gas flare. The third is, of course, the many pipelines that crisscross the people's farms. All of these paint a picture of desolation and deprivation, a picture that leaves no doubt as to the status of the humans living there as dispensable. One is left to imagine the effects of the fumes that the women are breathing right there beside the glaring toxic fire. And of course, the soot 
from that fire will eventually settle on the foodstuff they are spreading out to dry. When one imagines the lifespan of these women one cannot but think of Rob Nixon's notion of slow violence, or of Lawrence Summers' implicit disregard for the people. The picture, therefore, elicits questions that should constitute the core of any civil society's moral framework: How can humans force other humans to live in such despicable conditions? What do we owe this people, as fellow humans who possess the same rights and dignities as we do? What is the worth of the lives of those who live in that region? The last question seems to be the core issue that the poetry collection engages.

The Niger Delta has experienced not only slow violence; it has faced conditions similar to and frequently worse than war. For example, as a result of the conflict in the Niger Delta over indigenous rights to oil resources and environmental protection, during which twelve Nigerian soldiers were killed by suspected militants from the Niger Delta, the then-president of Nigeria, Olusegun Obasanjo ordered the Nigerian military to quell the militant resistance. A military attack was carried out on November 20, 1999, in the Odi community of Bayelsa State. "The military invaded the community and indiscriminately attacked the unarmed civilian population, which, according to human rights organizations left not fewer than 2,500 people dead." (Igbonwelundu 2013). They were pacified. Another incident: On October 19, 1998, an oil pipeline exploded in the town of Jese, about 180 miles southeast of Lagos. It was said to have been caused by people siphoning oil from the pipeline. The inferno that ensued cost between 250 and 700 lives (Associated Press 1998). These two are but some of the subjects of the poems in The Oil Lamp (Ifowodo 2005). My discussion is rooted in the poem about the second incident.

The poem "Jese" provides, in fine-grained detail, an account of the Jese fire incident, in a manner that conforms with Njabulo Ndebele's notion of the ordinary. The first line, "It was the fourteenth month of the fuel crunch" (3), paints the usual political-economic situation in Nigeria. Most Nigerians have become used to the fact that Nigeria, the eleventh largest producer of crude oil in the world, is not able to assure a constant supply of fuel to its citizens. The situation seems even worse in the Niger Delta, the source of Nigeria's oil wealth. Their condition is compounded by the fact that thousands of pipelines crisscross their lands; in some cases, these pipelines, often several decades old and rusting, run across the villages. The speaker draws our attention to this fact, to how the lives in that space were considered disposable:

With old pipes corroded and cracked

By the heat of their burden-

With these pipelines in every corner of the people's environment, their fate seems to have been sealed, or in Rob Nixon's terms, the violence that would consume them has already been programmed. It is a ticking violence. 
The speaker presents us with four boys who might have made the discovery that sealed the fate of the town. They are "[f] our boys chasing rodents for the day's meal_-"We are not left with just this information. The speaker makes sure to include a comparison to the boys' "mates in cities where the pipes end" and who, instead of hunting for rodents, are in classes learning letters in song and rhyme (5). Ifowodo inserted this comparison to elicit questions about justice and therefore challenge the moral compass of his compatriots from other parts of Nigeria, far removed from the Niger Delta. Whereas children from other parts of Nigeria are busy learning for their future, the four boys who hunt rodents for a meal are the ones to discover what will eventually lead to their town's doom. Their hunt takes them to a broken pipe from which oil flows out, and "they hurried home to fetch pails and keg, // cups and funnels. It was the fourteenth month / of the fuel crunch" (6). Their discovery was a boon to the town, for soon there was light and "stoves and lamps burned again" (7). The repetition of the time period, the "fourteenth month of the fuel crunch," reminds the reader how the impoverished and misruled Nigerians measure time. Major events mark time in the people's consciousness: the time before the fuel crunch and the time after.

No one knows precisely what sparked the fire. As Giorgio Agamben states, the perfect witnesses of the horrors of Auschwitz were those who went through the gas chamber, those who took their truth to the grave and so could not bear testimony to the horror; they cannot speak. It is therefore the moral obligation of the survivors to bear testimony so that the experience of the dead will not be lost. Perhaps those who know the truth of the fire incident were incinerated. But Ifowodo has undertaken to speak on their behalf, and he touches the most sensitive part of the poem: the programmed violence in the Niger Delta. The speaker provides the details required to drive home the slow violence. The speaker describes the reactions of the victims of the fire incident, focusing on that of a child who sees her mother burn. The child is traumatized by her mother's hair, which glowed "like filaments of gold / Led by the venomous scene of charring bone, // the dripping and drying fat of breasts and buttocks" (11).

It is the function of the storyteller to provide details of a narrative; it is that of the reader to respond. In tune with Nixon's argument, regarding the role of writers in bringing the violence of environmental degradation to the consciousness of others, Ifowodo makes sure to dramatize the experience of victims' slow death and erasure in such a way that readers can no longer claim ignorance of the situation. The readers are then challenged relative to their appreciation of the common humanity they have with the victims of abuse. Ifowodo does it by focusing on the ordinary lives of the people in the Niger Delta. Sadly, what is ordinary in their lives is the violence visited upon them. To further drive home the moral impact of the narrative, the speaker relates the cries of the bereaved. A woman wails about the loss of 
her husband, who is "[a]t the bottom of the sea, the bottom of the sea." There are no fish for her soup. The fish are "[d]ead in the creeks, dead in the lakes." She blames oil for all that. "Oil is my curse, oil is our doom" (17).

The woman's wail is a cry sent out to the world. Will the world hear? The lack of assurance that the world will hear her is a testament to her vulnerability. The more vulnerable people are, the more acute is the appeal to others to respond and to be moved to help. We are moved to help because of our investment in the moral framework which our being as humans assumes. In this manner, Ifowodo displays his moral and human rights conviction grounded in his eight years' experience as a human rights lawyer. This poem is, of course, a different appeal to the moral sensibility of people than is in legal format.

In the concluding part of this section, I discuss a novel by a more accomplished Nigerian writer, Helon Habila, who is not from the Niger Delta, and whose testimony is no less compelling. Habila's novel, Oil on Water, articulates the moral case proposed by the above poems in an equally visceral form. Habila was born in November 1967 in Kaltungo, Gombe State, Nigeria, several hundreds of miles removed from the Niger Delta. Unlike the poets we have considered thus far, he is not ethnically associated with the Niger Delta. This, I think, adds an extra dimension to our moral inquiry, which is the necessity to bear testimony to denial of justice and the abuse of human rights in the Niger Delta, regardless of ethnic affinity.

In Oil on Water, Isabel Floode, the wife of a British oil executive, is kidnapped in the Niger Delta. Two journalists, Rufus and Zaq, set out to find her. They embark on a very dangerous journey that mirrors the lives of the residents of the oil-rich region, and they come face to face with the daily struggles of the people of the Niger Delta: the polluted environment, the brutality of the government soldiers, and the militants fighting to preserve their homeland. Although Habila belongs to the group of more accomplished contemporary African writers, his works have not received commensurate scholarly attention. Thanks to the growing interest in environmentalism in African literature, Oil on Water is now being discussed at conferences and symposia.

Nigerian literary scholar Emmanuel Egya Sule (2018: 98) argues that

[w]ith the structure of a coming-of-age narrative, wrapped in the dominant trope of journey-something of a movement from the known to the unknown-Oil on Water is better perceived as a militant statement, indeed action, on the environmental and human waste going on in the Niger Delta.

I read the narrative a bit less as a militant statement, or even much less as a coming-of-age story, than as an exposition of the senseless violence visited upon the people of the Niger Delta simply because they happen to live in a 
place rich in a mineral deposit on which the neocolonialist machinery has cast its eye. For that, therefore, they are considered expendable, as did Lawrence Summers the lives of the citizens of developing nations. My analysis of the novel focuses on the most important encounters that expose the brutal environmental realities of the region. I do so especially in view of examining the contours of slow violence and instances in which the dignity of individuals is trampled upon or ignored due to lack of ordinary virtues of care and respect for their moral space.

In the early pages of the novel, Zaq and Rufus are aware that even though their goal is to find the kidnapped wife of a British oil executive, their mission has a meaning that goes beyond finding the white woman; it has "a greater meaning" (Habila 2010:5). In another instance, the militant leader Henshaw confronts Zaq, who had told him that they are in search of a white woman kidnapped in the region. He asks,

Is that all you want from me, to tell you whether some foreign hostage is alive or not? Who is she in the context of the war that's going on out there, the hopes and ambitions being created and destroyed? Can't you see the larger picture?

Now we see two instances that capture the nature of the testimony that Habila is bearing about the people of the Niger Delta: "greater meaning" and "larger picture."

What, then, is that "greater meaning"? What is the "larger picture"? I argue that the phrases are Habila's way of drawing attention to the injustice that inheres in the people's condition. The greater meaning and the larger picture gesture toward justice. In the encounter between Zaq and Henshaw, part of the larger picture is that the colonialist mindset suggest that the life of a white woman is more important than the lives of the people of the Niger Delta and that of their environment. The colonialist mentality is that part of the husband's injunction to Rufus and Zaq to find Isabel and that nothing should happen to her because she is "a British citizen" (32). The husband, James, does not grasp the full picture of what is happening in the Niger Delta. He does not seem to be in a position to grasp it because he is, well, a white man, who, as representative of the British colonial power, has never been in the position to appreciate the humanity of the colonized Africans. He implies then that Isabel's human dignity is more important than that of the people of the Niger Delta.

What greater meaning could there be than to respond to common humanity by narrating human rights abuses? It is perhaps not by accident that Zaq, the person who divined the deeper meaning of the journalists' journey into the depths of the Niger Delta, is described as one who philosophizes "over almost anything" (6). We take it that he is not one to be easily satisfied with a shallow perception of reality. He is therefore the one most suited to 
lead the reader to think about the context of life in the Niger Delta. True to Zaq's philosophical judgment, no sooner did they travel to the inner part of the troubled region in search of the kidnapped white woman than they encountered the devastations visited on the people by oil exploration in their homeland. They come across a deserted village, which is one of the most visible indications of such violence. Rufus says, "Behind one of the houses we found a chicken pen with about ten chickens inside, all dead and decomposing, the maggots trafficking beneath the feathers. We covered our noses and moved on to the next compound, but it wasn't much different" (9).

Rob Nixon speaks of the displacement of the poor natives in their land, due to pollution or the direct intervention of the government, as aspects of slow violence. Part of the contours of these forms of violence and human rights abuses is that people become refugees in their own land. Rufus and Zak take us to villages whose residents have either been terrorized into deserting their homes or have been killed. This is beyond slow violence; it is a lopsided war on the people. (Saro-Wiwa 1992). Less than halfway into the story we get a good picture of the world the two reporters are entering. It is a dying world, one in which the rivers no longer produce fish because they are toxic with oil spills. It is a world in which grasses no longer grow because oil spills have rendered the soil acidic. Rufus tells of what he had seen about the ecosystems:

We followed a bend in the river and in front of us we see dead birds draped over tree branches, their outstretched wings black and slick with pile; dead fish bobbed white-bellied between tree roots... The patch of grass growing by the water was suffocated by a film of oil, each blade covered with blotches like the liver spots on a smoker's hands.

(Habila 2010:9-10)

Ultimately, the challenges the narrative places before our moral eyes are the cost of the environmental degradation on humans, both directly and indirectly. Indirectly, when the environment is polluted beyond repair, people are forced to relocate. Directly, though, people catch various diseases or they die from the effects of toxic waste. Ironically, Zaq falls ill the moment he arrives in the region. His health deteriorates gradually; he is suffering from a kind of "hemorrhagic fever" that is nameless, but which he must have picked up "somewhere in these godforsaken waters." The doctor lets Rufus know that picking up a virus for such a hemorrhagic fever is easy (130). The mention of a kind of hemorrhagic fever does not go unnoticed by Rufus' hyperconscious mind.

Hemorrhagic fever is a metaphor of the people and their culture bleeding to death, a metaphor of slow death. He is dying slowly. His condition thus best dramatizes Rob Nixon's notion of slow violence. The doctor who diagnoses Zaq goes on to note what is responsible for the disease. He had been in those waters five years now, and he knows that it is "a dead place, a place for 
dying." To highlight what he meant by that, he points at the faraway orange sky and says, "Those damned flares" (131). The phrases "dead place" and "a place for dying" evoke the speaker in T.S. Eliot's "The Wasteland." Both Zaq and the speaker in "The Wasteland," speak of a place where nothing grows. And just as Eliot speaks to the moral post-World War I world, so does Habila seek to awaken awareness of human rights in his world.

It is ironic that Zaq, who goes to the Niger Delta to find greater, deeper meaning, loses his life there (234). He goes to die in the Niger Delta, to sacrifice his life so that the cry of the people there can be heard. Given that he is qualified as the thinker, one who searches for the deeper meaning of things, it seems apt to suggest that the region is where meaning goes to die. It is possibly where the moral awareness of his people might be born. In this regard, his death becomes highly symbolic; he becomes a sacrificial lamb, giving his life so that the world can see what is done to the people of the Niger Delta. This, I think, might sound too religious for some readers. I interpret it, though, in moral terms. Zaq considered the lives of the people of the Niger Delta worthy enough to invest his own life in a moral imperative, perhaps because he had imagined himself in their position. In his death, he demonstrated the ultimate form of solidarity. To him, no life is inferior to others. In his death and, of course the actions that led to it, he fulfilled the spirit of the first article of the Universal Declaration of Human Rights. In Zaq's life and death, the reader comes in close proximity with the people of the Niger Delta whose dignity had been denied them.

Those who kidnapped Isabel Floode did so in order to finance their resistance to oil exploration in their region and the pollution it brings about. The mastermind of the militant resistance tells Rufus to write "about the flares you see at night, and the oil on the water" (232). In other words, he entrusts the journalist with the task of revealing the concealed violence in the Niger Delta. In his thinking, the writer must bear testimony, in the manner Giorgio Agamben has mapped out, even while he engages in the gritty form of resistance; the writer must bring the people outside the Niger Delta in close proximity with the abuse of human rights taking place there. Eventually, Rufus finds Isabel Floode and discovers that she and James, her husband, have a complicated relationship. But that is secondary to the story. At that point in the story, Zaq's "greater meaning" has already been achieved. The reader has already been compelled to raise questions about the worth of human life in the Niger Delta.

The degree of violence unleashed in the Niger Delta has already been touched upon in my discussion of the poems. The implication of these forms of violence appears too obvious to be repeated in detail here, though it cannot be totally avoided. Of equal, if not deeper, relevance is the mindset that accompanies or even necessitates the violence. For instance, the doctor who is attached to the military camp reports on the impacts of toxins that the oil releases on the people. The Italian manager of the oil firm is friendly to him and informs him right away that he is now on their payroll and gives him the 
impression that his research will be of use. But when they do not take it seriously, he reports: "I thought they'd do something with my results, but they didn't. So, when people started dying I took blood samples and recorded the toxins in them, and this time I sent my results to the government" (145).

It is disturbing enough that the Italian manager would disregard the danger posed to the lives of the people of the Niger Delta; what is even worse is the utter disregard that the government has for the same lives. This recalls the story of the dumping of waste in Ivory Coast by Trafigura. What is the image and worth of the human persons living in that space in the minds of others? This question is as valid for the white man as it is for the black man in charge of lives there. There is, therefore, an open disdain for people's lives. It is not only the lack of ordinary virtues, but a manifestation of hatred, a belief in the disposability of human lives that are not ours.

Habila does not simply give us instances of the destruction of agency and moral space as reasons that force us our attention to injustice; he also directs our attention to how human rights could be restored and justice given to the victims. It is by nurturing a positive, caring attitude to humans, one that establishes them as possessing dignity, or as having agency in the first place. To restore people's human rights, we must see them through the prism of ordinary virtues of care, respect, compassion, and so on. For instance, Tamuno, who goes by the name Papa Michael, wants Zaq and Rufus to take his son, Michael, with them to the city because otherwise Michael has no future in that place. In a gesture of co-feeling, Zaq and Rufus discuss the option but discover it is a task they are ill-equipped to carry out (40-41). In this encounter, Zaq and Rufus demonstrate the alternative to the way in which the rest of the world regards the people of the Niger Delta. Zaq and Rufus encounter them as humans with dignity, who should be treated as such. This demonstrates their regard for the people's humanity; they are humans with agency, but who could not exercise it because of the condition of slow violence to which they had been subjected. Their relation to the people of the Niger Delta places premium on the positive, rather than the negative conception of morality and freedom; they demonstrate what ought to be done rather than what was not done or what evil had been done to the people.

Nnimmo Bassey titled the preface to his collection of poems, I Will Not Dance to Your Beat, "Reclaiming our humanity, our memory." This title is a fitting conclusion to our meditation on this section on bearing testimony. Bassey is one of Africa's leading advocates and campaigners for the environment and human rights. He "has stood up against the practices of multinational corporations in his country and the environmental devastation they leave behind destroying the lives and ignoring the rights of the local population" (African Success n.d.). In the preface, he reminds readers that "[e]verywhere we look we see pain, degradation and acts of man's inhumanity to man" (Bassey 2011:8). His words read as if he were interpreting Article 1 of the Universal Declaration of Human Rights. His collection of poems, therefore, is a response "to the prodigality of today's man" (8). 
The first five lines of his poem, "I will not dance to your beat," underline his unbending resolve to engage those who abuse other people's human rights and subject others to violence and death.

I will not dance to your beat

If you call plantations forests

I will not sing with you

If you privatize my water

I will confront you with my fists.

Bassey urges us in both his life and his poetry to fight environmental pollution because it is about our survival as people who share the same moral framework. He occupies a prominent position in the African imagination about environmentalism and human rights and bears testimony to the victims of slow, silent violence. It is, though, a different question whether one may be able to excite people's moral response with balled fists. If his poems do not rise to the level of aesthetic elegance that can be seen in those of Ogaga Ifowodo, they nonetheless convey a sense of urgency that equals his activism.

In conclusion, I return to the hypothetical situations I sketched in the prologue. It is fair to claim that these writers challenge us to imagine ourselves in the positions of the residents of the Niger Delta and to state how we would want the world to respond to our situation.

\section{Notes}

1 Some parts of this section appeared elsewhere (Eze 2019) in a different format.

2 Muselmann, Muslim in German is a term used by inmates of Auschwitz to designate those so debilitated by hunger and sickness that they resembled the living dead more than human beings.

3 The River Nun is a tributary of River Niger. It is when the Niger River splits in two, forming the Nun and Forcados rivers.

4 All further quotations from this poem refer to this page.

\section{References}

African Success: People Changing the Face of Africa. No Date. "Biography of Nnimmo BASSEY." http://www.africansuccess.org/visuFiche.php?lang= en\&id=944.

Agary, Kaine. 2006. Yellow-Yellow. Lagos: Dtalkshop.

Associated Press. 1998. "Oil Pipeline Blows Up in Nigeria, Killing 250 People." http://www.nytimes.com/1998/10/19/world/oil-pipeline-blows-up-in-nigeriakilling-250.html (Accessed September 21, 2019).

Bassey, Nnimmo. 2011. I Will Not Dance to Your Beat. Ibadan: Kraft Books Limited. Buell, Lawrence. 2005. The Future of Environmental Criticism. Malden, MA: Wiley-Blackwell. 
Caminero-Santangelo, Byron. 2014. Different Shades of Green: African Literature, Environmental Justice, and Political Ecology. Charlottesville, VA: University of Virginia Press.

Campbell, Marion. 2002. "Witnessing Death: Ken Saro-Wiwa and the Ogoni Crisis." Postcolonial Studies 5 (1): 39-49.

Dalai Lama. 2010. "A Question of Our Own Survival," pp. 15-20 in Moral Ground: Ethical Action for a Planet in Peril, edited by Kathleen Dean Moore and Michael P. Nelson. San Antonio, TX: Trinity University Press.

de Beer, Anna-Marie. 2015. "A Proper Woman, in the African Tradition": The Construction of Gender and Nationalism in Wangari Maathai's Autobiography "Unbowed" Tydskrif vir letterkunde: "n tydskrif vir Afrika-letterkunde 52 (1):144-154.

Eze, Chielozona. 2019. "The Aesthetics of Proximity and the Common Good." Cambridge Journal of Postcolonial Literary Inquiry 6 (2): 283-290.

Fanon, Frantz. 1967. Wretched of the Earth. Harmondsworth: Penguin Books.

Frankfurt, Harry. 2006. Taking Ourselves Seriously. Stanford, CA: Stanford University Press.

Habila, Helon. 2010. Oil on Water. New York: W. W. Norton.

Hayes, Diana. 2003. "Reflections on Slavery," pp. 65-75 in Change in Official Catholic Moral Teaching, edited by Charles E. Curran. Mahwah, NJ: Paulist Press.

Ifowodo, Ogaga. 2005. The Oil Lamp. Trenton, NJ: Africa World Press.

Iheka, Cajetan. 2017. "Pope Francis' Integral Ecology and Environmentalism for the Poor." Environmental Ethics 39 (3): 243-259.

Iheka, Cajetan. 2018. Naturalizing Africa: Ecological Violence, Agency, and Postcolonial Resistance in African Literature. Cambridge: Cambridge University Press.

Igbonwelundu, Precious. 2013. "Can Obasanjo, Others Be Tried for Odi Massacre?" http://thenationonlineng.net/can-obasanjo-others-be-tried-for-odi-massacre/.

Johnston, Barbara Rose, ed. 2016. Life and Death Matters: Human Rights, Environment, and Social Justice. New York: Routledge.

Khan, Farieda. 2002. "The Roots of Environmental Racism and the Rise of Environmental Justice in the 1990s," pp. 15-48 in Environmental Justice in South Africa, edited by David A. McDonald. Athens: Ohio University Press.

Lewis, Kim. 2012. "Toxic Dumping in Ivory Coast called Environmental Disaster." Voice of America, 26 September.

Maathai, Wangari. 2005. "Nobel Peace Prize Speech: Nobel Lecture, Oslo, 10 December 2004." Meridians: Feminism, Race, Transnationalism 6 (1): 195-201.

Maathai, Wangari. 2009. The Challenge for Africa. New York: Pantheon Books.

Moore, Kathleen Dean and Michael P. Nelson. 2010. Moral Ground: Ethical Action for a Planet in Peril. San Antonio, TX: Trinity University Press.

Nixon, Rob. 2011. Slow Violence and the Environmentalism of the Poor. Cambridge, MA: Harvard University Press.

Nwahunanya, Chinyere. 2011. "Introduction: From Boom to Doom-The Niger Delta in Contemporary Nigerian Literature," in From Boom to Doom: Protest and Conflict Resolution in the Literature of the Niger Delta, edited by Chinyere Nwahunanya. 27-36. New Owerri: Springfield Publishers Ltd.

Ojaide, Tanure. 2006. The Activist. Lagos: Farafina Press.

Ojaide, Tanure. 2015. Songs of Myself: Quartet. Ibadan: Kraft Books Limited.

Okpewho, Isidore. 1993. Tides. London: Longman.

Okuyade, Ogaga, ed. 2013. Eco-Critical Literature: Regreening African Landscapes. New York: American Heritage Press. 


\section{Ecological violence and quest for justice}

Pope, Carl. 2010. "Ethics as If Tomorrow Mattered," pp. 47-58 in Moral Ground: Ethical Action for a Planet in Peril, edited by Kathleen Dean Moore and Michael P. Nelson. San Antonio, TX: Trinity University Press.

Pope Francis. 2015. Laudato Si': Our Care for Our Common Home. www.laudatosi. com, 24 May.

Saro-Wiwa, Ken. 1992. Genocide in Nigeria: The Ogoni Tragedy. London: Saros International Publishers.

Saro-Wiwa, Ken. 1996. A Month and a Day: A Detention Diary. New York: Penguin Books.

Sule, Emmanuel Egya. 2016. "Nature and Environmentalism of the Poor: Ecopoetry from the Niger Delta Region of Nigeria." Journal of African Cultural Studies 28 (1): 1-12.

Sule, Emmanuel Egya. 2018. "Literary Militancy and Helon Habila’s Oil on Water." Research in African Literature 48 (4): 94-104.

Stockholm. 1972. "Declaration of the United Nations Conference on the Human Environment." https://www.google.com/search?client=firefox-b-1-d\&q=www. ipcc.ch $+\% \mathrm{E} 2 \% 80 \% \mathrm{BA}+$ apps $+\% \mathrm{E} 2 \% 80 \% \mathrm{BA}+$ njlite $+\% \mathrm{E} 2 \% 80 \% \mathrm{BA}+\mathrm{srex}+\%$ E2\%80\%BA+njlite_download (Accessed September 21, 2020).

The Whirled Bank Group. 1991. http://www.whirledbank.org/ourwords/summers. html (Accessed February 2, 2018).

Tutu, Desmond. 2010. "Foreword," pp. xiii-xiv in Moral Ground: Ethical Action for a Planet in Peril, edited by Kathleen Dean Moore and Michael P. Nelson. San Antonio, TX: Trinity University Press.

Umaisha, Sumaila Isah. No Date. "The Poet of the Nun River." http://www.africanwriting.com/six/gabrielokara.htm (Accessed February 7, 2018).

United Nations. No Date. Universal Declaration of Human Rights. http://www. un.org/en/universal-declaration-human-rights/.

UN Environment Programme. No Date. https://www.unep.org/about-unenvironment/why-does-un-environment-matter (Accessed September 21, 2020).

Wonyogi Blog. 2009. "The Call of the River Nun." https://woyingi.wordpress. com/2009/08/14/poem-the-call-of-the-river-nun-by-gabriel-okara/. 


\section{Mythic consciousness, witchcraft, and human rights abuses}

In May 2016, the Benue State Police (Nigeria) interrogated a seventeenyear-old Nigerian man named Agayo Iorzenda for killing his mother. In his defense, the young man stated:

I went to consult the oracle over my impotence and I was told that my mother used my manhood for witchcraft and rendered me impotent. She did not want me to be a man. So my friend advised me to kill her so as to use her blood to acquire spiritual powers that will help me become rich and do many other things. That was why I shot and killed her.

(Eboiyehi 2017:253)

Although most Africans would express shock at the fact of a young man killing his own mother, not many would doubt the witchcraft aspect of the story. Belief in the power of the occult is rife in Africa; it cuts across religious, ethnic, class, and educational groups. What strikes one is that most people, including practitioners of Christianity and Islam, believe in witchcraft but proceed to offer their Gods as an antidote to the power of the menacing witches. They therefore set out to liberate the individual by subjecting his or her body to some form of exorcism. Of importance to my discussion here is the human rights implications of such efforts to liberate the "infected bodies" from evil forces. The issue, therefore, is the different visions of the world, all rooted in competing mythologies and which have varying degrees of human rights implications, depending on the interpretation of the myth.

We have on the one hand the belief in witchcraft, rooted in African tradition; on the other hand, there is also the belief in, for example, the mystical power of Jesus Christ. What both of them have in common besides their root in mythology is the subsuming of the individual into some kind of belief system with its attendant ideology, which notoriously makes it difficult to consider individuals for who they are: bodies that feel pain. In this chapter, I seek to establish mythic consciousness as an enabling environment for witchcraft which I discuss as a dominant form of the abuse of human rights.

Witchcraft is not a uniquely African phenomenon. It has been practiced in Europe since as far back as recorded memory; its devastating effects, 
however, took official form in 1487 with the publication of a book called Malleus Maleficarum (The Hammer of Witches), by Heinrich Kramer (Mackay 2009). The book elevated sorcery and witchcraft to the status of heresy to be subjected to inquisition. The hunting down of so-called witches flourished during the Inquisition in Europe and the English colonies in the New World, up until the period of Enlightenment when science and reason began to shape official policies. In 1597, King James VI King of Scotland (later King James I of England) published a book on witchcraft called Daemonologie (Tyson 2011). When he became the king of England in 1603 he initiated a sweeping campaign to rid England of witches, thus creating one of the many instances of massive human rights abuses in European history. I feel compelled to provide this short bibliographical reference to underscore my intense desire to examine witchcraft as an aspect of humanity's imperfect effort to understand the mysteries of existence and to explain its devastating effect on human rights. Second, a casual glance at the studies of witchcraft in Africa conducted by mostly European anthropologists leaves the sour and wrongheaded impression that it is essentially African and that nothing could be done to extirpate that from the African nature.

The OED defines witchcraft as "The exercise of supernatural power supposed to be possessed by persons in league with the devil or evil spirits" (Simpson and Weiner 1989:439). This definition is obviously incomplete, but of significance to our discussion are two things: (1) a person exercising or affecting actions, and (2) recourse to supernatural powers. John Mbiti (1970:264), one of Africa's pioneer scholars of African religions, agrees with the definition, stating that

Witchcraft is a term used more popularly and broadly, to describe all sorts of evil employment of mystical power, generally in a secret fashion.... In popular usage the term "witchcraft" is employed to designate the harmful employment of mystical power in all its different manifestations.

Essentially, witchcraft is the belief that humans can exert agency and manipulate nature, but this agency is not direct; rather, it is already mediated by, well, another agent: the spirit. It is a received agency. It is different from spirit possession to the degree that the witch is believed to take the initiative to acquire spiritual or supernatural power in order to inflict harm. However, in some instances, it is believed that witchcraft can be inherited. So, the question is: who or what is really responsible for the exercise of certain actions or activities that are believed to manifest themselves in witchcraft?

E.E. Evans-Pritchard (1976), one of the earliest Western scholars on witchcraft in Africa, sees witchcraft as the belief in a mystical power innate in certain individuals and exercised by them to harm others. Dutch anthropologist Peter Geschiere (1997:12) contests the moral distinction most anthropologists have made in regard to the discourse of existence of 
witchcraft. For him, they reduce the distinction "to an unequivocal opposition between good and evil, even when the local terminology hardly lends itself to this." For him, "these terms are highly unfortunate and even misleading translations of African notions that often have a much wider range of meaning." Providing numerous examples given by his native informants in Cameroon, where he conducted his field research, he argues that witchcraft includes forces (evil or good) that humans appropriate in order to affect reality (10-11).

\section{Mythic consciousness and moral order}

Max Gluckman (1963:141), famous founder of the Manchester School of Anthropology, made a keen observation about the relationship between Africa and the West in the mid-twentieth century when he said in 1954 that "Africa has now been swept into the western world." This observation is even truer today. This is hardly new to any clear-eyed student of African history. For better or worse, Africa is now part of Western modernity. But Africa has yet to come to terms with this fact in that it is no longer in control of the world it used to know, and it is not fully at home in the strange new world. Africa is neither fully Western nor truly African in their traditional, purist senses. Analyzing African people's response to modernity and its threat to their lives, Gluckman states that:

Africans turned in several directions for supernatural aid. One trend was increasing reliance on another set of their beliefs - those in magic, in oracles, and in witchcraft... They also believed that individual misfortunes were due to the evil nature of fellow-men, witches and sorcerers, and they sought to combat these by magic.

Two things are at stake in this observation: one is ontological — the African people's place in the world, and their relation to God and the afterlife. The other is moral - the African person's relation to self and others. Essentially, these two-ontological and moral-aspects of being African are intertwined and largely explained through the modality of magic or witchcraft. ${ }^{1}$

Unlike the West, Africa has no recorded scientific explanation of the world. Much of their cosmology, as in the prescientific, pre-Enlightenment societies of the West, is embedded in their religions, which have no systematized theologies, unlike the more established religions such as Judaism, Christianity, Islam, Buddhism, Confucianism, and others. ${ }^{2}$ Africans explained misfortunes in moral terms and with recourse to supernatural forces and magic. Accidents or illnesses are never pure accidents or illnesses; they must be a result of evil machinations. According to Gluckman, the belief in the intercession of the supernatural world and its resultant will to control the world manifested itself acutely in the Kenyan Mau Mau rebellion. 
As the warriors of the Kenyan war of independence, the Mau Mau engaged in some form of rituals; they took oaths that bound them to the spilling of blood, engaging in taboo sex acts, and acts of bestiality and the threat to murder near kin. He sees these as the nihilistic "courage to revolt" (145). For Gluckman:

A cycle is set up as the oath-takers break taboos on sex, and menstrual blood, and so forth, and gain fresh energy. They are bound together, in shame and guilt, through the ranks of a disunited, shifting people. Mau Mau is dominantly a movement of despair, and uses a magic of despair.

Confronting the powerful British army, the Mau Mau resorted to those rituals as a last effort to snatch victory from the jaws of defeat, or perhaps simply to survive. These acts released the people from all inhibitions in order for them to devote themselves to the one goal of fighting the white man, who has proven to be far superior militarily. Their magic of despair is their total submission to, or indeed a result of, mythic consciousness. To be sure, what is interpreted as nihilistic might just be an instance of the limitations of one's skills and the helplessness that arises therefrom, intermixed with a stubborn will not to succumb to a condition considered intolerable. But it is also surely a manifestation of desperation, a desperate search for an explanation of the world that they no longer understood.

The Mau Mau's rituals are desperate perhaps because of their belief that those drastic measures would force the spirit world to intervene in the workings of the material world on their behalf. It is a form of self-flagellation the likes of which was practiced in the Catholic Church during the Middle Ages and which still exists in some forms of rituals of guilt today. Also, the European Middle Ages confronted through magic the phenomena that exceeded their epistemic horizon and threatened their existence. They subjected themselves to severe corporal punishments like fasting, bodily mortifications, and flogging. These flagellants, also explaining the world in moral terms, believed they could repel recurring plagues such as the Black Death by punishing themselves and others. But these explanations are prescientific, based on mythological thinking - that is, a specific kind of thought or explanation of the world rooted in stories or make-believe or in outright belief in witchcraft.

Cameroonian scholar of religion David T. Ngong recalls one of his encounters with witchcraft in Africa. When he was growing up in his village in Cameroon in the early 1980s, a friend of his died at about the age of ten. But this friend was not the only person to die in that family. Many other young people died successively. The oldest of them was barely twenty. Only one person would not die: the paterfamilias. It was rumored that he sacrificed the souls of his children so that he would become rich; the dead children would go on to work for him as zombies in the land of the dead while he 
reaped profit from their slave labor. The man, therefore, must have belonged to a secret cult called nyongo and must be practicing witchcraft. He must be a witch (warlock). Ngong observed that it did not make any difference that the man was not getting rich; at least, he was not any better off than all his poor neighbors. He still lived in a hut with plank walls. Yet, once the myth of his soul-devouring spiritual capability was planted in people's consciousness, they began to see him as a man in cahoots with the dark forces of witchcraft. When he eventually saved enough money and began to erect a small house with brick walls, that confirmed the village people's suspicion; his house was "burnt down by angry villagers," and he was consequently "exiled from the village" (Ngong 2012:145).

At least two things stand out in Professor Ngong's story. The first is the communal search for the explanation of the many deaths in the family; the second thing is the village people's easy recourse to stories or anecdotes for the explanation of phenomena that are obviously beyond their epistemic scope. They merely identified patterns and archetypes in their cultural memory. They relied on a mythic apprehension and interpretation of the world. The deaths could not just have happened by accident; there must be a cause, and that cause must be within the immediate world of the events and must be an evil force. Since an evil force cannot operate independently of persons, it must reside in a person who has welcomed it, a person who did not become prey to the force. It is easy to dismiss this thinking as a vestige of primitive societies, but a close look at its structure reveals that it is also how religious thinking works, and it is present in every culture of the world today.

To be sure, mythic consciousness is a particular form of reading of the world that relies on generous use of the imagination rather than on facts, and it expresses itself in many forms of mythopoeia such as anecdotes, legends, poetry, and literary works of fiction. The outstanding features of mythic conception of reality, as can be gleaned from the two stories above, are the absence of rigorous critical inquiry and the simplistic acceptance of the implied truth of anecdotes. As Kenneth Burke (1996:11) observes, "though mythos originally meant but 'word' (being the Homeric equivalent for logos), the important consideration for present purposes is that it came to mean a tale, story, fable, a narrative form." Myths are ahistorical, for they have no certain author; they explain matters by means of stories that explain things beyond the immediate scientific, factual horizon of the people.

The fact that mythic consciousness relies on fiction does not make its interpretation of reality false, but neither does it make it true. Like a work of fiction, its truth is different, requiring mediation. It can still make claims about the human condition, even if its details are not factual. Ernst Cassirer provides some characteristics of mythic apprehension of reality as follows:

(1) a feeling of sympathetic response to the world, dominating logical responses and perception of empirical cause-and-effect relationships; (2) a sense of the unbroken continuity and interconnectedness of everything 
in the world; (3) metamorphosis; (4) an experience of time into which linear progression does not enter, and the separate segments of timepast, present, and future - fuse into each other simultaneously.

(Jones 1975:6-7)

Understood in a simpler form, Cassirer is saying that mythic apprehension exhibits affective reception of the world that defies the logic of cause of effect; secondly, there is an amorphous interrelatedness of everything, and then a cyclical rather than linear interpretation of time. Of relevance to my inquiry is the notion of generous interpretation of the world that goes against the senses or factual cause and effect. In most cases, there is an overreliance on extrasensory perception or even on the supernatural world for interpretation of material reality. In some cases, there is a blunt refusal to see factual evidence, perhaps because of pure ignorance or the emotional need for confirmation bias. For example, when the male members of a particular family lose their lives before they reach the age of thirty, the family may find it difficult to accept that there is, for example, a congenital disease that runs through the family DNA and is passed on from father to sons. A suggestion that the cause might lie in their neighbor's evil intentions or their ancestors' anger might be more appealing to their religious, cultural, or ritual disposition. It is precisely prescientific because the people have no idea of the complex biochemical process in the human body called DNA.

The dangerous aspect of mythology as a means of explaining immediate reality of moral consequence is that it cannot be challenged because it is not rooted in something logically provable or challengeable, just as it is difficult if not impossible to challenge the existence or nonexistence of God.

According to Joseph Campbell, myths serve four functions: metaphysical, sociological, cosmological, and moral (pedagogical). Myths provide cultural frameworks for people to educate their young; they are generally guidelines for coping with the passage from one stage of life to another. I am particularly interested here in the sociological function, which according to Campbell (2001:31) is for:

supporting and validating a certain social order. And here's where the myths vary enormously from place to place. You can have a whole mythology for polygamy, a whole mythology for monogamy. Either's okay. It depends on where you are. It is this sociological function of myth that has taken over in our world.

Mythology preserves the conventional knowledge and order of the world because its origin is unknown. It is therefore no surprise that those who benefit from the status quo in any society are usually vehemently against new knowledge, either from science or a counternarrative. It is in this way that original mythology functions as a technology of power-a way of preserving power in the hands of those who benefit from it. This is mostly the 
case when that myth is put into the canon of knowledge or transmitted as dogma. Thus, in most cases, myths can be used to explain the world according to one's ideological bias. What is gained from this type of interpretation cannot be called knowledge in the strict use of the term, but this is beside the point. The point is that it becomes people's lifeworld and assumes a permanent place in the community's cosmology. ${ }^{3}$

As a form of entertainment, myths are purely harmless, and mythic consciousness often helps to expand the imagination. In some cases, however, people take myths as literal truth, and these myths thus control people's ethical disposition. A famous and undying example is the myth of the Fall of Man in the book of Genesis. Adam and Eve, purely fictional characters, morphed in the Judeo-Christian and Islamic imagination into real humans through whom sin came into the world. That helped shape most men's perception of and relation to women as a sure source and vector of evil in the world.

Famous professor of religious studies Jan Bremmer (1983:301) writes about the scapegoat rituals in ancient Greece, which involved the ritual of sacrificing something such as a goat, a person, a slave, or somebody deemed guilty in order to save the rest. He states that in Athens,

in exceptional times, such as a drought or a famine, certain ugly people were selected and sacrificed ... at the Thargelia, a festival for Apollo, a man with white figs around his neck was expelled from the city as a purification for the men, and another man with black figs for the women.

This ritual is not restricted to the ancient Greeks. In the Old Testament there are several references to the scapegoat sacrifice, Leviticus 16: 10: "But the goat chosen by lot as the scapegoat shall be presented alive before the LORD to be used for making atonement by sending it into the wilderness as a scapegoat."

According to René Girard (1989:25), "all myths have their roots in real acts of violence against real victims." At first, this claim seems untenable, especially given that there are also other myths that have nothing to do with violence. In terms of the primitive search for moral order, however, it appears that there will always be some form of victim. Girard underscores the consciousness behind the act of scapegoating someone or something in society. The need to justify that act "is that which produces myths" (50). In ancient societies the threat of permanent violence is often averted when communities find a single victim upon whom they can purge their collective anger. Such violence is usually created by "fierce rivalries and sets members of the same family or social group at one another's throats" (Girard 1977:49). This definition is of critical importance in our understanding of witchcraft as a phenomenon that obtains among close relatives and neighbors. A society or community immersed in violence or crisis and could thus be facing its own demise seeks "to deflect upon a relatively indifferent victim, a 'sacrificeable' victim, the violence that would otherwise be vented on 
its members, the people it most desires to protect" (4). The exercise might appear irrational, but it has its own logic. To quell the collective conscience of society, therefore, it has to produce some metaphysical explanation in the form of narrative. In this case then, myth functions to proactively justify the expurgation of an otherwise innocent human. Once the myth takes root in the people's culture it becomes a self-justifying act. Nowhere is this as true as with the phenomenon of witchcraft.

According to Monica Wilson (1951:313), "witch beliefs are general in smallscale societies with inadequate control of their environment and dominated by personal relationships, societies in which people think in personal terms and seek personal causes for their misfortune." Peter Geschiere (1997:11) echoes Wilson's observations, stating that even in modern African cities with electricity and clean water and access to information, "witchcraft is supposed to arise, first of all, from the intimacy of the family and the home."

If the world's evil can be explained in moral terms, that evil can only be defeated through moral means. Correspondingly, Gluckman argues (1963:143),

both in South and in Central Africa there have emerged men who moved through the country with new medicines to cleanse the people of their witchcraft: many people, aware of their vicious feelings, admitted these and asked to be cleansed.

As in Professor Ngong's story, society or the group usually rallies together to identify and uproot the cause, the sacrificeable person.

\section{Witcheraft and modern Africa}

To capture the depth and breadth of mythic consciousness as it relates to witchcraft and its implications in the conception and practice of human rights in Africa today, I shall relate some more incidents from anthropologists and other scholars working on the topic. The first incident: In their popular essay on occultism and modern Africa, "Occult economies and the violence of abstraction: Notes from the South African postcolony," Jean Comaroff and John L. Comaroff (1999) relate a list of incomprehensible and inexplicable phenomena that took place in post-apartheid South Africa. These include: (a) the sale of human parts on the streets or open markets, (b) ritual murder and the alleged production of zombies, and (c) pyramid schemes. For the Comaroffs, these are manifestations of an occult economy, that is:

the deployment of magical means for material ends or, more expansively, the conjuring of wealth by resort to inherently mysterious techniques, techniques whose principles of operation are neither transparent nor explicable in conventional terms. These techniques, moreover, often involve the destruction of others and their capacity to create value. 
They argue that the occult economy draws on cultural elements of indigenous histories to assert itself as a part of millennial capitalism; it is an "odd fusion of the modern and the postmodern, of hope and hopelessness, of utility and futility, of promise and its perversions" (283). The Comaroffs underline the fact that the roots of this strange phenomena "do not lie simply in poverty or material deprivation, however cruel and unrelenting it may be." Rather, they are to be found in what Max Gluckman has characterized as "the Magic of Despair" (283). In their understanding, this despair is brought about by modernity, the people's inability to find their way in a neocapitalist economy. As I have pointed out earlier, Gluckman's notion of the magic of despair is helpful because it allows us to grasp Africans' sincere but blind effort to grapple with the overpowering presence of modernity and the global economy.

It is intriguing that the Comaroffs believe that South Africans' resorting to the sale of human parts for occult purposes is out of desperation to which the modern capitalist economy has subjected them. This claim deserves a closer analysis that ought to go beyond the implicit and deserved critique of the neoliberal world order that has surely unhinged the African world. So, the larger question is: why exactly do Africans believe that human body parts could under any circumstances yield money to any person who consumes it or uses it in any other form?

Second incident: In his book The Modernity of Witchcraft in Africa, Peter Geschiere relates stories of incidents of witchcraft. In one of his field studies in Cameroon, a woman who identified herself as a (benevolent) witch stated:

I have been driving all night. I drive a plane. We use the plane to transport food, rain and such from places of plenty to the Buea area. Very recently, white people have been attempting to take the plane from us. If I hadn't been so skillful, having piloted the plane for 30 years, they would have long gone with it.

(Geschiere 1997:3)

The story is interesting for a number of reasons, one of which is that an African witch would use a metaphor taken from Western science to explain a supposedly scientific feat of African witchery. Perhaps Geschiere chose to ignore the contradiction, or even to suspect that the informer might be saying what she believed the white man wanted to hear. He seems rather too eager to highlight potential registers of modernity in that aspect of African cosmology. He thus states that, rather than seeing witchcraft and sorcery as belonging to ancient traditions that people had believed will disappear with modernization, people should rather see them as part and parcel of modernization in Africa. He writes, "Throughout the continent, discourses on sorcery or witchcraft are intertwined, often in quite surprising ways, with modern changes. Nowadays, modern techniques and commodities, often of Western provenance, are central in rumors on the occult" (2). What is 
more surprising, according to Geschiere, is how witchcraft has been grafted onto politics and has been deployed as an apparatus "in the accumulation of wealth and power" (5). He echoes Max Gluckman's observation that the belief and practice of witchcraft in Africa "does not contradict science: indeed, it embraces science. For witches do their ill-deeds by using elephants to crush, snakes to poison, overturned canoes to drown, disease to kill their victims" (Gluckman 1963:142). There is nothing surprising in the fact that Africans practice witchcraft at the same time that they make use of the fruits of European modernity, whose workings they might not have studied or understood. It is more plausible, I think, to suggest that mythic consciousness simply deploys any available idioms, however contradictory, to craft its narrative.

Third incident: Like the Comaroffs and Geschiere, Julien Bonhomme (2012:207) lists incidents that are incomprehensible to the modern mind but seemingly normal in modern Africa. These include stories of penissnatching, in which "strangers are accused of stealing (or sometimes only shrinking) the genitals of other people during public encounter, often by just a simple handshake"; killer mobile phone numbers, which states "that receiving calls from certain phone numbers could instantly kill those who took the call, with blood pouring out of the mouth, nose, and ears" (208), and of deadly alms, meaning that person "A" could cast spell on person "B" by gifting person "B" with alms laced with a magical potion.

Like Geschiere, Bonhomme (210) suggests that

witchcraft, magic, and the occult are no longer regarded solely as a traditional heritage, but rather as inherently modern phenomena, which must be set back in the context of global flows of symbols and imageswhat Appadurai aptly calls "mediascapes."

To be sure, Bonhomme (225) interprets the three cases above in line with Gluckman's magic of despair as manifestations of societies dealing with the anxieties and encounters associated with the anonymity of modernity. There is, therefore, a common theme of encounters with a strange world or modernity either in its violent form, as with the Mau Mau, or in the form of capitalism, as in the Comaroffs' example, or in technology and the uncertain contours of society as a result of globalization and migration, as in Geschiere and Bonhomme.

The fourth incident: The Nigerian social anthropologist Friday Eboiyehi (2017:253) interviewed an elderly woman who had been ostracized by her community because she was suspected of having caused the death of her son, who had died in a car accident several miles away. She narrates:

I had only three children that God gave me. We were all living happily together until early last year when the youngest of them died in a ghastly motor accident on his way to Benin. When they brought his corpse, the 
elders in my village insisted that they must find out who was responsible for his untimely death. They called a witch doctor who accused me of using witchcraft to kill my own son because he has not been sending money to me. The whole village has since isolated me. My children too have abandoned me because they see me as the one bewitching them.

I am not interested in providing an overarching ethnological or anthropological interpretation of these events, as are the Comaroffs, Geschiere, and others, however much they seem to be peculiar to sub-Saharan Africa. I do not question the quality or content of any person's belief. Indeed, these instances might not be qualitatively better than the beliefs and practices of certain cults or sects in Christianity in America. It is not entirely out of place to suggest that mythic consciousness as exhibited in the instances listed above issues from the same part of the psyche that has birthed religious rituals: humanity's quest for meaning. It is one thing to have a magical attitude toward reality; it is another thing to have that relation negatively impact one's relationship with fellow human beings, as happens in some of the stories above. Indeed, my ultimate concern in this book is about this second aspect: the degree to which abstractions create environments that enable the abuse of human rights by first impeding access to reality and destroying interpersonal relationships. ${ }^{4}$

The reliance on abstraction or naked ignorance of the workings of the human body has immense human rights implications. It creates a situation similar to what Jean-Paul Sartre (1989) describes in his play No Exit, a situation in which people see one another as embodiments of evil. ${ }^{5}$ In African contexts, the resort to abstraction in dealing with one's body and in relating to other humans easily turns their space into hell. For one, it effectively blocks people's portals of empathy so that it becomes nearly impossible to imagine the pain of others, even that of close family members such as one's child.

\section{Nollywood, evangelical Christianity, and witchcraft}

An average African scholar familiar with Western colonialists' outright dismissal of African culture and even African humanity would heave a sigh of relief at reading contemporary Western anthropologists' nonjudgmental analysis of the phenomenon of witchcraft in Africa. Yet their hesitancy gives the probably misleading impression of acceptance. For example, in Geschiere's efforts not to dismiss African reality out of hand, he searches for fitting comparisons in the West with some manifestations of the occult or witchcraft in Africa. In Cameroon, the nganga, or who is often pejoratively called the witch doctor, is a person who is believed to have access to the spiritual realm and knows its secrets. This profession has different names among various African ethnicities: babalawo in Yoruba, dibia in Igbo. They too can be witches, but they are believed to be able to effectively arm other 
people with special powers to harm enemies or protect oneself against them. Referring to these people, Geschiere (1997:9) writes:

When I listened to my friends' speculations about the hidden role of the nganga (healers) and their arsenal of occult tools, which supposedly were decisive factors in regional and even national politics, I was often struck by the parallel with the role attributed to public relations experts in American politics (and increasingly in Europe as well).

Geschiere's suggestion about the parallel between both instances of political consultancy is not accurate. As David Ngong (2012:160) argues, "comparing the political role of the nganga to public relations experts in the West confuses planes of discourse in one important way: it confuses metaphysical and non-metaphysical planes of discourse." I strongly agree with Ngong's perceptive observation here. Indeed, the proper comparison would be the nganga/witch doctor and evangelical Christianity and their prayer ministry (Wilonsky 2015). ${ }^{6}$ The Holy Spirit is to American evangelicals what the unnamed spirit or power is to the world of African witchcraft.

I understand that it is not the job of Western anthropologists working on Africa to provide a robust critique of African reality; this is the obligation of African intellectuals. It is in this light that I am grateful to scholars such as David T. Ngong and Elias Bongmba (2001). I appreciate especially Ngong's notion of the two planes of discourse that Western anthropologists conflate in their assessment of the African condition: physical and metaphysical planes - a mistake they might never make in any judgment of Western societies. The issue with the African notion of witchcraft, the one that as Ngong states "stifles African imagination," is the simplistic recourse to the supernatural to explain sometimes easily observable natural phenomena. It is therefore a legitimating of arbitrary judgment and abstractions in relation to others. The easy recourse to abstraction has far-reaching consequences for the conception and exercise of human rights in Africa. Abstractions obliterate the details of everyday life (Ndebele 1986:149-150). I have argued elsewhere that abstractions are some of the easiest ways to avoid personal responsibility because they notoriously ignore the demands of the other's body (Eze 2016). Abstractions as essential elements of mythic consciousness manifest themselves in language, heritage, culture, tradition, religion, and human rights abuses. Because of its reliance on archetypes, mythic consciousness sees humans not as individuals but as representative of something else: their groups, evil forces.

It turns out therefore that mythic consciousness, which sustains the belief in the existence of evil forces and the ability to cleanse people of them, constitutes an enabling environment for abuse of human rights in Africa. African Christianity has not helped to break the cycle of magical thinking in Africa. Indeed, the opposite is the case; rather, it merely has given a "civilized" legitimation to often wild beliefs in evil forces. Correspondingly, Christianity 
has replaced African witchcraft with spirit possession, and the witch with the evangelist/exorcist. Christianity promises an antidote to the powers of Satan: the fire of the Holy Ghost. It does not seek to explain the world in common-sense terms because that would go against childlike faith in and a magical relationship to God, which are the basis of their profession.

In his study of the impact of belief in witchcraft in post-apartheid South African politics, Adam Ashforth states that given the ubiquity of the belief in witchcraft and the notion that it is always about an evil person out to get another person, there are thousands of healers who propose various therapies, both spiritual and temporal. Healing from the attack of witches is a booming business in South Africa. According to Ashforth (2005:8), a rough estimate of the practitioners of this kind of healing is about half-amillion. The anti-witch shrines and many Pentecostal healing ministries are both technologies of social and cultural power. Their priests seek to exert control over society through a calculated manipulation of the minds of society's most vulnerable members. This power struggle has devastating consequences for the rights and dignities of people, especially those of women, children, and individuals of alternative sexualities and genders who are seen as abodes of evil. In the remaining sections of this chapter, I shall examine the appropriation of mythic consciousness in Nigerian popular films and its human rights implications.

In the twenty-first-century Africa, no other form of narrative better symbolizes mythic consciousness than the cheap video-to-film movies massively produced, especially in Nigeria, popularly known as Nollywood and which began in the 1990s. Uchenna Onuzulike argues that the whole Nollywood phenomena began with the movie Living in Bondage, produced by Ken Nnebue in 1992. For him, "the film set the pace for the emergence of Nollywood. Videofilm has become an important mode of apprehending reality and illusion in contemporary Africa. Nollywood is a vehicle through which Nigerian cultural heritage is represented" (2009:178). In the film, a young couple, Andy and Merit Okeke, are facing challenges in life, including sudden poverty. Andy is desperate to become rich by all means; he joins a satanic cult, in which members have to sacrifice the person they love most in a ritual. For that they become immensely rich. Andy sacrifices Merit, who dies in hospital shortly after the ritual. Before her death, though, she places a curse on her husband for his betrayal. Though he is rich, he lives in bondage with the devil, and Merit's ghost haunts him. He wants to be released from his allegiance and seeks out a chief priest, who prescribes self-castration and blinding. Andy does not want to go along. He becomes deranged and lives as a vagrant under a bridge in Lagos. Tina, a former prostitute he had presented to the cult as a decoy, discovers him under the bridge and takes him to her church, where the evangelical priest delivers him from his bondage in the name of Jesus Christ.

The video, having tapped into the archetypes prevalent in the mythic consciousness of the culture, opened the floodgates to the production of 
hundreds of such films each month (Adesokan 2011; Jonathan Haynes 2016). As Nigerian scholar of literature and popular culture Paul Ugor (2016:3) has observed, Nollywood began

as young people's own attempt to interpret and gain control over an emerging chaotic postcolonial reality.... Nollywood thus emerged as a modest cultural platform that offered young but economically and socially disenfranchised youth the opportunity to formulate both personal and collective myths that not only captured their quotidian struggles in both rural and urban spaces, but also their desires and hopes for a good life.

From its humble beginnings, Nollywood has assumed a global dimension, and its films "are now being featured in international film festivals in Berlin, Montreal, Paris, New York, London, South Africa, and even the bi-annual African film festival (FESPACO), which is held in Ouagadougou, Burkina Faso" (4).

Ugor pays special attention to the film industry's “young creators and the lives of other young people in the stifling environment that gave birth to it" (6). It is noteworthy that Ugor has offered a sympathetic reading of the efforts of these video-film makers; they were forced to eke out means of sustenance in the chaotic, postcolonial, and neoliberal reality. This assessment does not imply that he is oblivious to the negative sides of the undertaking, but exploring the moral implications of the genre has not been within his purview. Indeed, much has been written about Nollywood's humble beginnings and its global reach, but not much has been done on how it has reshaped African religious and moral landscapes. As Uchenna Onuzulike (2009:181) has observed:

Nollywood videofilms demonstrate how Africans have incorporated Christianity into their culture. On the other hand, there are some conflicts as a result of the hybridization of African traditional religions and Christianity. Nigerian videofilms have confirmed those issues that resonate in African society such as spiritual warfare and conflicting religious philosophies.

Without a doubt, the opportunistic blending of elements of African traditional religions and Christianity manifested itself starkly in the absorption of their various mythologies about the nature of evil in the world. The various elements in these two religions merely reinforced in the African mind the dominance of mythic consciousness, as the practitioners of both religions have borrowed copiously from one another to craft a simplistic, binary moral world.

Although Nollywood might have begun as an effort by Nigerian youths to eke out a means of survival in the postcolonial modernity, it has become an 
easy road to wealth for many of its producers. It cares less for the aesthetic claims of the genre or the ethical and social implications of their art. Of course, the producers would argue that their concern had never been about the art itself but rather about pure economic motivation. This, to be sure, is no different from most Hollywood film productions. The difference between the consumers of Nollywood and Hollywood films is, however, immense. Most consumers in the West have appreciable aesthetic awareness to differentiate between art and life and to delineate the mediated truth of art. The same cannot be said about most African consumers of these myths.

According to Samuel Waje Kunhiyop, Nollywood videos have played a significant role in the spread of belief in witchcraft:

Though they are usually cheap and of poor quality, these movie videos are one of the most powerful promoters of belief and practice of occultism, witchcraft belief and practice, Spiritism and ancestral veneration. Movie directors and producers deliberately and intentionally portray and re-enact these beliefs in such a manner that they reconnect with African worldview on witchcraft.

(Kunhiyop 2016)

Many such videos litter the web. Some of them include "My Daughter Is a Witch," "The Little Witch and the Wicked School Teacher," and so on (Nwaonu n.d.). What they all have in common is the binary distinction between good and evil and a naïve judgment of the world that is characteristic of societies whose epistemic registers are still immersed in mythologies, whose judgment of the world is largely controlled by paradigms derived from religion (Onyinah 2009) To say this is surely not to fall into the trap of hasty and undifferentiated judgments made by Western ethnologists and colonialist explorers, who branded Africans as pre-logical and primitive.

Regardless of the above colonialist observations, one fairly accurate statement about Africa stands: A large proportion of the African population is still illiterate, both functionally and literally. The tradition of writing and documentation and critical interrogation of knowledge has not yet taken root in most parts of Africa. The other side of this truth is that much of the information guiding African lives is still largely oral, and even in institutions such as schools, churches, and governments, where official policies are written down, they are usually ignored by many, including the policymakers. There is no controlling authority from which official readings of myths or other forms of knowledge flow. In other words, there is no official canon out of which some form of rational discourse can issue. All this makes room for chaotic readings of reality and the reign of a mythic apprehension of reality in which Nollywood flourishes.

When myths are not subjected to informed interpretation, such as the biblical exegetes have done for the myths in the Bible, the result is usually an undifferentiated consumption of the narrative and a conflation of art 
with life. There is, therefore, especially regarding African interpretation of myths surrounding witchcraft, a naive judgment of the world that thrives on a simplistic binary perception of reality, especially the moral world. There is also a related belief in the triumph of good over evil, and this triumph is usually associated with Christianity, as if to cap off the hegemonic colonial conquest of Africa.

The naive reading of myths, the resultant binary moral judgment of the world, and the apocalyptic belief in the triumph of good over evil are a lethal mix in the African world. Children have been buried alive, scarred by acid, and poisoned because their parents or benefactors believed the children were instruments of evil forces, that they were witches. To inflict pain on the bodies of these children therefore is tantamount to destroying whatever forces resided in them. For example: Mary Sudnad is one of the many children accused of being witches. When she lost her youngest brother, a pastor told her mother it was because Mary was a witch. The mother invited three men to her house; they beat up Mary while Mary's father watched. After the beating, the men took Mary to a church for a deliverance. A day later, they took Mary to a bush with Mary's mother.

They picked poisonous "asiri" berries that were made into a draught and forced down Mary's throat. If that didn't kill her, her mother warned her, then it would be a barbed-wire hanging. Finally her mother threw boiling water and caustic soda over her head and body, and her father dumped his screaming daughter in a field. Drifting in and out of consciousness, she stayed near the house for a long time before finally slinking off into the bush. Mary was seven. She says she still doesn't feel safe.

(McVeigh 2007)

As Marc Ellison and Samuel Iwunze demonstrate in their insightful slide and video presentation on the consequences of witchcraft accusations, many of the pastors and prophets "have commoditized witchcraft-a product on the market whose power is reduced through costly exorcisms. They point to the scriptures to validate their prophecies - a verse from the bible that tell readers to "suffer not a witch to live" (Ellison and Iwunze 1018).

As I have already noted in the introductory chapter, in 2015, Anja Ringgren Lovén, a Danish aid worker, saved a two-year-old Nigerian boy whose mother had left him on the street to die "because his family thought he was a witch" (Osborne 2016). This is not an isolated incident. African aid workers regularly encounter similar human rights abuses. Women who fall out of favor with their husbands, or who assert their rights in their marital homes, are often suspected of possessing the powers of witchcraft. There are thousands of lesser-known cases. Further down, I discuss one such case in which modern mythmaking blends with moneymaking evangelicalism; I discuss Helen Ukpabio and her film End of the Wicked: A Witchcraft Movie. 
I examine the structure of one of her films with the knowledge that whatever human rights judgments we are able to make from them applies, without much qualification, to $90 \%$ of all the other films. I conclude the section with a discussion of a much more aesthetically pleasing film, I Am Not a Witch, which is also about witchcraft, but which provides a counternarrative to dominant Nollywood films.

Born in 1969, Helen Ukpabio is credited with popularizing the belief that children could be agents of the devil and could practice witchcraft. Her fame, or more accurately, notoriety rests on the fact that she deftly combines being an actress with being a prophetess. She is an evangelical Christian pastor, the founder and head of the African Evangelical franchise, Liberty Foundation Gospel Ministries, based in Calabar, Cross River State, Nigeria. She established her own film production industry to propagate her version of the evangelical mission. There is no fine line between art and life, between acting and being, and herein lies the beginning of confusion in the minds of naïve consumers of her films.

In "End of the Wicked: A Witchcraft Movie," a number of mostly preteen children are believed to have exited their bodies while asleep; their spirits assemble in a witches' coven where they are initiated into the secret world of witchcraft. They imbibe resistant and destructive character traits (Onigbogbogbo 2013a). The scene changes to a modern nuclear middle-class family living in a posh modern house. After initiation into the cult of witches, their boy Dave returns home and declares to his mother: "Mommy, I am a wizard." The mother does not believe it. She hushes him and sends him to his bedroom. The boy's father tells of his bad dream. We are shown a scene of child members of the secret occult. Their Lord, a preteen boy, instructs them to steal their parents' property and bring the stolen items to their witches' den. With the stolen things as a link to the families, the occult members can then directly torment the family. They, the children, are therefore the witches, who, possessing supernatural powers, can now effect evil in the real world. Dave, who had told his mother that he was a wizard, is singled out and admonished for having revealed his secret identity. He gets a new name: Jeneji. All the kids get "evil" character traits inculcated into them: the spirit of stubbornness, stealing, waywardness, lack of interest in school, unsteadiness, bad company. They have the power to break glasses and to cause fever to all members of their family. Soon enough, the families of these children begin to experience a series of misfortunes. Job termination, divorce, Dave's father loses his sight, Dave's mother abandons the family, and so on. The source of the scourge, the viewers know, are the children who possessed evil magic powers. Ukpabio, the evangelical preacher, of course, sets the stage for the intervention of the superior power of Christ. In Part II of the film, Ukpabio herself plays the pastor, who purges these children of their evil through the power of the Holy Ghost and Jesus the healer (Onigbogbogbo 2013b).

The plot is predictably simple and overly didactic, leaving nothing to the imagination. Rather, it is all calculated to instill horror, touching nearly 
all registers of mythic consciousness such as those mapped out by Ernst Cassirer above, especially the affective, rather than logical, reading of cause and effect. Ukpabio exploits the mythic apprehension of reality and superstitious beliefs, particularly those related to demonic possession and witchcraft. The beginning of the film is a display of amateurism in cinematography and reveals right away the producer's didactic intent: to dramatize the existence of the power of evil. We are presented with a panoply of badly stitched grotesque features intended to present a gothic narrative. The characters are seen only as symbolic of something larger. They are therefore not explored from multiple dimensions as humans are supposed to be. In Ndebele's famous formulation, they offer "a vast sense of presence without offering intimate knowledge" (Ndebele 1986:49).

Ukpabio's goal is to explain the source of evil, the manifestation of which haunts modern families. But what is troubling to a modern mind is that obvious cases of disability or illness are easily attributed to evil forces. Children's stubbornness, dyslexia, or obvious lack of interest in school are not seen as parts of any human character development; rather, their causes are rooted elsewhere. Ukpabio's mythic consciousness, which enables her to invent an explanation for difficult behavior patterns, seeks their solution in another myth, the myth of Jesus as the savior. Only Jesus Christ can deliver the possessed children from the stranglehold of the powers of the underworld.

Ukpabio's case demonstrates the triumph of Western myth over that articulated in Africa. What both of them have in common is the evasion of forensically demonstrable reality. Perhaps due to African people's limited knowledge world, simple cases of intransigence or a flaw in a child's development of character is interpreted as a handiwork of the devil. In some cases, precociousness in children is interpreted as a sign of evil and often beaten out of them. It goes without saying that Ukpabio and her ilk are emblematic of widespread human rights abuses that are often accommodated if not promoted in the name of Christianity. They make human rights abuses appear as if they are treating a sick person in the hospital.

\section{Narrative and the quest for justice}

I return to the "five-oranges" hypothetical situation I sketched in the preface and specifically to the scenario in which the boys deny the girls oranges with the explanation that the girls (Eve) were responsible for the fall of man. There are many ways the girls can respond to the myth that made boys deny them their oranges: They can keep on appealing to the boys' empathy. Or they can also remind them that another woman brought salvation to the world by giving birth to Jesus Christ. In this case, the girls cleverly use a myth to vanquish another myth and they get their oranges. As much as we might chuckle at the humor of the situation, that is, intriguingly enough, how the world works. Ideologies are born of narratives. The use of one myth 
to challenge another is precisely what Rungano Nyoni does with her wellregarded film, I Am Not a Witch.

Whereas Nollywood film production stands for the wild exercise of mythic consciousness and abuse of mythopoeic tradition in Africa, $I \mathrm{Am}$ Not a Witch demonstrates some understanding of the art of narrative. I Am Not a Witch is a satiric narration of the fate of those accused of witchcraft in Zambia. Shula, a preteen orphan girl, is accused of being a witch because she happens to be standing nearby when a woman who has just fetched water from the village well trips and falls. The woman blames Shula for her fate and reports the girl to the police. People no longer fetch water from the well for fear of being bewitched. Once this one particular probable cause of people's misfortunes has been identified, many village people come forward to accuse Shula of their own hard luck. For the safety of the community, she is taken to a witch camp, which consists of mostly elderly women, and which is cordoned off with a white ribbon. Shula is told that should she cut the ribbon and attempt to escape, she will be cursed and transformed into a goat. After Shula is taken to a real witch doctor, who tests whether she is a witch, with a predictable result, she accepts her fate as a witch perhaps because her survival instinct makes her grasp that resistance would only confirm people's suspicions. It would make her appear even more strange, which would have effectively removed her from the reach of human empathy (Nyoni 2018).

Of importance in our understanding of the environment of human rights is what Shula reveals about the humans she encounters. She is like a mirror that reflects the character of those she encounters back to them. Perhaps this is one of the greatest revelations in the narration. For example, she is declared government property and put under the guardianship of Mr. Banda, who works for the Ministry of Tourism and Traditional Beliefs. He seeks to exploit her for his own ends. On a television talk show, she is displayed in public and asked to demonstrate her gift, but she doesn't speak. The talk show host is dubious about the whole game. He poses an insightful question: "What if she's actually but just a child?" At that pronouncement, the camera pans to Shula; she is in tears, probably moved by the combined effects of her being put on display and what the talk show host has said. Indeed, the talk show host seems to make the judgment the viewers would have arrived at. No one speaks - not Mr. Banda or the talk show host or Shula. We are allowed to digest the import of that pronouncement. The same question could be extended to the other women accused of witchcraft. What if they're but just poor elderly women? What if their crime was that they were the wretched of the earth? What is perhaps even more shocking to the viewer is that even after this pronouncement, Shula is still taken back to the camp where tourists pay her visits and take pictures with her.

In Shula, we judge the character of those she meets. Their reactions reveal the far-reaching toxicity of the environment sustained by mythic consciousness. It is part of the success of the film as a good work of art that the 
question is no longer whether Shula is a witch; rather, we judge the reactions of people who engage with Shula on daily basis. In judging their reactions, we judge ours. We are enjoined to examine how we would have acted in such situations. The film fulfills what we might call Ndebele's aesthetic test of African narrative, one of which is whether the narrative provides us with intimate knowledge of its characters. When we see Shula in her natural environment, when we encounter her as a child, which she is, we feel we know her, and we relate to her. This is because we see her just as a child, and not as representative of anything. The film does not present a "vast sense of presence"; rather, it takes Shula's life as just another ordinary life.

As Katie Rife (2018) rightly observes, "I Am Not a Witch fits right into the cringe-comedy tradition, albeit on the more formally rigorous end." Indeed, the film is squarely a satire, an effort to mock in a lighthearted manner the absurdity of witchcraft beliefs. Nyoni tactfully interrogates the belief and practice of witcheraft in Africa, and she does so in a way that does not sound preachy. She declared in an interview: "I wanted to show Zambian humour and how we deal with tragic events" (Webb 2017). As she reveals, the witch camp that provided the background for the story "is based on real places Nyoni visited in Ghana and Zambia" (Rife 2018). Some of the items she used such as the spools of ribbon were taken from real life. She states, "There are places in Ghana where they paint a line and tell you that you can't go around it or else you'll die" (Webb 2017).

Nyoni provides a counternarrative and lays the palimpsest for how to engage the debilitations of mythical consciousness. She succeeds best when she gives a glimpse into Shula's pain. This comes best in the television show where Mr. Banda and the talk show host talk about Shula while she says nothing. The single teardrop from Shula's right eye speaks directly to the viewer. It shows Shula as a regular human being. That tear drop encapsulates the question: Am I not a human? In it Nyoni directs our attention to the simple basic human dignity.

Besides directing us to the basic issue of human dignity, Nyoni successfully renders into humor that aspect of African tragedy by bringing us to laughter at some point in the film. One of the ways she does so is by producing a jarring contrast between tradition and modernity. In the background are Vivaldi and Schubert, symbolic of European modernity, which play against a pre-modern, medieval background. A further clash with modernity arises when the government wants to use the services of Shula to determine the person who had stolen a man's dowry money. The suspects are lined up and Shula should point out the culprit. As a witch, she should have the power to do so. But she calls her grandmother for help: "They've lined up the suspect, but I don't know who it is." The grandmother answers: "The one who looks scared." She explains further. "It is the one who looks down at the ground." At this point there is no doubt in the viewer's mind that Shula is just but a little girl. All these present Shula as a regular human who demands that we engage with her as human. 


\section{Witchcraft and the common good}

In his discussion of justice and otherness in Africa, Nigerian philosopher Uchenna Okeja (2019:10) argues that the primary condition for justice in society is the unconditional acceptance of the humanity of the other. Justice is based on deliberation, which in itself is "contingent upon the intersubjective affirmation of a basic principle, namely, the principle of humanity." What then are the principles of humanity or perhaps the impediments to their fullest realization? The standard for recognizing the humanity of others is simple and straightforward, as laid out in Article I of the UNDHR: that the other is as fully endowed with dignity as I am and therefore deserving of the same respect and treatment as I am. This is the point at which a difficulty arises, for, in Okeja's thinking, justice is denied precisely at the point we see the other as inferior or not fully human. I contend that witchcraft accusations achieve a specific goal in this regard: They objectify the other by robbing him or her of their humanity. The other is seen as less human because he or she is thought to be at the service of a force that is essentially against humanity. Witchcraft denies the accused the opportunity to be part of the deliberative process. This is precisely because the accusation summarily turns the accused into a stranger and a danger. Okeja argues:

Constructions of otherness which make the recognition of the humanity of a people or an individual who should be part of the deliberative process, present a fundamental challenge to the deliberative model of justice for two reasons. The first is that the absence of cognitive equality nullifies the motive for deliberation. It transforms the process into a monologue of the powerful, making it essentially a performance that makes the powerless victims ... [the second is] the anti-communitarian nature of constructions of otherness.

Analyzing David T. Ngong's already cited story, Okeja argues that it would be impossible for the accused man, who was eventually banished from the village, to receive justice because he had already been branded as less than human. What is said of this man also goes for children accused of witchcraft. It is heartrending to read about a mother who abandoned her children because she believed them to be witches. But the truth is that no cruelty is unimaginable in human community under enabling conditions, one of which is what Okeja has referred to as the absence of cognitive equality. I understand Okeja as suggesting that justice is possible only where the ordinary virtues of co-feeling, care, tolerance, and so on are present. Without these virtues, no community would be able to function.

The examples of witcheraft accusations we have seen this far reveal a society in which ordinary virtues such as compassion, fairness, love, empathy, 
and justice have been blunted by the ideology inherent in their mythic conception of reality. People's portals of empathy and fairness have been effectively blocked by the overpowering effects of simplistic myth and abstractions. Elsewhere, I discussed the role of empathy in society and how it could be blocked (Eze 2016). Nazi Germany, apartheid South Africa, and the Jim Crow American South are the most obvious examples. Frans de Waal (2009:214) argues that

We sometimes deliberately shut the portal, such as when we suppress identification with a declared enemy group. We do so by removing their individuality, defining them as an anonymous mass of unpleasant, inferior specimens of a different taxonomic group.

Mythic consciousness blocks or at least blurs people's portals of empathy, precisely because of the absolutist binary modality of the narrative. And because it creates conditions that present humans in an abstracted condition, people are no longer seen as individuals with distinct feelings but rather as puppets. Presenting humans as mere symbols effectively puts the accused outside the range of people's empathy. Where empathy is not blocked by indoctrination or myths, it brings people back to the most basic form of bodily identification with others, regardless of race, sex, age, religious beliefs, and other forms of group identification.

Belief in witchcraft erodes trust and good will among people and ultimately destroys feelings for the common good. Many keen observers of witchcraft accusations in Africa have noted that they are manifestations of everyday strife within close-knit communities. As Monica Wilson (1951:312) has observed, "In Nyakyusa society friction is most likely between neighbors who live close together, and it is between them that accusations of witchcraft are most frequent. Both societies are polygynous, and, in both, accusations are fairly frequent between co-wives." Given the persistence of mutual suspicion among neighbors, there is hardly any ground for mutual deliberation on any issue and therefore no condition for justice in society. That further creates conditions for some kind of authoritarian assertion of personal opinion either from the eldest man or from a band of men. This situation arises largely due to the fact that the parties regard each other as inherently dangerous enemies. The condition described in the already cited Sartre's play, No Exit, takes place: Humans become hell to humans.

The obsession with purity and the urge to rid society of its bad apples give rise to conditions in which people project their own failures and weaknesses on others, partly in the belief that the accuser is considered better than the accused. People therefore produce what Girard calls a "sacrificeable" victim" (Girard 1977:4). Wilson draws an important comparison between witchcraft accusations in Africa and McCarthyism-campaign against 
alleged communists in the United States carried out under Senator Joseph McCarthy between 1950 and 1954. She raises important questions:

Are the witches but the primitive form of the scapegoat who is always with us? Are men with pythons in their bellies and those who ride baboons by night indeed a true parallel to the red agents of McCarthy's fevered dreams?

(Wilson 1951:313)

Economic professor Boris Gershman (2016:184-185) argues that belief in witchcraft also hampers society's economic growth primarily because it hinders

interpersonal trust, cooperation, and social relations more generally. An overview of ethnographic case studies suggest that there are two main reasons for being suspicious, distrustful, and non-cooperative in a society with widespread witchcraft beliefs: the fear of bewitchment and the fear of witchcraft accusations.

This observation becomes all the more apparent in preliterate societies, where contracts are not written down and cannot be backed by the force of law. People depend much on the goodwill of their neighbors and that of the community. In situations where one party accuses the other party of witchcraft in order to get out of a mutual business contract, that destroys not only human interaction but also the possibility of both parties profiting from current or future business deals. It turns out therefore that given the above conditions, in societies in which belief in witchcraft flourishes and in which people mutually accuse one another, it becomes impossible to get people to think of or act toward the common good, or even to think of the common virtues of empathy and care. One hardly empathizes with the other whom he or she considers an actual or potential enemy.

The above considerations constitute not only the ethical consequence of widespread belief in witchcraft; they also gesture toward political implications, the most fundamental of which is the ability to conduct deliberation and to exercise justice.

\section{Notes}

1 We must guard against making any hasty general judgments about the so-called nature of Africans. We might ask ourselves why there has been an increase in religious fundamentalism and denial of obvious facts of science such as evolution and the spherical nature of the globe in America? Why has the flat earth society flourished?

2 With this I am passing no value judgment. As a person who grew up practicing Animism - traditional to my ethnicity, the Igbo - and as one who studied 
Catholic theology, I know the difference between these religions in terms of theology.

3 Until the phenomenon of sickle cell anemia became widely known in Africa (at least the part of Africa I come from) successive childhood deaths in families were attributed to supernatural forces primarily because the people had a limited knowledge about it. Presently potential couples test for their blood type for the probability of their offspring inheriting sickle cell.

4 Of course, it does not help that different churches now offer Christian solutions to the alleged occult attacks rather than explain what might be going on in people's lives.

5 In the play, three souls, Joseph Garcin, Inès Serrano, and Estelle Rigault, are condemned to hell because of their sins on earth. They are locked up in a mysterious valet, and they are at first surprised to learn that their hell is not a burning cauldron. But after staying with one another in the closed room for a long time they find one another unbearable and discover that hell is other people.

6 When I saw a host of Evangelical pastors laying their hands over Trump in 2015 to protect him from his liberal enemies, I saw in my mind's eyes African politicians seeking out ngangas, babalawos, or dibias for protection against the evil forces of their enemies.

\section{References}

Adesokan, Akin. 2011. Postcolonial Artists and Global Aesthetics. Bloomington: Indiana University Press.

Ashforth, Adam. 2005. Witchcraft, Violence, and Democracy in South Africa. Chicago, IL: The University of Chicago Press.

Bongmba, Elias Kifon, 2001. African Witchcraft and Otherness: A Philosophical and Theological Critique of Intersubjective Relations. Albany: State University of New York Press.

Bonhomme, Julien. 2012. "The Dangers of Anonymity: Witchcraft, Rumor, and Modernity in Africa.” HAU: Journal of Ethnographic Theory 2 (2): 205-233.

Bremmer, Jan. 1983. "Scapegoat Rituals in Ancient Greece." Harvard Studies in Classical Philology 87: 299-320.

Burke, Kenneth. 1996. "Myth, Poetry and Philosophy," pp. 283-306 in Literary Criticism and Myth, edited by Robert Segal. New York: Garland Publishing, Inc. Campbell, Joseph. 2001. The Power of Myth. New York. Broadway Books.

Comaroff, Jean and John L. Comaroff. 1999. "Occult Economies and the Violence of Abstraction: Notes from the South African Postcolony." American Ethnologist 2b (2): 279-303.

De Waal, Frans. 2009. The Age of Empathy: Nature's Lessons for a Kinder Society. New York: Harmony Books.

Eboiyehi, Friday A. 2017. "Convicted without Evidence: Elderly Women and Witchcraft Accusations in Contemporary Nigeria." Journal of International Women's Studies 18 (4): 247-265.

Ellison, Marc and Samuel Iwunze. 2018. "Suffer Not a Witch to Live." Aljazeera. https://interactive.aljazeera.com/aje/2018/suffer-not-a-witch-to-live/index.html\#1.

Evans-Pritchard, E. E. 1976. Witchcraft, Oracles, and Magic among the Azande. Clarendon, TX: Oxford University Press.

Eze, Chielozona. 2016. Ethics and Human Rights in Contemporary African Women's Literature. New York: Palgrave Macmillan. 
Gershman, Boris. 2016. "Witchcraft Beliefs and the Erosion of Social Capital: Evidence from Sub-Saharan Africa and beyond." Journal of Development Economics 120: $182-208$.

Geschiere, Peter. 1997. The Modernity of Witchcraft: Politics and the Occult in Postcolonial Africa. Charlottesville: The University of Virginia Press.

Girard, Rene. 1989. The Scapegoat. Baltimore, MD. Johns Hopkins University Press.

Girard, Rene. 1977. Violence and the Sacred. Translated by Patrick Gregory. Baltimore, MD: The Johns Hopkins University Press.

Gluckman, Max. 1963. Order and Rebellion in Tribal Africa. New York: The Free Press of Glencoe.

Haynes, Jonathan. 2016. Nollywood: The Creation of Nigerian Film Genres. Chicago, IL: University of Chicago Press.

Jones, James Land. 1975. Adam's Dream: Mythic Consciousness in Keats and Yeats. Athens: The University of Georgia Press.

Kunhiyop, Samuel Waje. 2016. The Role of Nollywood in Witchcraft Belief and Confessions. February 2, 2016. http://henrycenter.tiu.edu/2016/02/the-role-ofnollywood-in-witchcraft-belief-and-confessions/ (Accessed June 10, 2019).

Mackay, Christopher S. 2009. The Hammer of Witches: A Complete Translation of the Malleus Maleficarum. Cambridge: Cambridge University Press.

Mbiti, John S. 1970. African Religions and Philosophy. New York: Anchor Books.

McVeigh, Tracy. 2007. Children Are Targets of Nigerian Witch Hunt | World News | The Observer. London: Guardian. https://www.theguardian.com/world/2007/ dec/09/tracymcveigh.theobserver (Accessed April 5, 2019).

Ndebele, Njabulo S. 1986. "The Rediscovery of the Ordinary: Some New Writings in South Africa." Journal of Southern African Studies 12 (2): 143-157.

Ngong, David T. 2012. "Stifling the Imagination: A Critique of Anthropological and Religious Normalization of Witcheraft in Africa." African and Asian Studies 11(1-2): 144-181.

Nwaonu, Chiemelie Mischack. No date. My Daughter Is a Witch. https://www. youtube.com/watch?v=LgwGwgLJBEw (Accessed June 10, 2019).

Nyoni, Rungano. (2018). I am Not a Witch. https://www.amazon.com/gp/video/ detail/B07KLG6JPR/ref=atv_dl_rdr.

Okeja, Uchenna. 2019. "Justice through Deliberation and the Problem of Otherness." Angelaki: Journal of the Theoretical Humanities 24 (2): 10-21.

Onigbogbogbo, Tunji. 2013a. The End of the Wicked-Part One. https://www. youtube.com/watch?v=VRivyuU151Y (Accessed June 10, 2019).

Onigbogbogbo, Tunji. 2013b. The End of the Wicked-Part Two. https://www. youtube.com/watch?v=jA9Lg44jIKQ (Accessed September 10, 2020).

Onuzulike, Uchenna. 2009. "Nollywood: Nigerian Videofilms as a Cultural and Technological Hybridity” Intercultural Communication Studies XVIII (1): 178.

Osborne, Samuel. 2016. Two-year-old Nigerian Boy Accused of Being a Witch Rescued by Aid Workers. http://www.independent.co.uk/news/world/africa/two-yearold-nigerian-boy-accused-of-being-a-witch-rescued-by-aid-workers-a6875706. html (Accessed June 10, 2019).

Rife, Katie. 2018. "Tradition and Technology Collide in the Spellbinding, Bonedry Satire of I Am Not a Witch." AVFilm. https://film.avclub.com/tradition-andtechnology-collide-in-the-spellbinding-b-1828889737 (Accessed September 12, 2020). 


\section{Mythic consciousness and witchcraft}

Simpson, J. A. and E. S. C. Weiner. 1989. Oxford English Dictionary. Vol X. Oxford: Clarendon Press.

Tyson, Donald. 2011. The Demonology of King James I: Includes the Original Text of Daemonologie and News from Scotland Woodbury. Minnesota: Llewellyn Publications.

Ugor, Paul. 2016. Nollywood: Popular Culture and Narratives of Youth Struggles in Nigeria. Durham, NC: Carolina Academic Press, LLC.

Webb, Beth. 2017. "Rungano Nyoni: 'I Wanted to Show Zambian Humour and How We Deal with Tragic Events." Little White Lies. https://wlies.com/interviews/ rungano-nyoni-i-am-not-a-witch/ (Accessed September 12, 2020).

Wilonsky, Robert. 2015. "Donald Trump Meets with Religious Leaders, Including Robert Jeffress.” YouTube. https://www.youtube.com/watch?v=Uk4c2uoOF3o.

Wilson, Monica Hunter. 1951. "Witch Beliefs and Social Structure" American Journal of Sociology 56 (4): 307-313. 


\section{Barriers to being \\ Albinism, disability, and recognition}

As I hope to have made clear in Chapter 3, mythic apprehension of reality constitutes a major hindrance in interpersonal relationships because people interpret reality through the prism of magic and abstract beliefs rather than through the practice of the ordinary. In most cases, myths create and sustain a toxic environment that enables the abuse of human rights. Mythic apprehension of reality, which is often preserved in religious and cultural rituals, effectively shapes people's moral attitudes. For instance, many people of Abrahamic faiths relate to women based on the moral principles derived from the myth of the Fall of Man whereby women (Eve) brought about the fall of men (Adam) by luring them into sin. Women are always at fault. In such cases, in order to break the thrall of mythology, an appeal to the basic principles of common humanity becomes unavoidable. By this appeal to the common humanity, I mean that individuals need to be reminded that others have dignity and therefore must be treated the way we all would desire to be treated. But simple appeals are often not enough to maintain a world in which people's human rights are consistently respected. A vigorous campaign must be conducted to drive home the absolute necessity of maintaining the inviolability of the dignity of individuals, whether they are strangers, look strange, or are otherwise unknown to us. Thankfully, people are doing just that. I have also related Vicki Ntetema's undercover investigation of killings of people living with albinism in Tanzania, the Democratic Republic of Congo, Burundi, and Rwanda.

In this chapter, I discuss the condition of people living with albinism in Africa. I identify albinism as a disability that, like all disabilities, ought to elicit every decent person's compassionate attention. In my discussion, I translate this compassionate attention into the broader philosophically tinged notion of recognition and moral responsibility. The issue of disability as a subject of inquiry has not yet received the much-deserved attention by scholars of the African world. As I have already mentioned in the introductory chapter, Ato Quayson's Aesthetic Nervousness is to my knowledge the only work that engages it. Quayson examines disability in literature as an ethical issue. Disability fundamentally affects intersubjective relationships and forces readers to take an ethical position. Following in his footstep, 
I argue that disability calls on us to examine our notion of (social) justice, whether we accord vulnerable members of society the same dignity we claim for ourselves.

\section{Black people in white skin}

In one of the most poignant chapters of Black Skin, White Masks, titled "The Lived Experience of the Black Man," Frantz Fanon (2008:91) recounts the minor details of black people's encounter in Europe that negate their existence as humans. Such details include the simple gesture of a white child pointing at him, a black man, and declaring, "Maman, look, a Negro; I'm scared!" Fanon states that, like every other human, he came into this world eager to be, to live his life, and to "uncover the meaning of things," but at the moment of that encounter he became "an object among other objects" (89). The reason does not lie in his nature - that is, he is not predetermined by nature to be diminished or be frightened in the presence of others, as a prey would at the sight of a predator. Rather, his feeling of becoming an object is in the nature of the encounter between black and white in a racist environment. The black man has already been defined over the centuries with thousands of "anecdotes, and stories" (91) woven around him by the white man whose child pointed at him, stories that fixed him in an inferior category of being. The black skin is therefore not just a different shade of skin; it is a signifier, and the signified is embedded in the myths and anecdotes of which the child is fully aware. In pointing at the black man, the child pins him down with all the weight of history. The black man cannot fight back because the issue is not with the child; it is what the pointing finger stands for. Indeed, the battle, issuing from Hegel's master/slave dialectic (Hegel 1971:170-175), had already been won even before the black man encountered the child, and because of the lost battle, the black man has "difficulties in elaborating his body schema" in the white world. The image of his body "is solely negating.... All around the body reigns an atmosphere of certain uncertainty" (Fanon 2008:90).

Fanon echoes W.E.B. DuBois' notion of double consciousness - that is, according to DuBois (1996:5), a veil, "this sense of always looking at one's self through the eyes of others, of measuring one's soul by the tape of a world that looks on in amused contempt and pity." DuBois describes a condition in which the black person is split between two worlds: one in the presence of white people, the other when he is among black people. In each world, the black man never achieves full consciousness. For DuBois and Fanon, the white gaze erases the black body thanks to a racist system composed of narratives or, to stick with the idiom we established in Chapter 3, a mythic perception of reality. It is mythic to the degree that racism was constructed from what Abdul JanMohamed (1986) calls Manichean allegories. This racism constitutes a barrier to the being of the black body and black people's flourishing in a white racist world. The issue here is difference and the uses 
to which it is put. In the above case, it had been weaponized by white racist societies with the help of legends and myths created to deny the black people recognition on the one hand and to maintain the illusion of superiority on the other.

Besides Vicky Ntetema's undercover report on albinism in Africa, albinism has attracted some scholarly interest, especially in the fields of cultural anthropology, genetics, and disability and human rights studies with leading figures such as Patricia Lund (People with Albinism n.d.), Jennifer Kromberg (2018), and others. On its campaign website against the abuse of people living with albinism, the Human Rights Council of the United Nations states, "Albinism is a rare, non-contagious, genetically inherited condition which occurs worldwide regardless of ethnicity or gender. It most commonly results in the lack of melanin pigment in the hair, skin, and eyes (oculocutaneous albinism), causing vulnerability to sun exposure." (United Nations).

Oculocutaneous albinism is not a disease; it occurs merely due to some form of genetic mutation. In Western societies, people with albinism often go unrecognized, at least not immediately. Indeed, as Charlotte Baker et al. (2010:169) state, "very early Western anthropology assumed that people with albinism were found only in non-European populations, but now it is recognized that albinism is present in all ethnic and racial groups, although prevalence rates vary considerably throughout the world." Ironically, albinism seems to be more prevalent in Africa, and especially in Nigeria, Tanzania, Zimbabwe, and South Africa. In Tanzania alone, albinism occurs at "a rate of more than 14 times that of North America \& Europe" (Under the Same Sun; The Albino Foundation).

Esther S. Hong et al. (2006:212) have declared albinism to be a public health issue. Living with albinism is a challenge; it has health issues such as poor eyesight, involuntary eye movements, skin cancer, and photophobia. Living with albinism in Africa poses several problems, the least of which is dealing with the harsh sun and the practical problems of health care. Living in a continent of people with dark skin color, people with albinism represent easily visible signs of difference. They are therefore treated as the other, exotic. As Giorgio Brocco (2016: 230) observes:

The majority of people with albinism in Tanzania live in marginalized social conditions and a state of economic vulnerability because, apart from having a different physical appearance and suffering from visual impairments, they cannot actively take part in agrarian work due to their sensitivity to the sun, and this effectively excludes them from engaging in the major productive activity in most rural areas.

German cultural anthropologist Brocco lists epithets that allude to the precarious condition of people living with albinism. He states that "In Tanzania, the terms include zeruzeru (ghost), mzungu (white person) and dili 
(which literally means 'deal', and refers to the trade of the body parts of people with albinism on the black market)." Brocco examines the stigmatization of people with albinism as a form of denigration, and this is comparable to epithets hurled at black people in Western countries. He stresses that just as the self-perception of black people is adversely affected by the experience of racism, "the subjectivity and life experiences of people with albinism are strongly shaped by their different physical appearance and attributes" (232).

Anita Franklin et al. (2018:2) argue that albinism is a form of disability not only because of the physical challenges such as photophobia. Indeed, they extend their application of disability to encompass areas in which the condition of albinism disables albinos or renders them incapable of living fully. First, they conceive of disability as an "umbrella term for impairments, activity limitations and participation restrictions, referring to the negative aspects of the interaction between an individual (with a health condition) and that individual's contextual factors (environmental and personal factors)." So disability can be understood socially, psychologically, and physiologically. The social way of understanding disability differentiates between "impairment, the loss or limited functioning experienced by an individual, and disability, the barriers that people with impairments face because of the way societies are structured" (2). This social form refers to the day-to-day effect of living with particular conditions of impairments; this can prevent one from doing something. Another form is when it affects people's psychoemotional well-being. In the former, they experience barriers to doing; in the latter, it is a barrier to being. Barriers to being are imposed by others in society.

Albinism constitutes barriers to doing and to being. Franklin et al. (2018:3) argue that "social processes and practices severely affect children with albinism and as such, they face significant 'barriers to being', most seriously, their right to life and protection and the right to freedom from discrimination." To fully appreciate this form of disability or barriers to being, we recall Fanon's description of the emotional condition of the black man the moment a white child pointed at him and says, "Mama, look, a Negro." Perhaps it helps in this regard to pose a rhetorical question: Is blackness a disability in a white racist country? Indeed, this question has been asked by many African American scholars (Paul-Emile 2018). I approach it not in the conventional context of American identity politics, but rather from a Fanonian phenomenological analysis of the influence of rabid racism on the black body, as shown in the (Fanon) examples above.

The altered subjectivities of those living with albinism is a significant psychological aspect of their lives, and it is thus a major hindrance to being largely owing to low or lack of self-esteem arising from being bullied and epithets being hurled at them. The Human Rights Council of the United Nations states that "The physical appearance of persons with albinism is often the object of erroneous beliefs and myths influenced by superstition, 
which foster their marginalization and social exclusion" (United Nations n.d.). The existence of these myths has direct life-and-death consequences for people living with albinism.

Confirming the effects of the mythic apprehension of reality, Maureen Mswela (Mswela 2017:15) reports that on September 25, 2015, two nineteenyear-old men pleaded guilty in a South African court to the murder of Thandazile Mpunzi, a twenty-year-old woman with albinism. The woman was said to have been deceived by her boyfriend, who had been told by a witch doctor or traditional healer that a charm prepared with the body parts of a person with albinism would make him rich. On that basis, the accused made plans to kill his girlfriend and extracted her body parts for the ritual. Mswela states that

the body parts of persons with albinism are believed to sell for enormous sums of money, and the fact that trading in albino body parts constitutes such a lucrative enterprise and a way to make quick money is an incentive for inhuman acts such as these.

Commenting on the effects of mythology on people's psyches, Charlotte Baker et al. (2010:170) state that "throughout the world, myths function to account for phenomena which are out of the ordinary or which cannot be explained in other terms, fulfilling a fundamental human need to make sense of the world." In their study, they found out that "one of the greatest impediments to a person with albinism taking part in society is that of myths and beliefs that continue to be attached to albinism" (170). Endorsing their explanation, I will later argue that the myths associated with albinism in Africa constitute its greatest impediment to being. First, I examine some of the ways in which mythical explanations of reality shape the reality of people living with albinism. One such explanation is given by a woman with albinism whose mother explained to her the reason for her being born that way thus:

The mother attended a party while pregnant and saw a mother with a baby precariously strapped to her back in a blanket. Fearing the baby was about to fall she went forward to help tighten the blanket. She then saw to her fright that the baby had albinism. She believed that, as a direct result of this encounter, she had given birth to a child affected with the same condition.

Myths are based on often simplistic, abstract, and omni-historical explanations of reality, and they are difficult to disprove for that reason. I also discussed Rene Girard's concept of the scapegoat and the archaic desire in ancient societies to sacrifice one of their own to avert perceived impending 
doom. Usually, the victim is somebody who looks different or one considered dispensable to retain society's moral equilibrium. In ancient Greece, it was always an ugly person, usually from a poor background. The phenomenon of scapegoat, to be sure, is not restricted to ancient societies. Or perhaps it is one of the enduring residues of primitivism found to varying degrees in every society. In times of economic, social, or political crisis, times in which people abandon rational discourse and fall back on myths, strangers and vulnerable members of societies are usually the easy targets of frustration and attack, deemed sacrificeable because of their difference. I argue that the stigmatization of people with albinism is a remnant of the ritual of scapegoating.

The issue therefore is difference and the uses to which it is put. Mary Douglas (1966:4) states that

ideas about separating, purifying, demarcating and punishing transgressions have as their main function to impose a system on an inherently untidy experience. It is only by exaggerating the difference between within and without, above and below, male and female, with and against, that a semblance of order is created.

In the spirit of Fanon's analysis above, we can add the category of black and white to Douglas's binaries. Difference heightens the perception of purity, especially if the thing that differs from the norm is at the same time seen as embodying evil. Indeed, it has to embody all negativity to justify the definer's refusal to identify with it or extend empathy to it. Just as myths help humans to make sense of their lives, they also help to burn prejudices into the psyche and make it extremely difficult to change social behaviors. This, as I indicated above, constitutes the most dangerous condition for people living with albinism in Africa.

On February 19, 2015, the International Business Times ran a seemingly sensational headline titled, "It's Fatal to Be an Albino In Tanzania Due to Cannibalism.” The author, Vittorio Hernandez (2015), writes:

On Feb 14, one-year-old albino boy Yohana Bahati was added to the growing list of Tanzanians abducted and brutally killed due to many Africans still practicing cannibalism and black magic and believe that albinos have power which would be transferred to them if they ate the flesh of one.

It seems sensational for its attention to cannibalism in Africa, indirectly drawing attention to the European modernist framing of Africa as primitive. Pakistani reporter Khurram Shahzad (2016) frames the same issue a bit differently: "Cannibalism or spirituality? Albino children being killed in Malawi for use in ceremonies." A BBC report on the same issue chooses to provide no cultural or religious context; it simply states that up to twenty-five 
people have been killed for their body parts in rituals within a year. In one particular case, a seven-month-old baby "was mutilated on the orders of a witchdoctor peddling the belief that potions made from an albino's legs, hair, hands, and blood can make a person rich" (BBC 2008).

Whether we call it cannibalism or spiritual renewal, the fact is that humans are killed for their body parts, which are used to prepare potions to be consumed. In other words, people consume whatever is prepared with these human body parts. What is cannibalism, if not the practice of consuming the flesh of one's species, whether for food or spiritual benefit? Cannibalism is a crime against humanity, for it goes to the heart of humanity's moral framework and reduces humans to beasts. Cannibalism also goes against the assumptions of human civilization because it undercuts the essential trust and belief in the common good.

\section{Narrating being, narrating difference}

Characters with albinism are rare in African literature, and whenever they appear, they are seen as tropes rather than as individuals in their own right. As Charlotte Baker and Patricia Lund (2017:1) state, its representation "tends to be highly stereotypical, and the qualities of albinism are typically exaggerated to identify characters with albinism as deviant and strange." In Wole Soyinka's The Interpreters (1970), Lazarus the albino is seen as a twilight creature, one that belongs neither here nor there. In Buchi Emecheta's young adult novel, The Moonlight Bride (1983), the bride is albino, and she is very welcome in the village of Odanta; the albino is thus a trope for hospitality. In José Eduardo Agualusa's The Book of Chameleons (2008), the protagonist, Félix Ventura, an albino, sells people their pasts. Nnedi Okorafor's Akata Witch (2011) is a fantasy novel that tells the story of an albino, twelveyear-old Sunny Nwazue, gifted with magical powers. Soon she is part of a group of magic students trying to capture a notorious criminal who also has magical powers. Although the story is about finding one's place in the world, the presentation of the protagonist as a person with magical powers, perhaps because of her difference, makes it more difficult to see her as the regular human being she is supposed to be.

There are equally paltry scholarly works on narratives about albinism. Most works on albinism focus on teaching materials for secondary schools. I feel especially drawn to Charlotte Baker and Patricia Lund's essay for its focus on the possibility of using fiction to teach about human rights in Africa. Following in their footsteps, I discuss three novels: Jenny Robson's Because Pula Means Rain (2000), Tara Sullivan's Golden Boy (2013), and Petina Gappah's The Book of Memory (2015).

Jenny Robson's Because Pula Means Rain is a young adult novel and is one of the few novels devoted to exploring characters with albinism. ${ }^{1}$ It occupies a very important space in the literature of albinism, not only for the subtle ways it exposes the human rights conditions of people with albinism 
but also because it is among the pioneer narratives on the issue. Robson allows us to see people with albinism from inside out, as humans who have the same wishes as others do. Emmanuel's mother abandons him because he is albino, and he lives in Kedia Heights, Botswana, with his grandmother, who is to him the opposite of what his mother had been. The novel is about his journey to self-discovery. My interest in the novel rests primarily in the psychological struggle that the character goes through as his encounters with others remind him of his difference to the rest of his world, and I compare that with the already mentioned condition of the Negro in Fanon's Black Skin, White Masks. I shall, therefore, restrict my analysis to what Emmanuel considers as barriers to his being.

What strikes the reader from the first page is that Emmanuel identifies himself as an alien being. He is alien in a double sense; his mother had abandoned him, and he now lives with his grandmother in a different village. So, he is alien to that village. The people have stories about his origin. His mother had "been with a white man. A bad white man. That is why Gladys Lesenyamotse has birthed this deformed child" (Robson 2000:22). Emmanuel states that the stories were too hard for his mother to bear, and so she left him with his grandmother.

But Emmanuel is also alien to the village people in the sense of his color, and this is the ultimate source of his psychological pain. As the black man in Fanon's analysis, Emmanuel is painfully conscious of his difference, and this weighs on him like a heavy burden and a hindrance to being. When a friend, Sindiso, offers to take him to Gaborone, the capital city, he is excited and cannot hide his joy. He remarks that it is a "city full of thousands and thousands of people who would be too busy to take any notice of me!" (3). If the smallness of the village setting had constituted a hindrance to his being, he hopes that the anonymity and perhaps the cosmopolitanism that cities usually offer will lift that hindrance. Like the black man in Fanon's postcolonial analysis, Emmanuel reads everything through the prism of his difference. When his grandmother urges him to dress well for the city, he reads much into her otherwise innocent admonition. He observes rather sharply: "She pretends that if I dress smartly, everything will look fine. If my shirt is clean and mended, then people won't notice the strangeness of the face above the collar" (6). He suffers anxiety from being constantly under the gaze of others, and with this comes self-deprecation, a major hindrance to human flourishing.

Jean-Paul Sartre writes in his preface to Fanon's Wretched of the Earth that "the status of 'native' is a nervous condition introduced and maintained by the settler among colonized people with their consent. Laying claim to and denying the human condition at the same time: the contradiction is explosive" (Fanon 1967:17). The situation of the native or the colonized is that they are denied their humanity, even though the colonizers accepted, however grudgingly, that they are humans; this condition subjects the colonized to a permanent state of anger and in most cases also doubts about his 
humanity. He demands justice in the form of recognition. Emmanuel also experiences a nervous condition because he does not feel that others have respect for his person. Just as the native is blamed for his skin color and is therefore responsible for the rejection of his being, Emmanuel thinks of self-mutilation. He says: "I longed to pick up a shard of glass and stab it into my flesh because my flesh was wrong" (Robson 2000:8). But this self-hatred is a reflection of how society reacts to his difference, especially with anecdotes about how his mother conceived him. Expressed in Fanon's language, society has woven Emmanuel out of thousands of anecdotes that are devoid of dignity. That is why he hates mirrors; he hates to see his reflection. He has introjected others" perceptions of him and calls his skin "pig-pink skin" (10).

Emmanuel tells of a particular incident in which he experienced the Negro moment:

A young girl was tugging at her mother's skirt just beside the petrol station. "Mama, look! It's a pink man! Why is he pink, Mama? He looks funny. Is he a ghost?" The mother slapped the girl's pointing finger. I heard her answer above the chatting of so many waiting passengers. 'Don't you look at him, you hear me! And don't you laugh at him. Otherwise when you are big you will have a baby just like that! Do you want to have a baby just like him?'

The more painful part of the experience is not that the child points at Emmanuel; it is the mother's reaction that further turns Emmanuel into an abhorrent object. This supports Emmanuel's earlier dubiousness about his society. "What is the point of turning away from reflecting windows when my ugliness and my abnormality show in the eyes of everyone who turns my way?" (16). This observation seems to have an accusatory tone, perhaps designed to be not downright accusatory, but rather Robson's gentle way of reminding society of its encroachment on the dignity and moral space of this particular vulnerable member.

Emmanuel realizes that he is not safe, even in the city. He enters a bookstore and tries to communicate with a white boy. He might feel some instinctive identification with the white boy, believing that his own skin color will not scare the boy. He's disappointed that even the boy finds him strange. Emmanuel says: "I saw his eyes grow wide. And then he screamed: 'Mo-am! Mommy! It's the boogie-man! He's trying to get me! The boogie man, Mommy!"” (38). Here, again, is a Fanon-moment, a threat to Emmanuel's existence as a human who, in Fanon's words, "came into this world anxious to uncover the meaning of things, [his] soul desirous to be at the origin of the world" (Fanon 2008:89). But the world around him will not allow Emmanuel to be; it objectifies him. Yet Emmanuel wants to belong; he is determined to be part of the community he was born into. He reflects: "Why couldn't I just be a person like everyone else?" (Robson 2000:75). In this moment 
of self-doubt, we are drawn closer to his humanity; the self-doubt reveals his vulnerability and asks: Am I not a human being? He demands justice by challenging the reader to respond to it and to consider why his society subjects him to gratuitous pain. If this is the case, then it is incumbent on society to stop it. This is the human rights challenge of the novel. Emmanuel narrates human rights. We feel his wish that others put themselves in his position and realize that his wishes are like those of other humans.

Emmanuel wants to be recognized as a regular human being, and, for that, he undertakes a perilous journey into places that many people from that cultural background would go if they have his or similar problems. He goes to magical and spiritual healers to have his skin restored to that of humans; he went to Mama Jay from South Africa who practices witchcraft; to Brother John, a Christian miraculous healer; and to Ngaka, a herbalist (84-114). After going through the magical healing processes, he realizes that his physical condition cannot be changed. "Forever and forever I would stay an albino. The freak of the village" (115). His self-flagellation makes us cringe, but at the same time realize that we, the society, are responsible for that. Society pushes Emmanuel to hate himself.

Robson achieves an important feat in providing Emmanuel with agency. In Emmanuel, we do not see somebody who complains and succumbs to his fate; rather, we see a human being doing everything possible to overcome his fate and to remind his society of the justice he deserves. He realizes that the first thing to do is to accept himself, and he does so by understanding his past. He learns that his ancestor was an albino who had been accused of betrayal by his people. Unable to deal with the village's rejection of him, the ancestor had walked away and had never been heard of again, "still searching for a place he could call home" (118). Emmanuel does not want to end that way. Unlike his ancestor, he decides to stay in the village. "My village. Yes, my village. Home of my people" (133).

Two things are at stake here, both of which are integral parts of Emmanuel's identity: history and the body. Emmanuel cannot change either of them. He must accept them, and he wants to make his society do the same. Charlotte Baker and Patricia Lund (2017) identified that this young adult novel is excellent for educating people about albinism and human rights. For one, Emmanuel's acceptance of his condition urges readers who do not yet know about albinism to follow in his footsteps. Above all, though, the narrative shows Emmanuel as a human with subjectivity. This, I think, is the enormous advantage of the novel's first-person point of view. He tells, and readers listen; in so doing, he invites people into his interior life. He is not a beast. If society's gaze has turned Emmanuel into a beast, attention to his interiority achieves the opposite; it seems to remind society of his subjectivity as a being deserving of moral attention. Alone in this, Robson might have approached one of the goals of her didactic narrative: sensitize her young readers to the pain of others, and challenge older adults to become aware of the moral obligation to protect the human rights of others. 
Tara Sullivan's Golden Boy is also a young adult novel. It is set in Tanzania and tells the story of Habo, a boy living with albinism. His condition does not sit well with the members of his family, who are obviously of a different skin hue. His father abandons the family because of him, and his mother does not give him much-needed attention and love. Only his sister, Asu, loves him the way he is. The family is forced to leave their village because of his difference. They find refuge in Mwanza, a town close to Lake Victoria. But even there, he does not find acceptance; indeed, his life is in even greater danger, for people with albinism are hunted for their body parts in that region of the country. He must find a way to survive. Like in Jenny Robson's Because Pula Means Rain, my discussion of Golden Boy centers in particular on the structure of Habo's encounter with people, how others perceive him, how he perceives himself, and what all this says about human rights and dignity in that space.

These two young adult novels have many things in common in addition to their obvious narrative about albinism. Habo's and Emmanuel's mothers are both abandoned by their husbands. This is in line with the folk belief that the mothers of children with albinism are to blame because they might have done something wrong. As Charlotte Baker et al. (2010:172) state, "Because of the stigma associated with the condition, many children with albinism are brought up by single mothers because the father often leaves when the woman gives birth to such a child." Whereas Emmanuel's mother drops him off in her own mother's house to live with her, Habo's mother does not get rid of him, but she does not shower him with love either. Indeed, Habo's mother becomes a source of torment when she reminds him not only of his uselessness but also of the fact that he is a stigma to the whole family (Sullivan 2013:13). Perhaps her failure to fully accept Habo indirectly encourages Habo's two brothers to consider him as not fully human; they think of him as a ghost, suggesting his insubstantiality in their eyes (4). Habo tells his story in a sympathy-evoking voice: "I distinctly heard Chiu's voice whispering 'mtoto-pepo-ghost boy'. Burning with shame, I stood there alone and listened as the plague of whispers ate my hopes" (39). The reader's attention is arrested by Habo's reference to hope. We assume it is his hope to be accepted as fully human. The story the author touches on is that of what all humans have in common: the desire and hope to be treated fairly. Habo's worthlessness in his people's eyes is not restricted to their verbal abuse; they physically abuse him as well (4).

As I have already discussed above, Brocco has observed that people living with albinism are humiliated with epithets such as zeruzeru (ghost) or mzungu (white person) and that these names affect their self-esteem. Habo understands that zeruzeru means "zero-zero," or "nothing." He tells that "A zeruzeru is an unnatural thing, like a zombie. It's like calling me an animal" (Sullivan 35). Of course, such labels make a great impact on Habo's self-esteem and behavior. Born a stranger, he feels less worthy as a human. His pain expresses itself in tears. "With each sob I feel the tearing pain of 
not fitting into my own village, my own family, since the day I was born" (232). Faced with a world that despises him, Habo makes a devastating judgment about himself-“I'm hardly a person" (9). Habo's experience underlines what Fanon means when he says that "the image of one's body is solely negating. It's an image in the third person" (Fanon 2008: 90). Thus, the Negro-moment turns out to be an albino-moment, a moment of selfperception as a person without dignity.

In her already cited article, Maureen Mswela (2017:116) states that "the body parts of persons with albinism are believed to sell for enormous sums of money," and that is an incentive to hunt for people with albinism. Having been made aware that he is not as worthy as others with brown skin, Habo also hears that "He's really an animal" (Sullivan 2013:21). In a heartrending cry for help, he comments that people "are throwing rocks on me for fun, like I'm a street dog" (23). He is stunned to hear his own brother, Chui, make a reference to his being an animal that can be killed for its worth in money: "I am okay with killing one animal. To not be poor" (55). Habo is devastated to hear this from his own brother, and this is an instance of microcosmic infringement on human rights. Right there in the verbal exchange between Habo and Chui, we see the core registers of human rights violated. In an uncanny foreshadowing of the rest of Habo's problems, on the family's way to Mwanza they meet Alasiri, a rich man who makes money from poaching ivory. Alasiri kills elephants but "leaves the meat alone. He harvests the teeth and tails and toenails" (45).

Sullivan's careful paralleling of Habo and the elephant enhances our understanding of Habo's precarious condition; he is despised as a human being but appreciated for his utilitarian value as an animal. In an ominous foreshadowing of his likely fate, he notices Alasiri's "delight over the kill" and feels with the poor animal (45). His co-feeling with the poached animals excites ours too and prepares us to understand his agony, especially when he learns that Alasiri and other poachers are looking for albino body parts. In the Mwanza-Lake Victoria region, people believe that albinos bring good luck. He is devastated to hear:

Your hands and hair alone are worth more than a year's salary. Your skin is enough to buy a car, your legs are worth a great deal more than all the rest of you put together. Because it's your legs, Habo, Habo that will win Msebo this next election.

The body parts of people living with albinism are sold to the witch doctors, who prepare good luck charms to be consumed by their clients. "Bones are ground down and buried in the earth by miners, who believe they will be transformed into diamonds. The genitals are made into treatments to bolster sexual potency" (Malone 2009). The melding of primitive belief systems and brazen cannibalism would have struck the reader as Sullivan's 
ill-placed narrative technique to mock the abuse of the human rights of people living with albinism if Vicky Ntetema had not already exposed the practice as widespread in Tanzania and the surrounding countries. The above rituals are in line with a belief and cultural system steeped in mythic consciousness.

Although we already see Habo's subjectivity in his feelings of shame and disappointment at how his brothers and other children treat him, Sullivan gradually brings us closer to Habo's pained interiority when he learns that he is now in a region in which nearly everyone believes albinos are subhuman. He hears about the killing of people with albinism because their body parts are used in potions sold by witch doctors (Sullivan 2013:67). We feel his vulnerability most when he says that he wants to disappear:

I put my cup of tea on the floor, no longer able to drink it. I hug my knees to my chest and put my head down onto them so I don't have to see anyone looking at me anymore.

His world no longer provides an environment suitable for his flourishing as a human being. It is therefore not surprising that he decides to run for his life. He leaves for Dar es Salaam, the capital city of Tanzania, where he hopes to escape the bigotry and the grip of primitive traditions and beliefs.

Like Emmanuel, Habo is lucky to have a few people who keep in his life the sure knowledge that he is as fully human as they are. Not all people are shocked by his difference at birth. His sister, Asu, lets him know that when he was born, while others were shocked by his whiteness, she reached out to him: "I picked you up" (29). The reader feels his pride in his narration of how Asu has kept reaching out to him: "Asu scoops me up into a hug and kisses my head before setting me in her lap" (70). To touch is to affirm, to recognize the other body as present and, phenomenologically speaking, as an extended part of oneself. It is therefore a gesture of justice. Touch is one of the most fundamental forms of recognition.

Jean-Luc Nancy (2018) argues that the body is only the viewpoint from which this perceiving, which is also an action, can be organized. Like all points, the viewpoint is without dimensions. In Asu, Sullivan urges the reader to see albinos as humans who desire touch as much as the rest of us. Habo is lucky to land in the house of Kweli, a blind sculptor who hires him as his apprentice. True to his condition as a blind person, Kweli does not judge him based on his skin color; he is able to see Habo or, rather, not see his exteriority or epidermal difference; he perceives Habo by touching him. It is instructive concerning the importance of the body as a theatre of existence that Kweli engages with the world through his sense of touch. So when he comes in contact with Habo, he is able to come in contact with what others (except his sister) are not able to do. He accepts Habo (Sullivan 2013:163). He listens to Habo and sees with the eyes of the heart. 
There is a subtle allusion to Antoine de Saint-Exupéry’s (1971:73) The Little Prince, who famously declares that "only with the heart that one can see rightly; What is essential is invisible to the eye." In Kweli, Habo feels recognized for who he is: "Today, I was normal." And he says of Kweli: "He treats me like a normal person" (Sullivan 2013:205). As if to enhance the Exupérian notion of deeper meaning, Kweli invites Habo into his philosophy of carving and life. "A sculptor," says Kweli, "does not carve a thing, but a meaning" (218). Kweli suggests that meaning in life does not lie elsewhere but in the life of the person when he tells Habo that "The way we give shape to an idea, boy, is to show its shape in our life" (219). Habo confirms Kweli's wisdom when he says to himself: "Yes, I will fit there. Yes, I could carve here. Yes, I can do this" (221). His discovery of the true meaning of life with Kweli contrasts with his former sense of self among his own people, especially his brothers - those who never really touched him. Kweli brings to full circle the recognition Habo's sister had begun. Habo begins to touch things and feel the world because he has been touched; his body has been affirmed.

\section{I tell this story to demand justice}

In an interview granted to NPR's Renee Montagne, Petina Gappah stated that in writing The Book of Memory, she wanted to say something about race without being racialist. "In Zimbabwe somebody [with albinism] looks white but doesn't have the privilege that whiteness brings with it. And at the same time, that person is supposed to be black but doesn't actually look black" (NPR 2016). But does how one say something about race without being racialist? This can be done by inventing an allegory or by turning the conventional understanding of race and racism on its head so that those who had been at the receiving end of racism become the ones to hold the power to name or frame reality. The Book of Memory achieves precisely that. It tells the story of Memory, an albino girl in Zimbabwe. Neither black nor white, she is the object of ridiculing gazes because of the color of her skin in a land of black people. Ironically, she is adopted by Lloyd, a white man, who sees his fate as a white man in Zimbabwe reflected in Memory's condition. Members of a nationalist band kill Lloyd and frame Memory as the culprit. She is condemned to jail, where she tells her story. It is obvious that the reference to memory is against the backdrop of Zimbabwe's history of colonialism better articulated by Gappah's famous compatriot, Tsitsi Dangarembga in Nervous Condition. In contrast to Lloyd, a stand-in for the British presence in Zimbabwe, Memory has only a vague, inchoate recollection of her past; indeed, her past is not recorded. In her review, Becca Rothfeld (2016) states that the story "is an attempt to reclaim, by way of reconstruction, a genealogy both personal and cultural, an exercise in self-searching that upends many of Memory's most deeply entrenched conceptions about herself and her origins." Color plays an important role in the lives of the people, and this is no doubt traceable to the horrors of their past as colonized people. 
Zimbabwe's history goes beyond color or race relations. There are also many ugly chapters in its history that beg to be remembered: Robert Mugabe's genocide in Matabeleland and which goes by the name Gukurahundi. Yvonne Vera's The Stone Virgins also documents another aspect of Zimbabwe's history that ought not to escape the collective memory: the horrors of the Independence war. Anita Sethi (2015) states that "Gappah grapples with the grand themes of fate and free will, love and loss, the collision of tradition and modernity, the impact of politics on the personal." In a blog post, Shingi Mavima (2018) made an incisive observation about the novel. Gappah, he argues, humanizes "historically marginalized characters." I endorse Mavima's take on the novel, and rather than read it through the obvious postcolonial lense of race, I engage the fate of marginalized characters, especially Memory.

Like Emmanuel in Because Pula Means Rain, Memory feels objectified by her society. Indeed, she begins her story by announcing the condition that makes her a stranger and an object of ridicule in her society. She is "murungu$d u n h u, \ldots$ a black woman who is imbued not with the whiteness of murungu, of privilege, but of $d u n h u$, or ridicule and fakery, a ghastly whiteness" (Gappah 2015:2). She is "black but not black, white but not white" (7). She is in a dangerously liminal space or in the twilight of being. For a world that is still governed by the Manichean binary vision of truth, not being either white or black is a curse. Her being is on the fringe. In her understanding, her body is not deserving of admiration because it is an object of pity. She sees her ugliness reflected in another albino, "Lameck, who had a squashed face and red, blotchy skin that broke over his arms and face" (54). It is interesting that in comparison to Emmanuel, who sees his ugliness reflected back at him in the mirror and in other people's gazing at him, Memory arrives at the ugliness of her own condition by looking at other albinos. Every time she passes Lameck, she sees "the flies that settled on his mouth" (55). She is afraid of Lameck and so does not wonder that people are afraid of her. This condition makes her arrive at a devastating self-judgment: "I see now, of course, that he was just as much a misfit as I was" (55). The fact that Memory identifies another person who occupies the same position as she does underscores the precarious condition of such people as the new wretched of the earth, those who are considered expendable. Memory and Emmanuel's stories are rich for the very reason that they expose the inner world of the characters; they let us know how they feel and their dreams and aspirations. We are aware of how precarious they perceive their lives to be, and this is a preliminary and, indeed, essential step in their quest for recognition of justice.

Not much happens in Memory's narrative, but every incident is loaded with meaning. Her painful honesty about herself might appear somewhat self-deprecatory, but it achieves the first goal of narratives in the realist tradition, which is to bring the human condition to the fore, to foreground life as it is. The truth is that albinos have experiences such as those described by Memory, and when she becomes honest about herself, it is to draw her 
listener's attention to the condition of her body as a fellow human occupying the same space, a body that desires a basic human touch. It is, at the same time, a body that has been objectified by society's oppressive gaze.

Gappah, not interested in spectacle, keeps the narrative focused on the ordinary life of Memory. She is interested in our ethical response to difference, understood not only in racial terms. Memory's difference from the norm raises a profound ethical challenge to her society. The question is: how do people relate to her? Even though Memory speaks of her condition in deprecatory terms, there is a substantial difference between her emotional attitude to her world and that of Emmanuel. Whereas Emmanuel appears to be eager to attract pity, which casts him as a victim, Memory is not ready to succumb to her condition; she is not prepared to be a victim. To be sure, both of them seek some connection to their audience, but their approaches are qualitatively different. The Book of Memory is a first-rate literary fiction that deploys many registers of literality such as intertextuality, an allusion to the classics, irony, and others to achieve its sophistication. Memory wants to be seen as an individual who is not lost in abstraction.

Hannah Arendt (1958:9-27) differentiates between human condition and human nature. The human condition surrounds the lives of individuals as part of a community, while human nature seeks to capture the general, abstract thing that is thought to be common among individuals; it seeks to establish the norm. Those who aim to define human nature seek to establish the essence or an absolute condition of things and often resort to ideology, which notoriously seeks to explain humans in broad strokes. Ideologies function under the premise of human nature. Racism, sexism, tribalism, and bigotry are all results of obsession with human nature. We relate to our fellow humans based on the parameters given by the fact of our natality, not by human nature. Seeing individuals through the prism of human nature denies them their individuality and makes them invisible. This is largely because the belief in human nature posits only a certain type of human, usually without blemishes, but the reality is usually different. The human condition foresees the fact of vulnerability; it acknowledges difference without weaponizing it.

Memory regrets that other people's perception of her is conditioned by abstraction - that is, by their notion of human nature. People do not see her as an embodied being; they hardly imagine the pain she experiences. Her mother sees Memory's condition as a curse that can be taken care of only with the help of the spirit world. She allows her relationship to her daughter and to the world to be dictated by diviners and prophets. As Memory explains, "My mother believed in the spirits and the mediums through which they spoke. She believed in healers and diviners" (Gappah 2015:118). From Memory's perspective, religion stands in the way of her mother taking her (Memory's) body seriously. Indeed, religion conditions her mother to send Memory to a foster home, a gesture that Memory interprets as being sold. Memory, therefore, observes that religion does not contribute to people's 
self-esteem; the opposite is more often the case. She tells of a church service she attended in which the preacher unleashed words that debased rather than uplifted the faithful (116). Religion works predominantly from the perspective of human nature; it views individuals as predetermined by their essences, dictated by a divine being so that what is needed is for society to relate to humans accordingly. Memory narrates to liberate herself from the totalizing grip of abstraction; she narrates to draw attention to her body and its difference and so alert people to the injustice their attitude to her inflicts on her. She wants people to have a second look at her, and this second look will be achieved the moment the reader begins to listen to her story. In effect, Memory initiates a dialogue with the reader like that between two lone strangers in a bus station, waiting for a bus that will not arrive. It is her quest to be treated fairly, be accepted like a regular human being.

In The Book of Memory, narration becomes not only a means of understanding the self and initiating a relation to others; it also becomes a lifesaving act. We recall that she is condemned for supposedly killing Lloyd. She is therefore at the risk of losing her life, and that would constitute a miscarriage of justice. She, therefore, hopes that telling her story would bring her justice. Memory narrates:

It was Vernah's idea that I should tell my story to you. Before she sent you to interview me, she told me that I should write down every detail that I could remember, that I should record everything that could make a sympathetic case.

The judge stands in for the prospective reader, who is asked to understand Memory's condition. It is hoped that if the court hears the details of Memory's story, it will consider her case more favorably. Memory is fully aware of the lifesaving potential of story. Memory believes that what saved Scheherazade, the Persian bride, might also save her. But what does it mean to be saved by stories? To narrate is to appeal. It is to plead to be taken into a certain hermeneutic community. It is an ethical gesture. The narrator wants to be recognized as one capable of existing within that ethical or hermeneutic community. She is therefore a modern Scheherazade, who must tell a story in order to live (87). The reader knows that Memory is not guilty of the crime for which she sits in jail; she has been framed by members of a nationalist gang. Here then, she narrates to make listeners see reality from her perspective and to see her as a person deserving of co-feeling. Listeners must put themselves in her position to reach some level of relation. Memory fights for justice on two fronts: in the legal sense, on the court of law, and in the moral sense, for acceptance by society as a regular human being.

To fully understand the context of Memory's ultimate desire, we recall the South African expression, Umuntu ngumuntu ngabantu - a person is a person through other persons - made popular by Desmond Tutu. I highlighted 
specifically the South African philosopher Thaddeus Metz's argument that ubuntu is about the development of an individual's moral personhood, which begins from the moment an individual becomes aware of the degree to which he or she contributes to the affirmation of the other, because, according to the saying Umuntu ngumuntu ngabantu, this other cannot be who he or she is without oneself. In this way, community is not an abstract thing; instead, it is concretely realized in the relationship between two persons, a relationship exemplified by that between the storyteller and the listener, between text and reader-that which Memory seeks in her Scheherazade moment. Scheherazade seeks to humanize the king with stories and thereby negotiates for her life with stories; she wants the king to recognize her as human.

Gappah set out to turn the racist world on its head. She seems to have achieved more than that. She created a character that narrates a story in order to turn her oppressive world on its head. Her ultimate goal is to experience justice, which is purely about the right to live.

\section{The Albino and recognition}

In Chapter 7 of Black Skin, White Masks, entitled "The Black Man and Recognition," Fanon enhances the understanding of the lived experience of the black man. At the core of the Hegelian master/slave dialectic is that the slave recognizes the master, whereas the master refuses to extend the same recognition to the slave. This condition is what defines their status. Were the master to extend recognition to the slave, the slave would no longer be what he is. Fanon agrees with Hegel that humans are what they are because they are recognized by others. He states that a person's "human worth and reality depend on this other and on his recognition by the other. It is in this other that the meaning of his life is condensed" (Fanon 2008:191). Hegel states that the condition of the master and slave is more or less fixed, so that the slave does not need to question his status arising out of a primordial battle. Fanon disagrees. It is clearly in the nature of humans to be recognized; "each consciousness of self is seeking absoluteness. It wants to be recognized as an essential value outside of life, as transformation of subjective certainty ( $\mathrm{Ge}$ wissheit) into objective truth (Wahrheit)" (192). The slave can therefore not be satisfied with the condition that denies him or her the absoluteness; he or she desires completion. He or she asks that he or she "be taken into consideration on the basis of [his or her] desire" (193). This desire is what makes us human. What Fanon says about the Negro's desire for completion in the white world applies without qualification to the albino in Africa. I consider recognition to be a condition for the flourishing of human rights.

Recognition is the immediate result of our attention to the practice of the ordinary. We discover one another as conditioned by our common humanity. Community is where recognition is conferred; that is, in action and speech, we recognize one another as human beings without whom our 
existence would not be possible. This desire for recognition is most poignantly expressed by Memory, who states, "I longed to be like all the others. I tried to get as dark as the other children. I longed to belong" (Gappah 2015:57). She is invisible in a society that acknowledges only dark-skinned people. She prays for dark skin; otherwise, she would remain invisible. In Memory, therefore, Gappah pleads for the justice for albinos, who are the most visible markers of difference and otherness in a country of darkskinned people.

\section{Note}

1 Jenny Robson was born and raised in South Africa. She now lives in Botswana, where she teaches music.

\section{References}

Arendt, Hannah. 1958. The Human Condition. Chicago, IL: The University of Chicago Press.

Baker, Charlotte and Patricia Lund. 2017. "The Role of African Fiction in Educating about Albinism and Human Rights Jenny Robson's Because Pula Means Rain and Ben Hanson's Takadini." Journal of Literary \& Cultural Disability Studies 11 (3): $1-13$.

Baker, Charlotte, Patricia Lund, Richard Nyathi, and Julie Taylor. 2010. "The Myths Surrounding People with Albinism in South Africa and Zimbabwe." Journal of African Cultural Studies 22 (2): 169-181.

BBC. 2008. "Living in Fear: Tanzania's Albinos." http://news.bbc.co.uk/2/hi/ africa/7518049.stm (Accessed April 11, 2018).

Brocco, Giorgio. 2016. "Albinism, Stigma, Subjectivity ad Global-Local Discourses in Tanzania." Anthropology \& Medicine 23 (3): 229-243.

De Saint-Exupéry, Antoine. 1971. The Little Prince. Translated by Katherine Woods. New York: Harcourt Brace Jovanovich.

Douglas, Mary. 1966. Purity and Danger: An Analysis of Concepts of Pollution and Taboo. London: Routledge.

Du Bois, W. E. B. 1996. The Souls of Black Folk. New York: The Modern Library.

Fanon, Frantz. 1967. Wretched of the Earth. Harmondsworth: Penguin Books.

Fanon, Frantz. 2008. Black Skin, White Masks. Translated from the French by Richard Philcox. New York: Grove Press.

Franklin, Anita, Patricia Lund, Caroline Bradbury-Jones and Julie Taylor. 2018. "Children with Albinism in African Regions: Their Rights to 'Being' and 'Doing," BMC International Health and Human Rights 18 (2). https://pubmed.ncbi. nlm.nih.gov/29329540/ (Accessed April 13, 2019).

Gappah, Petina. 2015. The Book of Memory. New York: Farrah, Straus and Giroux.

Hegel, Wilhelm Gottfried. 1971. Philosophy of Mind: Being Part Three of the Encyclopedia of the Philosophical Sciences (1830), edited by William Wallace. Oxford: Clarendon Press.

Hernandez, Vittorio. 2015. "It's Fatal To Be an Albino in Tanzania due to Cannibalism." International Business Times. http://www.ibtimes.com.au/its-fatal-bealbino-tanzania-due-cannibalism-1423185 (Accessed April 11, 2018). 
Hong, Esther S., Hajo Zeeb, and Michael H. Repacholi. 2006. "Albinism in Africa as a Public Health Issue." BioMedCentral Public Health 6: 212. https://www.ncbi. nlm.nih.gov/pmc/articles/PMC1584235/ (Accessed January 8, 2019).

JanMohamed, Abdul. 1986. "The Economy of Manichean Allegory: The Function of Racial Difference in Colonialist Literature," pp. 59-87 in "Race," Writing, and Difference, edited by Henry Louis Gates, Jr.. Chicago, IL: University of Chicago Press.

Kromberg, Jennifer and Prashiel Manga. 2018. Albinism in Africa Historical, Geographic, Medical, Genetic, and Psychosocial Aspects. London: Academic Press.

Malone, Andrew. 2009. "The Albino Tribe Butchered to Feed a Gruesome Trade in 'Magical' Body Parts." http://www.dailymail.co.uk/news/article-1215949/ The-albino-tribe-butchered-feed-gruesome-trade-magical-body-parts.html (Accessed April 10, 2018).

Mavima, Shingi. 2018. "Petina Gappah's "The Book of Memory"-A Quick Review." https://medium.com/@shingimavima/petina-gappahs-the-book-ofmemory-a-quick-review-af56133aa200.

Mswela, Maureen. 2017. "Violent Attacks against Persons with Albinism in South Africa: A Human Rights Perspective." African Human Rights Law Journal 17 (1): $114-133$.

Nancy, Jean-Luc. 2018. "Body Theatre," in Mika Elo \& Miika Luoto, Figures of Touch Sense, Technics, Body. The Academy of Fine Arts at the University of the Arts Helsinki. Visual concept BOND Creative Agency Helsinki, Tallinna Raamatutrükikoja OÜ.

NPR. 2016. "Sentenced To Death For Murder, A Woman Tells Her Story From 'Memory'." Author Interviews. https://www.npr.org/2016/03/01/467259286/sentencedto-death-for-murder-a-woman-tells-her-story-from-memory.

Okorafor, Nnedi. 2011. Akata Witch. New York: Viking Books.

Paul-Emile, Kimani. 2018. "Blackness as Disability?" Georgetown Law Journal 106 (293). https://ir.lawnet.fordham.edu/faculty_scholarship/886/ (Accessed January 8, 2019).

People With Albinism. No date. "Patricia Lund." http://albinism.ohchr.org/storypatricia-lund.html (Accessed April 10, 2018).

Robson, Jenny. 2000. Because Pula Means Rain. Cape Town: Tafelberg.

Rothfeld, Becca. 2016. “The Book of Memory', by Petina Gappah.” New York Times. https://www.nytimes.com/2016/02/28/books/review/the-book-of-memoryby-petina-gappah.html.

Sethi, Anita. 2015. The Book of Memory Review-A Vivid Life Story from Death Row." The Guardian. https://www.theguardian.com/books/2015/aug/16/ the-book-of-memory-review-petina-gappah.

Shahzad, Khurram. 2016. Daily Pakistan-Global. https://en.dailypakistan.com. $\mathrm{pk} /$ world/cannibalism-or-spirituality-albino-children-being-killed-in-malawifor-use-in-ceremonies/ (Accessed April 11, 2018).

Sullivan, Tara. 2013. Golden Boy. New York: G.P. Putnam's Sons.

Under the Same Sun. No date. https://www.underthesamesun.com/sites/default/ files/Frequency $\% 20$ of $\% 20$ Albinism.pdf.

United Nations. No date. "Independent Expert on the Enjoyment of Human Rights by Persons with Albinism." United Nations Human Rights Office of the High Commissioner. http://www.ohchr.org/EN/Issues/Albinism/Pages/IEAlbinism.aspx. 


\section{$5 \quad$ Intimate justice \\ Homophobia and human dignity}

African postcolonial discourse, which had been largely about African resistance to Western epistemic shaping of Africa, had been devoted to the civil spaces in African thought at the expense of intimate spaces, especially of women and people of alternative sexualities. African thinkers and freedom fighters, who had been predominantly male and heterosexual, had privileged discourse about subjugated black population as a whole, and, in most cases, it all centered not only on the violence perpetrated on the male body but also on the wishes of that body. The wishes and desires of the African female body are often considered secondary or at worse subsumed within the imaginary of what was thought to bring about the good of the oppressed community. Thus, whereas postcolonial resistance had been about social justice, the area of intimate justice was summarily ignored.

According to Sara McClelland (2014:1010), intimate justice "is a theoretical framework that links experiences of inequity in the sociopolitical domain with how individuals imagine and evaluate the quality of their sexual and relational experiences." Studies about intimate justice, she explains, center on how 'individuals' evaluations of their lives - and specifically their levels of satisfaction, well-being, and happiness - should be assessed using measures and methods that always consider both potential group differences and the social conditions that may influence these appraisals" (1010). The premise of intimate justice is that the dignity we accord humans in social settings is no different from that which we accord them in intimate spheres. If we admit that every individual has dignity, then we must extend the implication of this fact to their right to moral sphere.

Intimate injustice comes about because of society's compulsion to regulate and control people. In The History of Sexuality, Michel Foucault explains that the body is the means through which society displays its power and control. This is done through the control of pleasure, especially in sex: when, how, and with whom it is exercised. Strictly speaking, therefore, to control sexual practice and relations is to control society. Foucault (1978:155) states that:

The notion of sex brought about a fundamental reversal; it made it possible to invert the representation of the relationships of power to 
sexuality, causing the latter to appear, not in its essential and positive relation to power, but as being rooted in a specific and irreducible urgency which power tries as best it can to dominate.

Furthering Foucault's thoughts, Judith Butler (1995) examines how the power of heteronormativity frames the relevance of bodies, sex, and gender. She argues that power operates by defining what counts as legitimate sex and in so doing it contains and constrains sex. Butler characterizes this regulation and the resultant categorization as "a violent one, a forceful one." For her, "the discursive ordering and production of bodies in accord with the category of sex is itself a material violence" (Butler 1995:52). Body normativity refers to the standardization of certain types of bodies in the social and cultural domain (Yep 2017:117). The first goal of normative structures is to impute values to things; it is to categorize and, in so doing, decide which is to be accepted or rejected, which is superior or inferior. The issue therefore is about power, and wherever it manifests itself, justice is denied. Normativization ultimately leads to injustice because it considers some bodies as surplus. A body is surplus if it is not an essential part of a given normative structure or if it is conceived of as means to an end rather than an end in itself, when it is not part of the norm. In most African cultures, women and people with alternative sexualities do not belong to the normative group. Within heteronormative patriarchy, women are constructed as a means to an end, while homosexuals are seen as deviant bodies. Within such normative contexts, these bodies are deemed to possess no dignity, at least, not as much as heterosexual male bodies do.

Religion, public morality, and politics are some of the means through which these normative paradigms are maintained. What is considered worthy of dignity is only what complies with the generally accepted order, and what is an accepted order is usually defined by those who have the power to do so. By definition, surplus things have little or no value in themselves, and losing them makes no difference in the scheme of things. In this chapter as in the next, I consider manifestations of intimate injustice in African discourse. I discuss these bodies that fall outside accepted norms in Africa, starting with the bodies of members of the LGBTQ community and the human rights implications of their precarious condition in society. First, I establish in this chapter the environment that enables the abuse of the rights of the LGBTQ community and then I analyze three forms of narratives: documentary film, poetry, and prose fiction.

\section{Religion, politics, and heteronormative violence}

In the late decade of the twentieth century, the world breathed a sigh of relief at the end of the Cold War and the official demise of apartheid. But then there emerged a new kind of war, or more precisely, a battle for the soul of the world. In Africa, it was the battle for spiritual transformation, championed 
largely by the Evangelicals in America. Africa had to be liberated from the stranglehold of the Devil. No other place is this battle more manifested as in the area of sexuality. According to Kapya Kaoma (2009a), the U.S. political Right, which had staunchly supported apartheid and was consequently a pariah in Africa, has now taken a center stage in the new fight for the African soul. It has successfully conscripted Evangelicalism as the well-known path of seeking to control the body by capturing the mind. Evangelicalism is now an integral part of much of Christianity in Africa. As Kaoma writes,

through their extensive communications networks in Africa, social welfare projects, Bible schools, and educational materials, U.S. religious conservatives warn of the dangers of homosexuals and present themselves as the true representatives of U.S. evangelicalism, so helping to marginalize Africans' relationships with mainline Protestant churches.

The champions of religious renewal in Africa promote generally accepted values such as respect for lives and harmony in families, but they also demonize the body, alienating humans from themselves by insinuating a mythology that, in most cases, successfully displaces a person's experience of his or her embodiment.

Uganda has been the testing ground for the Evangelical battle for the African soul. The departure of Idi Amin and the subsequent brutal power struggles that plunged the country into further dysfunction left a wide gap for any savior, and the Evangelical movement quickly filled the gap. The film God Loves Uganda by Roger Ross Williams engages with the activities of Evangelical missions in the 1990s. It examines, among other issues, the role of Scott Lively, who had in the past made such wild claims that the Nazi Party and the United Nations were plots by homosexuals to take over the world (Blake 2014). Commenting on the film, Jessica Boutchie (2019) observes that:

the early 2000s also saw an influx of Christian missionaries from evangelical Christian organizations like the International House of Prayer. In 2010, Lou Engle, a former senior leader at IHOP and the founder of The Call Ministries, traveled to Uganda to host a rally discussing the alleged evils of homosexuality. Engle also used his platform to praise Ugandan politicians" "courage" and "righteousness" in promoting the Ugandan Anti-Homosexuality Act of 2009.

One of the lasting institutions created by the American Evangelical movement in Uganda is Uganda's Family Life Network (FLN), which was founded in 2002 with the goal of promoting what they called family values, and to restore "strong families and youth with strong morals and character, through the promotion of value based morals and life skills across the population regardless of gender, race, ethnic, social or religious background" (Family Network n.d.). The organization became a breeding ground for 
anti-homosexual zealots including many members of the parliament. For example, as Kaoma (2009b) writes, "In March 2009, Scott Lively, the Holocaust revisionist and author of The Pink Swastika, warned Ugandans that gays posed a dire threat to their children and society."

Scott Lively and his fellow American Evangelicals were instrumental in Uganda's foray into criminalizing homosexuality with the introduction of an infamous bill in 2009 that prescribed death penalty for anyone found to be engaging in homosexual activities. The proposed bill provoked international outcry, and it was subsequently removed from the political agenda, but it was revived in 2013, and, on February 24, 2014, Ugandan President Yoweni Museveni signed it into law (Karimi and Thompson 2014). By this time, it was no longer a solely Ugandan issue; other African countries had taken notice (Gettleman 2010).

As Nathalie Baptiste (2014) has documented, the epidemic of hate against people of alternative sexualities has spread all over Africa. There have been many religious groups propagating this hatred besides the FLN. A known example is the "pro-family" advocacy group Family Watch International (FWI), which was formed in 1999 and headed by Sharon Slater. Baptiste reports that:

Slater was the keynote speaker at a meeting of the Nigerian Bar Association, where she touted her beliefs about homosexuality, telling delegates that they would no longer have religious freedom and that homosexuals would prey on their children if they supported "fictitious sexual rights."

In the early months of 2014, Nigeria enacted a law against homosexual life in the infamous Act titled, "Same Sex Marriage (Prohibition) Act, 2014." It was framed as an "Act to prohibit a marriage contract or civil union entered into between persons of same sex, solemnization of same; and for related matters" (Centre for Laws of the Federation of Nigeria 2013). The Act mandates up to fourteen years of imprisonment for those who cohabit, or contract gay marriages, and ten years for those who promote any form of gay activities or lifestyle. Since then, there have been numerous cases of violence against homosexuals, often ending in death (Human Rights Watch 2016).

At the 1995 Zimbabwean Book Fair, the erstwhile Prime Minister of Zimbabwe, Robert Mugabe argued that protection of gays from violence was not a human right because homosexuality was unnatural. According to Chris Dunton and Mai Palmberg (1996:8), some other questions raised during the debate that ensued after Mugabe's intervention were whether the universality of human rights applied in Zimbabwe and whether homosexuality was natural or an imported Western phenomenon. In his opening speech for the book fair, Mugabe dismissed the notion that homosexuality ought to be accepted. He stated:

I find it extremely outrageous and repugnant to my human conscience that such immoral and repulsive organization, like those of homosexuals 
who offend both the law of nature and the morals of religious beliefs espoused by our society, should have any advocates in our midst and even elsewhere in the world.

Of relevance to my discussion here is Mugabe's justification for not extending human rights to people of alternative sexualities and how in him religion and politics have melded to create an environment of human rights abuse. ${ }^{1}$ He relies on the "Law of nature" and "the morals of religious belief." This is a particular case of the appeal to nature fallacy, but it is also particularly fallacious because homosexuality occurs in nature, is natural. In their political support for Mugabe, some members of the ruling ZANU-PF and the Women's league issued a statement declaring that "human rights should not be allowed to dehumanise us" (12). It is ironic that they described human rights, a principle designed to affirm the inherent dignity of every person, as capable of dehumanizing Zimbabweans. There is here a fundamental disconnect between consideration of the dignity of individuals as human beings and what is constructed as social order, which is indeed the ideological extension of the desire of the privileged members of society. Mugabe's argument has precedence in history. Presidents Daniel arap Moi of Kenya and Julius Nyerere of Tanzania had made the same arguments years before (24).

The consequence of mixing of religion and politics regarding homosexuality is the immediate scapegoating of members of the LGBTQ community. For example, in Nigeria, there are now vigilante groups who hunt for people suspected of engaging in "gay activities" (PBS News Hour 2015). Richard Akuson (2019) writes about the human rights abuses that:

many Nigerian gay men have too often experienced in the form of lynchings or pillory with tires before they're set on fire and burnt alive-not for terrorism or worse, but for being gay, for being human, in a desperately homophobic country.

These people of alternative sexualities are considered sacrificeable to avert an imagined greater calamity in society.

\section{Homosexuality and African literature}

The notion that homosexuality is foreign to Africa has also held sway in the African literary imagination. This has until recently largely accounted for the absence of decidedly homoerotic characters in African narratives. Some of the narratives that deal with homosexuality in Africa engaged with the topic rather indirectly, in some cases to mock African denial of this aspect of being human. Wole Soyinka's novel The Interpreters is one such narrative. In this story, Joe Golder, an African American professor teaching in Nigeria, is the one who informs his Nigerian interlocutor, the journalist Sagoe, 
that homosexuality exists in Nigeria, providing him with convincing anecdotes, and yet Sagoe responds in a typical denialist way: "You seem better informed than I am. But if you don't mind I'll persist in my delusion" (Soyinka 1996:199). Through Sagoe Soyinka mocks Africa's persistent hollow claim that Africans cannot be homosexuals, when, in fact, homosexuality is not a racial or cultural phenomenon; it is human. Chris Dunton (1989) offers a more extensive discussion of Soyinka's novel as a pioneering text that deals with homosexuality in Africa. Neville Hoad (2007) examines the contentious public debate on the "Africanness" of homosexuality. He also discussed Wole Soyinka's The Interpreters as one of Africa's pioneering novels to engage the taboo issue.

Even twenty-five years after this important observation, many African scholars, perhaps representing the majority of African population, still consider homosexuality to be a Western thing. Allwell Abalogu Onukaogu and Ezechi Onyerionwu (2009:130) complain that "the Nigerian twenty-first century novelist has exhibited astonishing liberties in the area of blatant depiction of sexuality." They discuss in particular Jude Dibia's Walking with Shadows, asserting that "No Nigerian novel present or past has taken such a sacred and blasphemous tangent that has found a home in the West" (131). Of note here are the idioms that the authors use to engage with Dibia's unapologetically homoerotic narrative. Their use of religious language reveals not only their ideological bias but is also representative of the temperature of intolerance.

It is not my intention here to engage in a detailed outline of the representation of homosexuality in African literature. Lindsey Green-Simms (2016) provides a good overview of such in Nigerian literature. My concern here is to explore the structure of politics constructed on the body of the other, who is conceived as a scapegoat. The other part of my concern is the representation of queer bodies as deserving to be seen just as the ordinary bodies that they are. As such they deserve the same dignity that others within the normative realm enjoy. The issue therefore is the question of the body as a space of politics; it is the question of who has right to control individual bodies.

Nathalie Baptiste (2014) has noted that for the antigay religious activists, "the rights of LGBTQ people are imaginary." Kenyan American legal scholar Makau Mutua (2011:452) argues that the revulsion toward homosexuality can be traced to Christianity and Islam, "the two religious traditions that express homophobia in their doctrinal teachings." He states that "homophobia has long been a hallmark of the two Abrahamic faiths" (452). Perhaps the noun "hallmark" seems a bit too harsh to designate these two religions, which are known for more things than their rejection of homosexuality. But Mutua is right to identify the said two religions' inflexible positions on gay rights as intimately linked with these messianic faiths that are notoriously motivated by a teleology of apocalypse. For one fixated on apocalyptic eschatology, individual human beings are mere pawns in the grand scheme of things. It becomes difficult, if not impossible, to convince 
people with such mindsets to accept the dignity of every individual regardless of religion or sexual orientation. This is perhaps where narratives of bodies in pain can help (Scarry 1988).

The advantage of narratives of individuals who identify as gays and lesbians is that such narratives situate the fight for acceptance in the lifeworld of concrete, embodied individuals. Narratives cut through the jabber of ideologies. If stories can convince enough people in society to imagine the pain of others, there might be just enough people in society to understand the need for laws that grant members of the LGBTQ their right to be who they are. I have argued that narratability makes concrete the universal and universalizes the concrete and that the condition of narratability is that the story must arise from the human condition, and it must be based on the practice of the ordinary; only that can make the characters relatable and capable of exciting our sympathy. I have also proposed that all human rights discourses in Africa begin with the body - the body that feels pain and pleasure, the body that must not be violated, and the body that must be respected as if it were one's own.

\section{Stories and ownership of queer bodies}

The defeat of the first (2009) bill to criminalize gay activities in Uganda did not prevent the killing of gays and lesbians. This unfortunate effort, provoked and supported by American Evangelicals seeking to spread their ideology in Africa, however, put the gay community on notice. Well before the introduction of the bill, though, David Kato, a Ugandan gay activist, who was living in Johannesburg, returned to his home country to help organize a movement to educate Ugandans about that basic fact of human sexuality and of the human condition. Call me Kuchu ${ }^{2}$ is a documentary film based on such efforts by the members of the LGBTQ community to draw international attention to the treatment of homosexuals in Uganda. David is murdered by an antigay religious zealot. The film blurb goes to the heart of the narrative:

David fights Uganda's government and tabloids in the courts, on television, and at the United Nations. Because, he insists, "if we keep on hiding, they will say we're not here." But no one is prepared for the brutal murder that shakes the movement to its core and sends shock waves around the world.

(Wright and Zouhali-Worrall 2013)

David Kato becomes the fulcrum around which the stories of others revolve. His honesty and untiring activism inspire others to tell their coming-out stories. In other words, Kato becomes a catalyst that prompts others to first recognize themselves for who they are and to stand by it. My interest lies in the narrative arc of these people with alternative sexualities. 
I argue that their activism and their stories have one simple goal: to situate their bodies as none other than theirs and as deserving of rights and dignity as other bodies do because they are humans. Their stories read like a call for all to take article 1 of the (UDHR) seriously. In other words, they urge society to abandon the abstractions of ideology and teleology and engage them as fellow humans situated in space and time and not meant for a specific goal.

As Call Me Kuchu begins, we are introduced to David at his home, at the end of a dirt road. We see him cultivating his garden and husbanding his animals; we see him living his life the way all humans do. He tells us about his life. He had been confused about his sexuality because he had no reference point to help him understand what had been going on in his life and why he was attracted to men and not women. He finally discovered his sexuality in South Africa at the age of twenty-eight, when he saw other men living out what his imagination had been too timid to formulate. As a result, he was inspired to return to Uganda specifically to liberate his people, that is, to let those, who were living the kind of life he had lived before traveling to South Africa, know that their feelings were exactly right. There, he began an initiative to fight cases of discrimination and violence against gay people.

The most outstanding feature of David's story is its narrative form. It is not forced; it is merely like hearing the story of any heterosexual person discovering an aspect of his or her body he or she had not been aware of and which does not infringe on the life of any person. It is the simple story of self-discovery and affirmation, and it is precisely this aspect of his story that links it with those of the other members of the kuchu community.

Naome Ruzindana is a lesbian. Her true identity as a lesbian is known only to the LGBTQ community; in the society at large, though, she is simply known as a human rights activist who performs the role of a middle-person building a bridge between the public and the LGBTQ community. Naome had always felt that her sexual orientation was queer, but she had believed she could suppress it. She even had a boyfriend and got pregnant by him and the pair married. However, she never felt any sexual attraction to him, or to any man, and she walked away from the marriage after five years of trying to be heterosexual. On the wall of her house hangs a pennant bearing the inscription: "By God's Grace I am What I am." 1 Corinthians 15: 10. The pennant is her plea to the world to see her and accept her the way she is. It is striking that she cleverly makes her statement in the idiom the people are familiar with, in that of the Christian narrative. It is, however, questionable whether her people would heed that plea given their ideological frame of mind. For the viewer, the two stories thus far convey an air of authenticity. One can see that the people are merely telling the stories of who they are, not the stories of who they chose to become. So, the outstanding message here is that their sexual orientation is not a choice, and just as people are born with different skin colors, heights, and genders, so are they born with different sexual orientations. ${ }^{3}$ 
The third narrator, Stosh, a trans-man, tells of a corrective rape he endured as a teenager at the hands of a man who worked in her grandparents' farm. The man had caught her having an intimate relationship with a girl. He said he would teach her what she was supposed to do with a boy and subsequently raped her. She became pregnant, but the child was aborted because Stosh was too young to carry the pregnancy to full term and to take care of the child. Compounding her misery, the man infected her with HIV and she attempted suicide. Stosh concludes her story: "Maybe I was supposed to live for a reason, for a purpose. People want to know our stories. That's one reason I decided to come out."

The three stories have two levels of appeal: the purely existential, which is the right to exist as a human, and the ethical, which is the right not to be hurt because of one's difference. Admittedly both rest on the need for recognition. These people tell their stories because they desire justice from their world.

Many people in the world do not need to see others in pain in order to grant them the human attention and the right to be who they are. Many others, however, need to understand the degree to which their actions and beliefs inflict pain on others. Instances of the abuse of human rights such as corrective rape and infection with HIV/AIDS ought to move them to raise questions about their relations to their fellow humans. The three stories operate on the level of a narratability test. They make human rights and human dignity immediately palpable and challenge others to respond to the condition of queers, especially given that they require nothing of society than to be left alone to live their lives. David, Naome, and Stosh narrate human rights because their stories establish the body's moral sphere and therefore the inviolability of its dignity. The issue therefore is not that their lives are in danger, which is the case. The issue is that they perceive themselves as having no dignity in their community just because of their difference. Their narratives seek to alert their world of that dignity.

Call me Kuchu is ethically informed as it is aesthetically pleasing. Indeed, aesthetics is carefully put to the judicious service of ethics. The producers, Katherine Fairfax Wright and Manila Zouhali-Worrall, achieved maximum aesthetic and ethical effects by juxtaposing scenes. First, we are shown the group of queers celebrating their lives; then we encounter a group of Evangelicals steeped in religious fervor and swearing hellfire on homosexuals. Then we hear stories of individuals struggling with their identities. One of the contrasting scenes is that of one Pastor Moses Solomon Male invoking an imaginary apocalyptic scenario that is sure to come if gays and lesbians are not eliminated from Uganda. He claims that the youths are being taken advantage of; that they are being lured into homosexuality. He yells: "Victims are sodomized every day." Pastor Male's recourse to abstractions and hyperbole is, of course, not a surprise, as these are typical traits of a mind steeped in mythological thinking. The constant reference to Sodom and Gomorrah recalls Girard's thesis: "all myths have their roots in real 
acts of violence against real victims, and the need to avert greater calamity" (Girard 1989:25). Pastor Male seems to believe that killing gays and lesbians would prevent any impending Armageddon.

Another instance of paralleling of those devoted to abstractness on the one side, and people who live their lives, on the other, is the encounter between Giles Muhame, the managing editor of Rolling Stone, and David Kato. ${ }^{4}$ Both are as opposed to each other's position in life as could be imagined. Muhame is a rabid homophobe, who rouses people to hatred by publishing pictures of gays and lesbians and urging people to hang gays. In one of such occasions, shortly after El Shabaab militants carried out suicide bomb attacks against crowds watching a screening of the 2010 FIFA World Cup Final, the tabloid spread false information, alleging that gays were behind the bombing. It also alleges that gays want to overthrow the government. Of course, any average reader knows that David Kato and the members of his community, who barely make ends meet, cannot achieve such a dastardly feat. Yet the tabloid is able to cleverly exploit the atmosphere of fear to sow further seeds of hatred in peoples' minds.

Also tempering the noise and hollowness of the fiery preachers is Christopher Senyonjo, an octogenarian retired Anglican Bishop. Bishop Senyonjo, too, invokes the Bible, but in his case, he does so to assert the uniqueness of the lives of the members of the LGBTQ community. In one of his counselling sessions, he quotes Saint Paul's letter to Galatians: "There is neither Jew nor Gentile, neither slave nor free, nor is there male and female, for you are all one in Christ Jesus" (Galatians 3:28).

The figure of the bishop is of critical importance in the emerging narrative surrounding LGBQ community. He makes them appear ordinary, that is, normal. He de-exoticizes them. First, he lets us understand that he is not gay, which disposes us to see his engagement with them as purely disinterested and therefore has high moral credibility. He works from the perspective of a universal moral framework, but then we grasp that he fully understands the condition of the LGBTQ community. However, for his solidarity with them he was excommunicated by his church. For me, therefore, he represents the majority of people of good will, who may never have come in contact with any member of the LGBTQ community but who are open to engage them in humanly more fulfilling ways.

By juxtaposing scenes of concrete lives with those of people whose operative modus is the abstract world, Wright and Zouhali-Worrall challenge us to judge the situations presented to us and to relate to humans according to our judgment. In the above instances of parallelism, the film successfully situates the lyricism of the life stories of those duly aware of their vulnerability with the passion and noise of the worshippers, some of whom bay for the blood of scapegoats.

At David's funeral, the bishop emphasizes what could be called the underlining thread in the narratives of the members of the kuchu community. He states that God created David the way David was. Kuchu are Christians, 
regular humans who go about their Christian lives like all others. They are brought together by their awareness of the vulnerability of their lives. As they face constant threats to their lives, they know that they have to come together and strengthen each other's humanity. Their grief, hope, and dreams are presented as ordinary as the grief, hopes, and dreams of all other humans. This is what draws us to them.

Call Me Kuchu was conceived in the spirit of narratability of human rights. It believes that the only way to make people understand a thing is to present it to them. We hear members of the LGBTQ community say, "we are here, we too are humans." We hear them demand justice. Of far-reaching relevance, and, indeed, what remain with us, are the stories that they tell one another and the world. As Kay Schaffer and Sidone Smith (2004:3) explain,

Stories provide necessary evidence and information about violations. They put a human face to suffering. They command international attention, spurring the interest of NGOs and the media, building awareness of events at home and in other parts of the world.

The film reveals one fundamental thing about the lives of homosexuals in relation to human rights. Regardless of whether Uganda is a signatory to the UDHR or not, regardless of the state of law in the country, what counts at this point in time is whether the ordinary people recognize gays as humans deserving to be respected in their difference. This is what the film seeks to achieve. After David Kato's burial, and surprised by the international response, Giles Muhame expressed surprise that people all over the world hailed Kato as a hero. He states, "People need to know that human rights does not mean gay rights" (Wright and Zouhali-Worrall 2013). He, sadly, reveals a fundamental misunderstanding of human rights and what it means to be human. He represents a majority of the population in Africa who see human rights as a Western thing. But it is not, and the plight of the members of the LGBTQ is as much about simple survival as human beings as it is about dignity.

\section{The body as the lyrics of life}

The laws against homosexuality in Uganda and Nigeria unleashed a wave of hatred of people of alternative sexualities. According to the editors of Kuchu Times, an online forum formed in Uganda in the aftermath of the death of David Kato, "On 18th February Nigerian citizen Akkinifesi Oluide Olubunmi passed on after being attacked and viciously beaten the previous day. Akkinifesi was sent to an early grave by a mob that lynched him on suspicions of being gay" (Kuchu Times 2016). Like in Uganda, members of the LGBTQ community in Nigeria and other African countries have woken up to the fact that their very existence as human beings are under threat and they are no longer content with living in the closet and denying their 
sexual orientation. I have already mentioned Jude Dibia's novel Walking with Shadows, which has attracted considerable scholarly attention. Romeo Oriogun (2017) is a Nigerian queer poet, who describes his parentage as a mix of Yoruba and Edo. He is the winner of the 2017 Brunel International African Poetry Prize. Some of his poems are obviously hewn from his life as a gay person in a largely heterosexual and homophobic society.

The title of the poem "Invisible Man" is a nod to Ralph Ellison's famous novel of the same name. With this poem, Oriogun identifies with Ellison's narrator, who speaks from his underground hideout in the basement of a whites-only apartment. Ellison's story is, in turn, a tribute to Dostoyevsky's existentialist novel, Notes from Underground. Well situated in the existentialist tradition of both novels, Oriogun's poem gestures to the undying question of the place of the individual in an absurd world, a world that has no place for difference. Ellison's protagonist lives in a world dictated by the whims of white racist mythology; he is invisible but desires to be seen. The same goes for Oriogun's speaker, whose world has been relegated to the coal cellar of a homophobic society, and who cries to be heard. The first two lines bring a boy and a bird together to create a potent metaphor for entrapment and the desire for liberation: "And the voice was a lost bird embedded in a boy / like a word stranded between pages." The lost bird embedded in a boy is a caged bird, an allusion to Paul Laurence Dunbar's poem, "Sympathy," made popular by Maya Angelou in her memoir, I Know Why the Caged Bird Sings. We are given a glimpse into the psyche and emotional state of the speaker, especially in the third stanza:

The radio said, a father shot his son for loving another man.

Marvin Gaye lives in the heart of a black drag queen

and to be a song of pebbles and water is to run into a city of light and surrender your throat to the song of a bird.

(Oriogun 2017)

We have thus two principles clashing against each other: freedom and death, each as strong as the other. We are reminded of the tragedy of Marvin Gaye's death, killed by his own father, Rev. Marvin Gaye Sr., 70, an Apostolic minister. The speaker is crammed between these two worlds, just as a word is stranded between pages and as is the caged bird. If we have not already divined what torments the bird (i.e., why that caged bird sings), then the seventh stanza makes it more than clear:

Wet dreams:

a boy hears the whisper of another boy deep in his bones

and wonders about the origin of stars,

his body is a lamp learning how to give light

in a place where a boy opens his mouth

from the door of a tomb;

where a boy takes his first breath. 
It is not surprising that the speaker wants to know the origin of stars. He is yearning for a boundless freedom and boundary-transcendent solidarity. Paul Laurence Dunbar and Ralph Ellison, of course, wrote about the cage to which African Americans had been consigned. In making subtle allusions to both, Oriogun exposes an existential and universal yearning for a boundless world, a yearning to escape a closed system. He juxtaposes this yearning, which is the most natural, life-affirming thing, with being in cage and death, which are the opposite of life. It is as if he would challenge us to take sides. This ethical challenge is enhanced in the next poem, "Elegy for a Burnt Friend," which expresses the condition of Africa understood as a closed system. It is a one-stanza poem in which the powerlessness of the speaker is powerfully expressed in the following lines:

There is nowhere to say enough, nowhere to breathe in the open sea without salt stinging your throat; nowhere to wash our body in water and become free.

It is heartrending to realize that the speaker desires only to be allowed to be free and human. This is obviously impossible or very difficult, given the narrow conception of being in society. He is not seeking to redefine Africa; he is asking people to accommodate his difference, to grant him the recognition and justice they grant themselves.

"How to Survive the Fire" has one dominant idea, expressed in the last two lines: "before you understand why God turned // his face from Christ and whispered, run." The idea is the fragility of life, which is expressed in the conundrum of God telling a nailed Christ to run for his life. Where would Christ have run to when he was already nailed to the cross? The fitting metaphor of Christ being abandoned, or not being helped by God despite God's omnipotence, completes the picture of a closed system that is markedly against life, a system in which love of life and human flourishing had been extinguished in people by a corrosive mix of traditional and Christian fundamentalist mythologies. In painting the picture of a closed world, Oriogun urges the need for a more expansive reality, or at least for a redefinition of the known world that allows for differentiation.

The poem "The Origin of Butterflies" is just about human flourishing to which all humans aspire. It is a one-stanza poem whose core discourse is made explicit in these lines:

Last night I saw a butterfly

break darkness with the colours of her wings,

she rose gently to the moon with songs

within her body.

Oriogun situates the speaker's mood on the brighter side of life. It is important that what breaks the darkness surrounding the speaker's world is 
something as dainty, vulnerable, and harmless as the wings of butterfly. Equally important is that the butterfly rises to the moon "with her body." It is the resurrection of the body, not of the soul. It is a subtle reference to the desire innate in the bodies of homosexuals just as it is in those of heterosexuals. This desire is as harmless as a butterfly, and it does not stand in the way of society. Oriogun is interested in the triumph of the body as it is. This is made more explicit in the last ten lines of the poem:

There is a place where butterflies live-mother said happiness can come from sadness.

On the next page of my life

I wrote only one word: Happiness.

I watched it grew from my book (sic)

and broke the night into fragments of stars.

Someone once said, when the sun is dead

we take light in small sips.

I do not know what it means,

I only saw stars falling as butterflies.

The core of the speaker's life is seen in the pursuit of the very idea that his mother put in his head: happiness. In Oriogun's understanding, human flourishing must be like butterflies in the field which destroy nothing but which live as fulfilled a life as they can. A fulfilled life is lived in the present, not in the abstraction of collective identity or in the thereafter.

\section{Uses and abuse of difference}

I established in Chapter 1 that Paul Ricoeur's idea that a plot serves to make one story out of multiple incidents. Plot transforms the many incidents into one coherent story, and, to understand the story, or if you like, the life of a person, one has to take the many incidents into account. No single incident holds the key to understanding the entire story. Rather, one has to move from one incident to another and compare them against the backdrop of the whole (Ricoeur 1991:21). In carefully laying out the details of a story and bringing together the various aspects of a particular life in such a way that they make a coherent narrative, stories compel a certain understanding of the world. This understanding is in response to the implicit question raised by the character whose life is being laid out in minute details. Such questions include: Can you feel what I feel? Can you understand why I am this way rather than the other?

Chinelo Okparanta writes in the Aristotelian tradition mapped out by Paul Ricoeur. She belongs to the third generation of Nigerian writers, sometimes casually referred to as Chinua Achebe's children. But her works are as far removed from Achebe's aesthetic and ideological concerns as is her generation from Achebe's. Whereas Chinua Achebe was very much concerned 
with writing back to the center and thereby proving the humanity of Africans, like most writers of her age, Okparanta is much more concerned with the well-being of individuals. Happiness Like Water (2013), a collection of short stories, reads like a lyrical exploration of interpersonal relationships. More specifically, she explores the contours of personal happiness of her female characters who are mostly of Igbo ethnic extraction in Nigeria. Elsewhere (Eze 2016), I have explored some of her short stories as typical of bold feminist writing because of their examination of the fate of women in a rampantly patriarchal culture. There, I purposely skipped discussing the specific stories dealing with the concerns of lesbian characters, not because I was ignorant of intersectionality but because I wanted to focus on exclusively feminist concerns to the degree that they relate to men in general.

Okparanta introduced her audience to LGBTQ concerns in her short story "America." In this story, Nneka and Gloria are lesbians. Nneka's parents catch them making love and warn her that "there are penalties in Nigeria for that sort of thing" (Okparanta 2013:89). Gloria settles in America and is a successful economist. Nneka eventually rejoins her after several hurdles, and they are able live their lives freely. In another story, "Grace," the characters, Grace and the narrator, a middle-aged professor of Igbo ancestry, who fall in love and confide in each other the harsh reality of their having to marry men even though they never felt sexual attraction to them. Grace is twenty-two; she is about to marry Obinna, a man from her ethnic group, and she is scared. She doesn't love him, or any man. Instead, she loves women. Grace's condition reminds the professor of her own; she, too, had married a man even though she is a lesbian. Thankfully both she and Grace are able to express their love to each other and promise to be in love as long as it is hidden from their families. Mythili Rao (2013) calls Okparanta a "Champion of the Stifled." I endorse this qualification. As the foregoing discussion reveals, my interest in the representation of homosexuality in African literature lies in the degree to which it reveals the human rights struggles of the members of the LGBTQ community in Africa. Expressed in the words of Rao, it is to the degree that their lives are stifled or rendered disposable by their world. The novel, Under the Udala Tree, is an extended study of the stifled lives introduced in her short stories.

Under the Udala Tree is the story of one woman's struggle to escape the boundaries set on her life by her culture. Part One of the five-part novel is set during the period of war between the Igbo and other ethnic groups of Nigeria (1967-1970). Impoverished by the war, Ijeoma and her family hardly make ends meet. Ijeoma's mother sends her to the town of Nnewi as the house-help to a grammar school teacher. She herself goes to work in Aba, one of the rising industrial cities. At Nnewi Ijeoma meets Amina, from the Hausa ethnicity, one of the many others fighting against the Igbo. Amina had lost all the members of her family during the war. Ijeoma introduces Amina to her host family, which takes her in after initial hesitations because of Amina's ethnicity. Ijeoma and Amina fall in love. The 
teacher catches them making love, which he considers to be an abomination. $\mathrm{He}$ sends Ijeoma to Aba while Amina continues to stay with him because she has no family. Per chance Ijeoma and Amina meet again at a boarding school, long after the war, and they revive their sexual relationship. However, Amina later gets married to a man from her ethnicity, and Ijeoma too is forced into marriage by circumstance, despite her not feeling any sexual love for men. After living with her husband, Chibundu, and giving birth to two children, only one of which survives, she finally summons her courage and leaves the marriage.

Ijeoma's story is similar to Naome's in Call Me Kuchu. The novel rightly fits into the Bildungssroman genre as explicated by Joseph R. Slaughter (2007:3) in Human Rights, Inc: The World Novel, Narrative Form, and International Law. Slaughter is not necessarily interested in the plot which, he argues, "we could provisionally gloss as the didactic story of an individual who is socialized in the process of learning for oneself what everyone else (including the reader) presumably already knows." Instead, he is more interested in how the Bildungsroman "articulates certain social relations" (7). Examining the genre's social function, Slaughter argues, helps us understand the relationships between the languages of literature and law. My interest in this particular coming-of-age novel lies in the fact that it highlights the social structures that stifle the dignity of the individual. What do those social relations reveal about human rights?

We recall Lynn Hunt's argument that eighteenth-century European sentimental novels by authors such as Jean-Jacques Rousseau and Samuel Richardson helped to provoke the early stirrings of thoughts about universal human rights. What Slaughter's and Hunt's discussions have in common is the notion that the narratives are essentially sentimental and often didactic. Okparanta's coming-of-age novel is far from being sentimental or didactic. In fact, it is artistically sophisticated, delineating the conditions that undercut a particular individual's dignity and mitigate against human flourishing. Ijeoma's recollection of the war and the destruction left in its wake establishes an overarching metaphor against which the rest of the story is to be understood. Within that framework, the stifling postwar period becomes a navigational tool for the whole novel that describes the conditions from which Ijeoma has to liberate herself. Right after her father was killed during an air raid, the narrator, presaging the rough road ahead for the remaining members of the family, shrewdly explains the meaning of her name-_Ijeoma (which was just a wish: 'safe journey')" (Okparanta 2015:21). It would indeed be a long journey of self-discovery and consequent self-affirmation as a person whose sexuality lies outside the heteronormative structures. Her name is, indeed, a short definition of the Bildungsroman.

With her family's increasing hardship and widespread hunger Ijeoma's mother begins to see her as a burden, and she makes plans to get rid of the girl. Indeed, her mother sends her on a literal journey, to Nnewi. By 
inserting Ijeoma's personal story, her simultaneous journey across land and to her self-awareness in the war-torn environment, Okparanta prepares the reader for the kind of battle Ijeoma is going to engage in shortly, the battle for self-affirmation. Perhaps the true journey of self-assertion as a lesbian in Africa is like surviving a war.

Okparanta exposes forms of difference and the uses to which the normative imagination of their culture puts them. She sets the story of this young woman with a different sexual orientation against the backdrop of which is ethnic difference. Ijeoma's mother is vehemently opposed to any relationship with Amina because she hails from the Hausa, a different ethnicity than the Igbo. It does not matter to Ijeoma's mother that Amina is a victim of the war, having lost her entire family to an air raid attributed to the soldiers from her ethnicity. From the look of things, it therefore makes no sense that Ijeoma's mother would be against any affinity between Ijeoma and Amina, two victims of the same war. If this does not make sense to the reader, Okparanta seems to be suggesting, it also should make no sense that Ijeoma's mother would be against their sexual orientations either. According to her logic, therefore, sexual orientation is just like being born into an ethnic group.

What counts here is not necessarily that Ijeoma's society does not accept her the way she is; it is the justification that it uses to stifle her expression of her being. The justification is rooted in the biblical myths, and, thus, we see mythic consciousness standing in the way of people engaging with reality the way it actually is. Ijeoma's mother prepares Ijeoma's mind to accept the normative truth about human nature and sexual orientation, which is that people of the same sex are not supposed to have intimate sexual relationship with one another but rather with people of the opposite sex. She begins with reading from the book of Genesis, and specifically about the creation of heaven and earth and then of Adam and Eve. Ijeoma's mother condemns Ijeoma's love affair with Amina because it does not fit with the biblical injunction. She states: "It's that same behavior that led to the destruction of Sodom and Gomorrah, the very same behavior you and that girl-what's her name again? - engaged in" (73). Her mother cites the book of Leviticus 18: "Thou shall not lie with mankind, as with womankind: it is an abomination" (75).

As I have sought to establish, in Chapter 3, mythic consciousness construes the world in simple binaries and relies on imagination rather than on sensory perception to explain it. Mythic consciousness reaches into an imagined reality that cannot be challenged by logic because it relies on tradition (ancestors in the case of oral cultures) and authority, including canonized texts such as in the Bible. Mythology is thus a mechanism through which identity is weaponized.

In The Colonizer and the Colonized, Albert Memmi (1990:123-133) shows that one of the most effective means through which the colonizer maintains power is by creating a negative image of the colonized. The colonized has 
to be radically different from the colonizer, which allows the colonizer to avoid seeing the colonized as humans, and, therefore, they have no qualms in violating the colonized. Second, the invention of the negative image of the colonized helps the colonizer to control the colonized psychologically. The worst part of colonial conquest therefore was the imposition of negative images on the colonized on themselves, for without it imperialism would not be possible. These negative images were sustained by the stories that the colonizers told about the colonized, but the exploitation of difference is not restricted to only colonial societies; it is also an effective apparatus of control in postcolonialist religion as well as in secular dimensions of power (Anzaldua 2012). Ijeoma's mother stands for the majority of her society who rely on mythic consciousness for their judgment of the world and who are against homosexuals. As in Call me Kuchu in which Pastor Moses Solomon Male relies on the Bible to argue that homosexuality is un-African, Ijeoma's mother has no other argument than to repeat the biblical myths. She is one of the obstacles that Ijeoma had to surmount if she is to arrive at selfknowledge, which is what a Bildungsroman is all about.

Ijeoma seems to have the ability to deconstruct the biblical myths. The book of Judges tells of the men who presented their daughters to be raped instead of themselves. Ijeoma questions the courage and wisdom of such men, who rather than protect their daughters, sacrificed them. She asks herself, "What if all these stories were actually only allegories for something else, something more than we could easily put our fingers on?" (Okparanta 2015:80-81). However, the greatest deconstruction of the abstraction of mythology is her insistence on her own lived story. She argues that even though God meant for there to be Adam and Eve rather than Eve and Eve, there is no way she can explain what she feels other than to say that it is also what God created. She is as aware of her feelings as she is of the world revealed by her senses. She says,

But we were in love, or at least I believed myself completely to be. I craved Amina's presence for no other reason than to have it. It was certainly friendship too, this intimate companionship with someone who knew me in a way that no one else did.

In insisting on the tangible details of her life, she reveals a solid sense of self, a sense of her dignity. Human rights are about protecting that moral sphere.

In Ijeoma and Amina, Okparanta presents two characters exposed to the same mythologies but who react differently and therefore reveal varying effects of the ideologies that are imprinted upon them. Whereas Ijeoma is able to counter the biblical mythologies with a robust awareness of her selfhood, the same cannot be said of Amina. She cannot produce any narrative to 
counter that of her society, and so she becomes a victim of the normative construct that the mythologies serve. For example, once after they have made love and fallen asleep by each other's sides, Amina has a chain of uncoordinated dreams. She dreams of a golden horse chariot with no horseman. "People are lining up, marching toward the bright light that encircled the carriage in the sky" (155). A revealing aspect of Amina's dreams is the appearance of hailstones "and fire, pouring down and forming craters where they landed" (155). Amina makes a direct connection between what she and Ijeoma have done and their impending destruction; they are doomed to be destroyed as the cities of Sodom and Gomorrah were because she and Ijeoma were engaged in "sodomy." After the dream their friendship gets sour, and Amina starts avoiding Ijeoma who tries in vain to get her back. Since Sigmund Freud, we know that dreams issue from the $I d$, a warehouse of repressed instincts seeking discharge; it is where our fears, desires, and libido are encoded. Society controls individuals by tapping into the $I d$, especially with their myths and sacred texts.

We recall Joseph Campbell's (1988) discussion of the functions of mythology (Chapter 3), especially its power to regulate social hierarchy. It is a way of maintaining order and thereby preserving conventional knowledge of the world and therefore power in the hands of those who already wield it. In Amina, we see the sociological function of mythology as a technology of power. In this case, it has effectively interpellated Amina, who had consumed it without differentiation. Because of the control that the narrative exercises in Amina, she is alienated from her body and does not believe that it belongs to her. Instead, it is objectified and belongs to society; that is, it must be understood in the grammar of traditional society and its patriarchal logic. She would eventually suppress her feelings and marry a man from her ethnicity. The euphoria with which Ijeoma's mother and the grammar school teacher greet Amina's marriage and the words with which they describe it reveal their underlining ideological disposition. Ijeoma notes that her mother "seemed appeased that Amina had at least known to marry into her own tribe" (Okparanta 2015:170). The teacher "nodded with the overenthusiastic effort of a person trying hard to keep things jovial. 'Indeed. With her own kind. It couldn't be better', he said" (170). Ijeoma's mother and the teacher see the world and human relationships through the prism of nature. They believe in hierarchy and order, in the division between purity and impurity and the vital necessity of keeping them apart. Ijeoma's mother makes a complacent pronouncement in that regard: "It's just the way things are done" (171). Okparanta seems to suggest that those who maintain racial and tribal separateness, that is, a kind of separate but equal ideology, are more likely to argue for the normative understanding of sexual orientation and to consider anything outside that norm as a deviation and therefore disposable. However, the human condition is more than normative human nature. 


\section{Normativity and the violence of categorization}

How does a racist, sexist, or homophobic system disable the bodies of the members of its vulnerable groups and eventually produce disposable bodies? Disposable bodies are those that are overdetermined by the system whose operational paradigms constrict the freedom and functions of the bodies that fall outside the norm. The system disables the bodies of the vulnerable members of society, to use Iris Marion Young's (1980) terminology. The system raises the functions of the bodies of those who control power to the norm and considers all the other bodies as abnormal. It therefore forces bodies that are categorized as abnormal to exert extra energy and effort in order to match the expectations of society, and in so doing those bodies inflict harm upon themselves. A famous example is that of John Henryism. ${ }^{5}$ To be sure, John Henryism is "prolonged, high-effort coping with difficult psychological stressors" (James et al. 1987). John Henryism issues from the feeling of worthlessness and the rather superhuman effort to prove one's humanity to those who are ill-disposed to accept that.

Ijeoma discerns an absence of self-worth in the way the women around her see themselves and the women's superhuman effort to make themselves appealing to their society. Her mother is the most obvious example, besides, of course, Amina. Her mother urges Ijeoma to quickly find herself a husband because "a woman without a man is hardly a woman at all" (Okparanta 2015:181). When her mother repeats these words in less than ten minutes, Ijeoma observes that "there was something self-deprecating about the way she said it" (182). Ijeoma understands that her mother is unconsciously subsuming the flourishing of women's bodies within the dictates of patriarchal norms and therefore making them amenable to violation. Insofar as Ijeoma does not disown men entirely, she seems to suggest that it should be possible for women to exercise their freedom regarding the form of life they want to live. This choice is all the more expedient if their sexual orientation is not turned toward men. This is obviously the case with Ijeoma. It should be possible for her to be happy outside the patronage of men and she is not alone in this feeling. There are many more women whose flourishing is not eternally tied to men as pleasure-givers and the ultimate guarantors of happiness in life. They do not have to deny their own self-esteem in order to meet society's expectation. Yet society constricts their being with mores and mythologies.

After the demise of her love with Amina, Ijeoma falls in love with Ndidi, another young woman in Aba, when she returns and helps her mother in her shop. It is in the shop that Ijeoma meets Ndidi in whose eyes Ijeoma sees some warmth and affection. Ndidi initiates Ijeoma into a secret group of lesbians who meet in a church building that is ironically called "FRIENDS IN JESUS CHURCH OF GOD" (190). Ijeoma is also haunted by dreams. Her psyche is, after all, not entirely impervious to society's normativity. Shortly after Ndidi had introduced her to the lesbian club and after she had fallen 
in love with Ndidi, memories of her Bible class with her mother sweep back to her and she thinks of "condemning words falling upon my consciousness like a rainstorm, drenching me and threatening to drown me out" (195). Then she has a dream in which her mother hollers at her, admonishing her that she would eventually perish if she doesn't comply with the demands of the social order. Indeed, soon enough, Ijeoma learns about how precarious the lives of gay people are. Ndidi tells her of an incident in which two "sissies" - the name they called themselves - were beaten to death by two homophobic men. The police's response to the call for help is revealing: "Let them rot like the faggots they are" (205). ${ }^{6}$ Not long after the story, bandits raid the church house where the sissies are having a party. They catch Adanna, one of the sissies, and burn her to death.

Lynching and public shaming are just the more spectacular forms of violence against bodies that fall outside the norm. Gust A. Yep (2017) discusses the individual and collective pain and anguish produced by non-normativity, that is, not being part of the norm. These forms of anguish include isolation, feelings of worthlessness, and shame. In patriarchal societies, where sexuality is conceived in heteronormative terms, the pain experienced by those whose sexuality is not accommodated by this definition is not considered worth paying attention to precisely because their pain is not in the range of authorized experiences; it is considered a result of deviant behavior and is therefore deemed to be self-inflicted. Heteronormativity is the "process that allows heterosexuality to become 'the standard for legitimate, authentic, prescriptive, and ruling social, cultural, and sexual arrangements' in a given society at a particular sociohistorical and geopolitical moment" (116). Heteronormativity has become a "shorthand for the numerous ways in which heterosexual privilege is woven into the fabric of social life, pervasively and insidiously ordering everyday existence" (Lloyd 2013:822). In the heteronormative schema:

gender is conceptualized as naturally following sex (conceived as a natural substance) and desire is conceptualized as naturally following gender (where maleness entails masculinity and masculinity is expressed through sexual desire for the "opposite" sex [i.e., a woman] and femaleness entails femininity, which is expressed through sexual desire for its "opposite" [i.e., man].

(Yep 2017:116)

There is therefore an essential connection between sex, gender, and sexual desire. Anything outside this traditional understanding is seen as abnormal and thus must be contained. Violence consists in this compulsion to contain the unusual, and this compulsion is typically justified by invoking higher authority such as God, morality, and social order. Moya Lloyd (2013:819) characterizes heteronormative violence as that which "constitutes and regulates bodies according to conventional notions of sex, gender and sexuality." Although physical violence is easily recognized as violence per se because 
of the spectacle involved, normative violence, which is intended to compel through pain and terror that people live in a certain way that is contrary to their identity and happiness, is also a form of human rights abuse. ${ }^{7}$

I have argued that human rights abuses ought to be seen in other ways than the widely known forms that attract people's attention. Human rights must also be seen in the microcosmic forms of people's well-being. Ijeoma experiences this muted form of violence firsthand when she succumbs to the sociocultural pressures of her society and marries Chibundu, a man for whom she has no sexual attraction. Her heart and feelings are with Ndidi and that relationship is where her flourishing is located, so when society denies it to her, it goes directly against her well-being. The thought of her having a child with Chibundu gives her nightmares. She thinks of a child that was born deformed and wonders what will happen to it.

The thoughts on the deformed child is a reflection of her condition in her society as a malformed body, a body that had been stifled because of its difference. She sees her condition reflected in all vulnerable bodies. There is no way she can escape her marriage to Chibundu. His society has no alternatives to the form of life her mother had envisaged for her. Ijeoma has therefore to invent means of personal survival. She imagines herself as a "snail protected by its hard shell. Imagine a snail when it is alarmed. Imagine the snail retreating into its shell" (Okparanta 2015:234). Probably feeling the effects of pregnancy, she tells her mother that she has the feeling of being trapped in her body (243). Even when she gives birth to Chidimma, her daughter, she sees the girl as predator and herself as its prey to be eaten alive for the supposed benefit of society. In this regard, therefore, she sees herself as a means to society's end.

As if to drive his society's programmed violence on Ijeoma, Chibundu firmly lets her know that he is disappointed that their child is a girl. He had anticipated a boy and had even chosen a name for him (273). His preference for boys, predicated on their position as heirs to their fathers' estates, adds to the social and cultural power construction that confers legitimacy on some bodies while condemning others. Chibundu's disappointment can be understood within a power structure that sees women only as a means to society's goal of procreation and for men to have heirs. Chibundu does not see any dignity in girls, and surely not in Ijeoma, his wife.

It is, of course, not surprising that Chibundu wants a male heir. Girls cannot inherit their father's estates. Girls and women cannot own anything because they are to be owned. He even goes on to demonstrate to Ijeoma how her existence is entirely dependent on his. There is no better opportunity to display his ownership of her body than when he intercepts a love letter written by Ndidi. He tells Ijeoma in a patronizing, superficially merciful manner:

You can even continue to write to her. But don't you forget for one moment—not for one tiny moment—-that you are $m y$ wife. You are $m y$ 
wife, for God's sake. I can do things to make your life miserable. Do you hear me? You are my wife. Whatever you do, don't provoke me, or I will see to it that you pay the price.

Chibundu's audacity is designed to demonstrate to Ijeoma that she has no rights - not as a woman and certainly not as a lesbian. She hears this in Chibundu's emphasis of the possessive pronoun, $m y$. His threat is an indication that the possessive pronoun is not meant to be mutual as might be the case in a regular couple. Ijeoma is his property. Later on, as she lies in bed and ponders the encounter, she thinks she had become "the equivalent of a washrag, worn and limp, not from overuse, but rather from misuse and manhandling" (284). She is a surplus body. Strictly speaking, though, Chibundu's source of anxiety lies elsewhere; he is losing his position as a master and the norm giver. He feels his existence threatened by the fact that Ijeoma does not need him sexually. Second, he believes that his lineage would cease because of the absence of a male heir. From his perspective, justice is a zero-sum game; he sees the dignity of his position - the husband/master - as sustainable only by the other person's - wife/slave - subordination, servitude, and, finally, indignity.

South African scholar Kopana Ratele (2011:401) argues that female samesex desire generates confusion in the patriarchal imagination primarily because it deconstructs the paradigm of male desire and renders male authority and utility redundant. He states: "without understanding the psychological 'disorder' and social distress that female same-sex sexuality generates in the ruling African masculinity, we would almost certainly misperceive what it means to be a man in today's Africa." Ratele's profound observation about African male sexual desire supports Adrienne Rich's (1993:227-254) notion of "compulsory heterosexuality." In "Compulsory Heterosexuality and Lesbian Existence," she states:

It seems more probable that men really fear not that they will have women's sexual appetite forced on them or that women want to smother and devour them, but that women could be indifferent to them altogether, that men could be allowed sexual and emotional - and therefore economic - access to women only on women's terms, otherwise being left on the periphery of the matrix.

Men are fixated on maintaining the social order that assures their position as masters. They must desire; it is in this compulsion that power and control reside.

\section{Restoring the dignity of difference}

When Ijeoma realizes her complete vulnerability as a female body in a patriarchal, sexist society, she has no place to go and no force to rely on than 
on her God. She prays: "Dear God, I am unhappy. Even as I carry my child, and even as the thought of this child makes me happy, I am yet unhappy. Dear God, I want to be happy" (Okparanta 2015:256-257). This prayer underscores not only the fact that she has been entirely honest to herself about her feelings; it is also a plea for the world to empathize with her. She feels like a stranger in her body. Her body does not belong to her. It is wasting, and it is so because it has been subjected to the aggressions of the system. She has to save herself from wasting. She dreams that her daughter is tied to an Udala tree with her legs hanging. Chidimma holds her father's tiny Bible in her hand. Ijeoma cannot hear what she was reading (310-312).

Ijeoma interprets the dream in line with her experience of bondage and her desire to free herself. It is to be noted that one of the last places Ijeoma saw Amina was under an Udala tree and that was right after Amina had announced she was marrying a man from her ethnicity. She remembers the legend of Udala tree-that spirit children lived in the tree waiting to settle in the wombs of "exceptionally fertile female who comes and stays, for even a briefest period of time, under any of the trees" (309). The Udala tree therefore becomes a symbol of femininity and female subjection to the patriarchal order. Ijeoma knows that Amina was not being true to her being, but she had to conform to the norms of society. Thinking about her daughter in the same position as Amina becomes too much for her to bear, as is the thought of seeing her daughter go through the kind of hardship she herself underwent. She packs up her things and leaves her husband's house, determined never to return. She has to break the cycle of women's self-deprecation and self-denial. Close to her mother's house she sits under the Iroko tree thinking about how her mother would receive the news. Attention is drawn to the difference between Udala and Iroko trees. The Iroko is admired in many African cultures for its imposing structure and durability. Ijeoma turns her back on the Udala tree that symbolizes her solely utilitarian value in society as a woman and embraces the tall, self-assertive Iroko. Luckily for her, her mother finally accepts her the way she is. Her mother's acceptance of Ijeoma's sexual orientation is underlined by a reference to God. "God, who created you, must have known what He did" (323).

In Ijeoma's self-affirmation, Okparanta returns attention to the inherent dignity of every individual. Earlier on, Ijeoma had noted how women subjected themselves to self-deprecation by believing that their worth is essentially dependent on men (182). She now understands that the only way to reverse that is not to seek to change society, but rather to affirm herself. Although all humans possess dignity by the mere fact of being human, that dignity is only fully realized from the moment individuals affirm themselves and seek to protect and preserve who they are.

As I argued in Chapter 1, the moral understanding conveyed by literature is rooted in our imaginative reconstruction of the experience of others. In so doing, we literally become part of that life, that is, by the sheer force of narration, now part of our knowledge-world. I recalled Mark Johnson's 
(1993:x) argument that moral reasoning is basically an imaginative activity because it "requires imagination to discern what is morally relevant in situations, to understand, empathetically, how others experience things, and to envision the full range of possibilities open to us in a particular case." The narratives we have considered in this chapter achieve at least one goal: They present the people of alternative sexualities as ordinary human beings that they are. They are not ogres, and they pose no threat to people and society. Their narratives allow us to encounter them, see them as having moral dimensions and deserving of respect, and, in many instances, to have a moral understanding of the world through them.

\section{Notes}

1 We see similar manifestation of ideology in the United States among conservative politicians.

2 Kuchu is a word (plural: kuchus), apparently of Swahili origin, that lesbian, gay, bisexual, transgender, and intersex (LGBTI) Ugandans have minted to describe their identities. https://www.huffpost.com/entry/the-kuchu-beehive.

3 Of course, one could argue that even if it was the story of who they chose to become, they have right to that. As much as that argument stands, one has to take the current African context into consideration. Most Africans are yet to grasp the fact that sexual orientation is not a choice. Until they overcome that hump, the question of choice seems secondary.

4 In the United States, Rolling Stone is a progression publication. This Ugandan publication is ironically the exact opposite of the American version.

5 John Henryism is named after an African American folk hero laborer.

6 To be sure, "sissy" in English-speaking, Western culture is a derogatory term for an effeminate (i.e., stereotypically gay) man and not applied to women.

7 This is, of course, the definition of a "hate crime." What distinguishes it from an apparently identical act is its vindictive or-in the Foucauldian sensedisciplinary intent.

\section{References}

Abalogu, Allwell Onukaogu and Ezechi Onyerionwu. 2009. 21st Century Nigerian Literature: An Introductory Text. Lagos: Kraft Books Limited.

Akuson, Richard. 2019. “Opinion: Nigeria Is a Cold-Blooded Country for Gay Men-I Have the Scars to Prove It.” CNN. https://amp.cnn.com/cnn/2019/04/17/ opinions/nigeria-opinion-lgbt-attack/index.html (Accessed April 28, 2019).

Anzaldua, Gloria. 2012. Borderlands/La Frontera: The New Mestiza. San Francisco, CA: Aunt Lute Books.

Baptiste, Nathalie. 2014. "It's Not Just Uganda: Behind the Christian Right's Onslaught in Africa." The Nation. https://www.thenation.com/article/its-not-justuganda-behind-christian-rights-onslaught-africa/ (Accessed April 30, 2019).

Blake, Mariah. 2014. "Meet the American Pastor behind Uganda's Anti-Gay Crackdown." Mother Jones. https://www.motherjones.com/politics/2014/03/scott-livelyanti-gay-law-uganda/ (Accessed April 30, 2019).

Boutchie, Jessica. 2019. "Globalizing Hatred.” Harvard Political Review. https:// harvardpolitics.com/covers/globalizing-hatred/ (Accessed April 30, 2019). 


\section{Intimate justice, homophobia, human dignity}

Butler, Judith. 1995. "Contingent Foundations," pp. 35-58 in Feminist Contentions: A Philosophical Exchange, edited by Nancy Frasier. Abingdon: Routledge.

Campbell, Joseph. 1988. The Power of Myth. New York. Apostrophe S Productions Inc.

Centre for Laws of the Federation of Nigeria. 2013. "Same Sex Marriage (Prohibition) Act, 2014." https://www.lawnigeria.com/LawsoftheFederation/Same-SexMarriage-Prohibition-Act,-2014.html (Accessed April 28, 2019).

Dunton, Chris. 1989. “'Wheyting be Dat?' The Treatment of Homosexuality in African Literature." Research in African Literatures 20 (3): 422-448.

Dunton, Chris and Mai Palmberg. 1996. Human Rights and Homosexuality in Southern Africa. Uppsala: Nordiska Africa Institutet.

Eze, Chielozona. 2016. Ethics and Human Rights in Contemporary Anglophone Women's Literature. New York: Macmillan Palgrave.

Family Network. No date. http://www.familylife.ug/about/ (Accessed April 30, 2019).

Foucault, Michel. 1978. The History of Sexuality, 1. Translated by R. Hurley. London: Penguin Books.

Gettleman, Jeffrey. 2010. "Americans' Role Seen in Uganda Anti-Gay Push.” New York Times. https://www.nytimes.com/2010/01/04/world/africa/04uganda.html (Accessed April 30, 2019).

Girard, Rene. 1989. The Scapegoat. Baltimore, MD: Johns Hopkins University Press.

Green-Simms, Linsey. 2016. "The Emergent Queer: Homosexuality and Nigerian Fiction in the 21st Century." Research in African Literatures 47 (2): 139-161.

Hoad, Neville. 2007. African Intimacies: Race, Homosexuality, and Globalization. Minnesota: University of Minnesota Press.

Human Rights Watch. 2016. "Nigeria: Harsh Law's Severe Impact on LGBT Community Encourages Widespread Extortion, Violence. Human Rights Watch." https://www.hrw.org/news/2016/10/20/nigeria-harsh-laws-severe-impact-lgbtcommunity.

James, Sherman A., David S. Strogatz, Steven B. Wing, and Diane L. Ramsey. 1987. "Socioeconomic Status, John Henryism, and Hypertension in Blacks and Whites." American Journal of Epidemiology 126 (4): 664-673.

Johnson, Mark. 1993. Moral Imagination. Chicago, IL: The University of Chicago Press, $\mathrm{x}$.

Kaoma, Kapya. 2009a. "The U.S. Christian Right and the Attack on Gays in Africa." Political Research Associates. http://www.publiceye.org/magazine/v24n4/ us-christian-right-attack-on-gays-in-africa.html (Accessed April 30, 2019).

Kaoma, Kapya. 2009b. "Globalizing the Culture Wars: U.S. Conservatives, African Churches, and Homophobia." Political Research Associates. http:// www.politicalresearch.org/2009/12/01/globalizing-the-culture-wars-u-sconservatives-african-churches-homophobia/\#sthash.I86z4M0d.NBKobD4k.dpbs (Accessed April 30, 2019).

Karimi, Faith and Nick Thompson. 2014. "Uganda's President Museveni Signs Controversial Anti-gay Bill into Law." CNN. https://www.cnn.com/2014/02/24/ world/africa/uganda-anti-gay-bill/index.html (Accessed April 29, 2019). The bill made homosexuality punishable by death.

Kuchu Times. 2016. "Nigerian Man Lynched to Death for Being Gay.” Kuchu Times. https://www.kuchutimes.com/2016/03/nigerian-man-lynched-to-death-for-beinggay/ (Accessed June 13, 2019). 
Lloyd, Moya. 2013. "Heteronormativity and/as Violence: The 'Sexing' of Gwen Araujo." Hypatia 28 (4): 818-834.

McClelland, S. I. 2014. "Intimate Justice," in Encyclopedia of Critical Psychology, edited by T. Teo. New York: Springer. https://doi.org/10.1007/978-1-4614-5583-7_522; https://link.springer.com/referenceworkentry/10.1007\%2F978-1-4614-5583-7_522.

Memmi, Albert. 1990. The Colonizer and the Colonized. (Original 1965). Translated by Howard Greenfield. London: Earthscan Publications.

Mutua, Makau. 2011. "Sexual Orientation and Human Rights: Putting Homophobia on Trial," pp. 452-469 in African Sexualities: A Reader, edited by Sylvia Tamala. Cape Town: Pambazuka Press.

Okparanta, Chinelo. 2013. Happiness Like Water. New York: Mariner Books.

Okparanta, Chinelo. 2015. Under the Udala Tree. London: Granta Publications.

Oriogun, Romeo. 2017. Brunel International African Poetry Prize: Winning Poems. http://www.africanpoetryprize.org/winning-poems (Accessed October 23, 2017).

PBS News Hour. 2015. "Gay Nigerians Face Beatings, Harsh Prison Sentences, Even Death.” https://www.youtube.com/watch?v=kAL0B_QuJbo (Accessed April 28, 2019).

Rao, Mythili. 2013. "Chinelo Okparanta: Champion of the Stifled.” Daily Beast. https://www.thedailybeast.com/chinelo-okparanta-champion-of-the-stifled (Accessed May 3, 2019).

Ratele, Kopano. 2011. "Male Sexualities and Masculinities," pp. 399-419 in African Sexualities: A Reader, edited by Sylvia Tamale. Wantage Oxon: Pambazuka Press.

Rich, Adrienne. 1993. "Compulsory Heterosexuality and Lesbian Existence," pp. 227-254 in The Lesbian and Gay Studies Reader, edited by Henry Abelove, Michele Aina Barale, and David M. Halperin. New York: Routledge.

Ricoeur, Paul. 1991. "Life in Quest of Narrative," pp. 20-33 in On Paul Ricoeur: Narrative and Interpretation, edited by David Wood. London: Routledge.

Scarry, Elaine. 1988. The Body in Pain: The Making and Unmaking of the World. New York: Oxford University Press.

Schaffer, Kay and Sidone Smith. 2004. Human Rights and Narrated Lives: The Ethics of Recognition. New York: Palgrave Macmillan.

Slaughter, Joseph. 2007. Human Rights Inc.: The World Novel, Narrative Form and International Law. New York: Fordham University Press.

Soyinka, Wole. 1996. The Interpreters. London: André Deutsch.

Wright, Katherine Fairfax and Manila Zouhali-Worrall. 2013. Call Me Kuchu, https://www.youtube.com/watch? $\mathrm{v}=\mathrm{mKop} 9 \mathrm{pLPuK0.}$

Yep, Gust A. 2017. "Further Notes on Healing from 'The Violence of Heteronormativity in Communication Studies." QED: A Journal in GLBTQ Worldmaking 4 (2): $115-122$.

Young, Iris Marion. 1980. "Throwing Like a Girl: A Phenomenology of Feminine Body Comportment Motility and Spatiality.” Human Studies 3 (2): 137-156. 


\section{Dignity of woman From misogyny to sex-trafficking}

I have sought to demonstrate in the preceding chapter how heteronormativity structures the perception of who deserves dignity and what is deviant in terms of sexual desires in most African patriarchal societies. What I have said of the violence of normative categorization regarding sexual orientation also goes for gender difference. In the thinking of most people in traditional patriarchal societies, dignity is not what every individual possesses by virtue of being human; it is what society confers upon people. As a result, respect for an individual's moral sphere is contingent on the society's sociocultural or religious institutions. One therefore has dignity if one was good, and one was good if one passed the muster set by society. However, the Universal Declaration of Human Rights (UDHR) has a contrary opinion and states that the individual already possesses dignity by the grace of being a human being - and if they have dignity, then they have rights. Dignity is not contingent on moral probity. I have consistently argued from the assumption that dignity is inherent in a person and that each community must provide enabling conditions for the flourishing of individuals regardless of their ethnicity, religious belief, sexual orientation, or any other marker of difference. This chapter enhances my line of thinking with a focus on the most basic and intimate of social structures: that of the relationship between man and woman in marriage. It states that the dignity of woman is simple: She determines what happens to her body in the same way that a man does.

In "Throwing Like a Girl," American philosopher Iris Marion Young (1980:140) argues that patriarchal and sexist societies disable women's bodies. The disability has nothing to do with the inborn capabilities of these bodies; it has everything to do with a "set of structures and conditions which delimit the typical situation of being a woman in a particular society." Some of these disabling structures include norms, expectations of how a woman ought to behave, the traditional role of women, and rules of propriety; they "operate to produce in many women a greater or lesser feeling of incapacity, frustration, and self-consciousness" (144). Eventually, women who are bodily capable of doing things that most men cannot do 
begin to police and censure themselves lest they be seen as improper and deviant. They comport or shrink themselves to the socially desired stature. Young states that:

The culture and society in which the female person dwells defines woman as Other, as the inessential correlate to man, as mere object and immanence. Woman is thereby both culturally and socially denied by the subjectivity, autonomy, and creativity which are definitive of being human and which in patriarchal society are accorded the man.

Young's insightful observation about women in patriarchal and sexist societies helps us frame the lead questions for a proper understanding of the central argument in this chapter. How does the patriarchal order deny women's bodies justice? We can make a provisional, fairly obvious proposition: a system that is designed to enhance a particular form of bodies at the expense of others considers the advantaged bodies as deserving of dignity, and others less so. Those bodies that benefit from the system have no incentive in dismantling it. On the contrary, they exploit the system to their own benefit. If for example a man lives in a system that grants men the permission to marry many wives, he can easily find an excuse to ignore the feelings of his female partner because women do not deserve consideration in the first place. Sadly, this disabling mechanism of society takes place most pronouncedly in the family.

Until recently, scholarship on African literature has focused on postcolonial concerns. Both the literary world and analyses of them have largely been addressed to the center of the empire. The consequence of the "writeback" literary and cultural attention has been the neglect of pressing moral issues that have no direct bearing on the empire. One of the neglected areas has been the condition of women in African societies. The assumption has been that feminism is a Western thing while Africa has far more egregious problems arising from neocolonialism, and until Africa is free, dissipating attention elsewhere could be counterproductive.

African women writers today are no longer ready to take the backseat in matters of moral and existential relevance about them; they no longer docilely accept a system that has no place for their dignity. They alert us to the pain and anguish such arrangements inflict on them and, therefore, on their moral spheres and their dignity. The truth though is that women writers have always believed that their bodies deserved as much care and attention as the national issues that decolonial and postcolonial discourses were concerned with. They have simply not attracted as much ethically informed scholarly attention as they deserve. In this chapter, I consider three novels by women that engage with the situation of women in a manner that provokes introspection and leads to consideration of ordinary virtues-Buchi Emecheta's 
The Joys of Motherhood, Mariama Bâ's So Long a Letter, and Adebayo Adeyemi's Stay With Me. In the belief that the encroachment in people's moral sphere is already a human rights infringement, I pay particular attention to moments when women find their dignity as humans ignored. I conclude the chapter with a discussion of the phenomenon of sex-trafficking as a form of modern-day slavery and therefore an abuse of human rights.

\section{Slavery as a metaphor of the condition of women}

The Joys of Motherhood is a satirical presentation of the condition of women as a means to the goals of patriarchal society's conception of self. In Igbo society in which the story is set, women are not considered to be valuable in themselves; rather, they are so only to the degree they serve society - that is, men. The story is about Nnu Ego's journey into marriage and motherhood: two spheres of life that are thought to convey meaning and fulfillment to Igbo women's lives. She has two successive marriages and is hardly happy in either. The first one collapses because she cannot conceive, whereas her co-wife, the second wife of her husband, does. She eventually abandons that marriage and returns to her father's house. Her second marriage is different. She conceives and bears a child and therefore gains the respect of her world. She goes on to have six children, to whom she dedicates her life, but their world is no longer controlled exclusively by the traditional economy. Her children pursue their own lives, some of them marrying partners of different ethnicities while some leave for overseas. She dies in old age, poor, and abandoned by her children. In the end, the much-touted joys of motherhood turn out to be the sorrows of being a woman in traditional Igbo society.

Emecheta's concern is to present the condition of women in her native patriarchal society, but she is also conscious of the baggage of feminism in the West and African scholars' decolonial politics of the time. She is therefore careful to present nuances in her own brand of feminism, stating that she is a feminist with a small " $\mathrm{f}$ " and is much more occupied with minor details of women's lives than with global issues (Emecheta 1988:173-185). I understand Emecheta's goal to be to expose the environment that makes the abuse of women not only possible but also seemingly inevitable. By refusing to engage in the ideological fights of her time, but rather in what Ndebele has characterized as the "rediscovery of the ordinary," she exposes the conditions that stifle the lives of women in that culture and allows us to judge that world in relation to universal moral frameworks. Literary scholar Maggi Phillips (1994:90) suggests that The Joys of Motherhood illustrates

...the social dead-ends constructed against women caught between the two incompatible value systems of rural Africa and urban colonialism [...] the novel cries out against the construction of Nnu Ego's selfhood ... [it is also] a font for the bitter, yet inviolable "preciousness of life." 
I concur with Phillips's reading of Emecheta as exposing "the social dead-ends" to which women are subjected in traditional Igbo society. Indeed, Emecheta deploys the trope of slavery to explore the fate of women in her narrative. Nnu Ego is the reincarnation of the slave woman, who was buried alive with her owner, Agunwa, the first wife of Agbadi, Nnu Ego's father. Understanding the context of the slave's death can help us analyze the import of the narrative that Emecheta has crafted. It is customary for a slave to be buried with his or her owner so that the owner will not be alone in the next world. When Agunwa is to be buried with all the honors that belong to a "complete woman," that is, a woman who has served her husband well by giving him heirs,

her personal slave was ceremoniously called in a loud voice by the medicine man: she must be laid inside the grave first. A good slave was supposed to jump into the grave willingly, happy to accompany her mistress [i.e., owner]; but this young and beautiful woman did not wish to die yet.

(Emecheta 1979:23)

The slave begs for her life. Agunwa's eldest son is offended and angrily asks,

"So my mother does not even deserve a decent burial? Now we are not to send her slave down with her, just because the girl is beautiful?" So saying, he gave the woman a sharp blow with the head of the cutlass he was carrying. "Go down like a good slave!" he shouted.

Agbadi intervenes, but not to prevent the slave from following her owner into the grave. Instead, he does so to prevent the slave from being humiliated before she willingly joins her owner in the grave. Before she does that she thanks Agbadi for showing some care and promises him to come back to his household. Then another relative of the dead woman "gave her a final blow to the head, and at last she fell into the grave, silenced forever" (23). Ona, Agbadi's mistress who is pregnant at the time of the killing of the slave, gives birth to Nnu Ego, the novel's protagonist, and "it was noticed that there was a lump on her head." The medicine man divined that the "child is the slave woman who died with [Agbadi's] senior wife, Agunwa" (27). It is therefore safe to state that the story is about the second coming of the slave.

Maggi Phillips (1994:94) contends that

Nnu Ego's spiritual companion and guide, an elaborated slave woman chi, enables Emecheta to write two histories in a single character, or, presumably from an Igbo perspective, to tell the story of the complete woman which includes her revenging and yet sympathetic chi.

Nnu Ego is a reincarnation of the slave woman. Sadly, this second coming does not augur well for the women in that culture. The slave does not come 
back to life as anything other than a woman; she comes back to suffer, but in a slightly more "acceptable" format. Her fate is still the same, and she experiences the same suffering, self-sacrifice, and ignominious death. What Nnu Ego and the slave have in common therefore is the ease with which they are disposed of once they have served their purpose, a practice that speaks to their society's conception of them in utilitarian paradigms. Unlike men, women, like slaves, have no independent existence; their existence is contingent upon that of the masters of their world. Nor do they have acknowledged desires; again they are there only to serve the desires of their masters.

Nnu Ego becomes a metaphor for the condition of all women as slaves in a culture whose paradigms are dictated by patriarchal values and the degree to which women are useful. It is therefore not surprising that as soon as her father sets his eye on her shortly after her birth, he declares out of joy, "This child is priceless, more than twenty bags of cowries. I think that should really be her name, because she is a beauty and she is mine. Yes, 'Nnu Ego' twenty bags of cowries" (Emecheta 1979:26). These words might have been uttered in a harmless manner, yet they suggest the subordinate value of the newly born child as a girl. No one could ever make such utterance at the birth of a boy. Boys cannot be measured in monetary terms because their values are innate in them as future men; they are those who attribute value to others and to things. As Louise O'Brien reminds us, "in traditional culture, women are defined firstly by the men in their lives: initially by their fathers, then their husbands, then their sons. They are defined secondly by their sexuality and their maternity" (O'Brien 2001:96). It is, therefore, unsurprising that Agbadi is particularly happy to have transferred his prized commodity intact to Amataokwu, the next owner. He declares his pride in this feat just in the same way he had at Nnu Ego's birth. "My daughter has been found an unspoiled virgin. Her husband's people are here to thank us" (Emecheta 1979:31).

Amataokwu (Nnu Ego's husband) and her people bring kegs of palm wine to express their gratitude to Agbadi for the fact that Nnu Ego has been found to be a virgin by her husband. The ritual surrounding virginity can be seen as a full stamp of ownership by the new husband. Nnu Ego had not "given herself" to another person; that is, she has not exercised the full ownership of her body because, strictly speaking, her body does not belong to her; it belongs to society and the men of the society guard and guide it. The people have a proverb on virginity and the ease of childbearing: "When a woman is virtuous, it is easy for her to conceive" (31). We recall the social function of myth as enforcing social hierarchy (Chapter 3).

Nnu Ego's marriage to and membership in Amataokwu's household is contingent upon her ability to produce children - that is, her ability to act as a channel through which children, especially males, come into the world. She is judged only to the degree that she is useful, first to her father because she will fetch twenty bags of cowries, and second, she will be useful to her husband because she will produce children. Nnu Ego is not seen for her inherent worth as a human being in either. She is, anyhow, a reincarnation of 
a slave. All of this portrays a culture that ties the dignity of women to their utility in society. A woman, like a slave, is worthy of respect only to the degree she fulfills the goals that society has ordained for her.

Chapter 10, "A Man Needs Many Wives," depicts the fate of Nnu Ego as a good slave, since she is, after all, a reincarnated slave woman. Just as a master needs many slaves, so does a man in an African traditional culture need many wives. The chapter documents the climax of Nnu Ego's suffering as her second husband, Nnaife, is set to "inherit" Adaku, the wife of his dead brother. Nnu Ego dreads the prospect of this coming to pass. She "could not believe her eyes when she came home from market one afternoon to see this young woman sitting by their doorstep, with a four-year-old girl sleeping on her knees" (117-118). Nnu Ego is powerless to prevent this humiliating development. Of course, the culture does not see it as humiliation; it sees it as normal, a way of assuring that society functions. Yet, in doing so, it allows no place for the feelings of women as human beings.

Nnu Ego accepts her condition, knowing that her father could not come to her help. He would tell her, "Listen, daughter, I have seven wives of my own. I married three of them, four I inherited on the deaths of relatives. Your mother was only a mistress who refused to marry me" (119). The notion of inheriting a woman is a cultural given in Igbo society. It is harmless considered from the patriarchal perspective because it was instituted for the good of men and society. However, from the perspective of women living in the knowledge that they are transferrable from one man to another without their free consent, it is no less than living in the knowledge that one has no dignity. Perversely, the condition of women created within the parameters of patriarchy is such that some women are grateful to be inherited. Adaku is not perturbed by her fate; she appears happy to be Nnaife's second wife. She even goes on to assure Nnu Ego of her loyalty and cooperation in the new dispensation (Emecheta 1979, 118). In my discussion of Okparanta's Under the Udala Tree in Chapter 5, I noted Ijeoma's observation of the self-deprecation in her mother's desire for her (Ijeoma) to get herself a man because women are nothing without men by their sides. The same strain of self-deprecation can be observed in Adaku's eagerness to be the second wife of Nnaife. However, we must not forget the condition that obligates women to such self-defeatist attitude to life. They had, indeed, already been defeated by the culture that foresees no autonomy for them.

To drive home the indignity surrounding the condition of women in that culture, Emecheta allows us a deeper glimpse in Nnu Ego's feelings, especially when it is time for Nnaife and Adaku to consummate their marriage.

Nnu Ego fought back tears as she prepared her own bed for Nnaife and Adaku. It was a good thing she was determined to play the role of the mature senior wife; she was not going to give herself any heartache when the time came for Adaku to sleep on that bed. 
Yet Nnu Ego does worry, and the obvious sound of the sexual intercourse taking place in the same room unsettles her as it would most people with any self-esteem. "Nnu Ego bit her teeth into her baby's night clothes to prevent herself from screaming" (125).

As Shivaji Sengupta (1996:228) argues, Emecheta is well aware of the link between sexuality and motherhood; for Emecheta, she states, "being a mother should not be the only reason for women's existence.... Emecheta shows how women themselves adopt the ideals of motherhood created by men, fall into their traps, and are eventually destroyed." Besides Nnu Ego's humiliating pain of being in the same room while her co-wife and her husband are having sex, Nnu Ego's judgment of the condition of women in other instances speaks volumes. When she gives birth to twin daughters, she feels inadequate because they are not boys. That incident is an opportunity to ruminate on the condition of women as means to society's end and not as ends in themselves. She asks, "God, when will you create a woman who will be fulfilled in herself, a full human being, not anybody's appendage?" (Emecheta 1979:186).

For the first time in the narrative we get a complete view of Nnu Ego's perception of self as trapped in her gender and her wish that humans of her gender could attain the rights and dignity due to every human being. Seen within the contours of human rights as they have been established by UDHR, Emecheta states her conception of human dignity and autonomy in her protagonist's mouth. Nnu Ego states further: "I am a prisoner of my own flesh and blood. Is it such an enviable position? The men make it look as if we must aspire for children or die" (187). Emecheta has rightly identified the issue with women and human rights in patriarchal and sexist contexts. It is simply that women are not considered as autonomous beings; they are seen only through the prism of utility.

Toward the twilight of her years, Nnu Ego travels back to Ibuza, to her natal home, where she lives alone and without the care of her childrenespecially not her sons. She wanders the village thinking of her sons, who are in America and Canada.

After such wandering on one night, Nnu Ego lay down by the roadside, thinking she had arrived home. She died quietly there with no child to hold her hand and no friend to talk to her. She had never really made many friends, so busy had she been building up her joys as a mother.

Katherine Fishburn (1995:106) makes an illuminating judgment, regarding the feminist thrust of The Joys of Motherhood: "Of all Emecheta's heroines, Nnu Ego seems most capable of generating sympathetic support from Western feminists." I am not sure Emecheta would be happy to learn that her character has attracted sympathetic support from Western feminists. Indeed, she seems to consciously distance herself from the notion that she appeals to Western standards of feminism. 
To be sure, Emecheta's denial of Western feminist influence is fraught with concerns. Fishburn highlights one of the passages that have engendered two divergent interpretations from the author and her characters. At Nnu Ego's death, the villagers say of motherhood, "the joy of being a mother was the joy of giving all to your children" (Emecheta 1979:224). Fishburn wonders whether the villagers' statement isn't "the narrator's ironic commentary on motherhood" (Fishburn 1995:105). Yet Emecheta appears to debunk this in her biography in which she equates the joys of motherhood in the novel with "a beautiful burial" (105). Fishburn's assessment is insightful and accurate, and she captures Emecheta's dilemma about feminism that I have referred to at the beginning of this chapter. In her already cited essay, "Feminism with a Small 'f'!" Emecheta claims that in many cases polygamy can be liberating to the woman, rather than inhibiting her" (Emecheta 1988:179). This position does not add up, especially considering the detailed narration of Nnu Ego's anguish. In her analysis of Emecheta's novel Kehinde, Pauline Ada Uwakwe (1996:399) casts doubt on Emecheta's claim that polygamy could be beneficial to women who live in it. She writes, "If Kehinde is meant to illustrate the positive aspects of polygamy, Emecheta's depiction of the protagonist reveals a tension between her feminism and her allegiance to African culture."

Perhaps, Emechata's hesitancy about feminism has to do with the state of global politics of feminism in the later part of the twentieth century. Emecheta does not want to be at the wrong end of postcolonial politics, and there's no doubt that authors have legitimate right to interpret their world. My reading of The Joys of Motherhood, however, relies on the contexts and the self-assessment of the characters. I take Nnu Ego's words and feelings seriously. I take seriously the contexts of the lives of women whose existence is overdetermined by the structures set up by men and which foresee no dignity for women. As Marie Umeh (1996:xxiv) has rightly observed, "Emecheta's women for the most part are sacrificed at the altar of male-oriented society, and men exploit the sex-gender system to maintain dominance."

The truth is that Nnu Ego's condition appeals to all who have some degree of co-feeling for their fellows. Like Flora Nwapa before her, Emecheta is good at painting the ordinary details of women's lives and allowing them to speak for themselves. Neerja Chand (2005:49) states that "Emecheta's unique contribution to world literature lies in her commitment to the representation of women's life stories in order to draw attention to the problematic of inegalitarian gender and class relations that cut across racial and geographical boundaries." In my judgment though, Emecheta's main contribution lies in exposing the conditions that enable the abuse of women's human rights, by denying them dignity and autonomy. It is not surprising that Emecheta, together with her countrywoman Flora Nwapa, is considered a pioneering feminist writer in Africa. Mariama Bâ rightly belongs to that pioneering group of women writers who are concerned about women's dignity. In the next section, I discuss her engagement with the environment that are inherently inimical to women's dignity and justice. 


\section{Woman in quest for justice}

One of the questions I raised in the preceding section about determining the context of human rights abuse is: who is responsible for the abuse? Whereas Emecheta is very good at painting the picture of the environment of abuse, Mariama Bâ does not hesitate in establishing the agent responsible for the loss of women's dignity and therefore make it difficult for women to experience justice. So Long a Letter is an epistolary novel that recounts the story of Ramatoulaye, whose husband of thirty years marries a younger woman and dies shortly thereafter, leaving Ramatoulaye to deal with the pain of abandonment in poverty. The novel explores the emotional pain and struggle of women living in a polygamous marriage, situating in particular two women, Ramatoulaye and Aissatou, whose husbands married second wives; while Ramatoulaye decides to stay in the marriage, Aissatou divorces her husband. Whereas it is expedient to point out the conditions that militate against women's agency and dignity, of equal importance is the question of how women can assert their dignity. My discussion therefore focuses essentially on the two women's perception of their world and themselves.

In “'A Feminist Just like Us?' Teaching Mariama Bâ's So Long a Letter," John Champagne (1996:30) discusses the novel as, among other things, a feminist novel. "Ramatoulaye's understanding of feminism," he argues, "is particularly indebted to universalist ideology." Omofolabo Ajayi (1997:35) writes: "With her first novel, So Long a Letter, Mariama Bâ achieved a reputation as a writer who adds a strong, unique, and culturally relevant feminist voice to modern African literature." Ada Uzoamaka Azodo (2003) frames So Long a Letter as a pioneer text in African feminist thought, while Gibreel Kamara (2001:213) argues that in Bâ: "Black women do not see Black men as the enemy. In fact, African and African American feminist critics do realize that the issues confronting Africa, including the problems the woman faces, require the efforts of both genders."

Almost all important commentary on Bâ's works highlights their feminist thrust and seems eager to make a fine difference between Bâ and Western feminists, while others underscore Ba's universal appeal. I belong to this latter camp, and my reason for this is rooted in Bâ's humanistic and sophisticated appeal to the thorny issue of women's subjugation. In his perceptive article on Mariama Bâ's works, "One Wife Be for One Man: Mariama Bâ's Doctrine for Matrimony,” J. O. J. Nwachukwu-Agbada (1991:564) makes a strong case that Bâ's concern in her novels is about the "humiliation of women" by the institution of polygyny. "None of her major female characters accepts it, and where it appears some of them do, it is because of the blind alley in which they find themselves - the confines of marriage or the limited opportunities available to them out-side of it." I concur with Nwachukwu-Agbada and argue that Bâ draws attention to indignities visited on women and their general lack of rights; she also suggests how women's rights could be restored. 
A close reading of the novel reveals something unique about Mariama Bâ. She is of course not a feminist in the conventional, radical Western understanding. In many instances, she (Ramatoulaye) seems supportive of conservative institutions that constrict women's autonomy. Yet she is aware of the injustice that women suffer under those institutions. She does not launch a frontal attack on polygamy, and, as Nwachukwu Agbada has stated, she is undeniably against the indignities it subjects women to. Ramatoulaye seems to be particularly stung by the sheer lack of consideration on Modou's part in their marriage. She accuses him of betrayal, of being unfair to her.

With consternation, I measure the extent of Modou's betrayal. His abandonment of his first family (myself and my children) was the outcome of the choice of a new life. He rejected us. He mapped out his future without taking us into account.

(Bâ 1981:9)

Betrayal is a privation, a deviation from what is normal. Ramatoulaye's disappointment is rooted in her self-understanding as deserving of elementary consideration from the person with whom she had shared her most intimate parts of herself: her secrets and her trust. Betrayal of trust might not measure up to what one could call human rights abuses. Indeed, Modou has not done anything that the culture does not permit. That, however, does not diminish Ramatoulaye's feeling of disappointment and of being wronged. On the contrary, it points to a deeper issue rooted in ordinary virtues, in the simple difference between fairness and unfairness.

In the introductory chapter, I discussed Mrs. Eleanor Roosevelt's insistence that we understand human rights as being exercised in places close to where humans live. She asks: "Where, after all, do universal rights begin? In small places, close to home-so close and so small that they cannot be seen on any maps of the world" (Horton 2007). Roosevelt is well aware of the inescapable link between the violation of trust in the intimate environment of the household as in society; she knows that ordinary virtues are prerequisite for universal human rights. We see this link play out on a deeper level in Modou's disregard for Ramatoulaye. He mortgages the house he co-owned with Ramatoulaye in order to secure a bank loan, which he uses to build a new house for the new mother in-law. Ramatoulaye comments: "Although the title deeds of this house bear his name, it is nonetheless our common property, acquired by our joint savings. Insult upon injury!" (Bâ 1981:10). In mortgaging their common house to finance his libidinal fancies, Modou goes against the moral framework that Ramatoulaye had taken for granted in the three decades of their marriage. In secretly marrying the young woman, Binetou, Modou treats Ramatoulaye as readily dispensable. It is instructive that Ramatoulaye is not attacking any established institution. As much as she is not against polygamy, she seems to challenge Modou to first consider her as a person with dignity, or perhaps to put himself in 
her position, before he makes any of his decisions supposedly supported by tradition. She seems to suggest that if the practice of polygamy were to fall apart, it would be brought about by men who value the ordinary virtues in regard to women.

Ramatoulaye poses several questions that underscore the depth of her disappointment. "Was it madness, weakness, irresistible love? What inner confusion led Modou Fall to marry Binetou?" (11). As much as she is concerned about herself as a person with dignity, her questions are directed at their (Ramatoulaye and Modou) common investment, their humanity. She concludes the many questions by revealing a hint of remorse and her own assessment of the state of affairs.

And to think that I loved this man passionately, to think that I gave him thirty years of my life, to think that twelve times over I carried his child. The addition of a rival to my life was not enough for him. In loving someone else, he burned his past, both morally and materially. $\mathrm{He}$ dared to commit such an act of disavowal.

Of critical importance is that Ramatoulaye judges Modou in moral terms and specifically in the standards established by both of them: respect for their common humanity in which they have long invested. Modou's relationship to Ramatoulaye is, indeed, tinged with violence. There is, to be sure, no obvious sign of physical violence, yet Modou has not flinched at pulling all the registers of power and privilege open to him as a man in that society to his advantage and at the detriment of his wife of thirty years. Like Nnu Ego in The Joys of Motherhood, Ramatoulaye becomes a body that has served its purpose and can therefore be easily disposed of. Indeed, the seed of injustice was sown in the system that made it possible for Modou to ignore the pain his actions and decisions inflict on her. Thus, while Bâ recognizes the active agent responsible for the abuse of women's rights, like Emecheta she also exposes the conditions that enable the abuse.

Whereas Ramatoulaye is too restrained to center her argument for dignity on herself, her friend Aissatou is not. When her husband Mawdo marries another woman he expects Aissatou to remain in the marriage, but she does not want to be part of that. She writes her husband a letter that underlines her heightened awareness of herself as a human who would not allow society or any person to infringe upon her dignity. In the last paragraph of the letter she writes, "I am stripping myself of your love, your name. Clothed in my dignity, the only worthy garment, I go my way" (32).

It is significant that Aissatou mentions the word dignity, which she demands from society no more than what she expects from herself. In emphasizing her dignity, she ends the condition that would rob her of her rights. In her, Bâ seems to suggest that she who wants others to become aware of 
her dignity must first of all demand it of herself. This is indeed how Ramatoulaye regains the awareness of her dignity. After the prescribed forty-day period of mourning her husband, some of the men she had known begin to seek her hand in marriage as their second wife. Her deceased husband's elder brother Tamsir wants to assert his authority in inheriting her: "You are my good luck. I shall marry you. I prefer you to the other one [her younger co-wife], too frivolous, too young" (57). By highlighting Tamsir's reference to his luck in inhering her younger brother's wife, Ramatoulaye makes us understand how women are seen in that society, and she appears to take joy in the power that she has discovered. That power lies in her realization that women have agency; they have voice. She does not hold back her feelings from Tamsir:

Ah, yes! Your strategy is to get in before any other suitor, to get in before Mawdo, the faithful friend, who has more qualities than you and who also, according to custom, can inherit the wife. You forget that I have a heart, a mind, that I am not an object to be passed from hand to hand.

What Aissatou calls dignity, Ramatoulaye calls "voice." It is all about the condition that underscores an individual human's autonomy, her right to her body as belonging exclusively to her. This, I think, is the fundamental assumption of human rights, an assumption on which all others rest.

\section{Human rights in the ordinary facts of life}

Ramatoulaye's words about her having a heart and a mind and her not being an object provide a background against which we can understand the plight of the protagonist in Ayobami Adebayo's novel, Stay with Me. Adebayo is a third-generation Nigerian female writer, who, like Chimamanda Ngozi Adichie, Lola Shoneyin, and other better-known contemporary women writers, is called an heir to Emecheta and Mariama Bâ. In Stay with Me (Adebayo 2017) which is set in Nigeria, Akin and Yejide are ostensibly in a loving marriage. Yejide is distressed because of her failure to conceive after years of marriage. Her mother-in-law arranges a new wife for Akin, but he is incapable of consummating the marriage (Yejide does not know this because she has no understanding of sexual intercourse between a man and a woman). Akin then arranges for Dotun, his younger brother, to impregnate her. However, the first two children born as a result of Yejide's liaison with Dotun die in childhood, leaving Yejide racked with guilt over her acts of infidelity. After learning from Dotun that his sexual involvement with her was instigated by Akin, Yejide feels betrayed by Akin. When her third child, Rotimi, becomes sick, Yejide leaves Akin in the belief that her third child, Rotimi, will die too, but she does not die; she survives, and Yejide must then fight to gain her daughter's love and trust. 
Even a casual reading of the story reveals the operative principle in the relationship between persons in that culture as in the others we have considered thus far: Much of it is seen through the prism of instrumentality, and this applies specifically to women. A woman exists to produce children; anything short of that renders her useless. Their abuse is therefore already programmed in the use to which they are put.

The issue of childless marriages has occupied African women's writing from the pioneering work of Flora Nwapa's Efuru (1966) to an early-twentyfirst-century exemplar of Lola Shoneyin, The Secret Lives of Baba Segi's Wives (2010). Childlessness in marriage is seen as a curse; in almost all cases, the woman is thought to be the cause of the issue. My interest in Adebayo's Stay with Me is to the degree that it raises profound ethical questions about the dignity of women in marriage, especially in such instances as childlessness. More pointedly, it is the question of the value of woman's body to her family. Do men and women occupy an equal ethical and political space within a family?

The narrative chronicles series of humiliating incidents that Yejide experiences because her community considers her body to be deficient. As a woman in a patriarchal society, she knows that her body does not possess the same value as her husband's. The inferior position her body occupies allows people to make judgments about it and determine the use to which it must be put. This condition rankles her. She complains, "A number of my in-laws had been in our home previously to discuss the same issue. Discussion being: they talked and I listened while on my knees" (Adebayo 2017:7). Yejide's sarcastic tone is difficult to ignore. In it, she ridicules other people's meddling in her marriage and their claim to know her intimate life better than she does. In denying her freedom of speech, they give her to understand that she has no autonomy and agency.

It helps to consider Martin Buber's notion of an "I-Thou" relationship in order to judge Yejide's condition. Buber differentiates between experience and relation. One experiences the world of things but stands in relation to the world of humans. When we relate to people, we cease to see them through the lens of utility; rather, we begin to understand that they make our existence whole (Buber 1970:50). Relation is not one-way; it is reciprocity, and reciprocity recognizes the dignity of the other. Experience, for Buber, is "remoteness from you," but relation reduces that remoteness (60). If the remoteness between me and you is nullified, there is then the possibility of encounter, which is the basis of actual life and justice (Adebayo 2017:62). In this encounter, the individual, 'I,' could meet the other, Thou, as "my You." The phrase "my You" seeks to present the other, who is otherwise an indifferent "You," as very close to the subjectivity of 'I' so that there is no longer an estranging distance caused by abstractions such as ideology. The result is then the I-Thou rather than the I-It relationship.

The type of relationship that Buber speaks of is obviously lacking in Yejide and Akin's marriage. The reason for that lack is to be sought in the 
contexts or the cultural assumptions that foresee a woman not as a "Thou" in marriage but as an "It," a means that serves her society's teleology. All this while Yejide is seen by her world only through that prism; they therefore do not consider her as possessing subjectivity and dignity. This condition affects Yejide's comportment. She describes the smile she wears when she joins her husband in the sitting room where his people are gathered to talk about her marriage to Akin. It is a smile that says, "Even though you old people know nothing about my marriage, I am delighted, no, ecstatic to hear all the important things you have to say about it. After all, I am a good wife" (8). Her emphasis on her smile alerts the reader to both her desire to speak and the impossibility of doing so. Her sarcastic use of the phrase "good wife" draws attention to the uses to which women are put. A good woman, like a good slave, is one who has no opinion, no desires, and one who serves her society's teleology.

The ultimate humiliation of Yejide's body is that even though the reason for her inability to conceive lies with Akin, she is still viewed as the cause of the problem, and women are paraded before Akin to be made pregnantthat is, to be conferred with meaning, and as a man, Akin is the ultimate dispenser of meaning (read: justice). Since Yejide is "proven" to be unsatisfactory, Akin's mother arranges for a second wife, Funmi. The goal is, of course, to ensure that Akin produces a child, preferably a boy, to carry on the family name. She and Yejide are simply the means to that predetermined end. Ironically, and typically of oppressed people, the condition to which both women have been subjected engenders unfair competition and hatred between them while Akin pretends to be above the fray. In painting these characters who are denied speech by their world, especially in matters relating to their bodies, Adebayo has constructed a microcosm of the political condition of her society in which the privileged and the underprivileged, those who have a voice and the voiceless, exist in parallel universes even within the same spatial economy. This does not of course mean that her narrative is allegorical; it is rather a portrayal of the human condition in a way that initiates an act of interpretive engagement that allows us to determine the possibility of realizing human rights and dignity in that home.

According to tradition, the second wife of a man in a polygamous marriage ingratiates herself to the first wife so that the first wife can create a space for her in the life of their common husband. But each time Funmi seeks to do so, calling Yejide "mother," Yejide finds both of them diminished, and she never hides her contempt for Funmi (30-31). Because Yejide has no social or legal mechanism for fighting the condition that erodes her dignity, she falls back on what she believes is a proven means through which women assert themselves in African patriarchal societies such as hers: "I simply had to get pregnant, as soon as possible, and before Funmi did. It was the only way I could be sure I would stay in Akin's life" (38). Becoming pregnant increases a woman's stake in a man's life and giving birth to a male child doubles her worth as a human being (56). The situation thus reduces 
her to a tool and therefore increases the value and power of the man. The profound ethical issue here is that of dignity and with it, rights. If all humans are equal in dignity, why then is Yejide denied a voice and why is she considered only as a means to an end?

Thus far, in the ordinary practices of the everyday, Adebayo seeks to achieve the political goal of placing individuals at the core of interactions in society and thereby assert that they should be taken as ends, not means. Here, consideration of the feelings of individuals replaces any ideology that is thought to serve society. Eventually, we learn that all this is played out against the background of military coups and political turmoil (94). It is important for our understanding of dignity that Adebayo does not make the spectacle of the military regime the centerpiece of the narrative. Instead, she enables us to raise questions about the society's relationship to its vulnerable, less privileged members. We see the parallel between the denial of dignity and the objectification of life in a society ruled by the military and one rooted in tradition and ruled by abstract principles.

I return to the irony of Yejide abandoning Rotimi in the belief that she, too, would die like the other two children. Adebayo does not intend Yejide to be perceived as just a victim. Yejide consented to an affair with her brother-in-law. She too owes recognition to others. However, the twist in the narrative, in regard to dignity, is that she is given that which she sorely needs but has been denied to others. When she returns to Akin to attend Akin's father's burial, she is shocked to learn that Rotimi, her daughter, is alive; Rotimi draws her into her arms and calls her Moomi, a Yoruba endearment for mother. It is of profound moral significance that Rotimi recognizes her mother in such an endearing format, given that Yejide had abandoned her. Yejide is overwhelmed by the joy of affirmation and recognition (270).

One of the important scenes in Stay with Me is when Rotimi bonds with Akin (222). Akin happily narrates

one morning she (Rotimi) looked up at me one fist between her chin as though she was pondering what she was about to say and said, "Baba." She said it two more times before she went back to sleep, as if she knew that I needed to hear the word again.

This moment of encounter encapsulates the most important ethical insight in Stay with $\mathrm{Me}$. The child with sickle cell anemia does not die; she stays with the man who is not her father and, in calling him father, affirms him, just as he has affirmed her. This mutual affirmation provides us the best example of affirmation of dignity rooted in the ordinary recognition devoid of utilitarian considerations. Both of them confer to each other what Akin and Yejide could not confer to one another. Recognition does not necessarily have a biological basis; it is our admission of our natality and vulnerability and, consequently, our positive response to it. 


\section{From sexism and misogyny to sex-trafficking}

In this chapter, I have concentrated on conditions that deny women's autonomy, which is essential for human rights. My discussion rested on the premise that when people are hindered from making decisions about their lives, their moral spheres are summarily violated. In exposing the conditions that perennially militate against the dignity of women, and make the abuse of their rights self-evident, Buchi Emecheta and Mariana Bâ paved the way for the subsequent generations of women writers to focus on their bodies. I have discussed Abayomi Adebayo as representative of the current generation of women writers who have continued in that tradition.

We recall one of the central premises that underscore my argument in the book: Atrocities that constitute the well-known cases of abuse of human rights do not start with spectacular forms of violence; they all start with some form of gradual disregard for the other, which is nurtured in narratives and are baked in prejudice. There is an easy correlation to draw between patriarchal and sexist attitudes toward women, that is, the attitude that considers them to be disposable on one hand and as commodities in sex-trafficking, on the other. As a way to conclude this chapter, I provide some thoughts on sex-trafficking also as a prolegomenon for future research on sex-trafficking as human rights abuse in Africa.

There has been increasing awareness of the collective degradation of human dignity brought about by the resurgence of slavery. David Batstone (2007), professor of ethics at the University of San Francisco, sheds light on human-trafficking as modern-day slavery in his insightful book, Not for Sale. Also Mirjam van Reisen and Munyaradzi Mawere (2017) provide important information on this heinous form of human rights abuse in their book, Human Trafficking and Trauma in the Digital Era.

Forms of sex slavery have always been in existence in Africa; however, globalization, migration, and the mass impoverishment of the populace have made it easier to transport (trafficking on) people against their will. Sex-trafficking is an aspect of human-trafficking, which the United Nations Office on Drugs and Crimes (United Nations) has defined as

the recruitment, transportation, transfer, harbouring or receipt of persons, by means of the threat or use of force or other forms of coercion, of abduction, of fraud, of deception, of the abuse of power or of a position of vulnerability or of the giving or receiving of payments or benefits to achieve the consent of a person having control over another person, for the purpose of exploitation.

Nigerian legal scholar Ine Nnadi (2013:179) writes that sex-trafficking is "the fastest growing human rights violation in the world today.... In most cases, it involves involuntary servitude and is therefore commonly referred to as modern day slavery." As Taneem Saeed (2015) has observed, "there 
are millions of people across the world who are still subject to slave-like conditions. Trafficking is the biggest and fastest means by which people are exploited and forced into slavery." It is therefore one of the worst cases of human rights abuses and a threat to collective human dignity.

Sex-trafficking is a worldwide epidemic. In Africa, it appears to be more widespread in Nigeria. According to the CNN report, Nigerian women arrive to Italy in their thousands, lured in part, by the promises of Europe as a land of opportunities (Damon et al. 2017). Osita Ogbu reports that in one of the instances of the state interventions, the Nigerian security officers intercepted twelve prominent businessmen suspected of trafficking thirteen Nigerian women for prostitution abroad at Nigeria's Seme border with Benin. It was revealing that approximately

500 of such women were practicing prostitution in Bamako, Mali, while more than 500 others were ... in Burkina Faso. [The women had been tricked into believing they were] "traveling outside the country with promises of lucrative jobs in Europe. Once they leave, their leaders compel them to go into prostitution, ostensibly to fund their journey to Europe. Many of these women never get to the promised destination but are usually abandoned midway.

(Agbu 2003:7)

According to UNESCO (2006) report, "In Nigeria, persons are trafficked for prostitution, to work as domestic servants, bus conductors, and street traders. They are exploited in agricultural work, brass melting, stone digging and scavenging" (UNESCO 27). The report outlines that some of the causes of trafficking include "poverty, war, lack of information, gender inequality and high demand for cheap labor [that] put demographic populations such as women and children at high risk" (UNESCO 25). Other causes of trafficking on girls and women include "traditional community attitudes and practices, which tolerate violence against women" (UNESCO 32) and the "devaluation of women and children's human rights" (UNESCO 33). I am particularly interested in the last of these causes, and I consider them to be of more strategic importance. People hardly abuse what they appreciate. Slavery in America lasted as long as it did precisely because of the modernist racist image of black people as essentially inferior to whites. It is fair to say that the underlining cause of these cases of gross human rights abuse is the low, or near-absence of a sense of dignity. Telling stories about those people could help humanize them and hence make it easier for people to relate with them.

There have been few fictional works dealing specifically with sextrafficking in Africa. Akachi Adimora-Ezeigbo's Trafficked (2008) provides an important beginning for what is hoped to attract attention to sextrafficking in Nigeria. Indeed, the novel has attracted reviews and scholarly attention (Odinye 2018). I have already discussed Chika Unigwe's On Black Sisters' Street as a feminist novel in my book, Ethics and Human Rights in 
Anglophone African Women's Literature. I highlight it here as another significant example of writing on this issue. The story documents the plights of African bodies fleeing pain and extinction. Sisi, Ama, Efe, and Joyce are young women from Nigeria and Sudan. They were lured to Europe not only by the promises of a better life. These women work as prostitutes in Belgium. What their stories have in common is that the disregard for their bodies did not begin right at the point they were sold; it began, to use Eleanor Roosevelt's expression, "in small places, close to home-so close and so small that they cannot be seen on any maps of the world" (Horton 2007).

The human rights situations in Africa is comparable to those in Europe in the eighteenth century, and which prompted responses in literature such as Jean-Jacques Rousseau's Julie or the New Héloïse and Samuel Richardson's Pamela. Those stories, according to Lynn Hunt, inspired Europeans to begin to frame their conception of liberty around the dignity of every human being. I hope that attention to the works of these African women writers can continue to highlight the abuses of women's human rights and bring about greater appreciation of human dignity.

\section{References}

Adebayo, Ayobami. 2017. Stay with Me. Canongate: Edinburgh.

Adimora-Ezeigbo, Akachi. 2008. Trafficked. Lagos: Literamed Publications (Nig.) Ltd.

Agbada, J. O. J. Nwachuchu. 1991. “'One Wife Be for One Man': Mariama Bâ’s Doctrine for Matrimony.” MFS Modern Fiction Studies 37 (3): 561-573.

Agbu, Osita. 2003. "Corruption and Human Trafficking: The Nigerian Case." West Africa Review 4 (1): 1-8.

Ajayi, Omofolabo. 1997. "Negritude, Feminism, and the Quest for Identity: Rereading Mariama Bâ's so Long a Letter.” Women's Studies Quarterly 25 (3/4): 35-52.

Azodo, Ada Uzoamaka. 2003. Emerging Perspectives on Mariama Bâ: Postcolonialism, Feminism, and Postmodernism. Trenton, NJ: Africa World Press.

Bâ, Mariama. 1981. So Long a Letter. Translated by Modupe Bode-Thomas. Halley Court, Oxford: Heinemann.

Batstone, David. 2007. Not for Sale: The Return of the Global Slave Trade-and How We Can Fight It. New York: HarperOne.

Buber, Martin. 1970. I and Thou. New York: Simon Schuster.

Champagne, John. 1996. "A Feminist Just like Us?” Teaching Mariama Bâ's So Long a Letter." College English 58 (1): 22-42.

Chand, Neerja. 2005. Beyond Feminism: Gender Perspectives on Buchi Emecheta. New Delhi: Books Plus.

Damon, Arwa, Brent Swails and Brice Laine. 2017. "The Sex Trafficking Trail from Nigeria to Europe.” CNN. https://www.cnn.com/2017/12/04/africa/nigeria-benincity-sex-trafficking/index.html.

Emecheta, Buchi. 1979. The Joys of Motherhood. New York: George Braziller Inc.

Emecheta, Buchi. 1988. "Feminism with a Small 'f'!," pp. 173-185 in Criticism and Ideology. Second African Writers' Conference, edited by Kirsten Holst Petersen. Uppsala: Scandinavian Institute of African Studies. 
Fishburn, Kathrine. 1995. Reading Buchi Emecheta: Cross-Cultural Conversations. Westport, CT: Greenwood Press.

Horton, Scott. 2007. 'Roosevelt on Human Rights in the Small Places." Harper's Magazine.https://harpers.org/blog//12/roosevelt-on-human-rights-in-the-small-places/.

Kamara, Gibreel M. 2001. "The Feminist Struggle in the Senegalese Novel: Mariama Bâ and Sembene Ousmane." Journal of Black Studies 32 (2): 212-228.

Nnadi, Ine. 2013. "Sex Trafficking and Women-The Nigerian Experience." Journal of Politics and Law 6 (3): 179-188.

Nwapa, Flora. 1966. Efuru. London: Heinemann African Writers Series.

O'Brien, Louise. 2001. "Buchi Emecheta and the 'African Dilemma'." Journal of Commonwealth Literature 36 (2): 95-106.

Odinye, Ifeoma Ezinne. 2018. "Girl-Child" Trafficking and Sex Slavery in African Fiction: An Analysis of Akachi Adimorah-Ezeigbo's Trafficked." Mgbakoigba, Journal of African Studies 7 (2): 39-53.

Phillips, Maggi. 1994. "Engaging Dreams: Alternative Perspectives on Flora Nwapa, Buch Emecheta, Ama Ata Aidoo, Bessie Heads, and Tsitsi Dangarembga's Writing." Research in African Literature. 25 (4): 89-103.

Saeed, Taneem. 2015. "Human Trafficking in Sub Saharan Africa." http://www. untoldstoriesonline.com/human-trafficking-in-sub-saharan-africa/.

Sengupta, Shivaji. 1996. "Desire and The Politics of Control in The Joys of Motherhood and The Family," pp. 227-246 in Emerging Perspectives on Buchi Emecheta, edited by Marie Umeh. Trenton, NJ: Africa World Press, Inc.

Shoneyin, Lola. 2010. The Secret Lives of Baba Segi's Wives. New York: William Morrow.

Umeh, Marie. 1996. Emerging Perspectives on Buchi Emecheta. Trenton, NJ: Africa World Press.

UNESCO. 2006. Policy Paper No 14.2 (E): Human Trafficking in Nigeria. Policy Paper Poverty Series $n^{\circ} 14.2$ (e) Paris.

United Nations. No Date. United Nations Office on Drugs and Crimes. https:// www.unodc.org/unodc/en/human-trafficking/what-is-human-trafficking. html\#What_is_Human_Trafficking.

Uwakwe, Pauline Ada. 1996. "To Ground The Wandering Muse: A Critique of Buchi Emecheta's Feminism," pp. 395-406 in Emerging Perspectives on Buchi Emecheta, edited by Marie Umeh Trenton, NJ: Africa World Press, Inc.

van Reisen, Mirjam, and Munyaradzi Mawere. 2017. Human Trafficking and Trauma in the Digital Era: The Ongoing Tragedy of the Trade in Refugees from Eritrea. Cameroon: Langaa RPCIG.

Young, Iris Marion. 1980. "Throwing Like a Girl: A Phenomenology of Feminine Body Comportment Motility and Spatiality.” Human Studies 3 (2): 137-156. 


\section{Conclusion}

\section{Politics of love and the common good}

In the introductory chapter, I discussed Michael Ignatieff's notion of the ordinary virtues, which, he argues, is a superior alternative to universal human rights campaigns. The idea of universal human rights, he states, has become rather too legalistic, political, and idolatrous. While admitting of the crucial importance of the ordinary virtues, I argued that Ignatieff comes close to suggesting a narrow sympathy, compared to the more expansive forms of solidarity envisaged by Universal Declaration of Human Rights (UDHR). However, his particularistic emotions need not be in contest with the UDHR; both can complement each other. Narratives, I argued, help us to see their compatibility.

Martha Nussbaum's conception of political emotions can help to further provide examples of the complementarity of the ordinary virtues and the ideals of human rights. In Political Emotions: Why Love Matters for Justice (2013), she asks how we can achieve and sustain a decent liberal society that aspires to justice and equal opportunity for all and inspires individuals to sacrifice for the common good. Reflecting on John Rawls's notion of justice, she asks: Even when you get the principles of justice or politics right, how do you get people to follow them? Even the most elevated principles of fairness such as envisaged by Rawls can be reached "by a route that tethers them to the particularistic imagination and to personal love, and these deep roots continue to infuse the principles even when we achieve them" (386). We need enabling emotions to not only glue us to these principles but also make them function for us all. Emotions such as the ones proposed by Ignatieff, in turn, need to be couched in the conceptions of society that go beyond tribal or other parochial interests.

I find it of immense importance that Nussbaum speaks of liberal societies, which, from a twenty-first-century perspective, are necessarily multiethnic and pluralistic. It therefore goes without saying that any virtue thought to contribute to their flourishing must be universal - that is, transcending boundaries and not limited to a particular group. For Nussbaum (2013:378), "any successful nation needs to be able to demand sacrifice for a common good, they had to ask how sacrifice and common effort would be possible in the absence of monarchical coercion." That sacrifice comes in the form 
of love of the nation, or at least the notion of the common good, which that society stands for. To be sure, Nussbaum (382-383) recognizes that such emotions,

are the real emotions of real people: because people are heterogeneous, having different opinions, histories, and personalities, they can be expected to love, mourn, laugh, and strive for justice in specific and personal ways, particularly if their freedom of expression is protected and valued.

Yet love must go beyond oneself at least because of the fact that we all live in societies of interdependent individuals and groups. We must "cultivate the ability to see full and equal humanity in another person, perhaps one of humanity's most difficult and fragile achievements" (3). Of importance in my discussion of Mandela and the South African effort to build a truly liberal society is Nussbaum's notion of cultivation of abilities. Cultivating positive emotions or striving toward virtues that enhance the common good is indeed the ideal, and, as Nussbaum observes, "ideals are real. Even if we don't attain them, they direct our search" (394).

Nussbaum is not prescribing an overarching notion of love given that such prescription is bound to slip into forms of fundamentalism that often characterize nationalism. That love or a political conception that is thought to achieve an "overlapping consensus among people who may have different religions and secular views of life ... had better be thin in certain ways, not making too many controversial claims about what is ultimately worthwhile in life" (392). It is then more important to highlight, as she does, the cultivation of the moral good, a continuous striving toward a society governed by the principles of justice even in the knowledge that our efforts will always be imperfect. For her, "the inner world is relevant to normative assessment, and it makes a difference to our conception of what we should be like as citizens, even where it doesn't make a difference to any actual conduct" (395-396). Nussbaum's notion of the relevance of positive emotions agrees with what Nelson Mandela had sought to inculcate in South Africans when he insisted on the importance of empathy for the new society (Eze 2012). I understand the South African effort to cultivate what Nussbaum calls "a rich inner life of imaginative and emotional effort" (Nussbaum 2013:395) as a good example of the bottom-up approach to human rights and which deploys all the registers of the narrative to build a decent liberal society. This works especially when the notions of the common good and human flourishing form the foundation of imaginative and moral efforts.

\section{Narrating the new society}

Stories about other people achieve at least one thing: They reveal how much we are all related as humans, how much we have in common. We expand the horizon of our humanity to include those whom we do not yet know and even those we might never know. Stories about ourselves assure us that we are alive 
and that we matter. This last idea sums an important aspect of the South African Truth and Reconciliation Commission (TRC). As explained by Abdullah Mohamed Omar, the then South African minister of justice, the TRC was established, among other reasons, to restore "the human and civil dignity" of victims of apartheid by "granting them an opportunity to relate their own accounts of the violations" (Omar n.d.). The underlining assumption here is that to tell is to feel that we belong; it is to feel affirmed by others. The act of telling alone, which assumes a listening ear, assures the narrator that he or she is not alone, which is already a part of the moral expectations of ubuntu.

The TRC is positioned as the exact opposite of the apartheid ideology of dehumanization of the non-white population. Whereas apartheid meant the exclusion of certain humans and the suppression of truth, the TRC meant openness to all humans and to truth. In inaugurating the TRC, Nelson Mandela ushered in a new age of humanity for South Africa. Indeed, the TRC and its signature philosophy of forgiveness and reconciliation is an extension of his goal of creating a decent society and which involved a modicum of self-sacrifice and an act of love. For example, when he was released from prison, he went to the Cape Town Parade, shook hands with F.W. de Klerk and gave an impromptu speech in which he called for reconciliation. This gesture of reaching out and touching his former archenemy surely had a calming effect on a nervous nation that was unsure of the present and its future, and it became a forceful symbol of the nation's pursuit of a decent society, one in which all are invested in the pursuit of the common good.

It must be stated that South Africa has enormous challenges now. The legacy of economic disparity resulting from the land theft and the massive transfer of wealth during the decades of apartheid still lingers and in many instances causes political instability. It does not help that the seven years of Jacob Zuma's government also ignored the plight of the majority South Africans. Nevertheless, it is also true that the TRC established a roadmap for future efforts at peace and conviviality. Thanks to these efforts, South Africa can now boast of one of the most progressive constitutions in the world. It is one of the few countries where human rights are a top priority of government policies and where they have become an integral part of the people's vocabulary. As Kay Schaffer and Sidone Smith (2004:56-57) have observed,

Up until the release of Mandela there was no discourse on human rights that extended to blacks within the country, no history of published or public storytelling in a human rights context, and no public record of the violations of the majority black population's human rights.

To be sure there have been many forms of intervention in the literary sphere, which include poetry, fiction, and autobiographical accounts of human rights abuses in South Africa. Works such as Breyten Breytenbach's The True Confessions of an Albino Terrorist (1985), Athol Fugard's Siswe Bansi Is Dead, J.M. Coetzee's Age of Iron and Waiting for the Barbarians, Nadine 
Gordimer's Burger's Daughter, and many others highlight instances of the abuse of human rights.

The fall of apartheid naturally made it possible for narratives of human rights to emerge. The establishment of the TRC, as a forum for a ritual of public storytelling, was understood as the ultimate gesture of the recognition of the human rights of those whose humanity had never been recognized within the apartheid dispensation. Desmond Tutu has written of his memory of people coming to him testifying to the effect of their having told their story. The final TRC report was able to announce in a celebratory tone:

The public hearings were successful in two major aspects. They met one of the statutory objectives of the Commission, that of "restoring the human and civil dignity of such victims by granting them an opportunity to relate their own accounts of the violations of which they are the victims"; and, together with the public hearings of applications for amnesty, they revealed the extent of gross violations of human rights and made it impossible for South Africans ever again to deny that such violations had indeed taken place.

(Truth and Reconciliation Commission Report n.d.)

Despite the few weaknesses of the ritual of storytelling embedded in the TRC, and despite the fragility of the peace and reconciliation achieved through the processes and Mandela's political will, it is fair to say that the TRC is indeed a great achievement in terms of restoring to the victims of apartheid the sense of their humanity that the apartheid state and the racist construction of humanity had denied them.

Aside from the TRC, there are other human rights narratives, among which include Antjie Krog's Country of My Skull, K. Sello Duiker's The Quiet Violence of Dreams. I have discussed some of them in my already mentioned book, Race, Decolonization, and Global Citizenship in South Africa (Eze 2018). In the remaining part of this concluding chapter, I discuss Pumla Gobodo-Madikizela's memoir, A Human Being Died That Night, which I consider to be a memorialization of the spirit of reconciliation and South Africa's resolve to the common good and to build an open society in which the human rights of every individual are respected.

\section{Touching the leper, touching humanity}

Pumla Gobodo-Madikizela is a clinical psychologist and served as a member of the committee of the TRC. She is a firm believer in forgiveness, and she is devoted to the principles and practice of human rights (Carroll 2003). Her inaugural lecture as a professor at the University of Cape Town, entitled "The 'Face of the Other': Human Dialogue at Solms Delta and the Meaning of Moral Imagination" (Gobodo-Madikizela 2010), underscores her Levinasian-ubuntu moral persuasion. 
A Human Being Died That Night is constructed around interviews with Eugene de Kock, former commander of the infamous Vlakplaas government hit squad, a detested police colonel, torturer, and assassin. "In the South African media, Eugene de Kock has been described as a mass killer, a psychopath known to the public as "Prime Evil'." It is therefore safe to say that he embodies the evils of the past. He is a leper. Yet, he is the one whom Gobodo-Madikizela seeks out, interviews, and touches. My analysis of the memoir centers especially on the moral and political relevance of this gesture of touching evil.

When de Kock concluded his public testimony at the TRC in September 1997, he expressed the wish to meet with the wives of the men he had ordered killed and to do so in private. That wish excited Gobodo-Madikizela's (2003:14) curiosity, and she met with the women to inquire about their meeting with de Kock. "Both women felt that de Kock had communicated to them something he felt deeply and had acknowledge their pain." The women's testimony about de Kock also made Gobodo-Madikizela to find out exactly what had caused "the loss of de Kock's moral humanity" in the first place (15). She was essentially interested in knowing whether de Kock exhibited any vulnerability because, for her, "When violators of human rights allow themselves to be emotionally vulnerable, they are giving others a chance to encounter them as human beings" (16). As she states in an article, "genuine remorse humanizes perpetrators and transforms their evil from the unforgivable into something that can be forgiven" (Gobodo-Madikizela 2002). Her interest in de Kock's story goes to the root and justification for the TRC's preference for restorative rather than retributive justice. Forgiveness restores humanity to both the injured and the injurer. Her memoir is therefore a mimetic gesture of the TRC; she narrativizes forgiveness in order to demonstrate her own journey and unreserved acceptance of the humanity of all. That however meant touching the untouchable, the leper; it is self-overcoming for the sake of the common good.

De Kock stated that talking about his past "was like letting go of his cloak" (Gobodo-Madikizela 2003:17); it was like being naked, being vulnerable, and returning to the original condition of humanity. It was then that Gobodo-Madikizela reached out to him; she touched "his shaking hands." She confesses to having surprised herself by that gesture of reaching out to touch the hand of murderer, a hand that "was clenched, cold, and rigid, as if he were holding back, as if he were holding on to something withering but still vital form of his old self" (32). She is also well aware that she had crossed a line; she had broken taboo, literally defiled herself. She writes:

In touching de Kock's hand I had touched his leprosy, and he seemed to be telling me that, even though I did not realize it at the time, I was from now on infected with the memory of having embraced into my heart the hand that had killed, maimed, and blown up lives. 
Reaching out to touch the hand that killed her people must have appeared as if she was trivializing her people's pain. But she was indeed being true to her people's notion of ubuntu, which believes in the inviolability of the humanity of all and the fact that anyone who abuses any person's human rights goes against the core spirit of ubuntu and humanity. She sees the vulnerability of the other not as a weakness but rather as an open invitation to reach out. When somebody exposes his vulnerability it is as if the person were totally naked in the public. It is then the duty of the morally conscious to clothe him with care. Ironically, the instinct that made her touch de Kock also revealed to her a stunning truth. The side of him she had touched had not been allowed to triumph over the side that made him apartheid's killing machine (34). She shares Nelson Mandela's (1994:609) belief that "No one is born hating another person because of the colour of his skin, or his background, or his religion. People must learn to hate, and if they can learn to hate, they can be taught to love." But of greater importance for her is what the touch means for her.

The scene of Gobodo-Madikizela touching de Kock, I think, is an instinctual reenactment of that unique, globally relevant moment that Mandela shook hands with de Klerk, thus establishing for the whole nation the operative idiom of the new society. On a smaller scale, reaching out to touch others as Gobodo-Madikizela has done is a simple, essential gesture of empathy. Empathy touches the otherwise untouchable part of others because we occupy, if only momentarily and imperfectly, their position in life. To empathize is to draw the other into the common pool of humanity. It is to reach out, to seek to restore, and it is rooted in the belief that the other is not irretrievably lost.

The body places us at the center of the world. From Merleau-Ponty we learn that the body is aware of its existence because it is in relation to other bodies. The body touches because it is being touched; other bodies make ours perceptible (Merleau-Ponty 2013). Bodies know that they exist when other bodies touch them. As Richard Kearney (2006:16) reminds us, "The ancient term for wisdom, sapientia, comes from sapere, to taste. This etymological line speaks legions, reminding us that our deepest knowing is tasting and touching." It is in this respect that we can understand GobodoMadikizela's gesture as the wisdom that undergirds the new society's adoption of forgiveness and reconciliation as political emotions.

\section{The politics of emotions}

Gobodo-Madikizela, like Desmond Tutu and Nelson Mandela, understands the political importance of what she has done in reaching out to touch the moral leper of South African political history. She is signaling to herself, and through her narration to the whole nation, that there are virtues worth pursuing; virtues that are socially and politically necessary so that it is worth touching a leper at the risk of infection. She demonstrates what Nussbaum (2013:395) has called "inner moral effort," which compels us to affirm even those we do not like. "The inner world is relevant to normative 
assessment and it makes a difference to our conception of what we should be like as citizens." Gobodo-Madikizela puts the riches of her emotion to the service of greater cause, one that transcends her. In her, Ignatieff's ordinary virtue meets Nussbaum's overarching quest for a boundary-transcending narrative within a liberal society.

Gobodo-Madikizela knows that her desire to understand de Kock may be

irrelevant for people who do not have to live as a society with their former enemies. But for those whose lives are intertwined with those who have grossly violated human rights, who sometimes even have to live as their neighbors, ignoring the question is not an option.

(Gobodo-Madikizela 2003:15)

It therefore seems that she is as committed to the polity as are many other actors in the post-apartheid search for peace. She makes sure to underline the fact that her gesture toward de Kock is not exclusively altruistic or of a high moral principle. She is concerned with the project of rehumanization, which is best understood within the context of the common good:

The victim in a sense needs forgiveness as part of the process of becoming rehumanized. The victim needs it in order to complete himself or herself and to wrest away from the perpetrator the fiat power to destroy or to spare. It is part of the process of reclaiming self-efficacy. Reciprocating with empathy and forgiveness in the face of a perpetrator's remorse restores to many victims the sense that they are once again capable of effecting a profound difference in the moral community.

It is important that Gobodo-Madikizela is not claiming any moral superiority. Rather, she understands the precarious nature of rebuilding the South African society. Still in the tradition established by Mandela and Tutu, she proposes social interconnectedness, or what Antjie Krog calls "interconnectednesstowards-wholeness," as a means to enhance the common good. To be sure, for Krog (2008:355), interconnectedness-towards-wholeness is

more than just a theoretical knowledge that all things in the world are linked, it means both a mental and physical awareness that one can only "become" who one is, or could be, through the fullness of that which is around one-both physical and metaphysical.

Interconnectedness-towards-wholeness is a process of becoming that is fulfilled in the individual, but only in the presence - physical or spiritual - of others, living or dead. It is actualized in a moral community. GobodoMadikizela's interest in the rehumanization of her former enemy is therefore not a cosmetic gesture; rather it is for the common good, and it indicates her 
belief in political emotions in the manner Nussbaum has mapped out. In her, storytelling becomes both a symbol and a catalyst of political emotions that serve the interest of flourishing communities. It turns out therefore that the notion of the common good and flourishing of all is a potent means to activate participation in the protection of people's human rights.

The recognition of the other's vulnerability and the instinctive gesture to protect him despite this other's abhorrent past goes to the core of the conception of the human dignity and human rights. Dignity is not dependent on one's moral standing; it is dependent on the fact that one is a human being. This understanding pervades the thoughts of human rights articulated in South Africa's constitution and which continues to animate discussions about human rights.

Mandela understood that the legal framework of human rights needs a strong moral foundation to survive and they, in turn, need strong narratives to make them palpable, or to use Gobodo-Madikizela's idiom, touchable. Narratives do not always succeed in making human rights palpable; thankfully they are just some of the ways to keep alive the indispensable task of alerting ourselves to the unquestionable dignity of every human and the duty of all to honor it. Its failure leads to the degradation of humanity itself.

\section{References}

Breytenbach, Breyten. 1985. The True Confessions of an Albino Terrorist. New York: Farrar, Straus and Giroux.

Carroll, Rory. 2003. "I Embraced the Hand That Had Killed and Maimed." https:// www.theguardian.com/world/2003/nov/03/gender.uk.

Eze, Chielozona. 2012. "Nelson Mandela and the Politics of Empathy: Reflections on the Moral Conditions for Conflict Resolutions in Africa." African Conflict \& Peacebuilding Review 2 (1): 122-135.

Eze, Chielozona. 2018. Race, Decolonization, and Global Citizenship in South Africa. Rochester and New York: The University of Rochester Press.

Gobodo-Madikizela, Pumla. 2002. "Remorse, Forgiveness, and Rehumanization: Stories from South Africa.” Journal of Humanistic Psychology 42 (1): 7-32.

Gobodo-Madikizela, Pumla. 2003. A Human being Died That Night. New York: A Mariner Book.

Gobodo-Madikizela, Pumla. 2010. Inaugural Lecture (extracts). https://www. youtube.com/watch?v=JvJ_3GvsmOs (Accessed June 16, 2019).

Kearney, Richard. 2006. "The Wager of Carnal Hermeneutics," pp. 15-56 in Carnal Hermeneutics, edited by Richard Kearney, and Brian Treanor. New York: Fordham University Press.

Krog, Antjie. 2008. "“This Thing Called Reconciliation ...' Forgiveness as Part of an Interconnectedness-towards-Wholeness." South African Journal of Philosophy 27 (4): 353-366.

Mandela, Nelson. 1994. Long Walk to Freedom: The Autobiography of Nelson Mandela. London: Little, Brown Company.

Merlau-Ponty, Maurice. 2013. Phenomenology of Perception. Translated by Donald A. Landes. New York: Routledge. 
Nussbaum, Martha C. 2013. Political Emotions: Why Love Matters for Justice. Cambridge, MA: Harvard University Press.

Omar, Dullah. No date. South African the Minister of Justice. http://www.justice. gov.za/trc/legal/justice.htm (Accessed June 16, 2019).

Schaffer, Kay and Sidone Smith. 2004. Human Rights and Narrated Lives: The Ethics of Recognition. New York: Palgrave Macmillan.

Truth and Reconciliation Commission. No date. TRC Report, volume 5, chapter 1, p. 8 (no 32). 

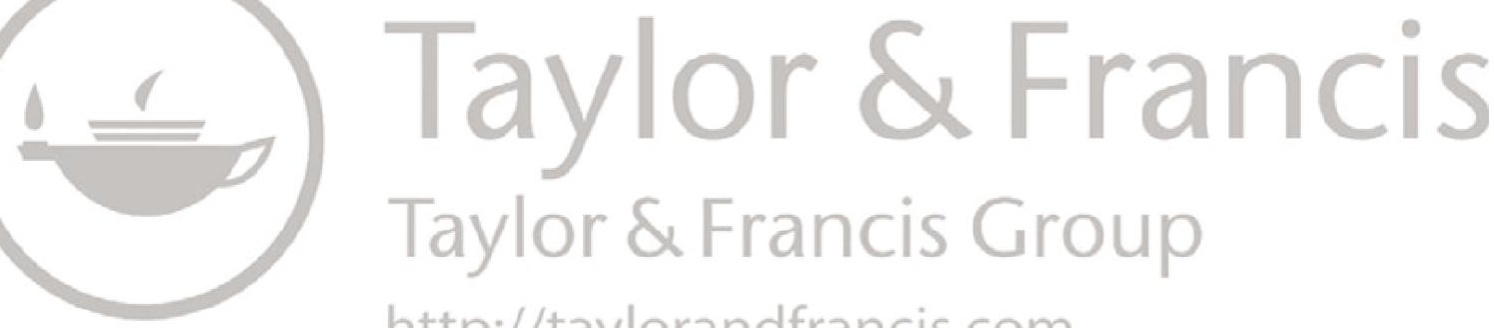

http://taylorandfrancis.com 


\section{Index}

Note: Page numbers followed by " $\mathrm{n}$ " denote endnotes.

Abacha, Sani 52

abuse of difference, uses and 122-127

Achebe, Chinua 122

The Activist (Ojaide) 49

Adebayo, Ayobami 12, 149, 151; Stay with Me 12, 138, 147, 148, 150

Adichie, Chimamanda Ngozi 147

Adimora-Ezeigbo, Akachi:

Trafficked 152

Aesthetic Nervousness (Quayson) 2, 89

African Commission on Human and

Peoples' Rights 31

African patriarchal societies 136, 149

African postcolonial discourse 110

African traditional conception of community 25

Agamben, Giorgio 54, 58; Remnants of Auschwitz: The Witness and the Archive 48

Agary, Kaine: Yellow- Yellow 49

Agbada, Nwachukwu 145

Age of Iron (Coetzee) 157

Agualusa, José Eduardo: The Book of Chameleons 95

Ajayi, Omofolabo 144

Akata Witch (Okorafor) 95

Akuson, Richard 113

albinism 92; in Africa 91; characters with 95; educating people about 98 ; people with 2, 5, 8, 11, 31, 89, 93, 96, 99-101; stigmatization of people with 92,94

albino and recognition 106-107

alternative sexuality $5,31,75,109,110$, $112,113,115,119,133$

American Declaration of Independence 3,30
American Evangelical movement 111

American identity politics 92

Amnesty International 45

Angelou, Maya 120

Anker, Elizabeth S. 30; Fictions of Dignity 5

An-Na'im, Abdullahi Ahmed: Human Rights in Africa: Cross-cultural Perspectives 27

anticolonial writings 5

anti-homosexual zealots 112

Arendt, Hannah 42, 104

Aristotle 9, 20, 22-25, 34n4, 48

Ashforth, Adam 75

Azodo, Ada Uzoamaka 144

Baker, Charlotte 91, 93, 95, 98, 99

Bâ, Mariama 143-147, 151; So Long a Letter 138, 144

Banjul Charter 31

Baptiste, Nathalie 112, 114

Bassey, Nnimmo 11, 49, 60; I Will Not Dance to Your Beat 59

Batstone, David: Not for Sale 151

Because Pula Means Rain (Robson) 95, 99

"The Black Man and Recognition" (Fanon) 106

black people 17, 30, 102; modernist racist of 152; in white skin 90-95

Black Skin, White Masks (Fanon) 96

body normativity 110

Bongmba, Elias 74

Bonhomme, Julien 72

The Book of Chameleons (Agualusa) 95

The Book of Memory (Montagne and Gappah) 95, 102, 104, 105 
Boutchie, Jessica 111

Bremmer, Jan 69

Breytenbach, Breyten: The True

Confessions of an Albino Terrorist 157

Brocco, Giorgio 91-92, 99

Buber, Martin 148

Burger's Daughter (Gordimer) 158

Burke, Kenneth 67

Burns, Robert 50

Butler, Judith 110

"The Call of the River Nun" (Okara) 49-52

Caminero-Santangelo, Byron: Different Shades of Green: African Literature, Environmental Justice, and Political Ecology 47

Campbell, Joseph 68, 127

cannibalism 94, 95, 100

Cassirer, Ernst 67, 68, 80

The Challenge for Africa (Maathai) 40

Champagne, John 144

Chand, Neerja 143

Civil Liberties Organization 52

Clarissa (Richardson) 16

Coetzee, J.M.: Age of Iron 157

The Colonizer and the Colonized (Memmi) 125

Comaroff, Jean 70-73

Comaroff, John L. 70-73

common good 7, 9-12, 17, 21, 24-26, 39, $95,155,156-159,161,162$; justice as element of 27-31; witchcraft and 83-85

"compulsory heterosexuality" 131

Coundouriotis, Eleni 18

Country of My Skull (Krog) 158

cultural philosophy of environment 39-44

"cultural renaissance" 40

cynicism 15

Dalai Lama 43, 44

Dangarembga, Tsitsi 102

Dawes, James 17; The Novel of Human Rights 5

Dibia, Jude: Walking with Shadows 114,120

Didion, Joan 18

Different Shades of Green: African Literature, Environmental Justice, and Political Ecology (CamineroSantangelo) 47

dignity of difference, restoring 131-133 dignity of woman: human rights in ordinary facts of life 147-150; quest for justice 144-147; from sexism and misogyny to sex-trafficking 151-153; slavery as metaphor 138-143

disability: in Africa 2; albinism as 89, 92,136

disposable bodies 128

Donnelly, Jack 27

Douglas, Mary 94

DuBois, W.E.B. 90

Duiker, K. Sello: The Quiet Violence of Dreams 158

Dunbar, Paul Laurence 120, 121

Dunton, Chris 112, 114

Eboiyehi, Friday 72

Eco-critical Literature: Regreening African Landscapes (Okuyade) 47

ecological violence 11, 39, 48, 49; environmentalism 44 47; Niger Delta 47-60; Wangari Maathai and cultural philosophy of environment 39-44

Efuru (Nwapa) 148

Eliot, T.S. 58

Ellison, Marc 78

Ellison, Ralph 120, 121

Emecheta, Buchi 137-139, 141-144, 147, 151; The Joys of Motherhood 12, 138, 142, 143, 146; The Moonlight Bride 95

Emenyonu, Ernest N.: Politics \& Social Justice: African Literature Today 5

empathy $1,5,6,11,16,20,31,33,48,73$, $80,84,85,94,156,160$

environmentalism 37-39, 44-47, 55, 60; criticism 47; degradation 37,42 , 54, 57; devastation 59; pollution 39, 46-47, 52, 60; protection 43, 53

Ethics and Human Rights in Anglophone African Women's Literature (Eze) 10, 152-153

eudaimonia 9, 24, 25

evangelicalism 78,111

evangelical movement 111

Evans-Pritchard, E.E. 64

Family Life Network (FLN) 111

Family Watch International (FWI) 112

Fanon, Frantz 2, 3, 11, 90, 94, 97; Black Skin, White Masks 96; "The Black Man and Recognition" 106; "The Lived Experience of the Black Man" 90; Wretched of the Earth 96 
feminism 137-138, 142-144

Fictions of Dignity (Anker) 5

Fishburn, Katherine 142, 143; The Joys of Motherhood 142

Fisher, Walter 19

FLN see Family Life Network (FLN)

Floode, Isabel 55

Foucault, Michel: The History of Sexuality 110

Frank, Arthur W. 19

Frankfurt, Harry 41

Franklin, Anita 92

Frede, Dorothea 25

Freud, Sigmund 127

Fugard, Athol: Siswe Bansi Is Dead 157

FWI see Family Watch International (FWI)

Gappah, Petina 103, 104, 107; The Book of Memory 95, 102, 104, 105

"gay activities" 112, 113, 115

Gershman, Boris 85

Geschiere, Peter 64, 70, 72-74; The Modernity of Witchcraft in Africa 71

Girard, René 69, 84, 93, 117

Gluckman, Max 65, 66, 70-72

Gobodo-Madikizela, Pumla 160-162; A Human Being Died That Night 12, 158,159

Goldberg, Elizabeth Swanson 8

Golden Boy (Sullivan) 95, 99

Golden Rule 44

Golder, Joe 113

Gordimer, Nadine 157; Burger's Daughter 158

Green Belt Movement 39, 40, 42

Green-Simms, Lindsey 114

Habila, Helon 11, 56, 59; Oil on Water 49,55

Halliwell, Stephen 20

Happiness Like Water (Okparanta) 123

"hate crime" 133n7

Hegel, Wilhelm Gottfried 106

hemorrhagic fever 57

Henryism, John 128

Herder, Gottfried 41

Hernandez, Vittorio 94

heteronormative patriarchy 110

heteronormative violence 110-113, 129

heteronormativity 110, 129, 136

The History of Sexuality (Foucault) 110

Hoad, Neville 114 homophobia 10, 114

homophobic system 128

"homosexual activities" 12, 112

homosexuality 112, 117, 126; and

African literature 113-115, 123; laws against 119

Hong, Esther S. 91

A Human Being Died That Night (Gobodo-Madikizela) 12, 158, 159

human dignity $28,30,31,56,82,142$,

153,162 ; application of 4 ; collective degradation of 151 ; human rights and 117 ; inviolability of 3 ; justice and 5 ; Western notion of 5

human flourishing 1, 5, 9-10, 24, 26, 37, $47,96,121-122,124,156$

human rights $15,16,19-21,28,33,43$, $110,112,117,162$; about human lives 2-6; abuses 29, 56, 57, 64, 73, 78, $80,89,101,113,117,130,144,145$, 152, 157; activist 116; advocacy 33 ; environmentalism and 60; implications 63 ; instantiates 51 ; in ordinary facts of life 147-150; organizations 53; palpable in Africa 31-34; and power of the ordinary virtues 6-9; recognition of 158 ; situation in Africa 17, 153; universal 16, 20, 21, 27, 124, 145, 155; violations 34

Human Rights Council of the United Nations 91, 92

Human Rights in Africa: Cross-cultural Perspectives (An-Na'im) 27

Human Rights in Africa: From the $O A U$ to the African Union (Murray) 27

Human Rights, Inc: The World Novel, Narrative Form, and International Law (Slaughter) 5, 124

human-trafficking 151

Human Trafficking and Trauma in the Digital Era (van Reisen and Mawere) 151

Hunt, Lynn 16, 30, 31, 124, 153

I Am Not a Witch (Rife) 82

Ibhawoh, Bonny 5, 26, 27

Ifowodo, Ogaga 11, 49, 52, 54, 55, 60; Oil on Lamp 52, 53

Ignatieff, Michael 6, 7, 15, 20, 21, 155,161

Iheka, Cajetan: Naturalizing Africa: Ecological Violence, Agency, and Postcolonial Resistance in African Literature 2, 47 
imagined empathy 31

"inner moral effort" 160

"interconnectedness-towards-wholeness" 161

The Interpreters (Soyinka) 95, 113, 114

"In the Omoja River" 52

intimate justice 10,11; homosexuality and African literature 113-115; lyrics of life 119-122; normativity and violence of categorization 128-131; religion, politics, and heteronormative violence 110-113; restoring dignity of difference 131-133; stories and ownership of queer bodies 115-119; uses and abuse of difference 122-127

Iser, Wolfgang 22

I Will Not Dance to Your Beat

(Bassey) 59

Iwunze, Samuel 78

JanMohamed, Abdul 90

Jefferson, Thomas 30

Johnson, Mark 23, 24, 132-133

Johnston, Barbara 37

The Joys of Motherhood (Emecheta) 12, $138,142,143,146$

Julie or the New Héloïse (Rousseau) 16,153

justice 16; about human lives 2-6; abstract notion of 34 ; demand 102-106; as element of common good 27-31; and human rights 2-6; intimate (see intimate justice); narratives and 25 ; and power of ordinary virtues 6-9; primary condition for 83 ; principles of 155,156 ; promotion of 19 ; quest for $39,43,80-82,144-147$; restorative 1 , $6,12,18$; retributive 17,159 ; social 10 , 37 ; writers and 47-60

Kamara, Gibreel 144

Kant, Immanuel 4

Kaoma, Kapya 111, 112

Kato, David 115, 118, 119

Kearney, Richard 160

Ken Saro-Wiwa 49

Khan, Farieda 47

Klerk, F.W. de 157

Kock, Eugene de 159-161

Kramer, Heinrich: Malleus Maleficarum (The Hammer of Witches) 64

Krog, Antjie 161; Country of My Skull 158
Kromberg, Jennifer 91

Kunhiyop, Samuel Waje 77

kwimenya 43

Lama, Dalai 43

Laudato Si: On Care for Our Common Home 37

"law of nature" 113

Leopold, Aldo 48

LGBTQ community $11,12,110$, 113-116, 118-119, 123

The Little Prince (de Saint-Exupéry) 102

"The Lived Experience of the Black Man" (Fanon) 90

Lively, Scott 111-112

Lloyd, Moya 129

Lovén, Anja Ringgren 3, 78

Lund, Patricia 95, 98

Lutzenberger, José 45

Maathai, Wangari 11, 39-44; The Challenge for Africa 40

Male, Moses Solomon 117, 118, 126

Malleus Maleficarum (The Hammer of Witches) (Kramer) 64

Mandela, Nelson 1, 17, 26, 156, 157, 160-162

Mavima, Shingi 103

Mawere, Munyaradzi: Human Trafficking and Trauma in the Digital Era 151

Mbiti, John 64

McCarthy, Joseph 85

McClelland, Sara 110

Memmi, Albert: The Colonizer and the Colonized 125

Merleau-Ponty, Maurice 160

Metz, Thaddeus 26, 106

misogyny 151-153

The Modernity of Witchcraft in Africa (Geschiere) 71

Mohamed Omar, Abdullah 157

Moi, Daniel arap 113

Montagne, Renee: The Book of Memory 95, 102, 104, 105

Month and a Day: A Detention Diary (Saro-Wiwa) 49

The Moonlight Bride (Emecheta) 95

Moore, Alexandra Schultheis 8

Moore, Kathleen Dean 38

moral framework 5, 9, 11, 13n10, 16, 17, $21,27,28,31-34,38,39,44,45,47$, $49,53,55,145$ 
moral order $65-70$

"the morals of religious belief" 113

moral sphere 28, 29, 33, 34, 59, 109, 117, 126, 136-138, 151

Morrison, Donald 24

Movement for the Survival of the Ogoni People (MOSOP) 49

Mpunzi, Thandazile 93

Mswela, Maureen 93, 100

Mugabe, Robert 103, 112, 113

Muhame, Giles 118, 119

Murray, Rachel: Human Rights in Africa: From the OAU to the African Union 27

Museveni, Yoweni 112

Mutua, Makau 114

mythic apprehension of reality 67,77 , $80,89,93$

mythic consciousness $11,63,65-70$, $72-76,80,81,84,101,125,126$

Nancy, Jean-Luc 101

narratives $2,3,9,10,16,20,33,48,49$, $96,103,115,117,124,133,151,155$, 158, 162; African 8, 113; fictional 11; and human rights 25 ; and quest for justice 80-82; traditional 5

Naturalizing Africa: Ecological Violence, Agency, and Postcolonial Resistance in African Literature (Iheka) 2, 47

Ndebele, Njabulo 8, 33, 48, 53, 80, 82; "The Rediscovery of the Ordinary" 32

Nelson, Michael P. 38

neocolonialist machinery 56

Ngong, David T. 66, 67, 70, 74, 83

Nickel, James 28

Niger Delta 47-60

Nigeria 3, 10, 49, 53, 54; albinism 91; banning "homosexual activities" 12 ; Igbo ethnic extraction in 123; laws against homosexuality in 112,119 ; sex-trafficking in 152

Nixon, Rob 38, 44, 46, 48, 49, 53, 54, 57

Nnadi, Ine 151

Nollywood 10, 73-81

Not for Sale (Batstone) 151

The Novel of Human Rights (Dawes) 5

Ntetema, Vicky 2, 89, 91, 101

Nussbaum, Martha C. 20, 156, 160-162; Political Emotions: Why Love Matters for Justice 155

Nwachukwu-Agbada, J.O.J. 144

Nwahunanya, Chinyere 47
Nwapa, Flora 143; Efuru 148

Nyerere, Julius 113

Nyoni, Rungano 81, 82

Obasanjo, Olusegun 53

O'Brien, Louise 140

Odinkalu, Chidi Anselm 30

Ogbu, Osita 152

Oil on Lamp (Ifowodo) 52, 53

Oil on Water (Habila) 49, 55

Ojaide, Tanure 11, 50, 51; The Activist 49

Okara, Gabriel 11; "The Call of the River Nun" 49-52

Okeja, Uchenna 83

Okorafor, Nnedi: Akata Witch 95

Okparanta, Chinelo 122-127, 132; Happiness Like Water 123; Under the Udala Tree 141

Okpewho, Isidore: Tides 49

Okuyade, Ogaga: Eco-critical Literature: Regreening African Landscapes 47

Onazi, Oche 5

On Black Sisters' Street (Unigwe) 152

Onukaogu, Allwell Abalogu 114

Onuzulike, Uchenna 75, 76

Onyerionwu, Ezechi 114

ordinary virtue 1, 6-9, 15-17, 19-24, 27, $29,41-43,56,59,83,137,145,146$, 155,161

"original position" 4

"The Origin of Butterflies" 121

Oriogun, Romeo 120-122

Palmberg, Mai 112

Pamela (Richardson) 16, 153

Phillips, Maggi 138, 139

Political Emotions: Why Love Matters for Justice (Nussbaum) 155

Politics \& Social Justice: African Literature Today (Emenyonu) 5

Pope, Carl 39

pre-industrial African culture 41

primitive belief systems 100

Quayson, Ato: Aesthetic Nervousness 2, 89 queer bodies, stories and ownership of 115-119

The Quiet Violence of Dreams (Duiker) 158

Race, Decolonization, and Global Citizenship in South Africa (Eze) 158

Rao, Mythili 123 
Ratele, Kopana 131

rational choice argument 44

Rawls, John 3, 155

"The Rediscovery of the Ordinary"

(Ndebele) 32

Reisen, Mirjam van: Human Trafficking and Trauma in the Digital Era 151

religious renewal in Africa 111

Remnants of Auschwitz: The Witness and the Archive (Agamben) 48

restorative justice $1,6,12,18$

retributive justice 17,159

Rich, Adrienne 131

Richardson, Samuel 124; Clarissa 16; Pamela 16, 153

Ricoeur, Paul 22, 122

Rife, Katie: I Am Not a Witch 82

"The Right to Culture and the Culture of Rights" (Tamale) 27

Robson, Jenny 96-98, 107n1; Because Pula Means Rain 95, 99

Roosevelt, Eleanor 6, 19, 145, 153

Rothfeld, Becca 102

Rousseau, Jean-Jacques 124; Julie or the New Héloïse 16, 153

Saeed, Taneem 151

Saint-Exupéry, Antoine de: The Little Prince 102

"Same Sex Marriage (Prohibition) Act, 2014" 112

Sartre, Jean-Paul 9, 23, 51, 73, 96

Schaffer, Kay 16, 119, 157

The Secret Lives of Baba Segi's Wives (Shoneyin) 148

self-affirmation 124, 125, 132

self-deprecation 96, 132, 141

Sengupta, Shivaji 142

Sensen, Oliver 4

Senyonjo, Christopher 118

Sethi, Anita 103

sex slavery, forms of 151

sex-trafficking 138; from sexism and misogyny to $151-153$

sexual orientation $115,116,120,125$, $127,128,132,133 \mathrm{n} 3,136$

Shahzad, Khurram 94

Shoneyin, Lola 147; The Secret Lives of Baba Segi's Wives 148

Siswe Bansi Is Dead (Fugard) 157

Slater, Sharon 112

Slaughter, Joseph R.: Human Rights, Inc. The World Novel, Narrative Form, and International Law 5, 124

Slessor, Mary 3 slow violence $38,44,46,48,53-54,56$, 57,59

Smith, Sidone 16, 119, 157

So Long a Letter (Bâ) 138, 144

Soyinka, Wole: The Interpreters 95 , 113,114

spirit of brotherhood 26, 28-29, 34

Stay with Me (Adebayo) 12, 138, 147, 148,150

"stifles African imagination" 74

Stockholm Declaration 37

The Stone Virgins (Vera) 103

Sudnad, Mary 78

Sule, Emmanuel Egya 50, 55

Sullivan, Tara 100, 101; Golden Boy 95, 99

Summers, Lawrence 44, 45, 47, 53, 56

Swanger, David 20

Tamale, Sylvia: "The Right to Culture and the Culture of Rights" 27

"Throwing Like a Girl” (Young) 136

Tides (Okpewho) 49

traditional patriarchal societies 136

Trafficked (Adimora-Ezeigbo) 152

The True Confessions of an Albino Terrorist (Breytenbach) 157

Truth and Reconciliation Commission (TRC) 1, 12, 17-19, 22, 157-159

Tutu, Desmond 1, 17-18, 25, 26, 43, 44, $105,158,160,161$

Ubuntu 9, 19, 25-27, 106, 157, 160

UDHR see Universal Declaration of Human Rights (UDHR)

Uganda 116, 117; American Evangelical movement in 111; banning "homosexual activities" 12; gay activities in 115; laws against homosexuality in 119

Ugor, Paul 76

Ukpabio, Helen 78-80

Umaisha, Sumaila Isah 50

Umeh, Marie 143

Umuntu ngumuntu ngabantu 105, 106

Under the Udala Tree (Okparanta) 123,141

Unigwe, Chika: On Black Sisters' Street 152

United Nations Conference on the Human Environment 37

Universal Declaration of Human Rights (UDHR) 6, 15, 19, 24, 27, 28, 30, 59, 136,155 
universal human rights $16,20,21,27$, $124,145,155$

universal moral framework $8,16,17$, 118,138

U.S. political right 111

Uwakwe, Pauline Ada 143

Ventura, Félix 95

Vera, Yvonne: The Stone Virgins 103 violence: of categorization, normativity and 128-131; ecological (see ecological violence); heteronormative 110-113, 129; against homosexuals 112; slow 38, 44, 46, 48, 53-54, 56, 57,59

Waal, Frans de 84

Walking with Shadows (Dibia) 114, 120
Wildenthal, Lora 29

Williams, Roger Ross 111

Wilson, Monica 70, 84

witchcraft 2, 10, 11, 63, 64, 98; accusation 2, 78, 83-85; and common good 83-85; and modern Africa 71-73; Nollywood, evangelical christianity and 73-80

Wretched of the Earth (Fanon) 96

Wright, Katherine Fairfax 117

Yellow-Yellow (Agary) 49

Yep, Gust A. 129

Young, Iris Marion 128, 137; "Throwing Like a Girl" 136

Zouhali-Worrall, Manila 117

Zuma, Jacob 157 


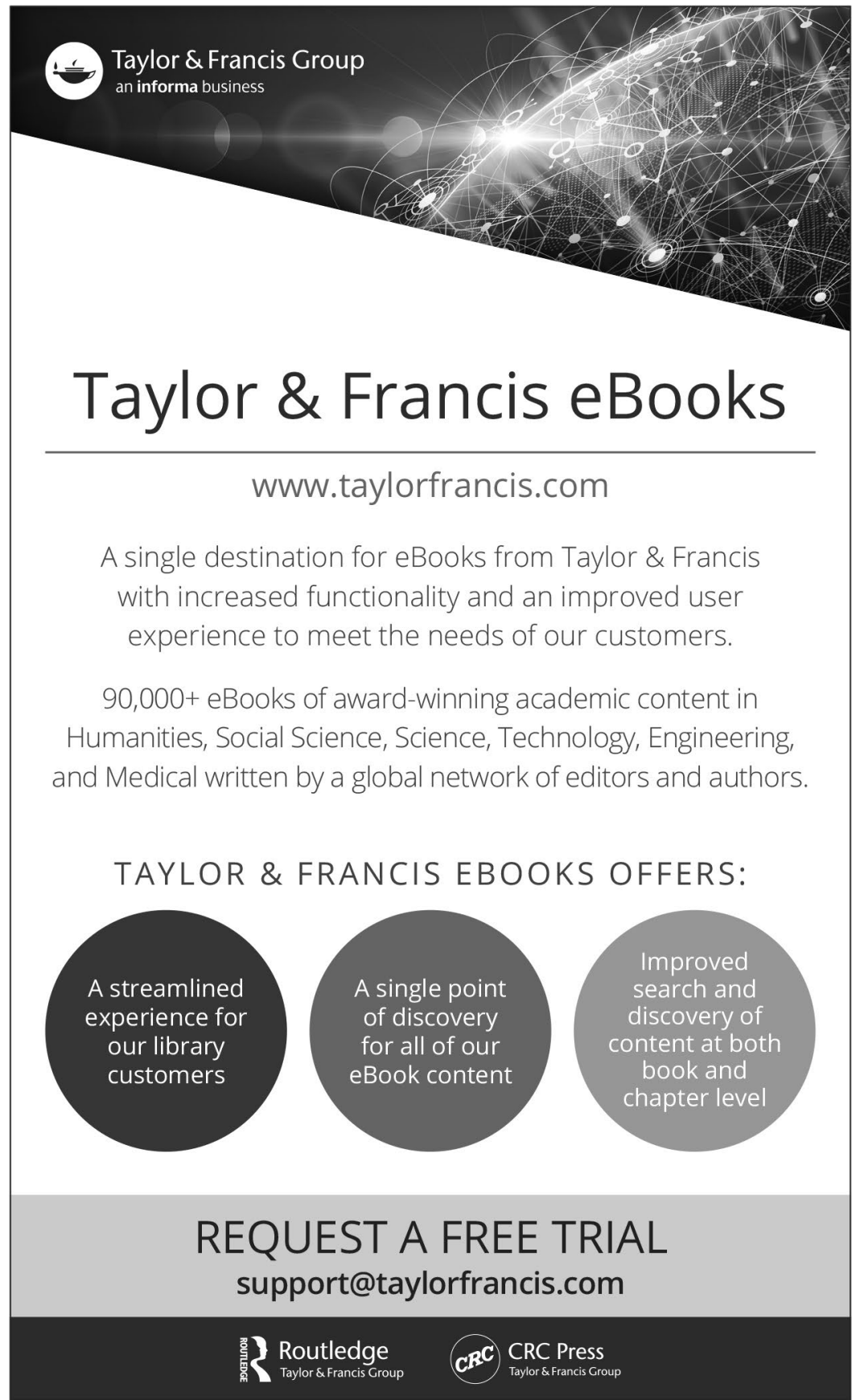

